\title{
Towards in situ chondrogenesis of periosteum : a novel approach for cartilage repair?
}

Citation for published version (APA):

Emans, P. J. (2007). Towards in situ chondrogenesis of periosteum : a novel approach for cartilage repair? [Doctoral Thesis, Maastricht University]. Datawyse / Universitaire Pers Maastricht. https://doi.org/10.26481/dis.20070405pe

Document status and date:

Published: 01/01/2007

DOI:

10.26481/dis.20070405pe

Document Version:

Publisher's PDF, also known as Version of record

\section{Please check the document version of this publication:}

- A submitted manuscript is the version of the article upon submission and before peer-review. There can be important differences between the submitted version and the official published version of record.

People interested in the research are advised to contact the author for the final version of the publication, or visit the DOI to the publisher's website.

- The final author version and the galley proof are versions of the publication after peer review.

- The final published version features the final layout of the paper including the volume, issue and page numbers.

Link to publication

\footnotetext{
General rights rights.

- You may freely distribute the URL identifying the publication in the public portal. please follow below link for the End User Agreement:

www.umlib.nl/taverne-license

Take down policy

If you believe that this document breaches copyright please contact us at:

repository@maastrichtuniversity.nl

providing details and we will investigate your claim.
}

Copyright and moral rights for the publications made accessible in the public portal are retained by the authors and/or other copyright owners and it is a condition of accessing publications that users recognise and abide by the legal requirements associated with these

- Users may download and print one copy of any publication from the public portal for the purpose of private study or research.

- You may not further distribute the material or use it for any profit-making activity or commercial gain

If the publication is distributed under the terms of Article $25 \mathrm{fa}$ of the Dutch Copyright Act, indicated by the "Taverne" license above, 
Towards in situ chondrogenesis of periosteum; a novel approach for cartilage repair? 
Copyright 102007 P.J. Emans

ISBN 978-90-5278-611-7

Layout en druk: Datawyse Maastricht Omslagrealisatie: LCM Jansen 


\section{Towards in situ chondrogenesis of periosteum; \\ a novel approach for cartilage repair?}

\section{Proefschrift}

ter verkrijging van de graad van doctor aan de Universiteit Maastricht, op gezag van Rector Magnificus, Prof. mr. G.P.M.F. Mols volgens het besluit van het College van Decanen in het openbaar te verdedigen op donderdag 5 april 2007 om 16.00 uur door

Peter Joseph Emans

Geboren op 20 september 1974 te Weert

\section{U⿳亠丷⿵冂丶 \\ \begin{tabular}{c} 
UNIVERSITAIRE \\
PERS MAASTRICHT \\
\hline
\end{tabular}}




\section{Promotores}

Prof. dr. R.G.T. Geesink

Prof. dr. S.K. Bulstra, Rijksuniversiteit Groningen

\section{Copromotores}

Dr. R. Kuijer, Rijksuniversiteit Groningen

Dr. L.W. van Rhijn

\section{Beoordelingscommissie}

Prof. dr. ir. L.H. Koole (voorzitter)

Prof. dr. W.B. van den Berg, Universiteit Nijmegen

Prof. dr. H. van Mameren

Dr. G.J. van Osch, Erasmus Universiteit Rotterdam

This thesis was financially supported by:

Nederlandse Orthopaedische Vereniging, Stichting Annafonds, Vygon

Nederland B.V., IsoTis Orthobiologics, Orthopaedie 2000,

GlaxoSmithKline Netherlands, Plus Orthopedics B.V., Somas Orthopaedi

B.V., Bauerfeind Benelux B.V., Ortho Biotech, Livit Orthopedie B.V.,

Zimmer Netherlands B.V.

The study described in this thesis was supported by grant BTS00021 from Senter and by grant LLP14 of the Dutch Reumafonds. 
If the doors of perception were cleansed everything would appear to man as it is: Infinite.

William Blake. 


\section{Content}

Chapter 1: General Introduction 9

Chapter 2: Aims of this thesis 25

Chapter 3: The effects of different decalcification protocols on TUNEL and general cartilage staining

Chapter 4: Variable chondrogenesis of aged human periosteal cells; effects of growth factors on proliferation and differentiation

Chapter 5: Differential cell viability of chondrocytes and progenitor cells in tissue engineered constructs following implantation into osteochondral defects

Chapter 6: In vivo generation of cartilage from periosteum

Chapter 7: A novel in vivo model to study endochondral bone formation; HIF- $1 \alpha$ activation and BMP expression

Chapter 8: Repair of osteochondral defects in rabbits with ectopically produced cartilage

Chapter 9: Summary, Discussion and Future Prospects

Colour figures chapter 3 to 8

Dankwoord

Curriculum Vitae

Publications 


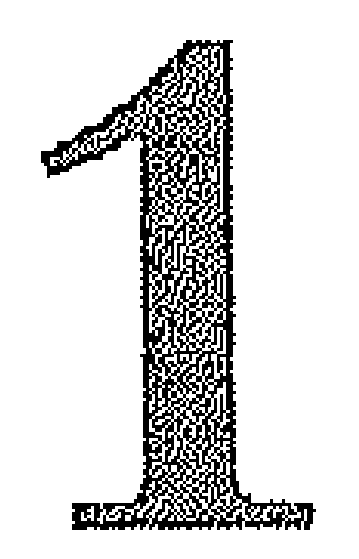

Introduction 
Chapter 1

10

During our life moving, walking, sport, etc. is essential for our health and quality of life. We fully depend on joint motion for these abilities. The presence of healthy articular cartilage is essential for joint motion. Articular cartilage is exposed to an enormous amount of intensive and repetitive forces during life. The wear resistance and friction modus of articular cartilage are unique, however when damaged, cartilage has a limited capacity for regeneration. Articular cartilage lesions which fail to heal spontaneously eventually evolve in osteoarthritis $(\mathrm{OA})^{1-3} \cdot \mathrm{OA}$ is among the most frequent forms of musculoskeletal disorders affecting over $10 \%$ of the adult population ${ }^{4}$. While primary osteoarthritis $(\mathrm{OA})$ is defined as joint degeneration without any underlying cause, in secondary $\mathrm{OA}$ joint degeneration is often caused by trauma (e.g. during sports or in traffic accidents). Traumatic cartilage lesions can be asymptomatic, the percentage of individuals suffering from OA due to a trauma is unknown and may be underestimated. From literature it is known that sixteen to twenty percent of patients with a traumatic hemarthros have a cartilage defect ${ }^{5,6}$, and even up to $60 \%$ of patients undergoing an arthroscopy have a cartilage defect ${ }^{7-9}$.

$\mathrm{OA}$ is a significant socio-economic burden and recent developments for treatment of $O A$ have led to an increasing interest for this affection. Therefore from 2000 to 2010, countries throughout the world, organized in The Bone and Joint Decade organization, have agreed to collaborate in order to improve health-related quality of life for people with musculoskeletal disorders. Understanding the limited capacity of articular cartilage for self-repair and finding new and better methods for treatment of cartilage defects may prevent early OA after traumatic lesions, thus decreasing the incidence of musculoskeletal disorders.

\section{EMBRYOLOGICAL DEVELOPMENT}

Chondrogenesis is a key event in developing limb buds beginning in the center of condensed mesenchyme. The earliest form of cartilage development is suggested to be 300 million years ago ${ }^{10}$. In humans the first rudiments develop during the $5^{\text {th }}$ week of gestation. In the eight week of the embryological life a relatively cell-poor intermediate zone begins to develop. This will form the joint cavity ${ }^{11-13}$. The epiphysis is covered by a vascularized perichondrium and characterized by appositional growth. Interestingly, epiphyseal cartilage lacks a perichondrial layer and interstitial growth is the only form of expansion. Nutrients for the growing epiphyseal cartilage are supplied by two sources; (i) the synovial cavity and (ii) the vascularized cartilage canals ${ }^{14,15}$. Cartilage and 
synovium merge at a transitional zone which persists in the adult and is the site of osteophyte formation.

Bone and cartilage develop from the same mesenchyme, but they have completely different structures, compositions and functions. The diaphyseal cartilage is replaced by bone before birth (primary ossification), most of the cartilaginous epiphysis turns into bone after birth (secondary ossification) leaving cartilage, not covered by a perichondral layer, only at the articulating surfaces of joints. In the adult, bone and overlying articular cartilage are attached by an interface of calcified cartilage ${ }^{16}$. This interface distributes forces and stresses applied during load bearing and acts as a barrier to nutrients.

\section{STUCTURE AND CONTENTS OF ARTICULAR CARTILAGE}

Joint motion is possible by a truly remarkable material both structurally and functionally called hyaline cartilage ${ }^{17-19}$. Different types of cartilage can be found in the human body; (i) hyaline, (ii) elastic and (iii) fibro cartilage. Elastic cartilage is found in the ear and respiratory tract. The menisci and intervertebral discs contain fibrocartilage and hyaline cartilage is predominantly found in articular cartilage.

The chondrocyte is the only cell type found in articular cartilage (Figure 1). In contrast to other tissues, the chondrocyte contributes to a relative low percentage of the cartilage volume (1-5 percent). In adults these chondrocytes lack cell-cell contact. Therefore communication between cells has to occur via the extracellular matrix (ECM). Cartilage is characterized by the absence of blood vessels, lymphatic necessitates and nerve fibers. Chondrocytes receive nutrients and oxygen via diffusion from the synovial fluid through the ECM and from the underlying bone. Their environment is therefore dominated by low oxygen levels and these cells have an anaerobic metabolism ${ }^{16}$. Each chondrocyte is a metabolically active unit which elaborates and maintains the ECM in its immediate vicinity ${ }^{20}$. A high content of proteoglycan aggregates and a relative absence of organized fibrillar collagens is found in the pericellular matrix. These aggregates are bound via hyaluronan to CD44 receptors of chondrocytes. The interaction between hyaluronan and its CD44 receptor is believed to protect the cell against "programmed cell dead" known as apoptosis $^{21-23}$.

Structure. In articular cartilage four zones are discriminated, based on chondrocyte shape and distribution and collagen type II orientation ${ }^{17,18,24}$ (Figure 2). 


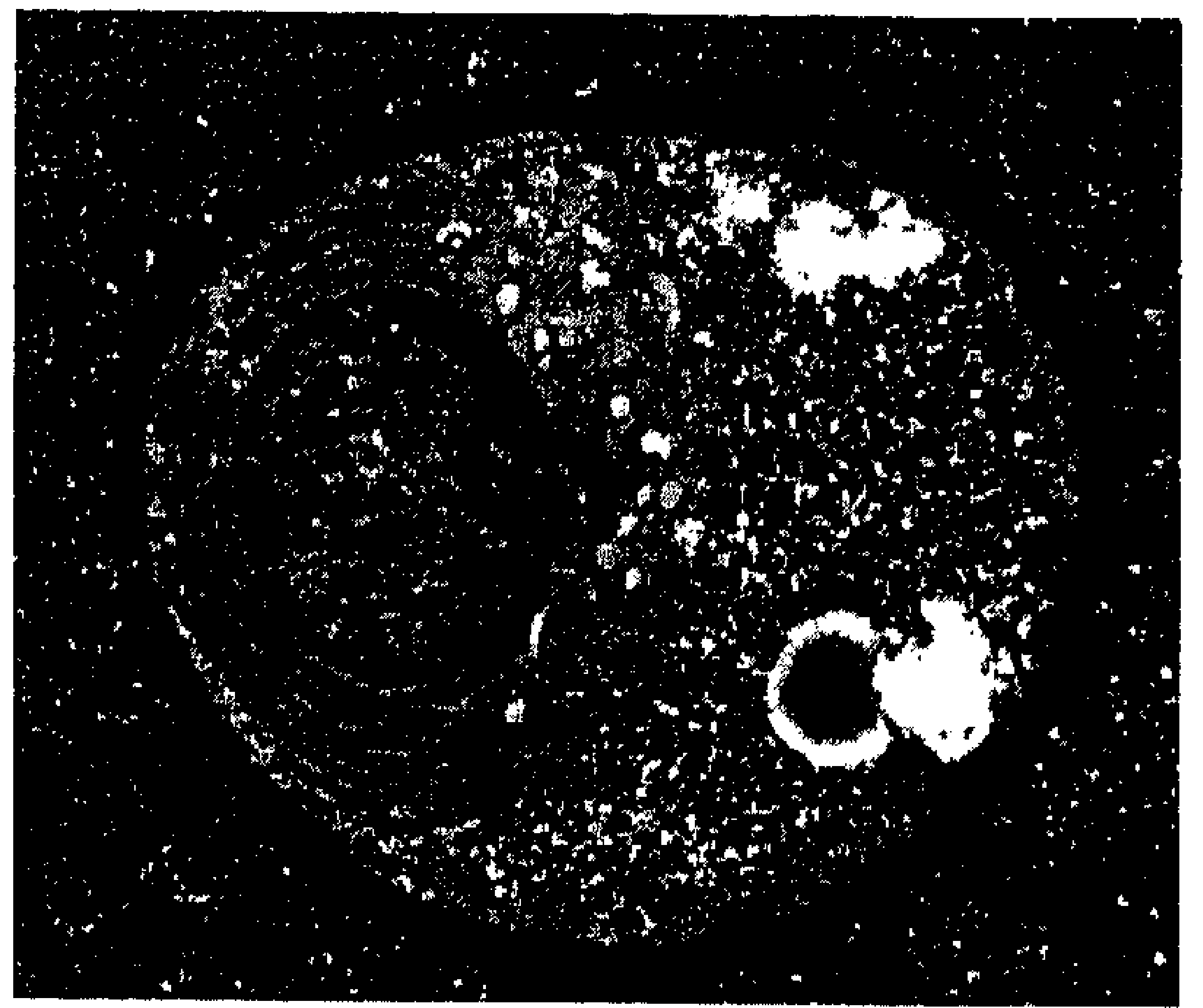

Figure 1: Electron micrograph of a chondrocyte. Reprinted from Archer et al. Int J Biochem Cell Biol. 2003 Apr;35(4):401-4. With permission from Elsevier.

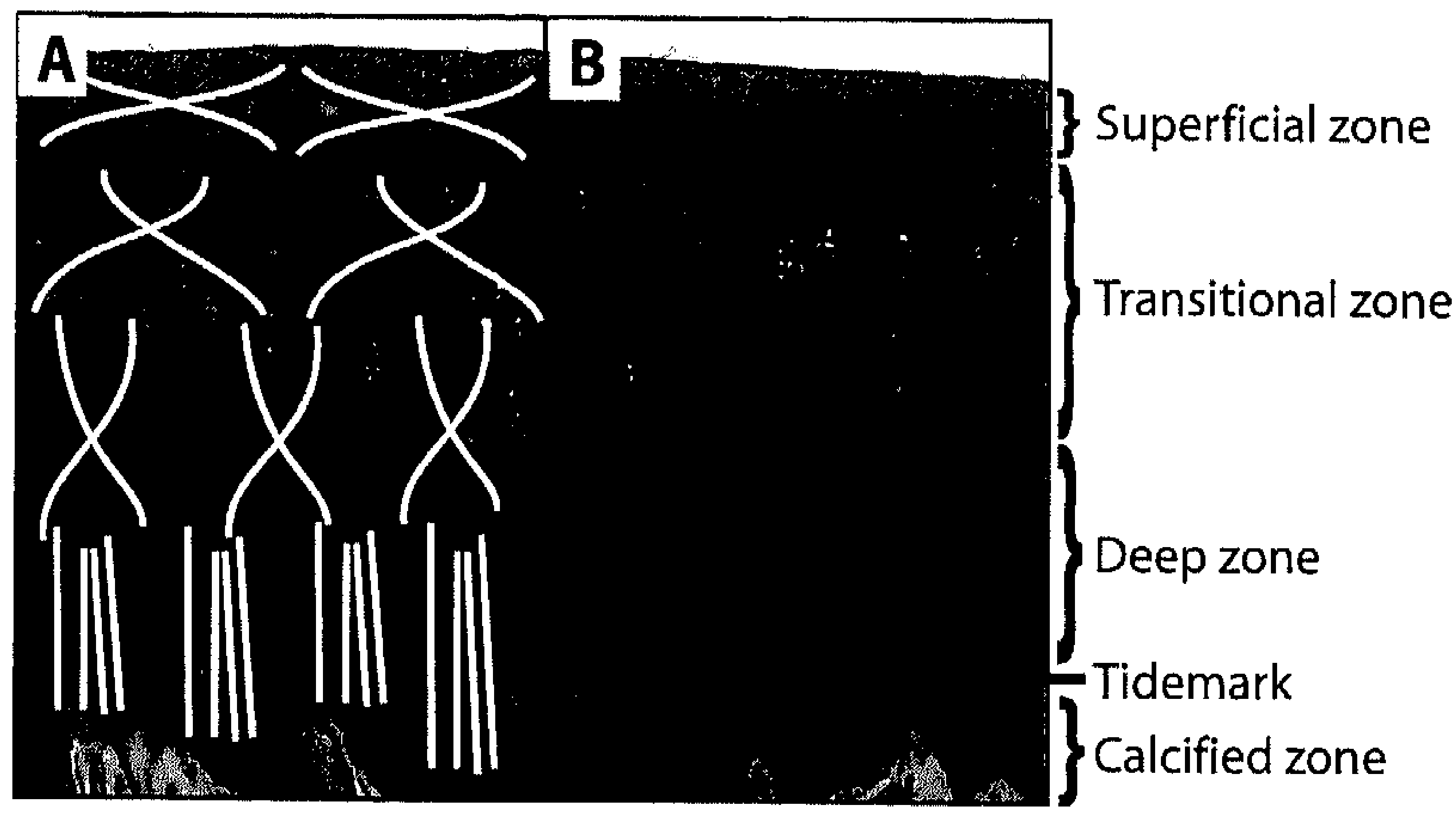

Figure 2: Architecture of articular cartilage. Four zones can be distinguished with respect to (A) orientation of collagen fibers $(B)$ cell shape and orientation.

In the superficial or tangential zone, chondrocytes are disc shaped and form a layer of several cells thick. The long axes of the cells are parallel to the joint surface and the cells are surrounded by a thin layer of ECM. Thin collagen fibers are oriented parallel with the articular surface. This orientation and the relatively low content of proteoglycans results in high tensile stiffness and the ability to distribute load over the surface.

The cells in the transitional or middle zone are more spherical and appear dispersed randomly ${ }^{11,25}$. Collagen fibers in this zone are organized randomly. At this zone and deep zone, high concentrations of proteoglycans enable the tissue to bear compressive forces. 
In the radial or deep zone, chondrocytes are ellipsoid, grouped radially in columns of 2-6 cells with their long axes perpendicular to the joint surface. The thicker collagen fibers are also arranged perpendicular to the articular surface.

In the calcified zone, chondrocytes are distributed sparsely and remain surrounded by a calcified matrix. The calcified cartilage is less stiff than the subchondral bone. At this calcified zone shear stresses are converted into compressive forces which are in turn transmitted to the subchondral bon $\mathrm{e}^{26}$. The junction between uncalcified and calcified cartilage is called the "tidemark", a line which histologically can be seen (Figure 2). Therefore mechanical forces also change at the tidemark which provides a definite boundary for the uncalcified layer ${ }^{11,27}$.

Collagen Type II is the most prominent collagen in cartilage which represents $90 \%$ of collagens found in articular cartilage. Alternative splicing occurs in the Type II Collagen gene. In the procollagen gene exon 2 encodes for a cysteinerich domain in the amino-terminal propeptide which results in a type II $\mathrm{A}$ procollagen $^{28}$. This type IIA is expressed by immature chondrocytes, but is not expressed in mature cartilage. In Collagen type IIB, which is present in mature cartilage exon 2 is spliced out. Collagen type II in mature cartilage is composed of three identical polypeptide chains, $\alpha_{1}$ (II), and belongs to the fibril forming class of collagens (class 1). Collagen Type II is synthesized and secreted as a procollagen precursor whose nonhelical extensions are removed by enzymes. During this process the large $(35 \mathrm{kDa})$ chondrocalcin is released (The Nterminal propeptide). Chondrocalcin concentrations give useful information about Collagen Type II synthesis ${ }^{29}$. Hereafter the trimmed collagen is incorporated into the ECM where it is crosslinked. Within the deep layer of cartilage arcades of thick fibrils are formed whereas in the surface fine fibrils are arranged horizontally ${ }^{16,20}$ (Figure 2A).

Collagen type VI is only found in the pericellular matrix surrounding the chondrocyte ${ }^{30-34}$. The cell surrounded by hyaluronan and the layer of collagen type VI is called a "chondron". Chondrons harbor and protect the chondrocytes from mechanical forces ${ }^{35-37}$. Collagen Type IX belongs to the class 3 short-helix molecules which may function as a connector between Collagen Type II fibers ${ }^{24,38-41}$. Collagen type XI is a class1 (fibril forming) collagen and is coassembled in the heterotypic fibrils of articular cartilage ${ }^{42}$. The average halflife of collagens in articular cartilage is calculated to be 117 years while the average half-life of skin collagens is 15 years $^{43}$.

Aggrecan is the name of an aggregating proteoglycan which consists of a central protein with multiple sulfated glycosaminoglycans (GAG's), especially Ketatan Sulfate and Chondroitine Sulfate, covalently attached to it. The average 


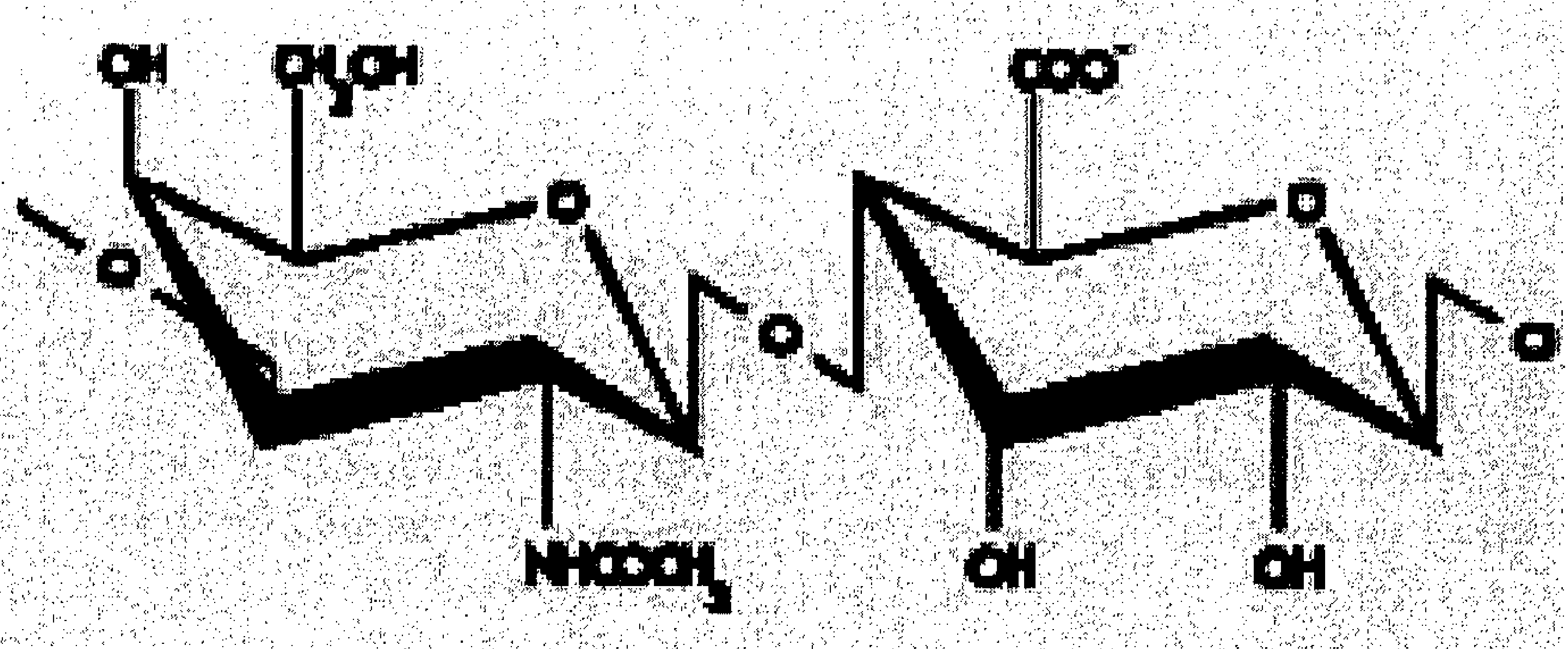

Figure 3: A hyaluronan molecule; consists of alternating glucuronic acid and Nacetylglucosamine units, which is repeated over and over to form long chains. Each repeating disaccharide unit has one carboxylate group, four hydroxyl groups, and an acetamido group.

half live of aggrecan molecules, measured with aspartic acid racemization, is approximately 2 years $^{44}$. However aggrecan half live is different between the zones $^{45,46}$.

Hyaluronan is a long polymer of repeating disaccharides (Figure 3). Aggrecan is bound to this polymer and the bond is stabilized by link protein. The high concentration of anionic charge of the GAG's has important biomechanical features. The negative charges repel each other which results in an expanded state of these large molecules. This expanded state ensures that these matrix molecules remain "captured" in the collagen network.

Anchorin is smaller and is found on the surface of chondrocytes and within the cell membrane. This protein may mediate interactions between the cell and its matrix. Due to its high affinity for type II collagen fibrils, it may act as a mechanoreceptor ${ }^{47}$. Healthy articular cartilage compromises larger aggregating proteoglycans such as aggrecan whereas non-aggregating smaller proteoglycans such a biglycan and decorin are found in small amounts ${ }^{48,49}$.

Water is, to some degree, bound by negative charges of the GAG-chains. Due to this hydrophilic feature of the matrix, cartilage can maintain large amounts of water (up to $80 \%$ wet weight ${ }^{50}$. Extra cellular water can move through the ECM. Compression will lead to "outflow" of water from the ECM. During decompression water will be "re-absorbed" in the matrix. This principle results in the unique capacity of cartilage to absorb and transmit mechanical forces during joint motion and loading. In healthy articular cartilage the water binding 
capacity of aggrecan is only used for about $20 \%$ due to the restriction in swelling by the collagen network.

\section{PERIOSTEUM}

The outer surface of bone is covered by a condensed, fibrocollagenous layer called periosteum. This periosteal layer is attached to the underlying bone by extrinsic collagen fibers. These Sharpey's fibers penetrate deep into the outer cortical tissue. Two layers can be found in periosteum; (i) the outer, thicker fibrous layer, and (ii) the layer adjacent to the bone called the cambium layer (Figure 4). The name "cambium" derives from the cambium layer of a trunk of a tree ${ }^{51,52}$. This cambium layer contains mesenchymal stem cells with osteochondrogenic potential. Periosteum is highly active during fetal development when it generates osteoblasts for the appositional growth of bone. Parathyroidhormone related protein (PTHrP) is expressed by periosteum ${ }^{53}$. Indian Hedgehog and PTHrP are two signaling molecules that interact in a negative feedback loop regulating the pace of hypertrophic differentiation of the chondrocytes in the growth plate, thus growth of long bones is also influenced by periosteum ${ }^{54}$. The thickness and chondrogenic potential of periosteum decreases with age ${ }^{55}$. Periostin is another molecule expressed by periosteum, this adhesion molecule is believed to play a role in the recruitment of osteoblast precursor ${ }^{56}$. Periosteum remains important in fracture healing. Periostin is highly up-regulated during fracture repair at mechanical stress ${ }^{57,58}$. If it is absent, e.g. within the joint capsule of the femoral neck, fractures heal slowly. Removing periosteum surrounding a fracture leads to absence of cartilage in the fracture callus ${ }^{59}$.

\section{TRAUMATIC CARTILAGE DEFECTS}

Whereas the progenitor cells of bone marrow and periosteum contribute to bone formation during fracture healing, articular cartilage is deprived from these progenitors. It has been shown that the superficial layer of cartilage and the synovium contain progenitor cells ${ }^{60,61}$. Although these progenitor cells are present, in contrast to bone, cartilage has a limited ability for self repair ${ }^{2,62}$. As early as 1743 it was recognized that articular cartilage, once destroyed, does not heal spontaneously ${ }^{63,64}$. Damage to the joint surface may lead to premature arthritis ${ }^{3,65}$. 
Diagnosis of cartilage defects. Since cartilage has no nerve fibers, cartilage lesions often present with only (minor) effusion of the affected joint or without symptoms. Diagnosis of structures likely to be damaged upon trauma (e.g. subchondral bone, ligaments or menisci), may reveal a cartilage lesion. An X-ray indicates a cartilage lesion in the minority of the cases and Magnetic Resonance Imaging (MRI) is the best non-invasive technique available for diagnosis of cartilage lesions. Important developments are new protocols such as delayed Gardolinium Enhanced MRI of Cartilage (dGEMRIC) and sodium MRI which can visualize cartilage on a Collagen and GAG content level ${ }^{66}$. Overall the MRI is expected to diagnose cartilage lesions in an early stage and will become more important in evaluation of progression of cartilage degeneration and cartilage repair techniques.

Factors influencing cartilage repair have to be considered for understanding the nature of such lesions and comparing and discussing different options for cartilage repair. Different factors can be distinguished.

Depth of the defect is of importance since, in contrast to chondral defects, the underlying vascularized bone is penetrated in osteochondral defects. In osteochondral defects, mesenchymal stem cells and blood cause a limited repair response ${ }^{63}$. After filling with granulation tissue, these injuries undergo repair with fibro-cartilage ${ }^{67,68}$. Formation of fibrocartilage may relieve symptoms. However, in contrast to hyaline cartilage, fibrocartilage can withstand tension but not repetitive compression forces. In time, this incapacity will lead to degeneration ${ }^{69,70}$.

Chondral defects are partial thickness defects and often fail to heal spontaneously ${ }^{1,71}$. These lesions usually progress to more widespread degeneration that eventually may lead to osteoarthritis ${ }^{3}$. Especially in these defects, the absence of blood vessels and nerve fibers or the inability of chondrocytes to migrate through the tight ECM may be the underlying cause of this poor regenerative capacity ${ }^{72}$. Anti-adhesiveness of reparative cells of the articular cartilage matrix has also been reported to be the underlying cause ${ }^{6.3}$.

Location of the defect influences progression of the lesion. Lesions located in the central region of the medial compartment of the knee are more likely to progress to advanced cartilage degeneration than lesions located anterior and posterior or lesions located in the lateral compartment of the knee. Lesions located in the anterior region of the lateral compartment are the least progressive lesions ${ }^{73}$.

Size of the defect correlates with the healing capacity of the defect; the smaller the defect, the larger the chance of healing ${ }^{74}$. Lesions smaller than a "critical size" defect may heal completely. Lesions larger than this "critical size" 
encounter a limited healing process. The size and definition of a "critical size" defect is different between species. In contrast, Lang et al. have described that no specific grade of lesion identified at baseline had a predilection for more rapid cartilage $\operatorname{loss}^{73}$.

Different animal models are used to study cartilage repair. Cartilage lesions in smaller animals have a better capacity for self repair than lesions in larger animals. Rodents are known to have, especially for osteochondral defects, a better healing response.

The age of the organism is of influence since it is generally accepted that lesions have a decreased repair capacity with an increasing age of the organism. This is in accordance with in vitro models where isolated chondrocytes of immature humans and animals have a greater proliferative capacity and better ability to synthesize new matrix than cells from mature animals and humans.

Anterior Cruciate Ligament (ACL) tears and meniscal tears have a negative effect on cartilage healing. In patients who have sustained a meniscus tear, a higher rate of cartilage loss is observed than in those who have intact menisci. Although not significant, ACL tears show a tendency to increase loss of cartilage as well ${ }^{73}$.

Weight of the patient and alignment of the leg influence the healing of cartilage. Loading forces of cartilage increase with overweight and malalignment. In these situations cartilage repair is negatively influenced since the mechanical demands for the repaired cartilage are much higher and the repaired cartilage may be damaged upon loading.

Continuous passive motion enhances healing of many types of articular cartilage lesions ${ }^{71,75-83}$. In contrast to immobilization using cast or allowing load bearing, continuous passive motion enhances formation of hyaline cartilage in rabbits ${ }^{84}$. Overall the current role of continuous passive motion is accepted to have a beneficial effect when combined with other strategies aimed at cartilage repair e.g. subchondral penetration, periosteal transplantation etc. ${ }^{71,77,79,85}$.

Treatment of damaged cartilage can be grouped to four concepts of principle; the four R's ${ }^{86}$. The joint surface can be; (i) resected, (ii) relieved, (iii) replaced or (iv) restored. A joint prosthesis is an example of joint replacement, joint distraction and osteotomies can induce joint relieve. Osteotomies are used to re-align the axis of loading in patients with a malalignment of the leg. By transferring the load to the less affected cartilage (e.g. previously less loaded/damaged cartilage) the OA part is relieved. Arthodesis is an example of joint resection. For this thesis we will focus on cartilage restoration. 
Restoration implies methods to heal or regenerate the joint surface with or without the subchondral bone into healthy hyaline articular cartilage. Three strategies can be considered when attempts are made to heal or restore cartilage.

Pharmacological agents that systemically treat generalized osteoarthritis are a "holy grail". Many investigators have hoped to find a systemic treatment, but such a reagent has not been identified yet. Intra-articular agents can be divided in four categories; (i) corticosteroids, (ii) hyaluronan, iii) growth factors, and (iv) enzymes. Glucosamine/Chondroitine Sulfate supplements are used systemically. Different results have been found regarding corticosteroids. While Olah et al. report that corticosteroids enhance cartilage healing ${ }^{87}$, most authors describe impaired physiology of healthy cartilag ${ }^{88-92}$. Hyaluronan(HYA) is widely used, but its mechanism is not completely understood. Its effect is probably more than just lubrication. HYA possibly has a direct biomechanical effect and has been reported to prevent chondrocytes from apoptosis via binding to their CD44 receptors ${ }^{22,23,93}$. A process in which the size of the HYA molecules was shown to play an important role ${ }^{94}$. Transforming Growth Factor $\beta_{1}\left(\right.$ TGF- $\left.\beta_{1}\right)$ and members of its superfamily such as Bone Morphogenic Protein (BMP) 2, 4 and 7 have chondrogenic effects when used in vitro. Intra-articular injection of TGF$\beta$ resulted in the formation of osteophytes in multiple studies ${ }^{95-98}$. Cartilage lacks blood vessels and the architecture of the ECM may prevent chondrocytes from migrating and adhering to damaged $\operatorname{sites}^{1,99}$. Bos et al. found that enzymatic digestion of cartilage defects results in an increase of cellularity near the wound edges ${ }^{72}$. Integration of cartilage discs into surrounding cartilage was also shown to be improved using an enzymatic digestion ${ }^{72,100}$. Others have reported that the use of proteolytic enzymes such as trypsin and chondroitinase enhances cartilage repair in animal models ${ }^{1,99,101}$. Oral therapies using Chondroitin and Glucosamine have described to relieve pain and increase joint mobility in $\mathrm{OA}^{102}$. In vitro, stimulation of GAG production, inhibition of ECM degredation, and anti inflammatory effects have been postulated to be the mechanism of action of Glucosamine and Chondrotin supplementation ${ }^{103}$. However serum levels after ingestion are much lower than those used for in vitro experiments ${ }^{104}$. Overall the usefulness of the supplements for the treatment of cartilage defects remains unknown.

Subchondral Drilling, Abrasion of Microfracture are techniques that allow penetration of bone marrow through the subchondral bone into the damaged cartilage ${ }^{69,71,105-112}$. These techniques improve the clinical well being of the patient and the joint surface defect may be healed to some extend. However the healing process is inadequate since no functional hyaline cartilage but fibrocartilage is formed ${ }^{106,112}$. However, these methods are cheap and easy to perform and are therefore seen as the best option to do no harm and relieve the 
complaints. Other clinical studies have suggested that any beneficial effect is related to the arthroscopic procedure itself. A nonspecific effect might be related to joint lavage rather than the penetration of the subchondral bone ${ }^{113,114}$. In conclusion, these techniques may have some benefit with regard to small defects and no effect has been proved in relation to large defects, osteoarthritic joints or older patients ${ }^{71}$.

Implants vary from non-absorbable and absorbable implants, cells, periosteum or perichondium, Osteochondral Autograft Transfer System (OATS or Mosaicplasty) and Osteochondral Allografts ${ }^{95,15-120}$. The biomaterials, and periosteum can be combined with cells or growth factors.

Periosteal Arthroplasty is an interesting way of treating cartilage defects since many have reported the chondrogenic potential of periosteum ${ }^{55,62,79,83,85,121-128}$. More than 90 percent of collagen type II has been reported in the hyaline cartilage formed in the cartilage defects treated with periosteal grafts 79,85 . The cambium layer should be place so that it faces towards the joint surface (fibrin layer towards the subchondral bone). Anchoring the graft with sutures through the subchondral bone ensures a good fixation. This way the graft can be placed deep into the defect avoiding shear forces. If these measures are taken, and the meticulous procedures of harvesting and handling the grafts are followed (ensuring the presence of a vital cambium layer), the use of this technique seems quite promising.

Perichondrial Arthroplasty used for human cartilage repair was first described by Skoog et al. ${ }^{129}$. This technique has been reported to give an initial cartilage repair ${ }^{130,131}$. On the long term poor results related to overgrowth of the graft and calcification as reported by Bouwmeester et al. ${ }^{132}$. These authors concluded that a better fixation of the graft might improve the results. In a study comparing periosteum with perichondrium, chondrogenesis was observed significantly frequently using periosteal grafts ${ }^{133}$. This finding and the accessibility make periosteum to be preferred over perichondrium.

Osteochondral Grafts can be divided in autogenous and allogeneous. Mosaicplasty or OATS involves harvesting one or more osteochondral plugs from a relatively less weight-bearing region of the joint and subsequent implantation of this graft into an articular defect. Repair of cartilage defects in the knee and talar dome seem to be successful however donor site complications remain a concern. This possible donor site morbidity is bypassed if osteochondral allografts are used ${ }^{134-142}$. Although not exclusively proven, this technique is reported to be successful when applied for articular defects of the knee ${ }^{136,139}$. Although chondrocyte viability was demonstrated in grafts which were refrigerated for twenty-four to forty-eight hours ${ }^{143}$, the viability decreases within 3 weeks after 
transplantation. The immune response to fresh allografts is more intense compared to frozen allografts ${ }^{144}$.

Biomaterials such as carbon fiber, dacron, teflon, (co)polymers, fibrin, hyaluronan and collagen have been investigated. Non-absorbable materials have not proved successful in restoring cartilage. Absorbable polymers, hyaluronan and collagens hold promise, especially when used as scaffold (see below) and combined with cells or growth factors ${ }^{145,146}$ and are currently tested clinically.

Tissue Engineering (TE) is the latest technique in which implants are created by combining principles from biology, engineering and medicine. The ideal graft should replicate the site-specific properties of the damaged tissue across different scales and provide the continuity and strength of the interface with neighboring host tissues, The most important elements of TE are:

Scaffolds are used as cell carriers to keep transplanted cells in the defect ${ }^{147,148}$. Several materials have been used for this purpose (e.g. fibrin, collagen, hyaluronan, ceramics, and (co)polymers). Generally scaffold materials can be divided in natural or synthetic. Examples of natural scaffolds are: fibrin, hyaluronan, alginate, agarose, demineralized bone matrix, collagen etc. Synthetic scaffolds include: ceramics and copolymers PolyGlycolic Lactic acid (PGLA) and PolyethyleneGlycol-terephthalate/PolyButylene Terephthalate (PEGT/PBT) (Figure 5) etc. Within time the ideal scaffold should degrade as the cells seeded on it deposit their own matrix and gain the specific features for the tissue to be repaired or replaced. Waste products and biomechanical features of the scaffold should not negatively influence with differentiation towards this tissue. It is therefore challenging to design as scaffold with the proper biomechanical and degradation characteristics. Next generation scaffolds are so called "smart scaffolds", these scaffolds are loaded with bioactive factors (e.g. TGF- $\beta_{1}$ and members of its superfamily such as BMP's) that can directly influence the differentiation pathway ${ }^{145,146,149}$. An ideal material has not been identified yet. When applying a collagen as carrier material, some find an enhanced cartilage healing, others conclude that collagen scaffolds have a limited usefulness for chondrocyte grafting in large defects ${ }^{119,147,150,151}$. The use of fibrin as carrier material was reported to give superior cartilage healing compared to controls (empty defect $)^{118}$.

Cells for "orthopaedic" tissues such as bone, cartilage and ligaments originate from the mesenchymal cell line. Cells can be released from their matrix, selected and expanded in vitro. This way a relatively small amount of tissue can be used as appropriate cell source. Both chondrocytes and progenitor cells originating from different cell sources have been studied in combination with these biomaterials $^{116,121,123,124,148,152-157}$. Bone marrow, periosteum, fat tissue, 
Gencral Introduction

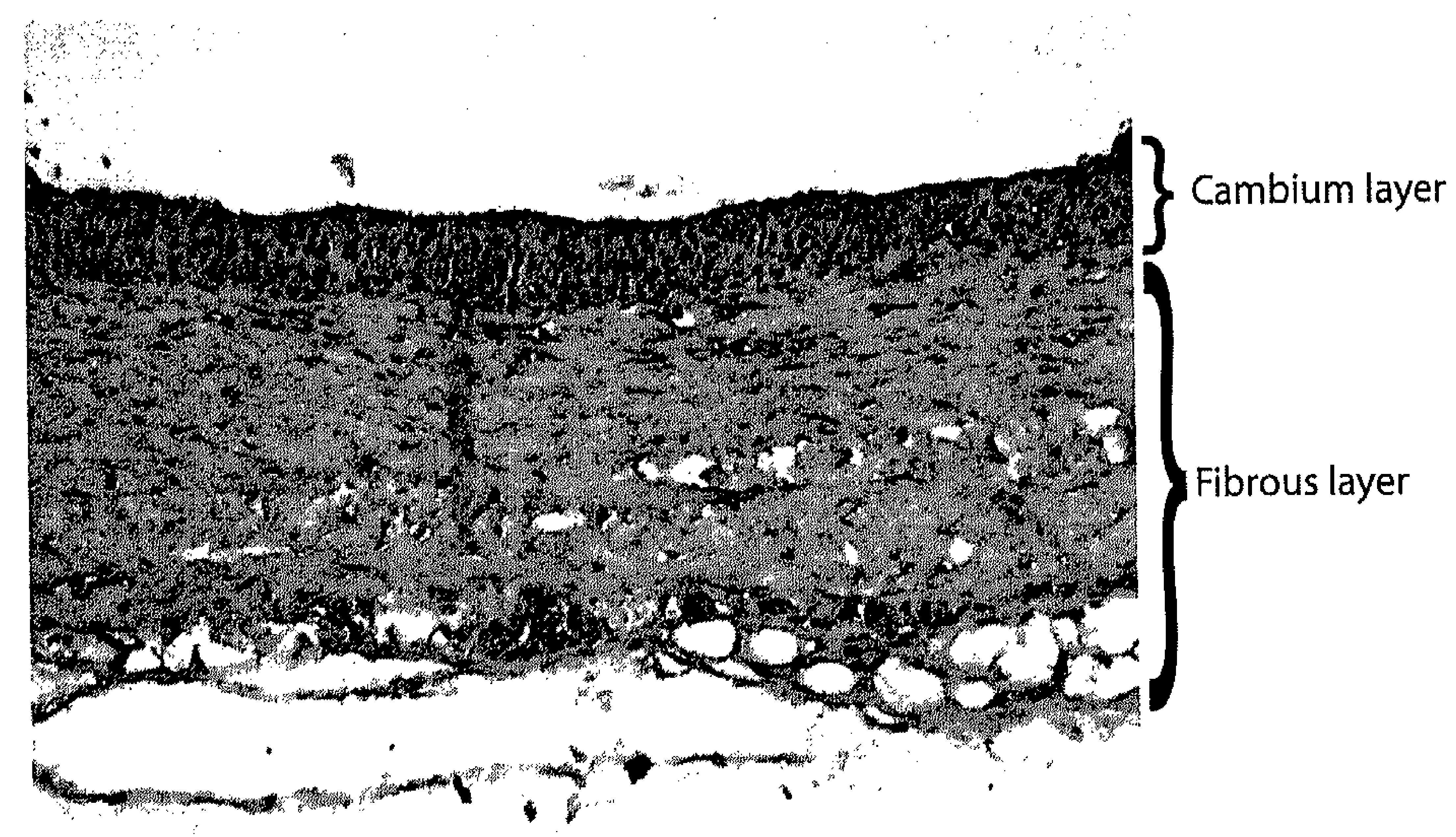

Figure 4: Periosteum, the cambium layer with it's osteochondral progenitor cells is attached to the bone.

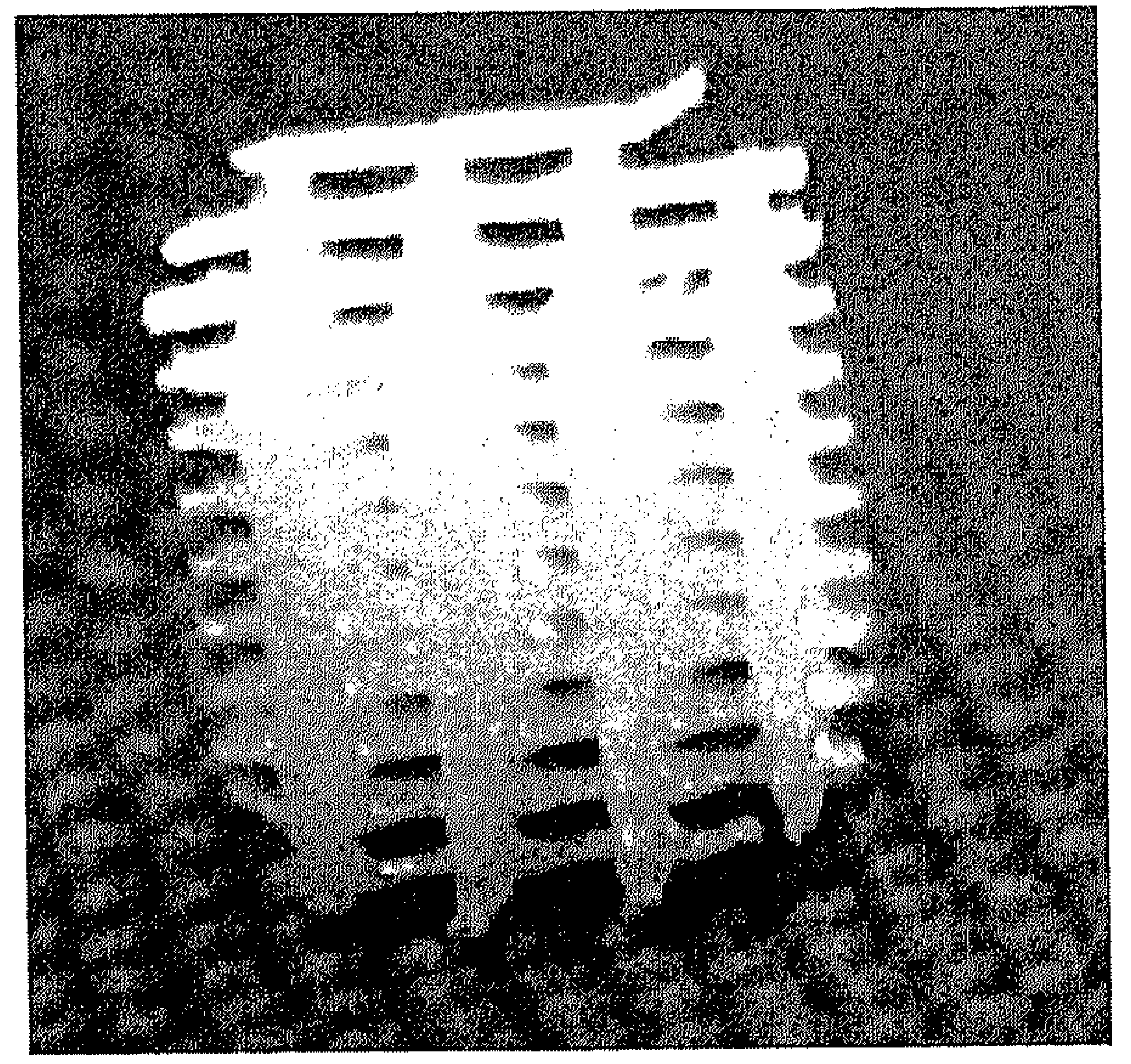

Figure 5: A PolyethyleneGlycol-terephthalate /PolyButylene Terephthalate (PEGT/ PBT) scaffold produced by using a rapid prototyping technique.

synovium, dental mould and perichondium can serve as a source for pluripotent cells $^{1,52,55,61,62,85,129,131,132,153,157-160}$. If perichondrial cells are truly pluripotent remains unclear ${ }^{115}$. Some authors prefer the use of chondrocytes for transplantation while others prefer the use of undifferentiated pluripotent cells $1,46,52,55,61$, 
Chapter 1

22

$62,85,129,131,132,152,153,157-161$. The involvement of the subchondral bone may play

a role in cell source selection.

Chondrocytes are capable of producing cartilage under the appropriate conditions, but in a situation where bone formation is required (involvement of the subchondral bone) pluripotent cells might be a better cell source. After selection and expansion, the main challenge is to keep these cells in the damaged area of the joint and this challenge becomes even greater in larger defects ${ }^{148}$. Grande et al. reported that only 8 percent of the total number of cells in the healing tissue originated from transplanted chondrocytes ${ }^{162}$. Chondrocytes can be maintained in the defect by suturing a periosteal flap or a collagen mesh over the defect ${ }^{152,162,163}$. In general, humans defects appeared to have healed and histological evidence of repair with hyaline cartilage was seen in thirteen biopsy specimens ${ }^{152}$. However disparity between clinical results raises questions regarding the contribution of the transplanted cells.

Chondrocytes can also be seeded in a matrix, consequently this matrix can be implanted in a cartilage defect. This Matrix Assisted Chondrocyte Transplantation (MACT) is technically less demanding and has shown identical results compared to Autologous Chondrocyte Transplantation on the short term ${ }^{163}$ The use of allogenic chondrocytes has been reported to be successful in rabbits but this was not confirmed in horses ${ }^{147,150,151,155}$. Immunological rejection of allogenic chondrocytes upon implantation in rabbits has been reported and this remains a major concern when applying allogenic cells.

A bioreactor provides the optimal environment for growing cells before implanting the graft. In the bioreactor cells are generally expanded in monolayer and consequently seeded on the scaffold for differentation. For both expansion and differentiation a culture medium should provide nutrients and the desired growthfactors. The bioreactor can also provide the physical environment for cells to help them differentiate along the desired lineage and possibly improve their survival after transplantation. Examples are temperature, oxygen tension, pressure stimuli and flow of medium ${ }^{164,165}$.

Finally an interesting variation to the theme of implants is a report by Takahashi et al. who used the early fracture callus, induced at the iliac crest ${ }^{166}$. The early fracture callus was implanted into osteochondral defects of rabbit knees with excellent results. Recently Stevens et al. published an interesting paper of inducing chondrogenesis by subperiosteal injection of a hyaluronan based gel containing the antiangiogenic factor Suramin. The resulting tissue also resembled cartilage of early fracture callus ${ }^{167}$. The main advantage of this approach is that the body is used as its own "in-situ incubator"; cells provide their own 
matrix and complex and costly isolation, selection and culturing procedures are bypassed.

REFERENCES: SEE CHAPTER 2 


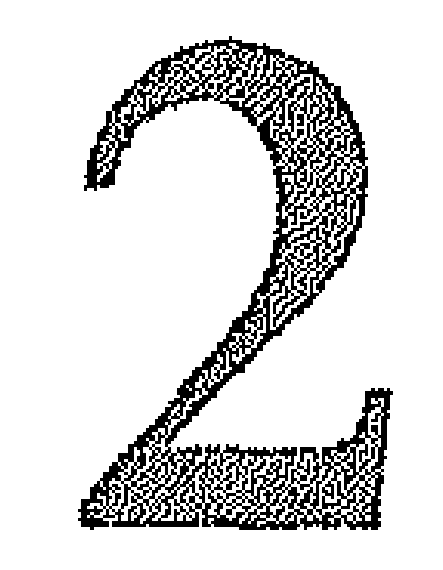

Aims of this thesis 
As stated in the General Introduction (Chapter 1), periosteum has chondrogenic potential. Especially cells of the periosteal cambium layer are known to be chondrogenic progenitor cells $79,85,126,127$. The thickness and total cell number in the cambium layer of the periosteum decreases with age ${ }^{55}$. In contrast to animal studies, periosteal arthroplasty was shown not to be successful in humans ${ }^{86,168}$. Although aged human periosteum has chondrogenic potential, graft fixation, thickness and the technique of harvesting periosteum may influence results of this technique ${ }^{55,169,170 .}$

In the latest cartilage repair techniques such as ACT and MACT, cells are harvested from articular cartilage ${ }^{152,163,171}$. This may affect joint homeostasis and implies expensive culture techniques. Thus alternative cell sources which do not interfere with the joint(homeostasis) and finding methods which bypass expensive and time consuming culture techniques are in order. A substantial part of this thesis is focused on isolating, culturing and survival of periosteal cell for cartilage repair. While these experiments use an in vitro expansion step, exploring in situ chondrogenesis of periosteum uses the body as its own in situ incubator. In general the aims of this thesis can be divided in experiments with isolated periosteal cells and experiments studying periosteal osteochondrogenesis in vivo.

Aims of this thesis if an in vitro expansion step is implemented, were; assessing the chondrogenic potential of aged human periosteum and optimizing proliferation and differentiation to see if these cells could be used as a cell source in techniques for cartilage repair (e.g. ACT or MACT). Furthermore we questioned if and what percentage of the isolated and expanded periosteal cells survived the implantation into a osteochondral defect. Culture and implantation conditions varied.

Aims of this thesis if the body is used as in situ incubator were; first of all to see if resection of a small piece of periosteum would lead to cartilage formation as can be observed during fracture callus formation. Simultaneously we assessed when in time cartilage formation takes place. Consequently the quality and amount of ectopically formed tissue was studied. We investigated onset and expression of essential growth factors and transcription factors during this process. Finally, cartilage repair using implantation of ectopically periosteum derived cartilage was examined in a conceptual study. 
Aims of this thesis

\section{REFERENCES}

1. Hunziker EB, Rosenberg LC. Repair of partial-thickness defects in articular cartilage: cell recruitment from the synovial membrane. J Bone Joint Surg Am 1996; 78(5): 721-33.

2. Mankin H, Mow V, Buckwalter J, Articular cartilage repair and osteoarthritis. Biology and Biomechanics of the Musculoskeletal System, ed. J. Buckwalter, T. Einhorn, and S. Simon. 2000, Rosemont: American Academy of Orthopaedic Surgeons.

3. Gelber AC, Hochberg MC, Mead LA, Wang NY, Wigley FM, Klag MJ.Joint injury in young adults and risk for subsequent knee and hip osteoarthritis. Ann Intern Med 2000; 133(5): $321-8$.

4. Sangha O. Epidemiology of rheumatic diseases. Rheumatology (Oxford) 2000;39 Suppl 2:312.

5. Hardaker WT, Jr., Garrett WE, Jr., Bassett FH, 3rd. Evaluation of acute traumatic hemarthrosis of the knee joint. South Med J 1990; 83(6):640-4.

6. Noyes FR, Bassett RW, Grood ES, Butler DL. Arthroscopy in acute traumatic hemarthrosis of the knee. Incidence of anterior cruciate tears and other injuries.J Bone Joint Surg Am 1980; 62(5): 687-95, 757.

7. Hjelle K, Solheim E, Strand T, Muri R, Brittberg M. Articular cartilage defects in 1,000 knee arthroscopies. Arthroscopy 2002; 18(7): 730-4.

8. Aroen A, Loken S, Heir S, Alvik E, Ekeland A, Granlund OG, et al. Articular cartilage lesions in 993 consecutive knee arthroscopies. Am J Sports Med 2004; 32(1):211-5.

9. Curl WW, Krome J, Gordon ES, Rushing J, Smith BP, Poehling GG. Cartilage injuries: a review of 31,516 knee arthroscopies. Arthroscopy 1997; 13(4): 456-60.

10. Urist $M$, Biogenesis of bone: Calcium and phophorus in the skeleton and blood in vertebrate evolution. Handbook of physiology, ed. R. Greep and E. Astwood. 1976, Washington DC: Am. Phys. Soc. 183-213.

11. Aydelotte $M$, Kuettner $\mathrm{K}$, Heterogeneity of articular chondrocytes and cartilage matrix. Cartilage degradation: Basic and clinical aspects, ed. J. Woessner and D.H. eds. 1992, New York: Marcel Dekker. 37-65.

12. Anderson H. Histochemical studies of the human hip joint. Acta Anat 1962; 48:258-292.

13. Gray DJ, Gardner E. Prenatal development of the human knee and superior tibiofibular joints. Am J Anat 1950; 86(2): 235-87.

14. Kuettner K, Pauli B, Vascularity of cartilage. Cartilage structure, function and biochemistry, ed. e. Hall BK. 1983, New York: Academic Press. 281 - 312.

15. McKibbin B, Maroudas A. Adult articular cartilage. Piman Medical 1979; 2E: 461 - 486.

16. Schenk R, Eggli P, Hunziker E, Articular cartilage morphology. Articular cartilage biochemistry, ed. K. Kuettner, R. Schleyerbach, and V. Hascall. 1986, New York: Raven Press. 3-22.

17. Poole AR, Kojima T, Yasuda T, Mwale F, Kobayashi M, Laverty S. Composition and structure of articular cartilage: a template for tissue repair. Clin Orthop Relat Res 2001(391 Suppl): S26-33.

18. Buckwalter J, Mankin H. Articular cartilage: tissue design and chondrocyte matrix interactions. AAOS Instr Cours Lect 1998; 47: 487-504.

19. Hasler EM, Herzog W, Wu JZ, Muller W, Wyss U. Articular cartilage biomechanics: theoretical models, material properties, and biosynthetic response. Crit Rev Biomed Eng 1999; 27(6): 415-88.

20. Aydelotte MB, Greenhill RR, Kuettner KE. Differences between sub-populations of cultured bovine articular chondrocytes. II. Proteoglycan metabolism. Connect Tissue Res $1988 ; 18(3): 223-34$. 
21. Noonan KJ, Stevens JW, Tammi R, Tammi M, Hernandez JA, Midura RJ. Spatial distribution of CD44 and hyaluronan in the proximal tibia of the growing rat.J Orthop Res 1996;14(4): $573-81$.

22. Lisignoli G, Grassi F, Zini N, Toneguzzi S, Piacentini A, Guidolin D, et al. Anti-Fas-induced apoptosis in chondrocytes reduced by hyaluronan: evidence for CD44 and CD54 (intercellular adhesion molecule 1) invovement. Arthritis Rheum 2001; 44(8): 1800-7.

23. Fujita Y, Kitagawa M, Nakamura S, Azuma K, Ishii G, Higashi M, et al. CD44 signaling through focal adhesion kinase and its anti-apoptotic effect. FEBS Lett 2002;528(1-3):101-8.

24. Mankin $\mathrm{H}$, Mow V, Buckwalter J, Articular cartilage structure, composition, and function. Orthopaedic basic science, ed. J. Buckwalter, T. Einhorn, and S. Simon. 2000, Rosemont: AAOS. 443-470.

25. Hunziker E, Articular cartilage structure in humans and experimental animals. Articular cartilage and osteoarthritis, ed. K. Kuettner, et al. 1992, New York: Raven Press. 183-199.

26. Radin EL, Martin RB, Burr DB, Caterson B, Boyd RD, Goodwin C. Effects of mechanical loading on the tissues of the rabbit knee.J Orthop Res 1984;2(3):221-34.

27. Donohue JM, Buss D, Oegema TR, Jr., Thompson RC, Jr. The effects of indirect blunt trauma on adult canine articular cartilage. J Bone Joint Surg Am 1983; 65(7): 948-57.

28. Ryan MC, Sandell LJ. Differential expression of a cysteine-rich domain in the aminoterminal propeptide of type II (cartilage) procollagen by alternative splicing of mRNA.J Biol Chem 1990;265(18): 10334-9.

29. Shinmei $M$, Inamori $Y$, Yoshihara $Y$, Kikuchi $T$, Hayakawa $T$, The potential of cartilage markers in joint fluid for drug evaluation. Articular cartilage and osteoarthritis, ed. K. Kuettner, et al. 1992, New York: Raven Press. 597-609.

30. Chang J, Nakajima H, Poole CA. Structural colocalisation of type VI collagen and fibronectin in agarose cultured chondrocytes and isolated chondrons extracted from adult canine tibial cartilage. J Anat 1997; 190 (Pt 4): 523-32.

31. Hambach L, Neureiter D, Zeiler G, Kirchner T, Aigner T. Severe disturbance of the distribution and expression of type VI collagen chains in osteoarthritic articular cartilage. Arthritis Rheum 1998; 41(6): 986-96.

32. Poole CA, Ayad S, Schofield JR. Chondrons from articular cartilage: I. Immunolocalization of type VI collagen in the pericellular capsule of isolated canine tibial chondrons.J Cell Sci 1988; 90 (Pt 4): 635-43.

33. Poole CA, Flint MH, Beaumont BW. Chondrons extracted from canine tibial cartilage: preliminary report on their isolation and structure. J Orthop Res 1988; 6(3): 408-19.

34. Poole CA, Ayad S, Gilbert RT. Chondrons from articular cartilage. V. Immunohistochemical evaluation of type VI collagen organisation in isolated chondrons by light, confocal and electron microscopy. J Cell Sci 1992; 103 (Pt 4): 1101-10.

35. Guilak F, Jones WR, Ting-Beall HP, Lee GM. The deformation behavior and mechanical properties of chondrocytes in articular cartilage. Osteoarthritis Cartilage 1999;7(1): 59-70.

36. Knight MM, Ross JM, Sherwin AF, Lee DA, Bader DL, Poole CA. Chondrocyte deformation within mechanically and enzymatically extracted chondrons compressed in agarose. Biochim Biophys Acta 2001; 1.526(2): 141-6.

37. Poole CA, Flint MH, Beaumont BW. Chondrons in cartilage: ultrastructural analysis of the pericellular microenvironment in adult human articular cartilages.J Orthop Res 1987;5(4): 509-22.

38. Eyre DR, Apon S, Wu JJ, Ericsson LH, Walsh KA. Collagen type IX: evidence for covalent linkages to type II collagen in cartilage. FEBS Lett 1987; 220(2):337-41.

39. van der Rest $M$, Mayne $R$. Type IX collagen proteoglycan from cartilage is covalently crosslinked to type Il collagen. J Biol Chem 1988;263(4):1615-8. 
40. Wu JJ, Eyre DR. Covalent interactions of type IX collagen in cartilage. Connect Tissue Res $1989 ; 20(1-4): 241-6$.

41. Muller-Glauser W, Humbel B, Glatt M, Strauli P, Winterhalter KH, Bruckner P. On the role of type IX collagen in the extracellular matrix of cartilage: type IX collagen is localized to intersections of collagen fibrils. J Cell Biol 1986; 102(5): 1931-9.

42. Eyre D, Wu J, Woods P, The cartilage-specific collagens: Structural studies. Articular cartilage and osteoarthritis, ed. K. Kuettner, et al. 1992, New York: Raven Press. 119-131.

43. Verzijl N, DeGroot J, Thorpe SR, Bank RA, Shaw JN, Lyons TJ, et al. Effect of collagen turnover on the accumulation of advanced glycation end products. J Biol Chem 2000;275(50): 39027-31.

44. Maroudas A, Uchitel N, Babyliss M, Gilav E. Racemization of aspartic acid in proteoglycans from human articular cartilage. Trans Orthop Res Soc 1994: 19:3.

45. Mok SS, Masuda K, Hauselmann HJ, Aydelotte MB, Thonar EJ. Aggrecan synthesized by mature bovine chondrocytes suspended in alginate. Identification of two distinct metabolic matrix pools. J Biol Chem 1994; 269(52):33021-7.

46. Hauselmann HJ, Fernandes RJ, Mok SS, Schmid TM, Block JA, Aydelotte MB, et al. Phenotypic stability of bovine articular chondrocytes after long-term culture in alginate beads. J Cell Sci 1994; 107 (Pt 1): 17-27.

47. Mark Kvd, Mollenhauer J, Pfaffle M, Menxel Mv, Mueller P, Role of anchorin C II in the interaction of chondrocytes with extracellular collagen. Articular cartilage biochemistry, ed. K.E. Kuettner, R. Schleyerbach, and V. Hascall. 1986, New York: Raven Press. 125-141.

48. Cs-Szabo G, Roughley PJ, Plaas AH, Glant TT. Large and small proteoglycans of osteoarthritic and rheumatoid articular cartilage. Arthritis Rheum 1995;38(5):660-8.

49. Buckwalter J, Mankin H. Articular Cartilage. J Bone Joint Surg Am 1997; 79-A: 600-632.

50. Simon S. Orthopaedic Basic Science. American Academy of Orthopaedic Surgeons 1994.

51. Duhamel H. Cited by Basset CAL in current concepts of bone formation.J Bone Joint Surg Am 1739; 44-A: 1217-1244.

52. Ito Y, Fitzsimmons JS, Sanyal A, Mello MA, Mukherjee N, O'Driscoll SW. Localization of chondrocyte precursors in periosteum. Osteoarthritis Cartilage 2001;9(3):215-23.

53. Kartsogiannis V, Moseley J, McKelvie B, Chou ST, Hards DK, Ng KW, et al. Temporal expression of PTHrP during endochondral bone formation in mouse and intramembranous bone formation in an in vivo rabbit model. Bone 1997; 21(5): 385-92.

54. Vortkamp A. Interaction of growth factors regulating chondrocyte differentiation in the developing embryo. Osteoarthritis Cartilage 2001; 9 Suppl A: S109-17.

55. O'Driscoll SW, Saris DB, Ito Y, Fitzimmons JS. The chondrogenic potential of periosteum decreases with age.J Orthop Res 2001;19(1): 95-103.

56. Horiuchi K, Amizuka N, Takeshita S, Takamatsu $\mathrm{H}$, Katsuura M, Ozawa H, et al. Identification and characterization of a novel protein, periostin, with restricted expression to periosteum and periodontal ligament and increased expression by transforming growth factor beta.J Bone Miner Res 1999; 14(7):1239-49.

57. Wilde J, Yokozeki M, Terai K, Kudo A, Moriyama $\mathrm{K}$. The divergent expression of periostin mRNA in the periodontal ligament during experimental tooth movement. Cell Tissue Res 2003; 312(3): 345-51.

58. Nakazawa T, Nakajima A, Seki N, Okawa A, Kato M, Moriya H, et al. Gene expression of periostin in the early stage of fracture healing detected by cDNA microarray analysis. J Orthop Res 2004; 22(3): 520-5.

59. Hall BK, Jacobson HN. The repair of fractured membrane bones in the newly hatched chick. Anat Rec 1975; 181(1): 55-69. 
60. Dowthwaite GP, Bishop JC, Redman SN, Khan IM, Rooney P, Evans DJ, et al. The surface of articular cartilage contains a progenitor cell population.J Cell Sci 2004; 117( $\mathrm{Pt} 6): 889-97$.

61. Park X, Sugimoto M, Watrin A, Chiquet M, Hunziker EB. BMP-2 induces the expression of chondrocyte-specific genes in bovine synovium-derived progenitor cells cultured in threedimensional alginate hydrogel. Osteoarthritis Cartilage 2005; 13(6): 527-36.

62. Emans PJ, Surtel DA, Frings EJ, Bulstra SK, Kuijer R. In vivo generation of cartilage from periosteum. Tissue Eng 2005; 11(3-4): 369-77.

63. Hunziker EB. Articular cartilage repair: are the intrinsic biological constraints undermining this process insuperable? Osteoarthritis Cartilage 1999; 7(1): 15-28.

64. Hunter W. Of the structure and disease of articulating cartilages. 1743. Clin Orthop Relat Res 1995(317):3-6.

65. Mankin HJ. The response of articular cartilage to mechanical injury. J Bone Joint Surg Am 1982; 64(3): 460-6.

66. Gold GE, Burstein D, Dardzinski B, Lang P, Boada F, Mosher T. MRI of articular cartilage in OA: novel pulse sequences and compositional/functional markers. Osteoarthritis Cartilage 2006; 14 Suppl 1:76-86.

67. Hunziker EB. Articular cartilage repair: basic science and clinical progress. A review of the current status and prospects. Osteoarthritis Cartilage 2002; 10(6): 432-63.

68. Bobic V, Noble J. Articular cartilage-to repair or not to repair. J Bone Joint Surg Br 2000; 82(2): 165-6.

69. Furukawa T, Eyre DR, Koide S, Glimcher MJ. Biochemical studies on repair cartilage resurfacing experimental defects in the rabbit knee. J Bone Joint Surg Am 1980; 62(1): 79-89.

70. Shapiro F, Koide S, Glimcher MJ. Cell origin and differentiation in the repair of full-thickness defects of articular cartilage. J Bone Joint Surg Am 1993; 75(4): 532-53.

71. Kim HK, Moran ME, Salter RB. The potential for regeneration of articular cartilage in defects created by chondral shaving and subchondral abrasion. An experimental investigation in rabbits. J Bone Joint Surg Am 1991; 73(9): 1301-15.

72. Bos PK, DeGroot J, Budde M, Verhaar JA, van Osch GJ. Specific enzymatic treatment of bovine and human articular cartilage: implications for integrative cartilage repair. Arthritis Rheum 2002; 46(4): 976-85.

73. Biswal S, Hastie T, Andriacchi TP, Bergman GA, Dillingham MF, Lang P. Risk factors for progressive cartilage loss in the knee: a longitudinal magnetic resonance imaging study in forty-three patients. Arthritis Rheum 2002; 46(11): 2884-92.

74. Bentley G. Articular cartilage studies and osteoarthrosis. Ann R Coll Surg Engl 1975; 57(2): 86-100.

75. Dhert WJ, O'Driscoll SW, van Royen BJ, Salter RB. Effects of immobilization and continuous passive motion on postoperative muscle atrophy in mature rabbits. Can J Surg 1988; $31(3): 185-8$

76. Kumar A, Wong DA, Johnson RG, Herbert MA, Salter RB. The restraint of rabbits in a special sling. Lab Anim Sci 1979; 29(4):512-5.

77. Moran ME, Kim HK, Salter RB. Biological resurfacing of full-thickness defects in patellar articular cartilage of the rabbit. Investigation of autogenous periosteal grafts subjected to continuous passive motion. J Bone Joint Surg Br 1992; 74(5): 659-67.

78. O'Driscoll SW, Kumar A, Salter RB. The effect of continuous passive motion on the clearance of a hemarthrosis from a synovial joint. An experimental investigation in the rabbit. Clin Orthop Relat Res 1983(176): 305-11.

79. O'Driscoll SW, Keeley FW, Salter RB. Durability of regenerated articular cartilage produced by free autogenous periosteal grafts in major full-thickness defects in joint surfaces under the 
Aims of this thesis

influence of continuous passive motion. A follow-up report at one year.J Bone Joint Surg Am 1988; 70(4): 595-606.

80. Salter RB. The biologic concept of continuous passive motion of synovial joints. The first 18 years of basic research and its clinical application. Clin Orthop Relat Res 1989(242):12-25.

81. van Royen BJ, O'Driscoll SW, Dhert WJ, Salter RB. A comparison of the effects of immobilization and continuous passive motion on surgical wound healing in mature rabbits. Plast Reconstr Surg 1986; 78(3):360-8.

82. Zarnett R, Delaney JP, Driscoll SW, Salter RB. Cellular origin and evolution of neochondrogenesis in major full-thickness defects of a joint surface treated by free autogenous periosteal grafts and subjected to continuous passive motion in rabbits. Clin Orthop Relat Res 1987(222): 267-74.

83. Zarnett R, Salter RB. Periosteal neochondrogenesis for biologically resurfacing joints: its cellular origin. Can J Surg 1989;32(3): 171-4.

84. Salter RB, Simmonds DF, Malcolm BW, Rumble EJ, MacMichael D, Clements ND. The biological effect of continuous passive motion on the healing of full-thickness defects in articular cartilage. An experimental investigation in the rabbit. J Bone Joint Surg Am 1980; 62(8): 1232-51.

85. O'Driscoll SW, Keeley FW, Salter RB. The chondrogenic potential of free autogenous periosteal grafts for biological resurfacing of major full-thickness defects in joint surfaces under the influence of continuous passive motion. An experimental investigation in the rabbit. J Bone Joint Surg Am 1986; 68(7): 1017-35.

86. O'Driscoll SW. The healing and regeneration of articular cartilage. J Bone Joint Surg Am 1998; 80(12): 1795-812.

87. Olah EH, Kostenszky KS. Effect of prednisolone on the glycosaminoglycan components of the regenerating articular cartilage. Acta Biol Acad Sci Hung 1976;27(2-3): 129-34.

88. Behrens F, Shepard N, Mitchell N. Metabolic recovery of articular cartilage after intra-articular injections of glucocorticoid. J Bone Joint Surg Am 1976; 58(8): 1157-60.

89. Mankin HJ, Conger KA. The acute effects of intra-articular hydrocortisone on articular cartilage in rabbits. J Bone Joint Surg Am 1966; 48(7): 1383-8.

90. Salter RB, Gross A, Hall JH. Hydrocortisone arthropathy-an experimental investigation. Can Med Assoc J 1967; 97(8): 374-7.

91. Shoemaker RS, Bertone AL, Martin GS, McIlwraith CW, Roberts ED, Pechman R, et al, Effects of intra-articular administration of methylprednisolone acetate on normal articular cartilage and on healing of experimentally induced osteochondral defects in horses. Am J Vet Res 1992; 53(8): 1446-53.

92. Silberberg $M$, Silberberg $R$, Hasler $M$. Fine structure of articular cartilage in mice receiving cortisone acetate. Arch Pathol 1966;82(6):569-82.

93. Iwata $\mathrm{H}$. Pharmacologic and clinical aspects of intraarticular injection of hyaluronate. Clin Orthop Relat Res 1993(289): 285-91.

94. Maneiro E, de Andres MC, Fernandez-Sueiro JL, Galdo F, Blanco FJ. The biological action of hyaluronan on human osteoartritic articular chondrocytes: the importance of molecular weight. Clin Exp Rheumatol 2004; 22(3): 307-12.

95. Elford PR, Graeber M, Ohtsu H, Aeberhard M, Legendre B, Wishart WL, et al. Induction of swelling, synovial hyperplasia and cartilage proteoglycan loss upon intra-articular injection of transforming growth factor beta-2 in the rabbit. Cytokine 1992; 4(3):232-8.

96. van Beuningen HM, van der Kraan PM, Arntz OJ, van den Berg WB. Does TGF-beta protect articular cartilage in vivo? Agents Actions Suppl 1993; 39:127-31. 
97. van Beuningen HM, van der Kraan PM, Arntz OJ, van den Berg WB. Transforming growth factor-beta 1 stimulates articular chondrocyte proteoglycan synthesis and induces osteophyte formation in the murine knee joint. Lab Invest 1994; 71(2): 279-90.

98. Hunziker EB. Growth-factor-induced healing of partial-thickness defects in adult articular cartilage. Osteoarthritis Cartilage 2001;9(1):22-32.

99. Hunziker EB, Kapfinger E. Removal of proteoglycans from the surface of defects in articular cartilage transiently enhances coverage by repair cells. J Bone Joint Surg Br 1998; 80(1): 14450.

100. van de Breevaart Bravenboer J, In der Maur CD, Bos PK, Feenstra L, Verhaar JA, Weinans H, et al. Improved cartilage integration and interfacial strength after enzymatic treatment in a cartilage transplantation model. Arthritis Res Ther 2004; 6(5): R469-76.

101. Lack W, Bosch P, Lintner F. Influence of trypsin on the regeneration of hyaline articular cartilage. Acta Orthop Scand 1986; 57(2): 123-5.

102. Towheed TE, Maxwell L, Anastassiades TP, Shea B, Houpt J, Robinson V, et al. Glucosamine therapy for treating osteoarthritis. Cochrane Database Syst Rev 2005(2): CD002946.

103. Bassleer C, Rovati L, Franchimont P. Stimulation of proteoglycan production by glucosamine sulfate in chondrocytes isolated from human osteoarthritic articular cartilage in vitro Osteoarthritis Cartilage 1998; 6(6): 427-34.

104. Biggee BA, Blinn CM, McAlindon TE, Nuite M, Silbert JE. Low levels of human serum glucosamine after ingestion of glucosamine sulphate relative to capability for peripheral effectiveness. Ann Rheum Dis 2006; 65(2): 222-6.

105. Aglietti P, Buzzi R, Bassi PB, Fioriti M. Arthroscopic drilling in juvenile osteochondritis dissecans of the medial femoral condyle. Arthroscopy 1994; 10(3): 286-91.

106. Altman RD, Kates J, Chun LE, Dean DD, Eyre D. Preliminary observations of chondral abrasion in a canine model. Ann Rheum Dis 1992; 51(9): 1056-62.

107. Bradley J, Dandy DJ. Results of drilling osteochondritis dissecans before skeletal maturity. J Bone Joint Surg Br 1989; 71(4): 642-4.

108. Insall J. The Pridie debridement operation for osteoarthritis of the knee. Clin Orthop Relat Res 1974(101):61-7.

109. Meachim G, Roberts C. Repair of the joint surface from subarticular tissue in the rabbit knee. J Anat 1971; 109(2): 317-27.

110. Mitchell N, Shepard N. The resurfacing of adult rabbit articular cartilage by multiple perforations through the subchondral bone. J Bone Joint Surg Am 1976; 58(2):230-3.

111. Rae PJ, Noble J. Arthroscopic drilling of osteochondral lesions of the knee.J Bone Joint Surg Br 1989; 71(3): 534.

112. Vachon A, Bramlage LR, Gabel AA, Weisbrode S. Evaluation of the repair process of cartilage defects of the equine third carpal bone with and without subchondral bone perforation. Am J Vet Res 1986; 47(12):2637-45.

113. Jackson RW. The scope of arthroscopy. Clin Orthop Relat Res 1986(208): 69-71.

114. Ogilvie-Harris DJ, Fitsialos DP. Arthroscopic management of the degenerative knee. Arthroscopy 1991; 7(2): 151-7.

115. Chu CR, Coutts RD, Yoshioka M, Harwood FL, Monosov AZ, Amiel D. Articular cartilage repair using allogeneic perichondrocyte-seeded biodegradable porous polylactic acid (PLA): a tissue-engineering study.J Biomed Mater Res 1995; 29(9): 1147-54.

116. Freed LE, Vunjak-Novakovic G, Langer R. Cultivation of cell-polymer cartilage implants in bioreactors. J Cell Biochem 1993; 51(3): 257-64.

117. Grande DA, Halberstadt C, Naughton G, Schwartz R, Manji R. Evaluation of matrix scaffolds for tissue engineering of articular cartilage grafts. J Biomed Mater Res 1997;34(2):211-
20 . 
118. Hendrickson DA, Nixon AJ, Grande DA, Todhunter RJ, Minor RM, Erb H, et al. Chondrocyte-fibrin matrix transplants for resurfacing extensive articular cartilage defects.J Orthop Res 1994; 12(4): 485-97.

119. Nixon AJ, Sams AE, Lust G, Grande D, Mohammed HO. Temporal matrix synthesis and histologic features of a chondrocyte-laden porous collagen cartilage analogue. Am J Vet Res 1993; 54(2): 349-56.

120. Reddi AH. Symbiosis of biotechnology and biomaterials: applications in tissue engineering of bone and cartilage. J Cell Biochem 1994; 56(2): 192-5.

121. Gallay SH, Miura Y, Commisso CN, Fitzsimmons JS, O'Driscoll SW. Relationship of donor site to chondrogenic potential of periosteum in vitro. J Orthop Res 1994; 12(4): 515-25.

122. Iwasaki M, Nakahara $H$, Nakase T, Kimura T, Takaoka K, Caplan AI, et al. Bone morphogenetic protein 2 stimulates osteogenesis but does not affect chondrogenesis in osteochondrogenic differentiation of periosteum-derived cells.J Bone Miner Res 1994; 9(8): 1195-204.

123. Iwasaki M, Nakahara H, Nakata K, Nakase T, Kimura T, Ono K. Regulation of proliferation and osteochondrogenic differentiation of periosteum-derived cells by transforming growth factor-beta and basic fibroblast growth factor. J Bone Joint Surg Am 1995; 77(4): 543-54.

124. Iwasaki M, Nakata K, Nakahara H, Nakase T, Kimura T, Kimata K, et al. Transforming growth factor-beta 1 stimulates chondrogenesis and inhibits osteogenesis in high density culture of periosteum-derived cells. Endocrinology 1993; 132(4): 1603-8.

125. Nakata K, Nakahara H, Kimura T, Kojima A, Iwasaki M, Caplan AI, et al. Collagen gene expression during chondrogenesis from chick periosteum-derived cells. FEBS Lett 1992; 299(3): 278-82.

126. Nakahara H, Bruder SP, Goldberg VM, Caplan AI. In vivo osteochondrogenic potential of cultured cells derived from the periosteum. Clin Orthop Relat Res 1990(259):223-32.

127. Nakahara H, Dennis JE, Bruder SP, Haynesworth SE, Lennon DP, Caplan AI. In vitro differentiation of bone and hypertrophic cartilage from periosteal-derived cells. Exp Cell Res 1991; 195(2): 492-503.

128. Nakahara H, Goldberg VM, Caplan AI. Culture-expanded human periosteal-derived cells exhibit osteochondral potential in vivo.J Orthop Res 1991;9(4): 465-76.

129. Skoog $\mathrm{T}$, Johansson SH. The formation of articular cartilage from free perichondrial grafts. Plast Reconstr Surg 1976; 57(1): 1-6.

130. Homminga GN, Bulstra SK, Bouwmeester PS, van der Linden AJ. Perichondral grafting for cartilage lesions of the knee. J Bone Joint Surg Br 1990; 72(6): 1003-7.

131. Homminga GN, Bulstra SK, Kuijer R, van der Linden AJ. Repair of sheep articular cartilage defects with a rabbit costal perichondrial graft. Acta Orthop Scand 1991; 62(5): 415-8.

132. Bouwmeester SJ, Beckers JM, Kuijer R, van der Linden AJ, Bulstra SK. Long-term results of rib perichondrial grafts for repair of cartilage defects in the human knee. Int Orthop 1997; 21(5):313-7.

133. Vachon A, McIlwraith CW, Trotter GW, Norrdin RW, Powers BE. Neochondrogenesis in free intra-articular, periosteal, and perichondrial autografts in horses. Am J Vet Res 1989; $50(10): 1787-94$.

134. Convery FR, Meyers $\mathrm{MH}$, Akeson WH. Fresh osteochondral allografting of the femoral condyle. Clin Orthop Relat Res 1991(273): 139-45.

135. Czitrom AA, Keating S, Gross AE. The viability of articular cartilage in fresh osteochondral allografts after clinical transplantation. J Bone Joint Surg Am 1990; 72(4):574-81.

136. Garrett JC. Treatment of osteochondral defects of the distal femur with fresh osteochondral allografts: a preliminary report. Arthroscopy $1986 ; 2(4): 222-6$. 
Chapter 2

34

137. Garrett JC. Fresh osteochondral allografts for treatment of articular defects in osteochondritis dissecans of the lateral femoral condyle in adults. Clin Orthop Relat Res 1994(303):33-7.

138. Garrett JC. Osteochondral allografts for reconstruction of articular defects of the knee. Instr Course Lect 1998; 47:517-22.

139. Ghazavi MT, Pritzker KP, Davis AM, Gross AE. Fresh osteochondral allografts for post-traumatic osteochondral defects of the knee.J Bone Joint Surg Br 1997; 79(6): 1008-13.

140. Gross AE, Aubin P, Cheah HK, Davis AM, Ghazavi MT. A fresh osteochondral allograft alternative.J Arthroplasty 2002; 17(4 Suppl 1):50-3.

141. Gross AE, McKee NH, Pritzker KP, Langer F Reconstruction of skeletal deficits at the knee. A comprehensive osteochondral transplant program. Clin Orthop Relat Res 1983(174):96106.

142. Horas U, Schnettler R, Pelinkovic D, Herr G, Aigner T. [Osteochondral transplantation versus autogenous chondrocyte transplantation. A prospective comparative clinical study]. Chirurg 2000; 71(9): 1090-7.

143. Sammarco VJ, Gorab R, Miller R, Brooks PJ. Human articular cartilage storage in cell culture medium: guidelines for storage of fresh osteochondral allografts. Orthopedics 1997; 20(6): 497-500.

144. Stevenson S, Dannucci GA, Sharkey NA, Pool RR. The fate of articular cartilage after transplantation of fresh and cryopreserved tissue-antigen-matched and mismatched osteochondral allografts in dogs. J Bone Joint Surg Am 1989; 71(9): 1297-307.

145. Sellers RS, Peluso D, Morris EA. The effect of recombinant human bone morphogenetic protein-2 (rhBMP-2) on the healing of full-thickness defects of articular cartilage. J Bone Joint Surg Am 1997; 79(10): 1452-63.

146. Sellers RS, Zhang R, Glasson SS, Kim HD, Peluso D, D'Augusta DA, et al. Repair of articular cartilage defects one year after treatment with recombinant human bone morphogenetic protein-2 (rhBMP-2). J Bone Joint Surg Am 2000; 82(2): 151-60.

147. Wakitani S, Kimura T, Hirooka A, Ochi T, Yoneda M, Yasui N, et al. Repair of rabbit articular surfaces with allograft chondrocytes embedded in collagen gel.J Bone Joint Surg Br 1989; 71(1): 74-80.

148. Bentley G, Greer RB, 3rd. Homotransplantation of isolated epiphyseal and articular cartilage chondrocytes into joint surfaces of rabbits. Nature 1971;230(5293):385-8.

149. Huang Q, Goh JC, Hutmacher DW, Lee EH. In vivo mesenchymal cell recruitment by a scaffold loaded with transforming growth factor beta 1 and the potential for in situ chondrogenesis. Tissue Eng 2002; 8(3); 469-82.

150. Sams AE, Nixon AJ. Chondrocyte-laden collagen scaffolds for resurfacing extensive articular cartilage defects. Osteoarthritis Cartilage 1995;3(1): 47-59.

151. Sams AE, Minor RR, Wootton JA, Mohammed H, Nixon AJ. Local and remote matrix responses to chondrocyte-laden collagen scaffold implantation in extensive articular cartilage defects. Osteoarthritis Cartilage 1995; 3(1): 61-70.

152. Brittberg M, Lindahl A, Nilsson A, Ohlsson C, Isaksson O, Peterson L. Treatment of deep cartilage defects in the knee with autologous chondrocyte transplantation. $N$ Engl J Med 1994; 331(14): 889-95.

153. Bruder SP, Fink DJ, Caplan AI. Mesenchymal stem cells in bone development, bone repair, and skeletal regeneration therapy.J Cell Biochem 1994;56(3):283-94.

154. Freed LE, Marquis JC, Nohria A, Emmanual J, Mikos AG, Langer R. Neocartilage formation in vitro and in vivo using cells cultured on synthetic biodegradable polymers. J Biomed Mater Res 1993; 27(1): 11-23. 
155. Freed LE, Grande DA, Lingbin Z, Emmanual J, Marquis JC, Langer R. Joint resurfacing using allograft chondrocytes and synthetic biodegradable polymer scaffolds. J Biomed Mater Res 1994; 28(8): 891-9.

156. Haynesworth SE, Baber MA, Caplan AI. Cell surface antigens on human marrow-derived mesenchymal cells are detected by monoclonal antibodies. Bone 1992; 13(1):69-80.

157. Wakitani S, Goto T, Pineda SJ, Young RG, Mansour JM, Caplan AI, et al. Mesenchymal cellbased repair of large, full-thickness defects of articular cartilage. J Bone Joint Surg Am 1994; 76(4): 579-92.

158. Nathan S, Das De S, Thambyah A, Fen C, Goh J, Lee EH. Cell-based therapy in the repair of osteochondral defects: a novel use for adipose tissue. Tissue Eng 2003; 9(4):733-44.

159. Chu CR, Dounchis JS, Yoshioka M, Sah RL, Coutts RD, Amiel D. Osteochondral repair using perichondrial cells. A 1-year study in rabbits. Clin Orthop Relat Res 1997(340):220-9.

160. Engkvist O, Johansson SH, Ohlsen L, Skoog T. Reconstruction of articular cartilage using autologous perichondrial grafts. A prelininary report. Scand J Plast Reconstr Surg 1975;9(3): 203-6.

161. Lindahl A, Brittberg M, Peterson L. Cartilage repair with chondrocytes: clinical and cellular aspects. Novartis Found Symp 2003; 249: 175-86; discussion 186-9, 234-8, 239-41.

162. Grande DA, Pitman MI, Peterson L, Menche D, Klein M. The repair of experimentally produced defects in rabbit articular cartilage by autologous chondrocyte transplantation. J Orthop Res 1989; 7(2): 208-18.

163. Bartlett W, Skinner JA, Gooding CR, Carrington RW, Flanagan AM, Briggs TW, et al. Autologous chondrocyte implantation versus matrix-induced autologous chondrocyte implantation for osteochondral defects of the knee: a prospective, randomised study. J Bone Joint Surg Br 2005; 87(5): 640-5.

164. Lee CR, Grodzinsky AJ, Spector M. Biosynthetic response of passaged chondrocytes in a type II collagen scaffold to mechanical compression. J Biomed Mater Res A 2003; 64(3): 560-9.

165. Malda J, van Blitterswijk CA, van Geffen M, Martens DE, Tramper J, Riesle J. Low oxygen tension stimulates the redifferentiation of dedifferentiated adult human nasal chondrocytcs. Osteoarthritis Cartilage 2004; 12(4):306-13.

166. Takahashi S, Oka M, Kotoura Y, Yamamuro T. Autogenous callo-osseous grafts for the repair of osteochondral defects. J Bone Joint Surg Br 1995; 77(2): 194-204.

167. Stevens MM, Marini RP, Schaefer D, Aronson J, Langer R, Shastri VP. In vivo engineering of organs: the bone bioreactor. Proc Natl Acad Sci U S A 2005; 102(32): 11450-5.

168. Lorentzon R, Alfredson H, Hildingsson C. Treatment of deep cartilage defects of the patella with periosteal transplantation. Knee Surg Sports Traumatol Arthrosc 1998; 6(4):202-8.

169. O'Driscoll SW, Fitzsimmons JS. The importance of procedure specific training in harvesting periosteum for chondrogenesis. Clin Orthop Relat Res 2000(380):269-78.

170. O'Driscoll SW. Technical considerations in periosteal grafting for osteochondral injuries. Clin Sports Med 2001;20(2):379-402, vii.

171. Brittberg M, Peterson L, Sjogren-Jansson E, Tallheden T, Lindahl A. Articular cartilage engineering with autologous chondrocyte transplantation. A review of recent developments. J Bone Joint Surg Am 2003; 85-A Suppl 3: 109-15. 


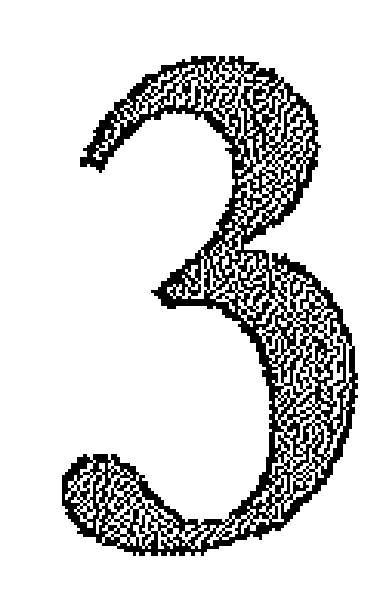

The effects of different decalcification protocols on TUNEL and general cartilage staining

Emans P.J., Bulstra S.K., Kuijer R.

Biotech Histochem. 2005 May-Aug;80(3):111-5. 


\begin{abstract}
Apoptosis is characterized by DNA strand breaks with a $3^{\prime}-\mathrm{OH}$ terminus, which are analyzed by terminal deoxy(d)-UTP nick end labeling (TUNEL). Proteinase $\mathrm{K}$ digestion is thought to be an essential step in the TUNEL procedure. The effects of decalcifying reagents on general staining and the TUNEL assay for cartilage sections are largely unknown. The effects of these reagents on retention and integrity of DNA in chondrocytes have not been described until now. We evaluated the effects of various decalcifying solutions including 10\% EDTA, $10 \%$ citric acid, $5 \%$ trichloric acid, $5 \%$ asetic acid and a commercial hydrochloric acid-based reagent on general cartilage staining and TUNEL assay for cartilage. The effects of proteinase $\mathrm{K}$ on nucleus preservation were also examined. Decalcification with 10\% EDTA gave the best result for general cartilage staining. Chondrocyte DNA was retained and intact using this reagent. Decalcification with 10\% EDTA is also the safest method of decalcification if the TUNEL assay is applied to cartilage. Proteinase $\mathrm{K}$ digestion had adverse effects on nucleus preservation in cartilage. Awareness of these effects is important whenever the TUNEL assay is applied.
\end{abstract}

\title{
INTRODUCTION
}

For good histological assessment of cartilage, bone and cartilage must be examined in one piece. Decalcification of these tissues is a time-consuming process mostly taking several weeks. Several reagents are used for decalcification. It is known that these reagents often have negative effects on morphological preservation, antigenicity, and the integrity of $\mathrm{DNA}^{1,2}$. Commercial hydrochloric acid $(\mathrm{HCl})$ - based, decalcification solutions especially are known to produce these negative effects ${ }^{1}$.

Terminal deoxy(d)-UTP nick end labeling (TUNEL), allows localization of double-strand DNA breaks caused by endonucleases during apoptosis ${ }^{3,4}$. Only a few studies have used this method for detection of apoptotic cells after decalcification ${ }^{5,6}$. Therefore, it is essential to determine the effects of decalcification reagents on general cartilage staining and DNA integrity of chondrocytes.

The aim of our study was to test the following decalcification reagents; (1) $10 \%$ EDTA (pH 7,5), (2) 10\% citric acid (pH 2,0), (3) 5\% trichloroacetic acid (TCA) ( $\mathrm{pH} 1,6),(4) 5 \%$ glacial acid ( $\mathrm{pH} 2,3)$, and (5) half the concentration of a commercial HCl- based decalcification solution (TBD-1, ThermoShandon, Pittsburg, PA). One percent formaldehyde was added to al these reagents. We 
determined the time required for decalcification, the quality of hematoxylin/eosin $(\mathrm{H} \& \mathrm{E})$ and thionine staining, and the retention and integrity of DNA using 4', 6-diaminodino-2-phenidole (DAPI) and TUNEL staining.

\section{METHODS AND MATERIALS}

\section{Preservation of tissues}

All work in this study was approved by the Maastricht University Committee for animal experiments. Fifteen adult female New Zealand White rabbits were killed with an overdose barbiturate. The femoral condyles were dissected and fixed overnight in $4 \%$ buffered formaldehyde solution. The average weight of the condyles was 1.71 grams (range $1.17-2.38$ ). The condyles were divided at random into five groups $(n=6)$ and decalcified in the five different reagents under investigation at room temperature. The composition of the decalcifying solutions are given in Table 1 . The time required for complete decalcification was determined by examining the tissues with soft $\mathrm{X}$-ray imaging at $1,2,3,4,5,6,7,8$ days and weekly hereafter.

After decalcification, each samples was divided in two halves and subsequently dehydrated in a series of ethanol solutions. One halve the condyle was embedded in paraffin wax; the other halve was embedded in glycol methacrylate (GMA; Technovit 7100, Heraeus Kulzer, Germany). Fivemicrometer-thick GMA sections were mounted on normal microscope slides. The five $\mu \mathrm{M}$ thick paraffin sections were mounted on Superfrost Plus slides (Menzel Glaser, Germany) and subsequently deparaffinized.

Table 1: Composition of the decalcifying solutions

\begin{tabular}{llll}
\hline Solution & Ingredients & Quantity & $\mathrm{pH}$ \\
\hline EDTA & Titriplex III & $10 \mathrm{~g} / 100 \mathrm{ml}(10 \%)$ & 7.5 \\
& NaOH pellets & $\begin{array}{l}\text { to adjust } \mathrm{pH} \text { to } 7,5 \\
\text { Paraformaldehyde }\end{array}$ & $0.4 \mathrm{~g} / 100 \mathrm{ml}$ \\
Citric acid & Citric acid & $10 \mathrm{~g} / 100 \mathrm{ml}(10 \%)$ & 2 \\
& Paraformaldehyde & $0.4 \mathrm{~g} / 100 \mathrm{ml}$ & \\
TCA & TCA & $5 \mathrm{~g} / 100 \mathrm{ml}(5 \%)$ & \multirow{2}{*}{1.6} \\
& Paraformaldehyde & $0.4 \mathrm{~g} / 100 \mathrm{ml}$ & \\
Acetic acid & Acetic Acid & $5 \mathrm{ml} / 100 \mathrm{ml}(5 \%)$ & 2.3 \\
& Paraformaldehyde & $0.4 \mathrm{~g} / 100 \mathrm{ml}$ & \\
TBD-1 (50\%) & TBD-1 & $50 \mathrm{ml} / 100 \mathrm{ml}(50 \%)$ & \\
& Paraformaldehyde & $0.4 \mathrm{~g} / 100 \mathrm{ml}$ & \\
\hline
\end{tabular}


$40 \mid$

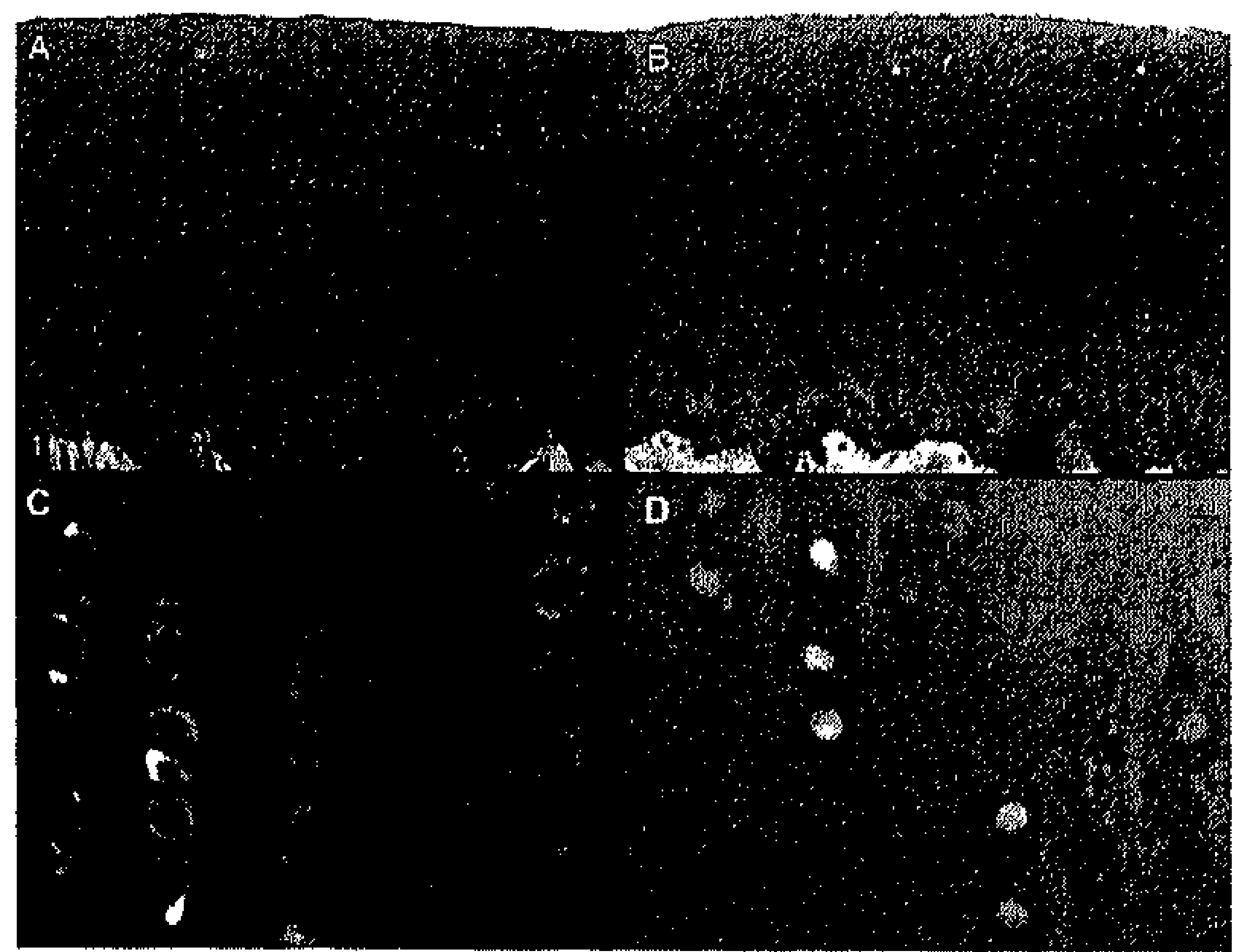

Figure 1: (A) Rabbit cartilage decalcified with 10\% EDTA and stained with thionine. Note the intense matrix staining and the presence of nuclei. (B) Rabbit articular cartilage after decalcification with of the diluted TBD-1 solution and thionin staining. Note the weaker matrix staining and the absence of nuclei.. (C and $D$ ) Enlargements of $(A)$ and $(B)$, respectively. $A$ and $B, X 50 ; C$ and $D, X 400$. See page 145 for colour figure.
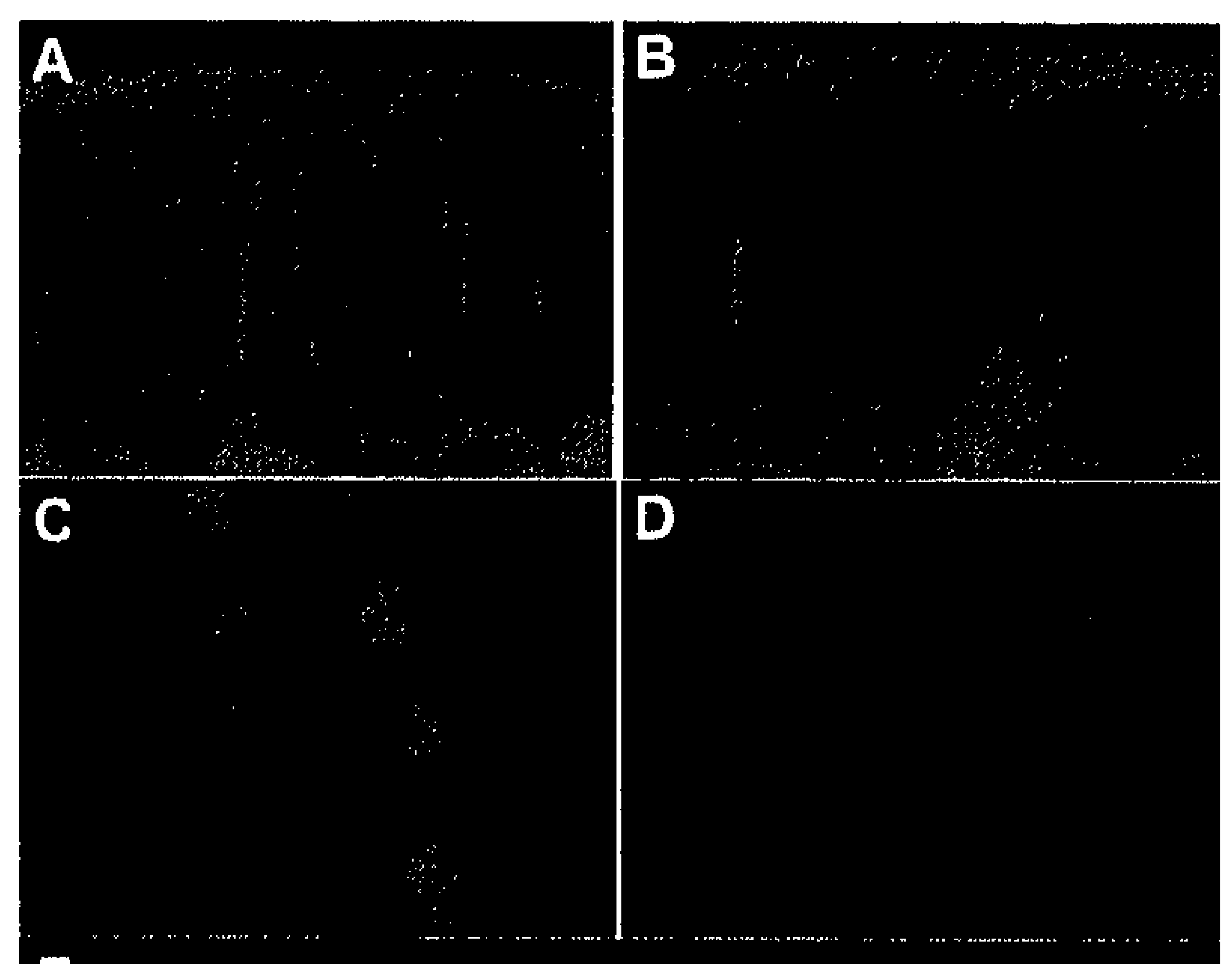

Figure 2: (A) Rabbit cartilage decalcified with 10\% EDTA and stained with DAPI. Note the retention of DNA. (B) Rabbit cartilage after decalcification with of the diluted TBD-1 solution and DAPI staining. Note the loss of DNA. ( C and D) Enlargements of (A) and (B), respectively. (E) Rabbit articular cartilage after decalcification with 10\% EDTA and incubation with DNAse and TUNEL assay (positive control). A and B X 50; C and D, X 400; E, X 100.

E See page 145 for colour figure.

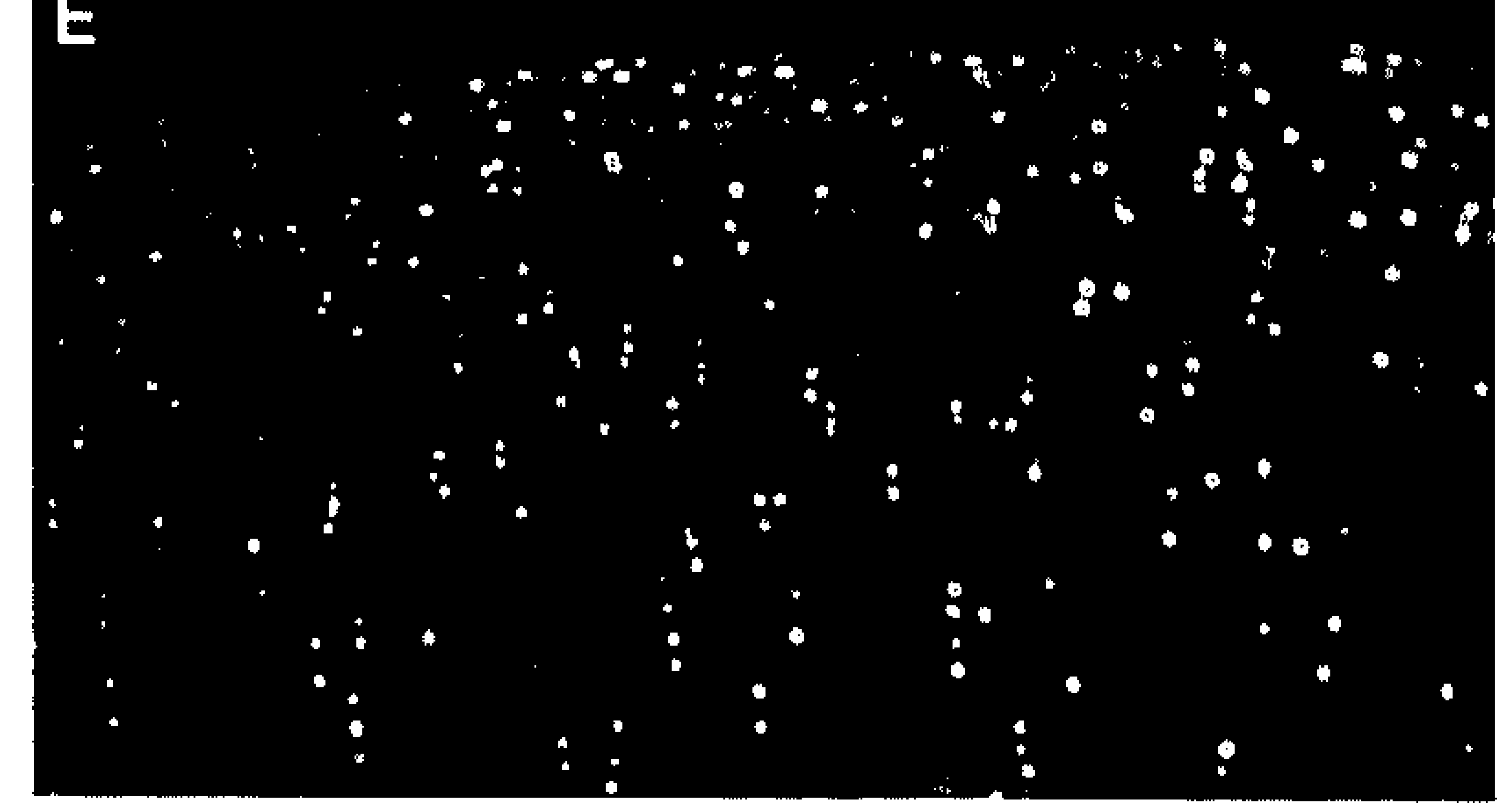

\section{General staining}

Thionine and H\&E staining staining were used to assess the morphological effects of the different decalcification protocols on cartilage. General staining protocols for thionine and $H \& E$ staining were used for both paraffin and GMA sections. The morphology and staining intensities were graded as $(-)$ negative, $(+)$ weak, $(++)$ moderate or $(+++)$ intense. 


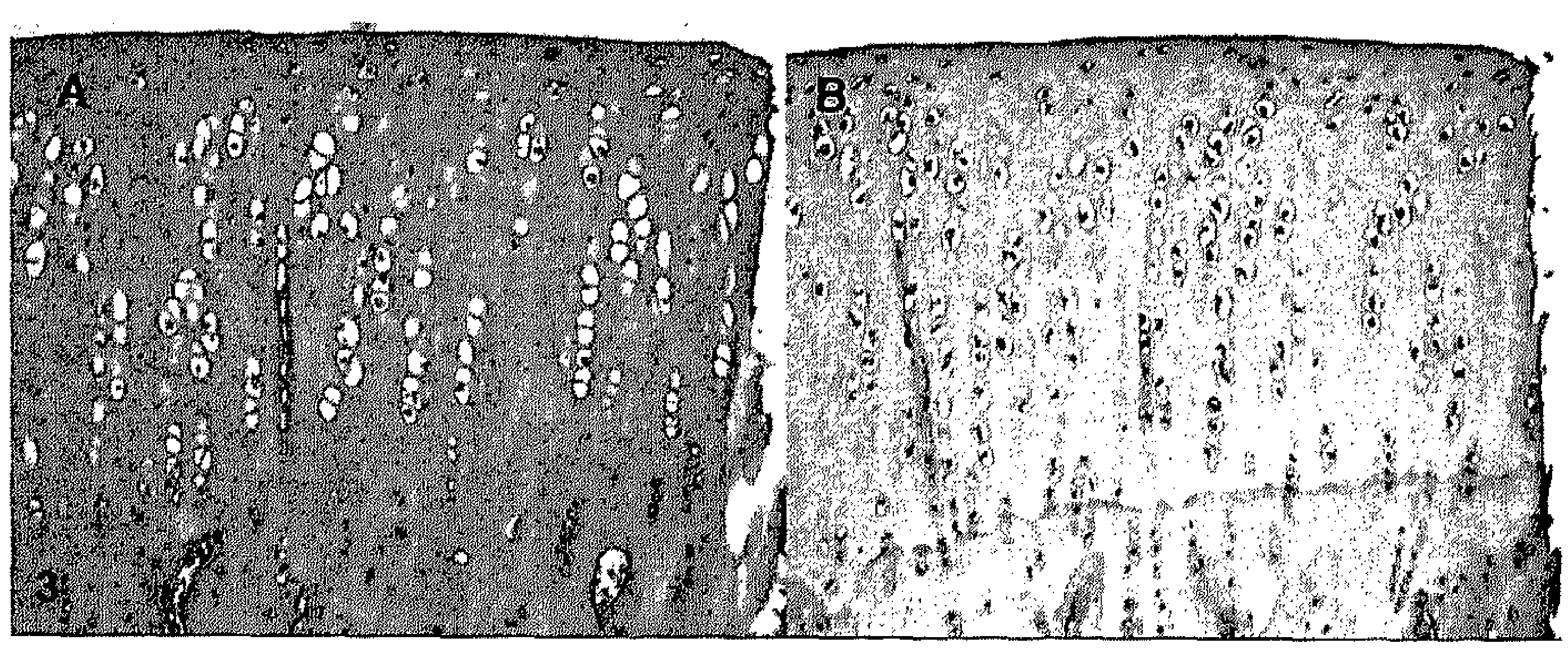

Figure 3: Rabbit articular cartilage with (A) and without (B) digestion with $20 \mathrm{mg} / \mathrm{mL}$ proteinase $K$. Note the difference in the number of nuclei present in (A) and (B). A and B, $50 \mathrm{X}$.

\section{Assessment of DNA}

DAPI staining was used to evaluate retention and integrity of DNA in GMA sections. Sections were incubated for 10 minutes at room temperature using 10 $\mu \mathrm{g} / \mathrm{mL}$ DAPI (Roche Applied Science, Almere, The Netherlands) in $0.2 \mathrm{mM}$ Tris- $\mathrm{HCl}(\mathrm{pH} 8.0)$. Staining intensity was examined by fluorescence microscopy and graded as $(-)$ negative, $(+)$ weak, $(++)$ moderate or $(+++)$ intense.

Terminal deoxy(d)-UTP nick end labeling and proteinase K pretreatment The principle of the TUNEL assay is localization of newly synthesized $3^{\prime} \mathrm{OH}$ DNA strand breaks. Fluorescein labeled deoxyuridine triphosphate (dig-dUTP) is incorporated into a template-independent tail at the 3'-OH end of double or single stranded DNA by means of the enzyme terminal deoxynucleotidyl transferase (TdT). To determine whether the TUNEL assay is applicable after different decalcification protocols, new 3'-OH ends were generated by incubating the sections with $0.01 \mathrm{U} / \mu \mathrm{L}$ DNAse for 15 minutes at room temperature. This protocol results in positive TUNEL staining in all cells. Sections of articular cartilage not incubated with DNAse and of cartilage subjected to the protocol in which $\mathrm{TdT}$ was omitted served as negative controls.

The rate of apoptosis is very low in normal articular cartilage ${ }^{7}$. The procedure was as follows: sections were dewaxed, hydrated until $70 \%$ ethanol and washed in phosphate buffered saline (PBS) for 5 minutes. The sections then were incubated in 132:66:2 methanol:chloroform:acetic acid (methacarn) solution for $15 \mathrm{~min}$ at room temperature. The proteinase $\mathrm{K}$ digestion was omitted (see below). Endogenous peroxidase was blocked by incubating the sections in $0.5 \% \mathrm{H}_{2} \mathrm{O}_{2}$ in PBS and washing twice for 5 min each in PBS. Some sections were incubated with $0.01 \mathrm{U} / \mu \mathrm{l}$ DNase I in $0.5 \mathrm{mM}$ Tris-Cl, $0.1 \mathrm{mM} \mathrm{MnCl}, 50$ $\mu \mathrm{g} / \mathrm{mL}$ bovine serum albumine (BSA), $\mathrm{pH} 7.5$ for 15 minutes at room tempera- 
ture and washed with PBS twice for $5 \mathrm{~min}$ each (positive controls). All sections were subsequently incubated with equilibration buffer $(0.2 \mathrm{M}$ Sodium cacodylate, $0.25 \mathrm{mM}$ Tris-Cl, $0.25 \mathrm{mg} / \mathrm{ml} \mathrm{BSA}, 0.3 \mathrm{mM} \mathrm{CoCl}, \mathrm{pH}=6.6$ ) for 10 minutes at RT and then with $0.03 \mathrm{U} \mathrm{TdT}, 0.04 \mathrm{nmol} / \mu \mathrm{L}$ Aluorescein-labeled dUTP, $25 \mathrm{mM} \mathrm{CoCl} 2$ in equilibration buffer for 30 minutes at $37^{\circ} \mathrm{C}$ in a humidified incubation box. During equilibration and TdT incubation, the sections were covered with hand-made plastic coverslips. The TdT reaction was stopped by washing the sections in $300 \mathrm{mM} \mathrm{NaCl}, 30 \mathrm{mM}$ sodium citrate solution for 30 minutes at $37^{\circ} \mathrm{C}$. Coverslips were mounted using Immunomount. Staining intensities were examined by fluorescence microscopy and graded as before.

To examine the effect of proteinase $\mathrm{K}$ on preservation of nuclei and to exclude the possible effects of the decalcification agent, non-decalcified cartilage sections were incubated with methacarn fixative ${ }^{8}$ followed by incubation with either 5,10 or $20 \mathrm{ug} / \mathrm{mL}$ proteinase $\mathrm{K}$ for 20 minutes at room temperature. Subsequently, the sections were washed three times with PBS and stained with hematoxylin. The percentage of cells without nucleus was examined by light microscopy.

\section{RESULTS AND DISCUSSION}

It is difficult to prepare histological sections of articular cartilage. To get a good histological perspective and also to judge the tidemark and calcified cartilage layer, it is important to leave a piece of subchondral bone attached. Therefore decalcification of the samples is an important step in the histological procedure. Several decalcifying agents are available to address different purposes.

The time required for decalcification determined by soft $\mathrm{X}$-ray analysis varied from one day for half the concentration of TBD-1 to more than 80 days for $5 \%$ acetic acid (Table 2).

Decalfication with 10\% EDTA resulted in the best matrix and nucleus staining of cartilage for both $\mathrm{H} \& \mathrm{E}$ and thionine staining (Fig. 1A, C). Generally, staining after decalcification with 10\% citric acid and half the concentration of TBD-1 was weak (Fig. 1B, D; Table 2).

DNA retention was weak to absent in the cartilage of samples decalcified with half the concentration of TBD-1 and samples decalcified with 5\% acetic acid. By contrast, DNA in chondrocytes was conserved if the tissue was decalcified with 10\% EDTA (Fig. 2A-D; Table 2).

TUNEL staining was only tested on the samples in which DNA was retained. TUNEL staining was not applicable if cartilage was decalcified with 5\%TCA; however, intensively positive TUNEL staining was possible after 
TUNEL and cartilage staming

Table 2: Time required for decalcification and intensity grading for the different staining protocols.

\begin{tabular}{llllll}
\hline $\begin{array}{lllll}\text { Decalcification } \\
\text { solution }\end{array}$ & $\begin{array}{l}\text { Decalcification } \\
\text { period (days) }\end{array}$ & Matrix & Nucleus & & Thionine \\
$10 \%$ EDTA & 45 & ++ & +++ & Matrix \\
\hline $10 \%$ Citric acid & 31 & ++ & ++ & +++ \\
$5 \%$ TCA acid & 8 & ++ & + & + \\
$5 \%$ Acetic acid & 80 & ++ & +++ & ++ \\
TBD-1 & 1 & ++ & + & ++ \\
\hline
\end{tabular}

decalcification with 10\% EDTA even if the sections were incubated with methacarn (Fig. 2E). These results indicate that decalcification with 10\% EDTA is the preferred decalcification protocol for producing a reliable TUNEL assay (Table 2).

Although highly variable and possibly also dependent on fixation of the tissue, digestion with $20 \mu \mathrm{g} / \mathrm{mL}$ proteinase $\mathrm{K}$ caused up to $80 \%$ loss of chondrocyte nuclei (Fig. 3A). Hypertrophic cells especially were vulnerable for proteinase induced nucleus loss. This percentage decreased with concentration of proteinase $\mathrm{K}$. In both methacarn and untreated sections, $10-15 \%$ of the cells lacked a nucleus (Fig. 3B). Others have reported that the signal to noise ratio is proteinase $\mathrm{K}$ dependent ${ }^{9}$. Therefore, investigators have suggested that proteinase $\mathrm{K}$ might contribute to the highly variable amount of apoptosis in osteoarthritic cartilage in reports based on the TUNEL assay ${ }^{7,10-13}$. Awareness of the adverse affects of proteinase $\mathrm{K}$ digestion for TUNEL assays in cartilage is of critical importance.

\section{Acknowledgements}

This study was supported by grant BTS00021 from Senter, Ministry of Economic Affairs, The Netherlands. The help of May Bost, Petra Dijkstra and Joyce Suyk with the experimental animals and the X-ray measurements is gratefully acknowledged.

\section{REFERENCES}

1. Alers JC, Krijtenburg PJ, Vissers KJ, van Dekken H. Effect of bone decalcification procedures on DNA in situ hybridization and comparative genomic hybridization. EDTA is highly preferable to a routinely used acid decalcifier.J Histochem Cytochem 1999; 47(5): 703-10.

2. Arber JM, Weiss LM, Chang $\mathrm{KL}$, Battifora $\mathrm{H}$, Arber DA. The effect of decalcification on in situ hybridization. Mod Pathol 1997; 10(10): 1009-14.

3. Gavrieli Y, Sherman Y, Ben-Sasson SA. Identification of programmed cell death in situ via specific labeling of nuclear DNA fragmentation. J Cell Biol 1992;119(3): 493-501. 
Chapter 3

$44 \mid$

4. Hashimoto S, Koji T, Niu J, Kanematsu T, Nakane PK. Differential staining of DNA strand breaks in dying cells by non-radioactive in situ nick translation. Arch Histol Cytol 1995; $58(2): 161-70$

5. Kaneko $\mathrm{H}$, Ogiuchi $\mathrm{H}$, Shimono $\mathrm{M}$. Cell death during tooth eruption in the rat: surrounding tissues of the crown. Anat Embryol (Berl) 1997; 195(5): 427-34.

6. Sakai T, Kiyoshima T, Kobayashi I, Moroi R, Ibuki T, Nagadome M, et al. Age-dependent changes in the distribution of BrdU- and TUNEL-positive cells in the murine gingival tissue.J Periodontol 1999; 70(9): 973-81.

7. Aigner T, Hemmel M, Neureiter D, Gebhard PM, Zeiler G, Kirchner T, et al. Apoptotic cell death is not a widespread phenomenon in normal aging and osteoarthritis human articular knee cartilage: a study of proliferation, programmed cell death (apoptosis), and viability of chondrocytes in normal and osteoarthritic human knee cartilage. Arthritis Rheum 2001; 44(6): 1304-12.

8. Puchtler H, Waldrop FS, Mcloan SN, Terry MS, Conncr HM. Mcthacarn (methanolCarnoy) fixation. Practical and theoretical considerations. Histochemie 1970;21(2):97-116.

9. Yamamoto-Fukud T, Shibata Y, Hishikawa Y, Shin M, Yamaguchi A, Kobayashi T, et al. Effects of various decalcification protocols on detection of DNA strand breaks by terminal dUTP nick end labelling. Histochem J 2000; 32(11): 697-702.

10. Blanco FJ, Guitian R, Vazquez-Martul E, de Toro FJ, Galdo F. Osteoarthritis chondrocytes die by apoptosis. A possible pathway for osteoarthritis pathology. Arthritis Rheum 1998; 41(2): 284-9.

11. Hashimoto S, Ochs RL, Komiya S, Lotz M. Linkage of chondrocyte apoptosis and cartilage degradation in human osteoarthritis. Arthritis Rheum 1998; 41(9): 1632-8.

12. Kim HA, Lee YJ, Seong SC, Choe KW, Song YW. Apoptotic chondrocyte death in human osteoarthritis. J Rheumatol 2000; 27(2): 455-62.

13. Kouri JB, Aguilera JM, Reyes J, Lozoya KA, Gonzalez S. Apoptotic chondrocytes from osteoarthrotic human articular cartilage and abnormal calcification of subchondral bone. $J$ Rheumatol 2000;27(4): 1005-19. 


\section{4 \\ Variable chondrogenesis of aged human periosteal cells; effects of growth factors on proliferation and differentiation.}

Edwin JP Jansen, Pieter J Emans, Martine M Hulsbosch, Mireille Schrooten-van Helden, Don AM Surtel, Sjoerd K Bulstra, Roel Kuijer.

2006; Submitted 


\section{ABSTRACT}

The aim of this study is to assess the chondrogenic potential and optimize the proliferation of aged human periosteal derived cells using different growth factors and culture media.

Periosteum-derived cells from the proximal tibia of aged human donors were enzymatically released and expanded in DMEM/F12 or MEM(D)valine. Presence and thickness of the cambium layer was controlled in each aged patient and in 3 young donors. After multiple passages, cells were isolated and their chondrogenic potential was tested. In micromass or alginate chondrogenesis assays cells were differentiated using TGF $-\beta$ isomers, IGF-1 or a combination. Samples were analyzed for Collagen Type I, II and X expression by quantitative RT-PCR or by immunohistochemical staining for Collagen Type I and II, and Thy-1 (fibroblast marker). Foetal Bovine Serum. (FBS) or serum replacements and growth factors were added to MEM(D)valine to study their effect on cell proliferation.

Only after expansion in MEM(D)-valine, chondrogenesis was detected. Chondrogenesis was detected in $59 \%$ of samples using a micromass assay. The highest Collagen Type II expression (>50pg) was found if cells were differentiated in alginate supplemented with DMEM/F12, 1\% ITS, AA-2-P with TGF- $\beta_{3}$. Collagen Type II staining was also only positive using these conditions. In contrast to young donors, the cambium layer of aged patients was much thinner and could hardly be detected. For cell proliferation FBS supplementation was essential, addition of FGF-2 enhanced cell proliferation

Cells isolated from periosteum of aged patients have chondrogenic potential after expansion in MEM(D)-valine. FBS is essential for cell proliferation and MEM(D)-valine seems to inhibit fibroblast overgrowth. Multiple factors may contribute to the variable chondrogenic potential of aged periosteum, amongst others a thin to absent cambium layer. This variability must be taken into consideration when periosteum is considered as a chondrogenic cell

\section{INTRODUCTION}

Articular cartilage lesions fail to heal spontaneously and even may evolve to premature osteoarthritis $(\mathrm{OA})^{1,2}$. The current surgical treatment options to repair damaged articular cartilage lesions are debridement and lavage, with subsequent microfracturing or drilling of the subchondral bone ${ }^{3,4}$. Alternative treatment options have been explored, such as autologous perichondrium transplantation $^{5-7}$ and osteochondral autograft transplantation ${ }^{8,9}$. In both autologous 
Variable chondrogenesis of aged human periosteal a.

chondrocyte transplantation (ACT) ${ }^{10,11}$ and autologous periosteum transplantation a periosteal explant is used ${ }^{12-14}$. After autologous periosteum transplantation, ideally, mesenchymal stem cells in the periosteum differentiate into a chondrogenic lineage and produce hyaline cartilage when transferred into the cartilage defect. The main limitation of this technique is the variability in cartilage produced by the transplanted periosteum. Recent research is focused on restoring the joint surface using biomaterials. In general, scaffolds are seeded in vitro with expanded cells, which are implanted in the cartilage lesion. Either mature chondrocytes or mesenchymal stem cells can be used as cell source. Mature chondrocytes usually are obtained from cartilage of a less load-bearing region of the affected joint. Little is known about the fate of the donor site; additional injury to the joint surface might contribute to preliminary $O A$. Therefore an extra-articular cell source night be less harmful. It is well established that periosteum is a source of chondrogenic precursor cells ${ }^{15-17}$. The undifferentiated mesenchymal stem cells reside in the cambium layer and are essential for both osteogenesis and chondrogenesis ${ }^{15-21}$. The main limitation in using periosteum as a chondrogenic tissue from adult patients is the variability in quantity and quality of the produced cartilage. In rabbits, the chondrogenic capacity of periosteum diminishes with age, as a consequence of the declining number of stem cells in the cambium layer ${ }^{22}$. Therefore in most in vitro studies periosteum of very young animals was used ${ }^{13,15,17,19-21}$. Only a few investigators were successful in culturing young human periosteal-derived cells in monolayer 19. 23. In contrast, it has been reported that the chondrogenic potential of periosteum was maintained in the aged patient, making this a potential alternative source of progenitor cells for cartilage repair ${ }^{24}$. The aim of the present study was to investigate whether periosteal-derived cells from aged people could serve as a cell source for cartilage repair. In addition, we examined which growth factors or nutrients could enhance proliferation and chondrogenic differentiation of periosteal cells.

In Minimum essential medium D-valine (MEM(D)-valine), L-valine is substituted for D-valine, which inhibits fibroblast growth due to the absence of Damino acid oxidase in fibroblasts. Originally this medium was developed to facilitate the growth of normal epithelial cells while selectively inhibiting the proliferation of fibroblasts in cell culture ${ }^{25}$. MEM(D)-valine medium has been used in a variety of cell cultures ${ }^{26-29}$, but was never described as a selective medium in culturing periosteal-derived cells. Theoretically the fibroblasts of the fibrous layer may overgrow the chondrogenic progenitor cells of the cambium layer. We examined whether this medium could be used for periosteal-cell expansion and if chondrogenesis was enhanced. 
Chinter 4

48

\section{MATERIAL AND METHODS}

Periosteum harvest and cell isolation

A 1-2 $\mathrm{cm}^{2}$ sample of periosteum from patients having a knee arthrotomy was isolated from the anteromedial site of the proximal tibia by sharp dissection. In order to examine the presence of the cambium layer, one small piece was fixated in $4 \%$ formaldehyde overnight and embedded in paraffin. Routine $\mathrm{H} \& \mathrm{E}$ staining was used to visualize a cambium layer in periosteum. The remaining big part of the periosteal explant was immediately placed in tubes containing phosphate buffered saline (PBS) supplemented with penicillin $(500 \mathrm{U} / \mathrm{mL})$, streptomycin $(500 \mu \mathrm{g} / \mathrm{mL}$ ) and $0.25 \mu \mathrm{g} / \mathrm{mL}$ amphotericin B (Invitrogen, Breda, The Netherlands). The periosteum was cut into small pieces using a scalpel and medium was discarded. After rinsing, the periosteum was incubated for 3 hours at $37^{\circ} \mathrm{C}$ in a shaking water bath in $5 \mathrm{~mL}$ DMEM-Hepes medium. (Invitrogen, Breda, The Netherlands) containing $300 \mathrm{U} / \mathrm{mL}$ collagenase type II (Invitrogen, Breda, The Netherlands). The periosteal tissue samples were transferred into T25 cell culture flasks (Corning, The Netherlands) containing Dulbecco's Modified Eagle's Medium (DMEM)/Ham's F12 nutrient mix (Invitrogen, Breda, The Netherlands), supplemented with $10 \%$ fetal bovine serum (FBS) (Invitrogen, Breda, The Netherlands), $500 \mathrm{U} / \mathrm{mL}$ penicillin, $500 \mathrm{U} / \mathrm{mL}$ streptomycin and $0.25 \mu \mathrm{g} / \mathrm{mL}$ amphotericin B. Periosteal cells were allowed to grow out of the tissue. After 10 days the periosteal tissue was removed and discarded.

A very small piece of periosteum of 3 young patients (mean age, 6 years), undergoing a epiphysiodesis using a staple technique, was harvested approximately $1.5-2 \mathrm{~cm}$ caudally from the proximal tibial growth plate. The tissue was prepared for sections as described above, and $\mathrm{H} \& \mathrm{E}$ staining was used to visualize the cambium layer.

\section{Cell expansion}

Periosteum samples from 12 patients ( 10 females and 2 males) were investigated. The age of the patients at time of operation ranged from $19-76$ years (mean age, 62 years; SD, 17 years). At $80 \%$ confluent, cells were detached from the flask using a trypsin/EDTA solution (Invitrogen, Breda, The Netherlands) and subcultures were continued in monolayer in (i) MEM(D)-valine (Cell Culture Technologies, Germany), supplemented with 10\% FBS, 2 mM Glutamax (Invitrogen, Breda, The Netherlands), and antibiotics or (ii) in DMEM/F12 supplemented with 10\% FBS, 2 mM Glutamax (Invitrogen, Breda, The Netherlands), and antibiotics. The medium was refreshed every three days. Chondrogenic differentiation experiments started after an average of 7 passages (range, 4-11; SD, 2). 
Variable chondrogenesis of aged human periosteal cells

In vitro alginate chondrogenesis assay

Periosteal cells of 5 patients were trypsinized, isolated and suspended in a sterile $1.2 \%$ alginate (high viscosity, Keltone), $0.9 \% \mathrm{NaCl}$ solution at $4 \times 10^{6}$ cells $/ \mathrm{mL}$. The age at the time of operation ranged from $19-75$ years (mean age, 58 years; $\mathrm{SD}, 23$ years). Subsequently the suspension was dropped through a $21 \mathrm{G}$ needle in a sterile solution of $102 \mathrm{mM} \mathrm{CaCl}_{2}, 0.9 \% \mathrm{NaCl}$. The resulting beads were washed and then divided over several wells of a 6-wells plate and cultured in (i) DMEM/F12 nutrient mix supplemented with 1\% Insulin-Transferrin-Selenium (ITS), $2 \mathrm{mM}$ Ascorbic acid-2-phosphate (AA-2-P) (Sigma) and $5 \mathrm{ng} / \mathrm{mL}$ Transforming growth factor- $\beta_{3}$ (TGF- $\left.\beta_{3}\right)$ (R\&D, Uithoorn, The Netherlands), or (ii) DMEM (Invitrogen, Breda, The Netherlands) with 1\% ITS and 1-3-5-8$10 \mathrm{ng} / \mathrm{mL}$ TGF- $\beta_{3}$ or $3-10-30-100-300 \mathrm{ng} / \mathrm{mL}$ IGF-1. ITS was selected as a medium supplement because it was shown to be effective in stimulating glycosaminoglycan synthesis in cultured chondrocytes ${ }^{30}$ and to facilitate growth of rat foetal periosteal cells ${ }^{31}$. Controls were beads cultured in differentiation medium without growth factors. Medium was refreshed two times each week. Alginate beads with cells were maintained in culture for 3 weeks and subsequently were dissolved in a sodium citrate solution $(150 \mathrm{mM} \mathrm{NaCl}, 55 \mathrm{mM}$ sodium citrate, $20 \mathrm{mM}$ EDTA). Cells were collected by centrifugation and suspended in PBS. Then, cytospins were prepared for immunohistochemistry or cells were collected for total RNA isolation.

In vitro micromass chondrogenesis assay

Periosteal cells from 8 patients were cultured in micromasses as described elsewhere ${ }^{24}$. The age at time of operation ranged from $40-76$ years (mean age, 64 years; SD, 13 years). Micromass cultures were prepared by suspending expanded and trypsinized cells in differentiation medium at a density of $4 \times 10^{5}$ cells $/ \mathrm{mL}$, pipetting $1 \mathrm{~mL}$ of cell suspension in conical centrifuge tubes at $200 \mathrm{x}$ g for 4 min. The resulting micromasses were cultured in DMEM, supplemented with $1 \%$ ITS and $2 \mathrm{mM}$ AA-2-P. Various growth factors alone or in different combinations $\left(300 \mathrm{ng} / \mathrm{mL}\right.$ IGF- $1,5-10 \mathrm{ng} / \mathrm{mL}$ TGF- $\beta_{1}, 5-10 \mathrm{ng} / \mathrm{mL}$ TGF- $\beta_{2}, 10$ $\mathrm{ng} / \mathrm{mL}$ TGF- $\beta_{3}$ ) were added. Controls were micromasses cultured in differentiation medium without growth factors. Human embryonic lung fibroblasts (HELF) were cultured in micromass and served as cell type control. Micromass cultures were maintained for 3 weeks. Medium was refreshed two times each week. At the end of the culture period, medium was removed and a minimum of 6 micromasses was collected for isolation of total RNA. Besides cryosections were prepared for immunohistochemistry or stained with Alcian Blue. 
$R N A$ isolation and competitive $R T-P C R$

Total RNA was isolated using TriZol ${ }^{\mathrm{TM}}$ (Invitrogen, Breda, The Netherlands) according to the instruction of the manufacturer. The competitive RT-PCR method has been described previously ${ }^{32}$. In brief, genomic DNA was removed from the samples by RNase-free DNase I digestion (Roche, Woerden, The Netherlands). Absence of genomic DNA was controlled with a PCR using specific primers for glyceraldehyde-3-phosphate dehydrogenase (GAPdH). Different dilutions of standard RNA were added to equal samples of total RNA. Two hundred nanograms of heat denatured $\left(6 \mathrm{~min}, 72^{\circ} \mathrm{C}\right)$ and standard RNA were reverse transcribed during $1 \mathrm{~h}$ at $37^{\circ} \mathrm{C}$ using $100 \mathrm{U}$ Moloney murine leukemia virus (M-MLV) reverse transcriptase (Promega Corporation, Leiden, The Netherlands) in $50 \mathrm{mM}$ Tris- $\mathrm{HCl}$ (pH 8.3), $75 \mathrm{mM} \mathrm{KCl}$ and $3 \mathrm{mM} \mathrm{MgCl}$ and $10 \mathrm{U}$ RNAsin (Promega, WI, USA) and random hexamer primers (Promega). Two $\mu \mathrm{L}$ c-DNA from each resulting sample were amplified in $10 \mu \mathrm{L}$ PCR reaction mixture with primers for either Collagen Type I, II or X at an annealing temperature of $66^{\circ} \mathrm{C}$ and a magnesium concentration in the PCR buffer of $0.7 \mathrm{mM}$. Primer sets for Collagen Type II and X were obtained from the literature ${ }^{33,34}$ or were selected from the sequences of the cDNA obtained from Genbank (GAPdH, Collagen Type I and Type X (Table 1)). Eight $\mu \mathrm{L}$ of each PCR product were subjected to $2 \%$ agarose gel electrophoresis with 0.5 $\mathrm{mg} / \mathrm{mL}$ ethidium bromide (Invitrogen, Breda, The Netherlands) and DNA bands were visualized. Images of the gels were digitized using conditions in which bands were not saturated, and the bands were quantified using Geldoc 1000 system using Multi-Analist software (Bio-Rad, CA, USA).

Table 1. Primer sequences for GAPdH, Collagen type I, Collagen type II and Collagen type X.

\begin{tabular}{|c|c|c|c|c|}
\hline cDNA & Size (bp) & & Primer sequence & Genbank accession \\
\hline GAPdH & 235 & as & $\begin{array}{l}\text { 5"-CGGCCATCACGCCACAGTTT-3" } \\
\text { 5'-TGCTGATGCCCCCATGTTCG-3' }\end{array}$ & BCo83511 \\
\hline Collagen Type I & 552 & as & $\begin{array}{l}\text { 5'-GGCCACGCTGTTCTTGCAGT-3' } \\
\text { 5'-CCAGCGCTGGTTTCGACTTC-3' }\end{array}$ & 274615 \\
\hline Collagen Type II & 492 & a & $\begin{array}{l}\text { 5'-GAAAAGATGGTCCCAAAGGTGC-3' } \\
\text { 5'-TGTCTCCTTGCTTGCCAGTTGG 3' }\end{array}$ & \\
\hline Collagen Type X & 329 & as & $\begin{array}{l}\text { 5:-ACAGGAATGCCTGTGTCTGCTIIT-3' } \\
5^{\prime} \text {-TTGGGAAGCTGGAGCCACACCTGGTC } 3\end{array}$ & AY598937 \\
\hline
\end{tabular}


Variable chondrogenesis of aged humin periostesl cells

\section{Immunohistochemistry}

To confirm differential expression of Collagen Types I and II at the protein level, immunohistochemistry was performed on cytospins and cryosections using specific antibodies. Cytospins were fixated in acetone for $15 \mathrm{~min}$ at $4^{\circ} \mathrm{C}$, washed $3 \times 5 \mathrm{~min}$ in PBS and pre-incubated in PBS containing 20\% FBS for $10 \mathrm{~min}$. Primary antibodies used were M-38 (anti-procollagen type I) at 1:50 (Developmental Studies Hybridoma bank (DSHB), Iowa University, Iowa), II-II6B3 (anti-collagen type II) at 1: 50 (DSHB), and Thy-1 (anti-CD90, fibroblast marker) at 1:250 (Brunschwig Chemie, Amsterdam, The Netherlands). Secondary antibody was Rabbit anti-mouse immunoglobulin $G$ conjugated with horseradish Peroxidase (HRP) at 1:200 (DAKO, Glostrup, Denmark. The secondary antibody was detected using 3.3-diaminobenzidine (DAB) (Merck, Darmstadt, Germany).

\section{Proliferation assay}

Periosteal-derived cells from two patients were seeded in wells (1000 cells per well). Culture medium was MEM(D)-valine containing L-glutamine (2 $\mathrm{mM})$, penicillin $(500 \mathrm{U} / \mathrm{mL})$ and streptomycin $(500 \mu \mathrm{g} / \mathrm{mL})$. The cells were allowed to attach during one day. Cells from patient 1 (woman, 76 years of age) were expanded in medium containing $10 \%$ FBS or $1 \%$ ITS. Non-essential aminoacids (NEAA), proline (1nM) (Invitrogen, Breda, The Netherlands), 10 $\mathrm{ng} / \mathrm{mL}$ fibroblast growthfactor-2 (FGF-2) or $300 \mathrm{ng} / \mathrm{mL}$ insulin-like growth factor-1 (IGF-1) (R\&D, Uithoorn, The Netherlands) or combinations were added to the culture media. Culture media containing FBS or ITS, but without other supplements, were used as control.

To periosteal cells from patient 2 (woman, 62 years of age) were added: (i) FGF-2 in a concentration of $10 \mathrm{ng} / \mathrm{mL}$ or $100 \mathrm{ng} / \mathrm{mL}$; (ii) IGF-1 in a concentration of $10 \mathrm{ng} / \mathrm{mL}$ or $300 \mathrm{ng} / \mathrm{mL}$ or (iii) bovine serum albumin (BSA) (Sigma Aldrich) with ITS, or (iv) BSA with Ultroser ${ }^{\mathbb{B}} \mathrm{G}$ (Invitrogen, Breda, The Netherlands). MEM(D)-valine with $10 \%$ FBS, but without FGF-2, IGF-1 or NEAA was used as control. Media were refreshed at days 4, 7 and 11. In the first study cells were harvested on days $1,6,8,11$ and 14 ; in the second study on days 1,6 , 11 and 14. Cells were counted by determining the DNA content using the CyQUANT DNA Assay kit (Molecular Probes, Leiden, The Netherlands).

\section{RESULTS}

The cambium layer in the aged patient is thinner than in the young patient.

The technique of harvesting periosteum seemed appropriate, since in all young patients an evident cambium layer was detected. In contrast, a cambium 


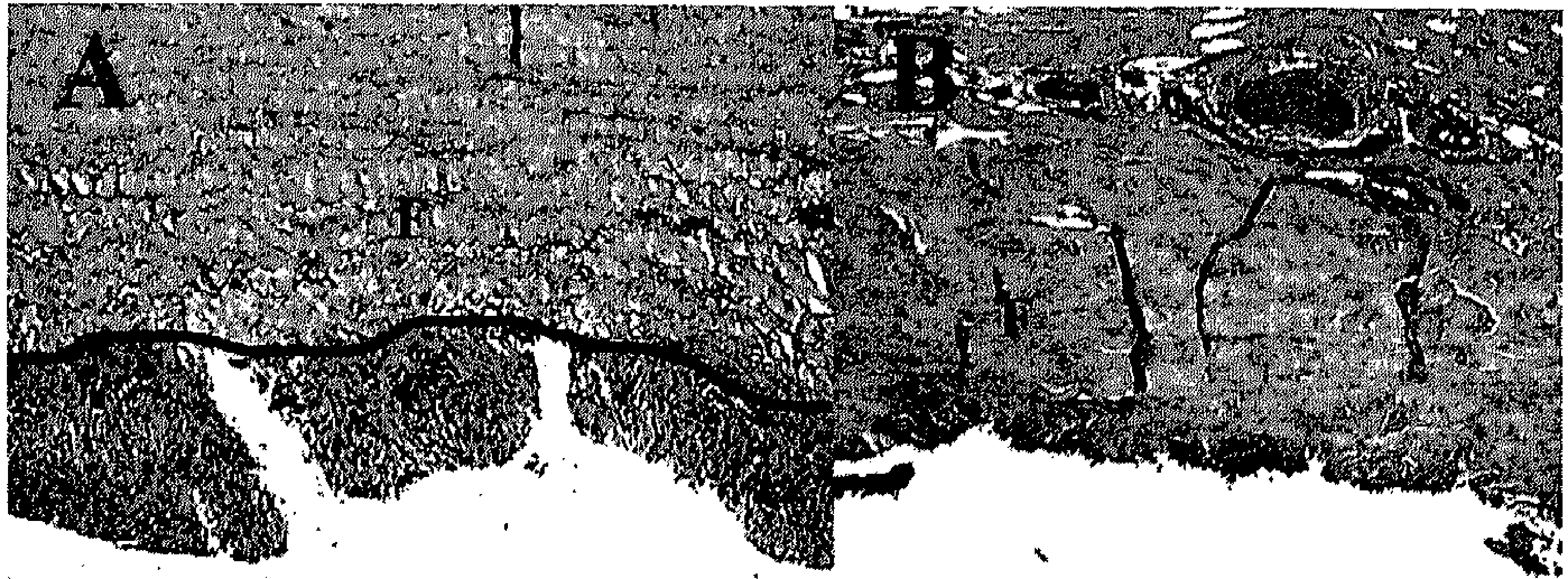

Figure 1. Micrographs of periosteum harvested from the proximal tibia of $\mathrm{A}$ ) a young patient (age, 5 years) and B) an aged patient (age, 62 years). Notice the clearly distinguishable cambium layer $(c)$ in the periosteum derived from the young patient and the hardly detectable cambium layer in the periosteum from the aged patient. The overlying fibrous layer (f) contains fibroblasts. Magnification: 50x.

layer was hard to distinguish in the older patient. $H \& E$ staining showed that the cambium layer in the young patient is multiple cell layers thick. None or single cell layer thick cambium was found in most aged patients (Figure 1).

Periosteum from aged patients expand in MEM-(D valine) and show a variable chondrogenic potential

In vitro alginate chondrogenesis assay

Twenty-four samples were cultured in DMEM and 1\% ITS. To 11 samples different concentrations TGF- $\beta_{3}$ were added; to 10 samples different concentrations of IGF-1. To 3 samples no growthfactors were added. In the absence of growthfactors, mRNA expression for Collagen Type II was never detected, whereas mRNA expression for Collagen Type I was detected in all and mRNA expression for collagen $X$ in 2 cases. Stimulation with $10 \mathrm{ng} / \mathrm{mL} \quad \mathrm{TGF}-\beta_{3}$ resulted in mRNA expression of Collagen Type II $(<50 \mathrm{pg}$ and $>500 \mathrm{fg})$ in one case ( 1 per 3 samples tested). Collagen Type II expression was never found with lower concentrations TGF- $\beta_{3}$ or IGF-1. However if DMEM was replaced with DMEM/F12 nutrient mix and AA-2-P $(n=2)$, a higher expression of Collagen Type II was detected $(>50 \mathrm{pg})$ with a lower $(5 \mathrm{ng} / \mathrm{mL})$ TGF- $\beta_{3}$ concentration. In contrast, if cells were expanded in DMEM/F12, instead of MEM-(D-valine), comparable concentrations of TGF- $\beta_{3}$ did not induce chondrogenesis ( $\mathrm{n}=3$; data not shown).

In accordance to the mRNA findings, a positive staining for Collagen Type II was only found when cells were expanded using MEM(D)-valine and differentiated in DMEM/F12 with TGF- $\beta$. All cytospins stained positive for Collagen Type I and the fibroblast marker Thy-1. However staining intensity of this fibroblast marker was lower in cells with a positive Collagen Type II staining. 

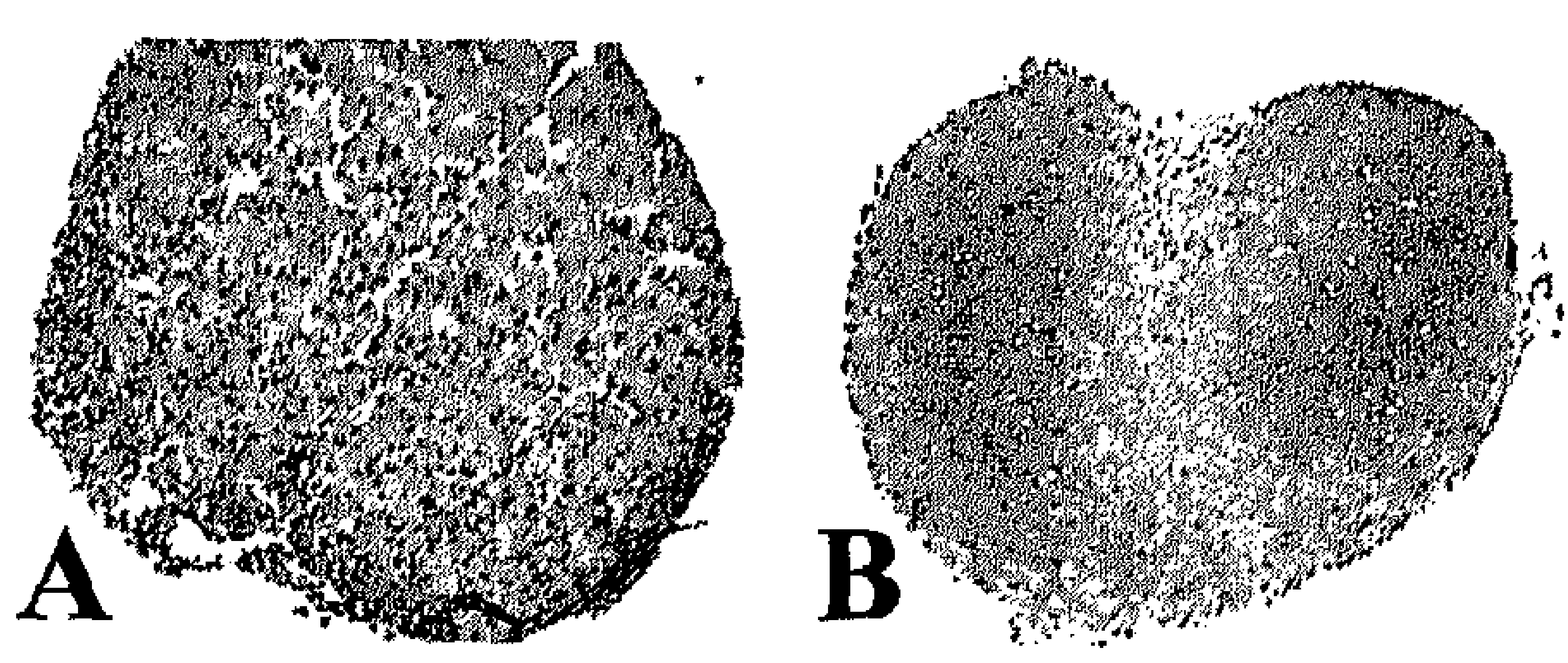

Figure 2. Micrographs of cryosections of micromasses after staining with Alcian blue (donor age was 62 years). Periosteal-derived cells were differentiated in medium A) without growth factors or medium supplemented with B) TGF- $\beta_{1}(10 \mathrm{ng} / \mathrm{mL})$ or C) TGF $-\beta_{3}(10 \mathrm{ng} / \mathrm{mL})$. Notice the zone of calcification in the micromass that was differentiated with TGF- $\beta_{3}$. Magnification: $50 \mathrm{x}$. See page 146 for colour figure.

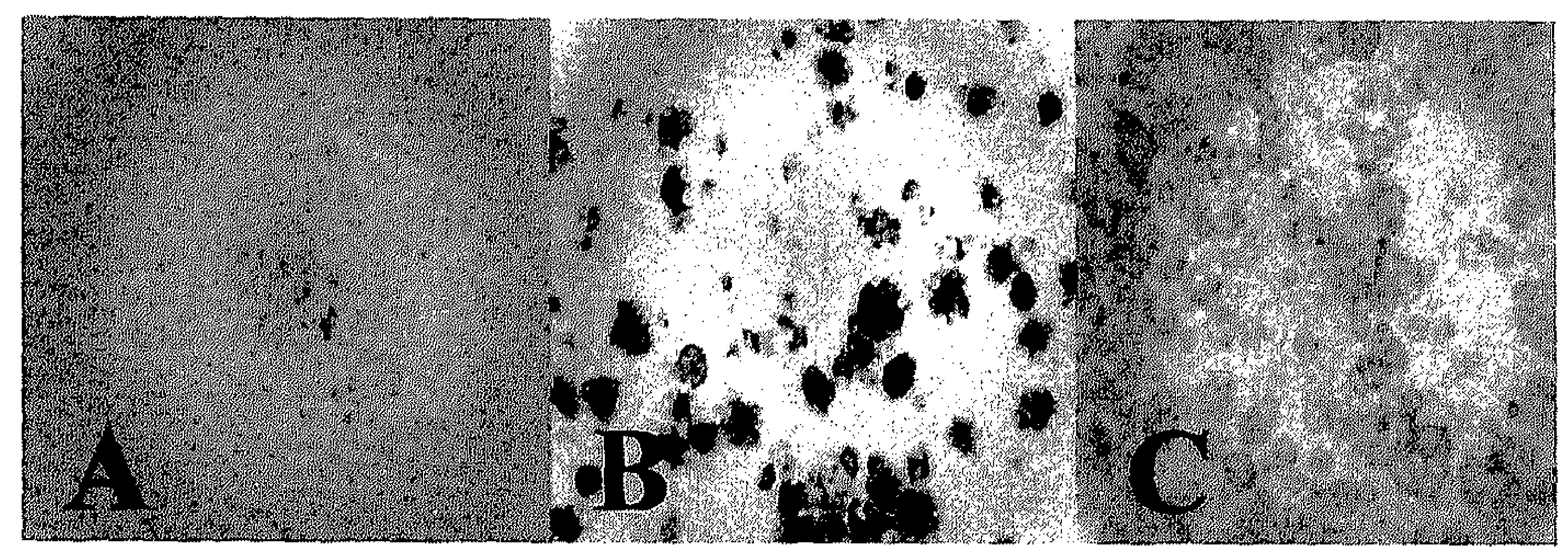

Figure 3, Micrographs of cytospins after immunocytochemical staining with antibodies A) M38; B) II-II6B3 and C) Thy-1 of periosteum-derived cells (donor age was 62 years). Differentiation medium was supplemented with TGF- $\beta_{3}$. Magnification $100 x$.

See page 146 for colour figure.

In vitro micromass chondrogenesis assay

Collagen Type II mRNA was expressed in 59\% (18/31) of cultures that were supplemented with growth factors and was in most cases higher than $500 \mathrm{fg}$. In one control sample (1/7) a low ( $<500 \mathrm{fg}$ ) mRNA expression for Collagen Type II was detected. Collagen Type II mRNA was not expressed in RNA from micromasses that were cultured in differentiation medium that was supplemented with $300 \mathrm{ng} / \mathrm{mL}$ IGF-1 but without TGF- $\beta$ isomers $(n=2)$. On the other hand, the addition of IGF-1 to TGF- $\beta$ isomers resulted in a higher percentage of samples that expressed Collagen Type II mRNA. Expression of Collagen Type I mRNA was detected in all samples and was confirmed by immunohistochemistry. Expression of Collagen Type X mRNA was detected in 6 of 7 control samples and in 27 of 31 growth factor-containing (TGF- $\beta$ isomers, IGF-1 or a combination of both) samples. In contrast to the alginate chondrogenesis assay, the amount of Collagen Type II expression was never higher than $50 \mathrm{pg}$ as observed in micromass experiments. 
54

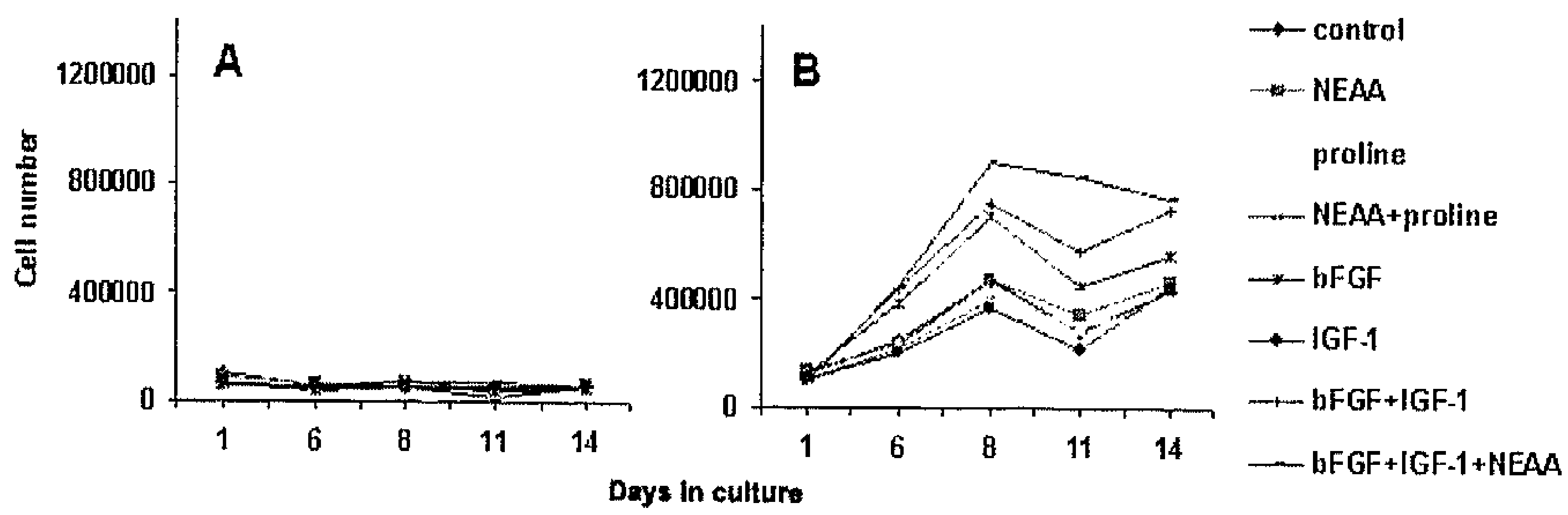

Figure 4. Number of periosteal-derived cells ${ }^{\star}$ after expansion in MEM (D)-valine supplemented with NEAA, $1 \mathrm{nM}$ proline, $10 \mathrm{ng} / \mathrm{mL}$ bFGF and $300 \mathrm{ng} / \mathrm{mL}$ IGF-1.

Proliferation mediun with serum-free medium (ITS); Proliferation medium with foetal bovine serum (FBS); ${ }^{\star}$ Cells derived from patient 1

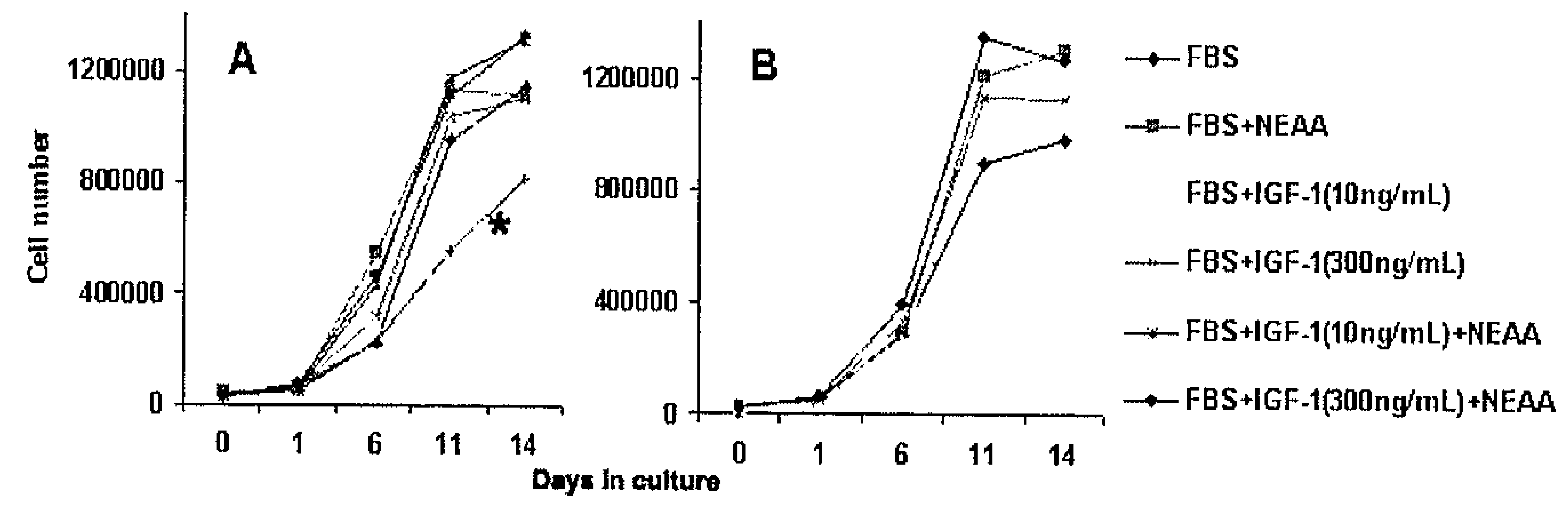

Figure 5. Number of periosteal-derived cells ${ }^{\star \star}$ after expansion in MEM (D)-valine supplemented with $10 \%$ FBS, IGF-1 (10 or $300 \mathrm{ng} / \mathrm{mL}$ ) and NEAA.

Proliferation medium with $10 \mathrm{ng} / \mathrm{mL}$ FGF-2; Proliferation medium with $100 \mathrm{ng} / \mathrm{Ml} \mathrm{FGF-2;}$ Control; ${ }^{\star \star}$ Cells derived from patient 2

Immunohistochemical staining of micromass cryosections was never positive for Collagen Type II, this in contrast to the Alcian blue staining which indicated cartilage like tissue. A zone of calcification was observed in a micromass stimulated with TGF- $\beta_{3}$, whereas no calcification was found when cultured with TGF- $\beta_{1}$ (Figure 2). In this particular case, the same sample showed a Collagen Type $\mathrm{X}$ expression of $6615 \mathrm{fg}$ per 200ng total RNA when cultured with $10 \mathrm{ng} / \mathrm{mL}$ TGF $-\beta_{1}$ and $12102 \mathrm{fg}$ Collagen Type $X$ per 200ng total RNA when cultured with $10 \mathrm{ng} / \mathrm{mL}$ TGF- $\beta_{3}$. Immunohistochemistry confirmed Collagen Type II mRNA expression in 2 alginate samples. These were cultured with 1 $\mathrm{ng} / \mathrm{mL}$ and $5 \mathrm{ng} / \mathrm{mL}$ TGF- $\beta_{3}$. All samples were positive for Thy-1. Figure 3 
shows representative micrographs of cytospins after immunocytochemical staining.

Collagen Type II mRNA was expressed in 25\% (5/20) of HELF cell cultures that were supplemented with growth factors. Only small amounts (less than 500 fg) were detected. No Collagen Type II mRNA expression was observed in HELF cell cultures without growth factors. Collagen Type I mRNA was detected in virtually every sample for both the control group as the cultures supplemented with growth factors. Collagen type X mRNA was observed in $50 \%(2 / 4)$ of control cultures compared to $90 \%(18 / 20)$ in cultures supplemented with growth factors.

FBS is essential for proliferation and FGF-2 enhances the proliferation rate. Cells did proliferate in MEM(D)-valine containing $10 \%$ FBS. When ITS was used as serum replacement cells did not expand (Figure 4). On day 8 the highest cell number was observed in culture medium containing $10 \% \mathrm{FBS}, 10 \mathrm{ng} / \mathrm{mL}$ FGF-2, $300 \mathrm{ng} / \mathrm{mL}$ IGF-1 and NEAA. During 1 week cell number increased 10 times. Highest cell numbers were reached when FGF-2 was added to the proliferation medium. Apparently FGF-2 played a key role in stimulating cell proliferation, whereas the effect of FGF-2 was enhanced by IGF-1 and NEAA. No additional effect on cell proliferation was observed when IGF-1 was used without FGF-2. The addition of NEAA or proline to FBS did not result in higher cell numbers compared to FBS without these supplements.

Cells did not proliferate in medium containing i) BSA with ITS, or ii) BSA with Ultroser ${ }^{\circledR} G$ instead of FBS. Even addition of growth factors did not result in cell proliferation (data not shown). Therefore we added 10\% FBS in following experiments. Again the addition of FGF-2 resulted in higher cell numbers compared to FGF-2 free medium (Figure 5). In medium containing 10 ng/mL FGF-2 (Figure 5A) highest cell numbers were observed when IGF-1 and NEAA were added. Proliferation did not enhance when the concentration of IGF-1 was increased from 10 to $300 \mathrm{ng} / \mathrm{mL}$. Similar results were observed when the concentration of FGF-2 was raised to $100 \mathrm{ng} / \mathrm{mL}$ (Figure 5B). However when $100 \mathrm{ng} / \mathrm{mL}$ FGF-2 was used highest cell numbers were observed after 11 days in culture, whereas maximal cell counts were observed after 14 days when only $10 \mathrm{ng} / \mathrm{mL}$ was added.

\section{DISCUSSION}

In the present study we optimized expansion and differentiation of aged human periosteal-derived cells. We showed that, after testing multiple culture media, growth factors and chondrogenesis assays, chondrogenic differentiation 
Chapter 4

56

remained variable. Most of the samples could be differentiated into a chondrogenic lineage.

In accordance to De Bari et al, we observed chondrogenic potential in aged human periosteum ${ }^{24}$. The percentage of samples showing chondrogenesis was variable. Whether this chondrogenic potential is dependent on donor age or cell culture passage number has been subject of investigation and remains controversial ${ }^{19,22,24}$. The percentage of progenitor cells is of importance. Since periosteum is a vascularized tissue with a fibrous layer and a cambium layer, a mixture of cells will be isolated and brought into culture. Several selection and culture procedures have been described ${ }^{15,19,23,24,35}$. However, we did not manage to detect cells or chondrogenic differentiation using most of these procedures ${ }^{15,19,24}$ (data not shown). Allowing cells to grow out of the tissue and expanding these cells in MEM(D)-valine was essential to detect chondrogenesis. Similar to other cell cultures, fibroblast overgrowth might have been inhibited, likely favoring expansion of periosteal progenitor cells $\mathrm{s}^{25-29}$.

Similar as described in rabbits, the cambium layer of the aged patient is, in contrast to the young patient, very thin ${ }^{22}$. The method of harvesting periosteum confirmed a cambium layer in the young patient. The surgical technique of harvesting periosteum is reported to be critical since the progenitor cells of the cambium layer are only lightly adhered to the periosteum and may be left at the bone surface ${ }^{36}$. It is known that the presence of this layer is essential for periosteal chondrogenesis in vitro ${ }^{16,17,20,21}$. The thin cambium cell layer in the aged patient makes a good control of osteochondrogenic progenitor cells after harvesting virtually impossible. This may explain why, in contrast to others, we found a variable periosteal chondrogenesis ${ }^{24}$. A specific marker for these periosteal progenitor cells is unknown ${ }^{35}$. Such a marker might enhance periosteal progenitor cell harvesting and culture methods by cell selection, thus making periosteum a more potential source for osteochondrogenic cells in tissue engineering techniques.

Growth factors played a pivotal role in the differentiation of periostealderived cells. In this experiment the differentiation toward a chondrocyte phenotype was achieved in representative high-density cell culture systems with addition of IGF- 1 and TGF- $\beta$ isomers in various concentrations. These growth factors are normally present in articular cartilage $e^{37,38}$ and are potentially important regulators of periosteal chondrogenesis ${ }^{17,18,24}$. Cells cultured with IGF-1 never expressed Type II collagen. This is in contrast to periosteal explant culture studies, wherein IGF-1 increased chondrogenesis when administered continuously throughout the culture period ${ }^{39,40}$. IGF-1 might only have a pivotal role in periosteal chondrogenesis when administered in combination with TGF- $\beta{ }^{39}$. Exogenous administered TGF- $\beta_{1}$ has a strong stimulatory, but dose-dependent, 
Variable chondrogenesis of aged human periosteal cells

effect on periosteal chondrogenesis ${ }^{21}$. It stimulates the proliferation of mesenchymal stem cells in the cambium layer, which is thought to be responsible for chondrogenic differentiation ${ }^{15,17,18,20}$. It has been described that TGF$\beta_{2}{ }^{41}$ and TGF- $\beta_{3}{ }^{42,43}$ also have a stimulatory effect on chondrogenesis from human bone marrow-derived mesenchymal stem cells, but were never used in periosteal differentiation studies. In this study, regardless of the TGF- $\beta$ isomer used, Type II collagen was expressed in most samples to which exogenous TGFâ was added. The highest Collagen Type II mRNA expression levels (>50 pg) were detected in alginate chondrogenesis assays using TGF- $\beta_{3}$ in DMEM/F12 with AA-2-P. A positive immunohistochemical staining for Collagen Type II was only detected using this assay. High percentages of Collagen Type I and X expressions were observed. The specific gene for hypertrophic cartilage, Collagen Type X, was prominent and was expressed in almost all study samples using RT-PCR techniques. Often this resulted in calcification of cultures. Although not exclusively proven, differentiation with TGF- $\beta_{3}$ seemed to induce more hypertrophy and calcification.

It is well-known that ascorbic acid enhances the redifferentiation of expanded chondrocytes. For chondrogenic periosteal differentiation, we observed an important role of ascorbic acid in chondrogenic differentiation of periosteal-derived cells. High concentrations of TGF- $\beta_{3}(10 \mathrm{ng} / \mathrm{ml})$ were necessary for positive Collagen Type II expression in alginate beads without supplementation of ascorbic acid. Without ascorbic acid lower concentrations of TGF- $\beta_{3}$ or concentrations of up to $300 \mathrm{ng} / \mathrm{mL}$ IGF-I did not result in collagen type II expressions. Addition of ascorbic acid to the differentiation medium resulted in high ( $>50 \mathrm{pg}$ ) Collagen Type II expressions with lower concentrations TGF- $\beta_{3}$. In micromasses cultured in ITS- and AA-2-Pcontaining medium, collagen type II mRNA was expressed in $59 \%$ of the growth factor-containing samples.

A low percentage of Collagen Type II positive, and a percentage of 50\% Collagen Type X positive samples in Human Embryonic Lung Fibroblasts indicate that potential chondrogenic assays were used. Furthermore, this finding may also question the use of HELF cells as control group. Since these cells have an embryonic origin, a higher progenitor cell yield might be present. On the other hand, this finding may indicate that, next to cells of the cambium layer, other cells can be differentiated. Therefore it remains speculative whether, under the appropriate conditions, other cells were also differentiated into the chondrogenic lineage.

Aged human periosteal-derived cells proliferated in MEM(D)-valine containing $10 \%$ FBS. However, proliferation was time consuming. Therefore several growth factors and serum-free conditions were tested in order to accel- 
Ch.ppter 4

58

erate the cell expansion in MEM(D)-valine. Serum-free culture conditions with either BSA, ITS or Ultroser ${ }^{\mathbb{B}} \mathrm{G}$ as serum replacement did not result in any proliferation at all. The addition of FGF-2, IGF-1 and NEAA increased the proliferation of periosteal-derived cells. FGF-2 played a key role in stimulating cell proliferation. It is known from literature that FGF-2 stimulates the mitotic activity of periosteum-derived cells ${ }^{20}$. The effect of FGF-2 was enhanced by IGF-1 and NEAA. In future experiments it has to be investigated whether the addition of the used growth factors has an effect on differentiation in a chondrogenic lineage.

In this study we show that, although variable, autologous periosteum of aged patients has chondrogenic potential. Favoring growth of progenitor cells seems essential and the chondrogenic potential of aged human periosteum can be increased by culturing these cells in MEM(D)-valine. Whereas for expansion of periosteal cells FBS was absolutely essential, differentiation could easily be achieved in serum-free conditions. Overall, heterogeneity of periosteal cell cultures and the lack to control the amount of progenitor cells may imply variable results when used as chondrogenic cell source, especially in the aged patient.

\section{Acknowledgements}

This study was supported by a grant from Senter (BTS 00021). The monoclonal antibody produced by T.F. Linsenmayer et al. (II-II6B3) and McDonald et al. was obtained from the Developmental Studies Hybridoma Bank, developed under the auspices of the NICHD, and maintained by the department of Biological Sciences of the University of Iowa (Iowa City, IA). The help of Martine Hulsbosch and Mireille Schrooten-van Helden was gratefully acknowledged.

\section{REFERENCES}

1. Gelber AC, Hochberg MC, Mead LA, Wang NY, Wigley FM, Klag MJ. Joint injury in young adults and risk for subsequent knee and hip osteoarthritis. Ann Intern Med 2000; 133(5):
$321-8$.

2. Mankin HJ. The reaction of articular cartilage to injury and osteoarthritis (second of two parts). N Engl J Med 1974; 291(25): 1335-40.

3. Pridie KH. A method of resurfacing osteoarthritic knee joints. Journal of Bone and Joint Surgery. British 1959; 41-B: 618-619.

4. Steadman JR, Rodkey WG, Rodrigo JJ. Microfracture: surgical technique and rehabilitation to treat chondral defects. Clin Orthop 2001; 391S: S362-9.

5. Bouwmeester P, Kuijer R, Terwindt-Rouwenhorst E, van der Linden T, Bulstra S Histological and biochemical evaluation of perichondrial transplants in human articular cartilage defects. J Orthop Res 1999; 17(6): 843-9. 
Variable chondrogenexis of aged human periosteal cells

6. Bouwmeester PS, Kuijer R, Homminga GN, Bulstra SK, Geesink RG. A retrospective analysis of two independent prospective cartilage repair studies: autogenous perichondrial grafting versus subchondral drilling 10 years post-surgery.J Orthop Res 2002;20(2):267-73.

7. Homminga GN, Bulstra SK, Bouwmeester PS, van der Linden AJ. Perichondral grafting for cartilage lesions of the knee. J Bone Joint Surg Br 1990; 72(6): 1003-7.

8. Hangody L, Kish G, Kárpáti Z, Szerb I, Udvarhelyi I. Arthroscopic autogenous osteochondral mosaicplasty for the treatment of femoral condylar articular defects. Knee Surg Sports Traumatology Arthroscopy 1997; 5:262-267.

9. Hangody L, Kish G, Kárpáti Z, Udvarhelyi I, Szigeti I, Bély M. Mosaicplasty for the treatment of articular cartilage defects: Application in clinical practice. Orthopedics 1998; 21(7): 751756.

10. Brittberg M, Lindahl A, Nilsson A, Ohlsson C, Isaksson O, Peterson L. Treatment of deep cartilage defects in the knee with autologous chondrocyte transplantation. $\mathrm{N}$ Engl J Med 1994; 331(14): 889-95.

11. Brittberg M, Peterson L, Sjogren-Jansson E, Tallheden T, Lindahl A. Articular cartilage engineering with autologous chondrocyte transplantation. A review of recent developments. J Bone Joint Surg Am 2003; 85-A Suppl 3: 109-15.

12. Niedermann B, Boe S, Lauritzen J, Rubak JM. Glued periosteal grafts in the knee. Acta Orthop Scand 1985; 56(6): 457-60.

13. O'Driscoll SW. Articular cartilage regeneration using periosteum. Clin Orthop Relat Res 1999(367 Suppl):S186-203.

14. O'Driscoll SW, Keeley FW, Salter RB. Durability of regenerated articular cartilage produced by free autogenous periosteal grafts in major full-thickness defects in joint surfaces under the influence of continuous passive motion. A follow-up report at one year. J Bone Joint Surg Am 1988; 70(4): 595-606.

15. Nakahara H, Bruder SP, Goldberg VM, Caplan AI. In vivo osteochondrogenic potential of cultured cells derived from the periosteum. Clin Orthop Relat Res 1990(259): 223-32.

16. Ito Y, Fitzsimmons JS, Sanyal A, Mello MA, Mukherjee N, O'Driscoll SW. Localization of chondrocyte precursors in periosteum. Osteoarthritis Cartilage 2001; 9(3):215-23.

17. O'Driscoll SW, Recklies AD, Poole AR. Chondrogenesis in periosteal explants. An organ culture model for in vitro study.J Bone Joint Surg Am 1994; 76(7): 1042-51.

18. Miura Y, Fitzsimmons JS, Commisso CN, Gallay SH, O'Driscoll SW. Enhancement of periosteal chondrogenesis in vitro. Dose-response for transforming growth factor-beta 1 (TGF-beta 1). Clin Orthop Relat Res 1994(301):271-80.

19. Nakahara H, Goldberg VM, Caplan AI. Culture-expanded human periosteal-derived cells exhibit osteochondral potential in vivo. J Orthop Res 1991; 9(4): 465-76.

20. Iwasaki $M$, Nakahara $H$, Nakata K, Nakase $T$, Kimura T, Ono K. Regulation of proliferation and osteochondrogenic differentiation of periosteum-derived cells by transforming growth factor-beta and basic fibroblast growth factor. J Bone Joint Surg Am 1995; 77(4): 543-54.

21. Iwasaki $M$, Nakata $K$, Nakahara $H$, Nakase $T$, Kimura $T$, Kimata $K$, et al. Transforming growth factor-beta 1 stimulates chondrogenesis and inhibits osteogenesis in high density culture of periosteum-derived cells. Endocrinology 1993;132(4): 1603-8.

22. O'Driscoll SWM, Saris DBF, Ito Y, Fitzimmons JS. The chondrogenic potential of periosteum decreases with age. Journal of Orthopaedic Research 2001; 19(1): 95-103.

23. Sakaguchi Y, Sekiya I, Yagishita K, Muneta T. Comparison of human stem cells derived from various mesenchymal tissues: superiority of synovium as a cell source. Arthritis Rheum 2005; 52(8): 2521-9. 
24. De Bari C, Dell'Accio F, Luyten FP. Human periosteum-derived cells maintain phenotypic stability and chondrogenic potential throughout expansion regardless of donor age. Arthritis Rheum 2001; 44(1): 85-95.

25. Gilbert S, Migeon B. D-valine as a selective agent for normal human and rodent epithelial cells in culture. Cell 1975; 5: 11-17.

26. Armati PJ, Constable AL, Llewellyn F. A new medium for in vitro peripheral nervous tissue myelination without the use of antimitotics. J Neurosci Methods 1990; 33(2-3): 149-55.

27. Frauli $M, L$ udwig $H$. Inhibition of fibroblast proliferation in a culture of human endometrial stromal cells using a medium containing D-valine. Arch Gynecol Obstet 1987;241(2):87-96.

28. Hongpaisan J. Inhibition of proliferation of contaminating fibroblasts by $D$-valine in cultures of smooth muscle cells from human myometrium. Cell Biol Int 2000;24(1): 1-7.

29. Piquette GN, Timms BG. Isolation and characterization of rabbit ovarian surface epithelium, granulosa cells, and peritoneal mesothelium in primary culture. In Vitro Cell Dev Biol 1990; 26(5): 471-81.

30. Fitzsimmons JS, Sanyal A, Gonzalez C, Fukumoto T, Clemens VR, O'Driscoll SW, et al. Serum-free media for periosteal chondrogenesis in vitro.J Orthop Res 2004;22(4):716-25.

31. Vukicevic S, Luyten FP, Reddi AH. Stimulation of the expression of osteogenic and chondrogenic phenotypes in vitro by osteogenin. Proc Natl Acad Sci U S A 1989; 86(22): 8793-7.

32. Kuijer R, Surtel DA, Van Der Linden AJ, Bulstra SK, Passier RC. A novel method to examine the phenotype of chondrocytes. J Mater Sci Mater Med 1998; 9(12): 749-54.

33. Dharmavaram RM, Baldwin CT, Reginato AM, Jimenez SA. Amplification of cDNAs for human cartilage-specific types II, IX and XI collagens from chondrocytes and Epstein-Barr virus-transformed lymphocytes. Matrix 1993; 13(2): 125-33.

34. Reichenberger E, Beier F, LuValle P, Olsen BR, von der Mark K, Bertling WM. Genomic organization and full-length cDNA sequence of human collagen X. FEBS Lett 1992;311(3): 305-10.

35. Lim SM, Choi YS, Shin HC, Lee CW, Kim DI. Isolation of human periosteum-derived progenitor cells using immunophenotypes for chondrogenesis. Biotechnol Lett 2005; 27(9): $607-11$.

36. Brownlow HC, Reed A, Joyner C, Simpson AH. Anatomical effects of periosteal elevation.J Orthop Res 2000; 18(3): 500-2.

37. Fukumura $K$, Matsunaga $S$, Yamamoto $T$, Nagamine $T$, Ishidou $Y$, Sakou $T$. Immunolocalization of transforming growth factor-beta s and type I and type II receptors in rat articular cartilage. Anticancer Res 1998; 18(6A): 4189-93.

38. Kato Y, Nomura Y, Tsuji M, Kinoshita M, Ohmae H, Suzuki F. Somatomedin-like peptide(s) isolated from fetal bovine cartilage (cartilage-derived factor): isolation and some properties. Proc Natl Acad Sci U S A 1981; 78(11):6831-5.

39. Fukumoto T, Sperling JW, Sanyal A, Fitzsimmons JS, Reinholz GG, Conover CA, et al. Combined effects of insulin-like growth factor-1 and transforming growth factor-beta 1 on periosteal mesenchymal cells during chondrogenesis in vitro. Osteoarthritis Cartilage 2003; $11(1): 55-64$.

40. Mierisch CM, Anderson PC, Balian G, Diduch DR. Treatment with insulin-like growth factor-1 increases chondrogenesis by periosteum in vitro. Connect Tissue Res 2002; 43(4): 559-68.

41. Wang WG, Lou SQ, Ju XD, Xia K, Xia JH. In vitro chondrogenesis of human bone marrowderived mesenchymal progenitor cells in monolayer culture: activation by transfection with TGF-beta2. Tissue Cell 2003; 35(1): 69-77. 
Variable chondrogenesis of aged human periosteal cells

42. Huang CY, Reuben PM, D'Ippolito G, Schiller PC, Cheung HS. Chondrogenesis of human bone marrow-derived mesenchymal stem cells in agarose culture. Anat Rec A Discov Mol Cell Evol Biol 2004; 278(1): 428-36.

43. Indrawattana $\mathrm{N}$, Chen $\mathrm{G}$, Tadokoro $\mathrm{M}$, Shann LH, Ohgushi $\mathrm{H}$, Tateishi $\mathrm{T}$, et al. Growth factor combination for chondrogenic induction from human mesenchymal stem cell. Biochem Biophys Res Commun 2004; 320(3): 914-9. 


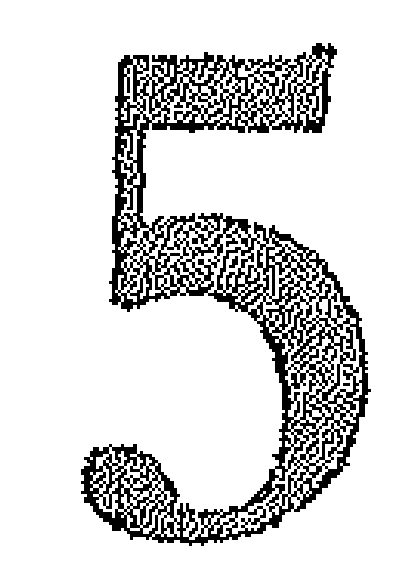

Differential cell viability of chondrocytes and progenitor cells in tissue engineered constructs following implantation into osteochondral defects

Emans, P.J., Pieper, J., Hulsbosch, M., Koenders, M., Kreijveld, E., Surtel, D.A.M., van Blitterswijk C.A., Bulstra, S.K., Kuijer, R, Riesle J.

Tissue Eng. 2006 Jun; 12(6):1699-709 


\begin{abstract}
Animal studies in cartilage tissue engineering usually include the transfer of cultured cells into chondral or osteochondral defects. Immediately at implantation, the cells will be exposed to a dramatically changed environment. The aim of this study was to determine the viability of two cell types currently considered for cellular therapies of cartilage defects -chondtocytes and progenitor cells- shortly after exposure to a osteochondral defect in rabbit knees.

To that end, autogenic chondrocytes and periosteal cells were labeled with CM-Dil fluorochrome, seeded or cultured in PEGT/PBT scaffolds for periods up to 2 weeks, transferred into osteochondral defects, harvested 5 days postimplantation, and analyzed for cell viability. In order to further elucidate factors effecting cell viability within our model system, we investigated the effect of serum, 2) extracellular matix surrounding implanted cells, 3) scaffold interconnectivity, and 4) hyaluronan, as a known cell protectant. Controls included scaffolds with devitalized cells and scaffolds analyzed at implantation.

We found that viability of periosteum cells (14\%) but not of chondrocytes (65-95\%) was significantly decreased after implantation. The addition of hyaluronan increased periosteum cell viability to $44 \%(\mathrm{p}<0.05)$. Surprisingly, cell viability in less interconnected compression-molded scaffolds was higher compared to that of fully interconnected scaffolds produced by rapid prototyping. All other factors tested did not affect viability significantly,

Our data suggest chondrocytes as a suitable cell source for cartilage repair in line with clinical data on several chondrocytes-based therapies. Although we did not test progenitor cells other the periosteum cells, tissue engineering approaches using such cell types should take cell viability aspects into consideration.
\end{abstract}

\title{
INTRODUCTION
}

The possibilities for treatment of cartilage defects have improved considerably due to progress in the field of Tissue Engineering (TE). Recently studied and applied methods for cartilage repair, such as Autogenic Perichondrium transplantation ${ }^{1,2}$, Autogenic Periosteum Transplantation ${ }^{3}$, Autogenic Chondrocyte Implantation (ACI $)^{4}$ and Mosaic Plasty ${ }^{5,6}$, are all examples of TE according to the definition of Langer? 
At present substantial research focuses on the transplantation of cultured cells with chondrogenic potential seeded into biodegradable scaffolds. Such scaffold facilitate cellular transfer to and retention within the defect and, if appropriately selected, may provide mechanical functionality". A major question in tissue engineering is the selection of a viable cell source. Both chondrocytes and progenitor cells are currently considered for cellular therapies of cartilage defects. Progenitor cells from bone marrow have been widely used. However, animal-derived bone marrow cells, in particular from rabbit origin, have shown a highly variable chondrogenic potential'. Previously, it was established that periosteal cells are a potential source of chondro-progenitor cells ${ }^{10,11}$.

Our aim was to test the hypothesis that progenitor cells and chondrocytes react differentially upon transfer into osteochondral joint defects. This hypothesis is based on the differential in vivo histories of these cell types: progenitor cells are in close vicinity to vasculature and thus to sufficient nutrient supply including oxygen, but chondrocytes are not ${ }^{12,13}$

The effectiveness of any cellular repair approach will depend on the retention of cell viability early after implantation ${ }^{14,15}$. Surprisingly, little is known of the survival of transplanted cells ${ }^{16}$. To our knowledge we report here for the first time a detailed analysis of cell viability in the initial osteochondral repair phase.

At implantation, cell environment changes considerably. Cell culture conditions have been optimized for either proliferation or (re)differentiation of cells. Once transplanted in an osteochondral woundbed, cells are exposed to the hostile conditions of the primary wound healing reaction, including polymorphonuclear cells, catabolic enzymes and deleterious cytokines (TNF $\alpha$, IL-1). Other potential harmful factors are mechanical forces and changes in the supply of nutrients and oxygen.

Factors that may affect cell viability upon transplantation include: 1) immunological, due to traces of foreign body proteins from culture media (i.e. fetal bovine serum [FBS]), 2) the presence of extracellular matrix, which may protect the cells and keep them well differentiated, and 3) interconnectivity of pores within the scaffold, which will determine the nutrient and oxygen supply.

In this study we addressed these factors, by 1) comparing chondrocytes with progenitor cells from periosteun, 2) comparing chondrocytes and periosteal cells cultured in media containing FBS with cells cultured in media containing autogenic serum (AS), 3) comparing chondrocytes that were seeded and implanted with chondrocytes that were seeded, cultured for 2 weeks, and implanted, and 4) comparing chondrocytes seeded on scaffolds produced by compression molding and salt leaching (CM-scaffold) with chondrocytes seeded on scaffolds with increased interconnectivity produced by rapid prototyping (RP scaffold). In addition, we tested whether hyaluronan could be 
Chapter 5

66

used as a cell-protective agent by injecting it intra-articularly after closure of the joint ${ }^{13,17-22}$.

To distinguish transplanted cells from endogenous ones, the cells to be transplanted were labeled with the fluorochrome chloromethyl-benzamidodialkylcarbocyanine (CM-Dil). This fluorescent marker becomes intercalated within the cell membrane lipid bilayer and is useful for tracing cells in cell survival studies ${ }^{16,23,24}$. The dye has been demonstrated not to effect cell metabolism or viability for a number of different cell types ${ }^{16,25-27}$. Possible transfer of the dye to endogenous cells ${ }^{16}$ was tested in vitro by a filter assay and in vivo after implantation of cell-scaffold constructs in nude mice.

To assess whether transplanted cells survived transplantation, Sytox Green was applied immediately after explantation to stain dead cells ${ }^{28}$. Sytox Green has been used in several cell viability studies ${ }^{29,30}$ and can be combined with 4,6diaminodino-2-phenidole (DAPI) to detect viable and non viable cells.

\section{MATERIAL AND METHODS}

\section{Scaffolds}

PEGT/PBT (PolyActive ${ }^{\mathrm{TM}}$ ) scaffolds from IsoTis OrthoBiologics (Bilthoven, The Netherlands) were used. PEGT/PBT is an elastomeric, segmented multiblock co-polymer comprised of poly(ethyleneglycolteraphthalate) and poly(butylene teraphthalate) ${ }^{8}$. The molecular weight of the PEG in the polymer used for this study was $300 \mathrm{D}$, and the weight ratio PEGT/PBT was 55:45. This co-polymer has been shown to be biocompatible and biodegradable ${ }^{31,32}$. Scaffolds were made by the compression molding and salt leaching method (CM scaffold) or by rapid prototyping (RP scaffold) ${ }^{8}$. Three-dimensional microcomputed tomography $(\mu \mathrm{CT})$ was used to characterize scaffold architecture $^{33}$. The scaffolds had a comparable porosity of approximately $80 \%$. The average pore sizes for the CM and RP scaffolds were $182 \mu \mathrm{m}$ and $525 \mu \mathrm{m}$, respectively. The accessible pore volume (measure for interconnectivity) at a pore size of $200 \mu \mathrm{m}$ was $20 \%$ for the CM scaffold. By contrast, the RP scaffolds had an accessible pore volume of $98 \%$. Scaffolds were sterilized by $\gamma$-irradiation at $25 \mathrm{kGy}$.

\section{Isolation of autogenic blood, cartilage and periosteum}

European and Dutch regulations on animal experimentation were strictly followed throughout the study. The study was approved by the local committee for animal experiments. Eighteen adolescent female New Zealand white rabbits (age 6 months, weight $3-4.5 \mathrm{~kg}$ ) were used. Fourteen days prior to the first operation, 10 days after the first operation and 10 days prior to the second oper- 
ation $15 \mathrm{~mL}$ of arterial blood was collected from the ear. Autogenic serum was isolated and complement-inactivated by heating at $56^{\circ} \mathrm{C}$ for 50 minutes.

Surgical procedures were performed using sterile techniques under general anesthesia. Anesthetic induction was obtained with $35 \mathrm{mg} / \mathrm{kg}$ Ketamine hydrochloride and $5 \mathrm{mg} / \mathrm{kg}$ Xylazine hydrochloride i.m. and maintained by a mixture of $2 \%$ halothane and oxygen/nitrous oxide. Preoperatively all rabbits received antibiotics $(10 \mathrm{mg} / \mathrm{kg}$ ceftiofur sodium, Pharmacia \& Upjohn, Woerden, The Netherlands). Postoperative analgesia was provided with $0.05 \mathrm{mg} / \mathrm{kg}$ buprenorfine i.m.

In both knees an arthrotomy was performed: the patella was luxated laterally and the joint surfaces were exposed. A cartilage-only defect with a diameter of 4 $\mathrm{mm}$ was created with a sharp dermal punch on the medial and lateral femoral condyles of both knees. The removed cartilage was collected. Then cartilage from the patellar groove was dissected sparing the rims of the groove, and harvested as well. After closure of the joint a periosteal flap of about $7 \times 15 \mathrm{~mm}$ was harvested from the proximal medial tibia of both legs. The wounds were closed in layers using resorbable sutures.

\section{Cell isolation}

Articular cartilage was transported to IsoTis S.A. in transport medium: Dulbecco's modified Eagles Medium (DMEM) containing HEPES as buffer, $0.2 \mathrm{mM}$ ascorbic acid-2-phosphate, $0.4 \mathrm{mM}$ L-proline, $0.1 \mathrm{mM}$ non-essential amino acids, 100 units $/ \mathrm{mL}$ penicillin and $100 \mu \mathrm{g} / \mathrm{mL}$ streptomycin. At IsoTis Orthobiologics, half of the samples were digested overnight with $300 \mathrm{U} / \mathrm{mL}$ collagenase type II in HEPES-buffered DMEM for isolation of chondrocytes, which were expanded for $2-3$ passages (18 days), then isolated, labeled with CMdiI and seeded on to scaffolds. These cells-scaffold constructs were subsequently cultured for two weeks (cultured groups). The other half of the samples were left in transport medium in a $\mathrm{CO}_{2}$-incubator for 2 weeks and the medium was refreshed three times a week. Then the chondrocytes were isolated, expanded for 2-3 passages (18 days), labeled, and, 3 days prior to implantation seeded on to scaffolds (seeded groups).

Expansion of chondrocytes was performed in monolayer cultures in culture medium: DMEM supplemented with $0.2 \mathrm{mM}$ ascorbic acid-2-phosphate, 0.4 $\mathrm{mM}$ L-proline, $0.1 \mathrm{mM}$ nonessential amino acids, $100 \mathrm{U} / \mathrm{mL}$ penicillin, 100 $\mu \mathrm{g} / \mathrm{mL}$ streptomycin and either $10 \%$ AS or $10 \%$ FBS, in 2-3 passages for 18 days.

Isolation of periosteum cells was performed in the research laboratory of the Department of Orthopedics in Maastricht. Periosteum was incubated with 300 $\mathrm{U} / \mathrm{mL}$ collagenase type II (Invitrogen, Breda, The Netherlands) in DMEMHepes medium supplemented with $100 \mathrm{U} / \mathrm{ml}$ penicillin and $100 \mu \mathrm{g} / \mathrm{ml}$ strep- 
tomycin for $3 \mathrm{~h}$ at $37^{\circ} \mathrm{C}$. Subsequently cells were allowed to grow in culture flasks in DMEM/Ham's F12 (1:1) medium (Invitrogen) supplemented with $10 \%$ FBS, $0,1 \mathrm{mM}$ non-essential amino acids, $100 \mathrm{U} / \mathrm{mL}$ penicillin and 100 $\mu \mathrm{g} / \mathrm{mL}$ streptomycin. After 1 week, this was changed to MEM-D-valine medium supplemented with non-essential amino acids, 10\% FBS and antibiotics to avoid fibroblast overgrowth ${ }^{34}$. Due to the limited amount of AS and the poor growth of periosteal cells in medium with AS, we decided to expand periosteal cells of the AS group in medium with FBS and to use AS medium only in the final passage and the seeding procedure.

\section{Cell labeling}

Before labeling, the cells were counted in a hemocytometer. Chondrocytes and periosteal cells were labeled in a solution of $40 \mu \mathrm{M}$ CM-Dil in HBSS, according to the technique described by Kruyt et al. ${ }^{16}$.

Sytox Green labeling was performed by incubating cells with $100 \mathrm{nM}$ Sytox Green (Molecular Probes, Leiden, The Netherlands) in PBS for 20 minutes at room temperature.

CM-DiI and Sytox Green labeled cells were analyzed by fluorescence microscopy (E800, Nikon, Tokyo, Japan). The viable and dead cells were expressed as a percentage of the total amount of labeled cells.

\section{Cell seeding and culturing on scaffolds}

CM-Dil-labeled chondrocytes or periosteal cells were seeded on PEGT/PBT scaffolds using a dynamic cell seeding protocol: $1 \times 10^{6}$ cells in $40 \mu \mathrm{L}$ culture medium were applied on top of a pre-wetted and dry-blotted scaffold in an Eppendorf vial. Scaffolds with cells were left for $6 \mathrm{~h}$ to allow the cells to attach, then $1 \mathrm{~mL}$ culture medium was added and the constructs were placed on a roller-bar or rotating incubator for 3 days. For the cultured-group, after these 3 days the chondrocytes-scaffold constructs were placed into 24-well plates and cultured for 2 weeks in culture medium.

\section{Implantations}

Five weeks after the first operation the animals were operated again. All cellscaffold constructs to be implanted and controls were washed five times for 5 min with a sterile $0.9 \% \mathrm{NaCl}$ solution at room temperature.

The knee was opened using a medial parapatellar incision. Holes of $4 \mathrm{~mm}$ diameter $\times 4 \mathrm{~mm}$ deep were created in the central, weight-bearing portion of the medial and lateral condyles of both knees using a low-speed drill (150 rpm) and constant cooling. The defects were irrigated and autogenic cell-scaffold constructs were press fit into the defects. Twelve groups were distinguished (Table 1). Implants were distributed in such a manner that duplicate observa- 
Viability of chondrocytes and progenitor cells in TE constructs

Table 1: Groups in the implantation study

\begin{tabular}{|c|c|c|c|c|c|c|c|c|}
\hline \multirow{2}{*}{$\begin{array}{l}\text { Group } \\
1 \mathrm{a}\end{array}$} & \multirow{2}{*}{$\begin{array}{l}\text { Cell type } \\
\text { No cells }\end{array}$} & \multicolumn{2}{|c|}{ Scaffold Serum } & \multirow{2}{*}{$\begin{array}{l}\mathrm{S}(\text { eeded) } \\
\text { or } \\
\text { C(ultured) }\end{array}$} & \multirow[t]{2}{*}{ HYA } & \multirow{2}{*}{$\begin{array}{c}\mathrm{T}=0 \\
\mathrm{~N}\end{array}$} & \multirow{2}{*}{$\begin{array}{c}T=5 \\
N \\
4\end{array}$} & \multirow{2}{*}{$\begin{array}{l}\text { Nomen- } \\
\text { clature }\end{array}$} \\
\hline & & $\mathrm{CM}$ & & & & & & \\
\hline $1 b$ & No cells & $\mathrm{RP}$ & & & & & 4 & \\
\hline 2 & Chondrocytes & $\mathrm{CM}$ & FBS & $S$ & & 6 & 6 & CCFS \\
\hline 3 & Chondrocytes & $\mathrm{CM}$ & AS & S & & 5 & 5 & CCAS \\
\hline 4 & Chondrocytes & $\mathrm{CM}$ & FBS & C & & & 5 & $\mathrm{CCFC}$ \\
\hline 5 & Chondrocytes & $\mathrm{CM}$ & AS & C & & & 6 & $\mathrm{CCAC}$ \\
\hline 6 & Chondrocytes & $\mathrm{CM}$ & AS & $\mathrm{C}$ & HYA & 5 & 6 & $\mathrm{CCAC}+\mathrm{H}$ \\
\hline 7 & Chondrocytes & $\mathrm{RP}$ & FBS & $S$ & & 3 & 6 & CRFS \\
\hline 8 & Chondrocytes & $\mathrm{RP}$ & FBS & $\mathrm{C}$ & & & 6 & CRFC \\
\hline 9 & Periosteal cells & $\mathrm{CM}$ & FBS & $S$ & & & 4 & PCFS \\
\hline 10 & Periosteal cells & $\mathrm{CM}$ & AS & S & & 3 & 5 & PCAS \\
\hline 11 & Periosteal cells & $\mathrm{CM}$ & AS & S & HYA & & 5 & $\mathrm{PCAS}+\mathrm{H}$ \\
\hline 12 & Chondrocytes (dead) & $\mathrm{CM}$ & FBS & $S$ & & & 4 & \\
\hline
\end{tabular}

Serum, the serum with which the culture medium was supplemented for $10 \%$; FBS, fetal bovine serum; AS, autogenous serum; CM, compression molded, salt leached PEGT/PBT 300 55/45 scaffold; P, PEGT/PBT 300 55/45 scaffold produced by rapid prototyping; seeded (S), cells seeded on to the scaffolds by a dynamic procedure for 3 days prior to implantation; cultured $(C)$, after seeding the scaffolds and cells were kept in culture for 2 weeks before implantation; HYA, $5 \mathrm{~mL}$ of $10 \mathrm{mg} / \mathrm{mL}$ hyaluronan i.a. immediately postoperatively.

tions were avoided as much as possible and that the implants could not influence each other. Animals in two groups received an injection of $1 \mathrm{ml}(10 \mathrm{mg} / \mathrm{ml})$ hyaluronan (HYA) (Ostenil, Chemedica, Munich, Germany) intra-articularly after closure of the wound.

\section{Explantation}

Five days after implantation, the animals were euthanized with an overdose of pentobarbital. The cell-scaffold constructs were isolated from the osteochondral defects and cut in two equal parts; one part was prepared for GMA sectioning and histological examination, the other part was stained with Sytox Green as described above, embedded in OCT-compound and immediately frozen. Forty $\mu \mathrm{m}$ cryosections were cut, fixed in acetone for 10 minutes at $-20^{\circ} \mathrm{C}$, stained with DAPI (Sigma), mounted with an anti-fading reagent (Molecular Probes, Leiden, The Netherlands) and analyzed using fluorescence microscopy. At a magnification of $400 \mathrm{x}$, five areas of each section were photographed using three filters; the Texas Red filter (excitation, 540-580nm; dichroic mirror 595) for CM-DiI label, the DAPI filter (excitation, 340-380 nm; dichroic mirror $400 \mathrm{~nm}$ ); and the 
Chapers

701

FITC filter (excitation 465-495 nm; dichroic mirror 505) for Sytox Green. The 3 photographs of each area were combined using Photoshop ${ }^{\text {TM }} 6.0$ software (Adobe) and analyzed. Analysis was done by two independent observers, who were blinded for the different groups. CM-DiI labeled cells without a nucleus (Figure 1A) or with a green (Sytox Green) nucleus (Figure 1A) were regarded to be dead and CM-DiI-labeled cells showing a blue (DAPI) nucleus (Figure 1A, 13) were regarded viable. The data of the two observers were combined and averaged.

\section{Cell viability at implantation}

In order to examine cell viability and seeding quality at implantation, control scaffolds with CMDil-labeled cells were incubated with Sytox green at the day of the implantation, fixed, embedded and analyzed as described above.

\section{Statistics}

The One way ANOVA and the post-hoc Newman Keuls test were used for statistical analysis. The significance level was $\mathrm{p}<0.05$.

\section{Validation of methodology}

The optimal labeling protocol was established by labeling of chondrocytes with $5,10,20$, or $40 \mu \mathrm{M}$ CM-DiI in Hank's balanced salt solution (HBSS) (Molecular Probes, Leiden, The Netherlands) according to the technique described by Kruyt et al. ${ }^{16}$.

To validate the Sytox Green staining as a means to assess cell death, vital and devitalized, Sytox Green labeled cells were counted and compared to similar samples analyzed by the trypan blue exclusion assay.

\section{Transfer of label in vitro and in vivo}

Rabbit articular chondrocytes were cultured in a 6 -well plate and a $0.4 \mu \mathrm{m}$ filter (transwell PC, Costar) was placed above the cells. Permeability of the filter for CM-DiI was tested by applying a $40 \mu \mathrm{M} \mathrm{CM}$-DiI solution on top of the filter. The same model was used to monitor transfer of label from labeled to unlabeled chondrocytes. Vital or devitalized CMdiI-labeled rabbit articular chondrocytes were placed on top of the filter. After time periods up to 10 days, the cells at the bottom of the well were examined for transfer of CM-Dil using fluorescence microscopy.

For the in vivo experiment, CM-DiI-labeled chondrocytes were seeded on $\mathrm{CM}$ scaffolds. Cells in some of the constructs were devitalized by two cycles of freezing and thawing. The constructs were implanted subcutaneously in nude mice. After 5 and 10 days, the mice were sacrificed and the scaffolds were harvested with the surrounding fibrous tissue. To assess in vivo label transfer, 
consecutive sections were examined using light (thionine staining) and fluorescence microscopy, respectively.

The ability of Sytox Green to penetrate tissue

The ability of the Sytox Green dye to penetrate $4 \mathrm{~mm}$ diameter $\mathrm{x} 4 \mathrm{~mm}$ scaffolds in which tissue has been grown was evaluated by incubating $4 \mathrm{~mm}$ diameter $\times 4 \mathrm{~mm}$ devitalized pieces of bovine articular cartilage with the Sytox Green solution according to the protocol described. Frozen sections were examined using fluorescence microscopy.

\section{RESULTS}

\section{CM-DiI labelling}

For both cell types, the optimal CM-Dil concentration appeared to be $40 \mu \mathrm{M}$. The amount of labeled cells increased with the concentration of CM-DiI. At 5 $\mu \mathrm{M}$ CM-Dil, only $2.5 \%$ of the cells were labeled. Using a concentration of 40 $\mu \mathrm{M}$ CM-Dil, $68 \%$ of the periosteal cells and $43 \%$ of the chondrocytes were labeled. At this concentration, the CM-Dil label slightly reduced viability for both cells types; before labeling $91 \%$ of the cells were viable, after the label procedure about $76 \%$ of the cells were viable (both cell types). The viability did not decrease further in time during the period of evaluation. At higher concentrations, the label caused a reduction of viability below $50 \%$.

\section{Sytox Green labeling of dead cells}

When Sytox Green labeling was compared with trypan blue exclusion to assess the viability of cultured cells, the viability rates were the same (data not shown). The dye appeared to be able to diffuse to the center of $4 \times 4 \mathrm{~mm}$ devitalized cartilage biopsies (data not shown). We concluded that Sytox Green stained devitalized cells only and was able to penetrate cartilaginous tissues.

\section{Testing and transfer of the label in vitro}

The CM-DiI label freely diffused through the $0.4 \mu \mathrm{m}$ filters and did label the underlying chondrocytes. When labeled cells were placed on top of the filter, no evidence for transfer of label was found within 6 days. First after 7 days, transfer of label from devitalized chondrocytes to the living chondrocytes was observed. Transfer of label from living chondrocytes to the underlying chondrocytes was first observed after 11 days.

The label did not have an effect on the seeding of the cells in the scaffold; cells were distributed homogenous throughout the scaffold (data not shown).

The Fluorescence of both CM-DiI and Sytox Green was not affected by the processing of labeled cells/tissue for cryosectioning. Embedding in GMA did 
not affect the CM-Dil fluorescence; however the fluorescence of Sytox Green could no longer be detected.

\section{In vivo label transfer in a nude mice model}

The implanted chondrocyte clusters could easily be distinguished from infiltrating mouse cells (Fig. 2A and B). No transfer of label was detected during the first five days after implantation of either vital or devitalized implants (Fig. 2A). At day 7, labeled mouse cells could be detected next to devitalized implants (Fig. 2B). Transfer of label from vital implants was not detected during the 10 days of this experiment.

\section{Cell viability in PEGT/PBT scaffolds in osteochondral defects}

The auto-fluorescence of the scaffold did not substantially affect the evaluation. In devitalized implants, a survival rate of $3.9 \pm 3.1 \%$ was found. At $t=0$ the viability of cells in all chondrocyte groups was approximately $90 \%$ independent of pre-culturing or scaffold type. The viability of the periosteal cells cultured in media with AS was $79 \%$ at the time of implantation.

At explantation ( $t=5$ days) all groups with chondrocytes with the exception of one (with added hyaluronan), showed no significant decrease in cell viability compared to $\mathrm{t}=0$ (Fig. 3A). However, a significant decrease in cell viability was observed for the periosteal cells, $78.7 \pm 8.8$ at $\mathrm{t}=0$ and $19.8 \pm 11.9 \%$ at $\mathrm{t}=5(\mathrm{p}<$ 0.001).

When both cell types were expanded in media with AS, seeded on to CM scaffolds, and implanted (Fig. 3B), $95.3 \pm 2.2 \%$ of the chondrocytes were viable after 5 days, but only $19.8 \pm 11.9 \%$ of the periosteal cells were $(p<0.0001)$.

Chondrocytes expanded in medium supplemented with AS showed a slightly but not significantly, increased viability compared to those expanded in medium containing FBS. In contrast, periosteal cells tend to show increased viability after being expanded in culture medium with FBS compared to those being expanded in culture medium with AS (29.9 \pm 19.9 and $19.8 \pm 11.9 \%$, respectively, not significant) (Fig. 3C).

There were no differences in survival of chondrocytes between any groups when chondrocytes were implanted after being seeded or implanted after an additional culture period of 2 weeks (Fig. 3D).

The CM scaffolds yielded more viable chondrocytes than did RP scaffolds: for seeded cells $84.6 \pm 10.2 \%$ and $74.2 \pm 16.4 \%$, not significant: for cultured cells $83.3 \pm 10 \%$ and $65.1 \pm 12 \%$, respectively, not significant (Fig. $3 \mathrm{E}$ ).

When HYA was administered, the number of periosteal cells surviving the implantation increased $(44.2 \pm 16.6$ compared to $19.8 \pm 11.9 \%(\mathrm{p}<0.05)$ (Fig. $3 F)$. This effect from HYA was not observed for chondrocytes. 
Viability of chondrocytes and progenitor cells in TE constructs

\begin{abstract}
Histology of osteochondral defects
In general, the explanted scaffolds contained fibrin and areas with apoptotic cells as can be expected during the wound healing process (Fig. 4). Scaffolds with seeded chondrocytes from groups that were supplemented with hyaluronan contained more clusters of cells with a cartilage-like appearance compared to those to which no HYA was added (Fig. 4A).
\end{abstract}

\title{
DISCUSSION
}

In this study the viability of autogenic chondrocytes and periosteum-derived progenitor cells in tissue engineered cartilage constructs was evaluated following implantation into osteochondral defects in rabbit knees for 5 days. This shortterm follow-up was selected to study cell viability upon transfer from cell culture conditions to an osteochondral defect wound bed. Only viable cells can be expected to contribute to tissue repair.

In general, a major fraction, if not all, of autogenic chondrocytes survived the transfer into a osteochondral wound bed. In contrast, only a minor fraction of progenitor cells retained their viability. Our findings indicate that cell survival in tissue-engineered constructs is mainly influenced by cell type. In contrast to periosteal cells, articular chondrocytes originate from a nonvascular tissue dominated by mechanical forces and low oxygen concentrations. Accordingly, chondrocytes may be less affected by deprivation of oxygen and nutrients or the presence of inflammatory mediators, even after being expanded in monolayer culture, than are progenitor cells from periosteum.

Periosteal cells were not stimulated to differentiate into the chondrogenic lineage before implantation. Differentiated periosteal cells may show an improved viability compared to undifferentiated cells. In a recent study, Ball et al. demonstrated increased viability of differentiated, allogeneic perichondrium cells upon implantation compared to nondifferentiated ones ${ }^{35}$.

Periosteum consists of two layers. The major cell types are fibroblasts from the fibrous layer and progenitor cells from the cambium layer. Next to these, the tissue also contains small amounts of vascular smooth muscle cells and endothelial cells. The cell isolate is therefore heterogeneous. By using culture medium in which L-valine is substituted with D-valine, we attempted to inhibit fibroblast growth. However, our data indicate that we were unable to fully eliminate these cells (unpublished data). We therefore cannot exclude, that viability data for the periosteum group reflect in fact the selective survival of a subpopulation of a heterogenous cell isolate. In addition, it remains to be elucidated, whether the 


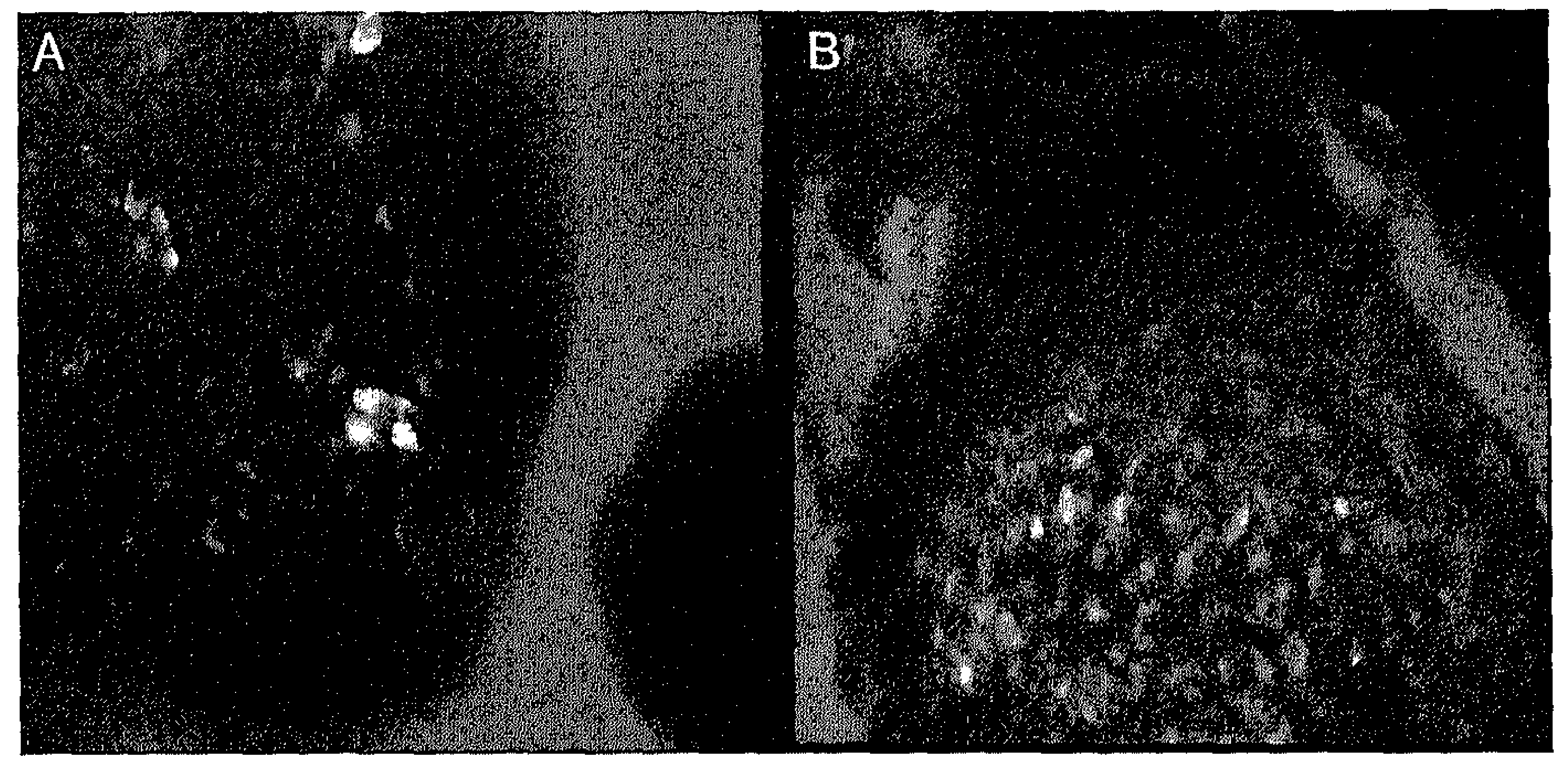

Figure 1. Fluorescence micrographs of CM-DiI (red) stained chondrocytes with a blue (DAPI) nucleus are considered viable. (A) The green nuclei are of nonviable CM-DiI labeled (red cell, right upper corner) and non-CM-Dil labeled cells. CM-Dil labeled cells without blue nuclei are also regarded non-viable, (B) A CM-Dil labeled chondrocyte cluster. Notice chondrocytes with and without blue nucleus. See page 146 for colour figure.

low viability of periosteal cells upon implantation reported herein also applies for progenitor cells from other origins, such as bone marrow or adipose tissue.

There is little evidence in the literature about the fate of implanted cells in tissue- engineered constructs. To our knowledge, we report here for the first time a detailed analysis on cell viability in the initial osteochondral repair phase. Quintavalla et al. studied fluorescently labeled mesenchymal stem cells after implantation in osteochondral defects in goats. Although some of the labeled cells were present 2 weeks postimplantation, cell viability was not assessed ${ }^{36}$. Mierisch et al. and Dell'Accio et al. studied the contribution of transplanted chondrocytes in a rabbit and a goat model, respectively, of autologous chondrocyte transplantation ${ }^{37,38}$. Mierisch et al. found the labeled cells were not incorporated in the repair tissue, and therefore the authors doubt whether the implanted cells contribute to the repair process. Dell'Accio and co-workers showed fluorescently labeled, transplanted chondrocytes to be present up to 14 weeks in defects in which the periosteal flap covering the defect was not delaminated. It was also shown that labeled cells contributed to tissue repair, suggesting that these cells are still vital after 14 weeks. The authors showed the absence of transfer of the label to other cells in a nude mice model for 15 days. However, transfer of the label at 14 weeks can not be excluded. Neither Mierisch et al. nor Dell'Accio et al. assessed cell viability specifically and directely. 

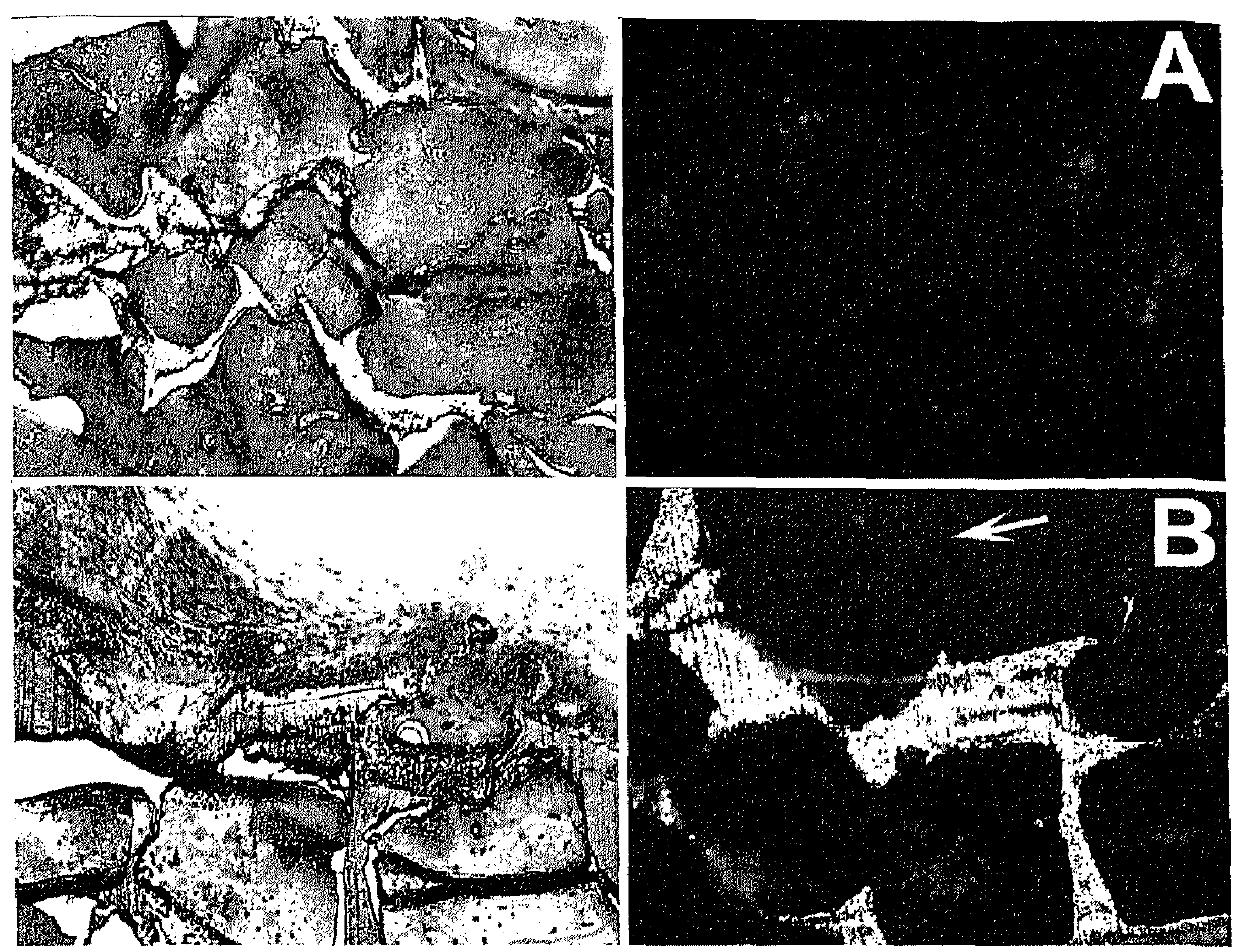

Figure 2. Consecutive GMA sections of compression molded PEGT/PBT polymer scaffolds seeded with CM-DiI labeled rabbit chondrocytes and implanted subcutaneously in a nude mouse. Notice correspondence between the fluorescent CM-DiI labeled chondrocytes clusters (left) and with the thionine stained chondrocytes (right). (A) Five days post-implantation of viable rabbit chondrocytes, no label transfer was detected. (B) Implantation of devitalized rabbit chondrocytes; after seven days some evidence for label transfer was detected. See page 147 for colour figure.

In the present study, a number of experimental conditions were tested to validate the labeling procedure and establish the period in which transfer of label from one cell to another is unlikely. It was concluded, that CM-Dil at a concentration of $40 \mu \mathrm{M}$ is a suitable label for in vivo tracing of chondrocytes and periosteal cells without the risk of transfer of label to endogenous cells for at least 5 days postimplantation. These data are in accordance with earlier data described by Kruyt et al. ${ }^{16}$. The decrease in cell viability up on labeling with CM-DiI from 91 to $76 \%$ was comparable to data described by Andrade et al. and was proven to be due to manipulation of the samples rather than by a direct effect of the CM-DiI fluorochrome ${ }^{25}$.

CM-DiI derivatives have been previously used to label various cell types, including bone marrow cells, lymphocytes, hepatocytes and neural tube cells ${ }^{25-}$ 27, 39. In no instance has an altered cell function or dye cytotoxicity been 

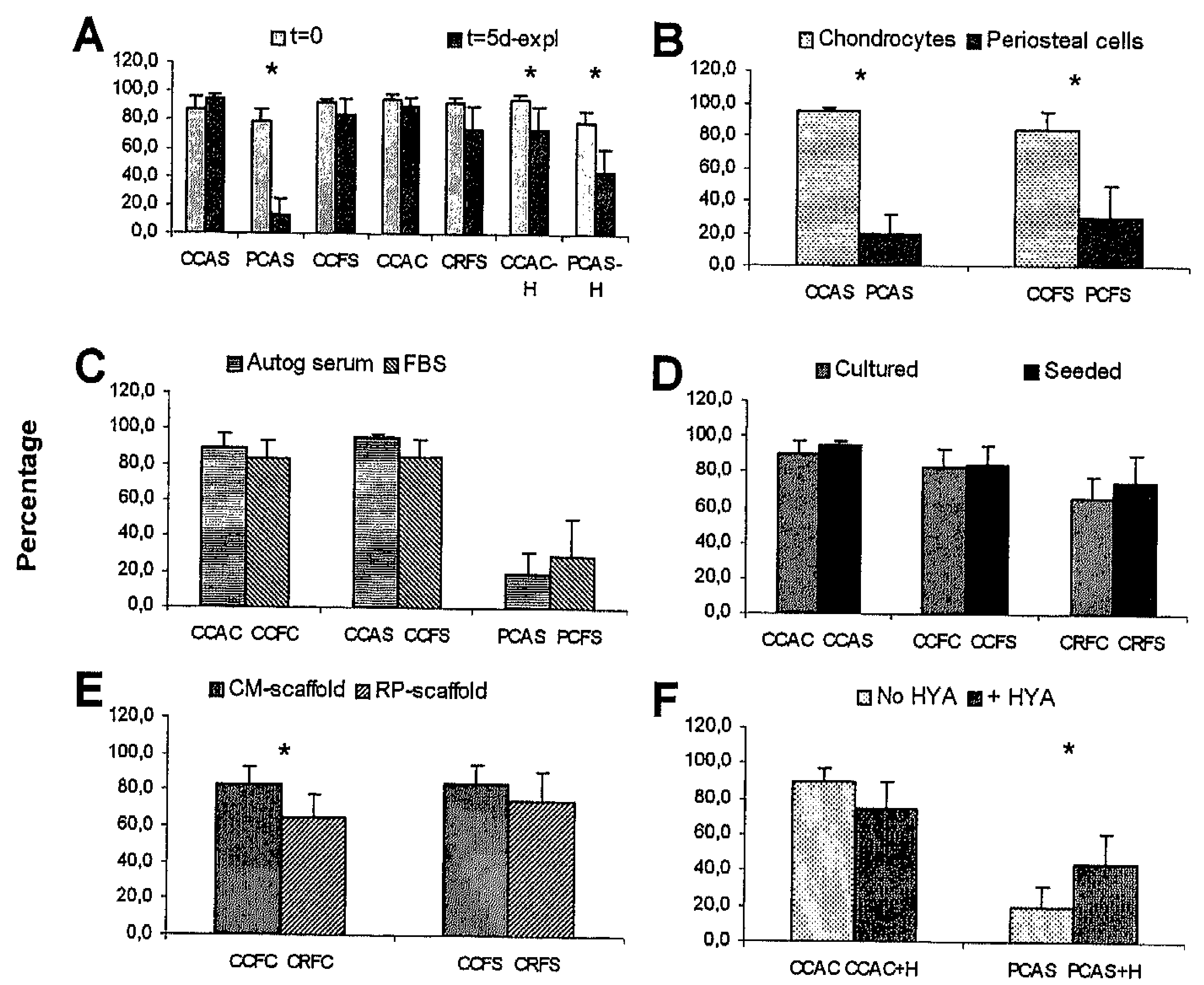

Figure 3. Viability of chondrocytes and periosteal cells after implantation into osteochondral defects. (A) Viability at explantation ( $t=5$ days) compared to that at implantation $(t=0)$. (B) Difference in viability between chondrocytes and periosteal cells. (C) Effect of FBS or AS supplemented to culture medium. (D) Effect of the presence of extracellular matrix. (E) Effect of scaffold pore interconnectivity. (F) Effect of hyaluronan. Codes for the groups are as follows: First letter indicates cell type: C. chondrocytes; P. periosteal cells. Second letter indicates type of scaffold: C. CM scaffold;, R. RP scaffold. Third letter indicates type of serum in culture medium: $F$. FBS; A, AS. Fourth letter indicates seeded (S) or cultured (C) cells in scaffold. 0. analyzed at implantation $(t=0) ; H$. hyaluronan added (see also Table 1$)$. * Significant difference at $p<0.05$.

reported. Analyses of the samples at $\mathrm{t}=0$ of labeled and seeded, but not implanted, cells did not reveal any cytotoxic effects either (internal control). Therefore, we state that the label and the analysis method employed in this study are valid to establish the short term survival of cells in implanted cells-scaffold constructs.

Our interest was primarily in cell viability in the short term. Therefore, we did not test the effect of labeling of periosteal cells on their ability to differentiate into the chondrogenic lineage and of chondrocytes to redifferentiate. 


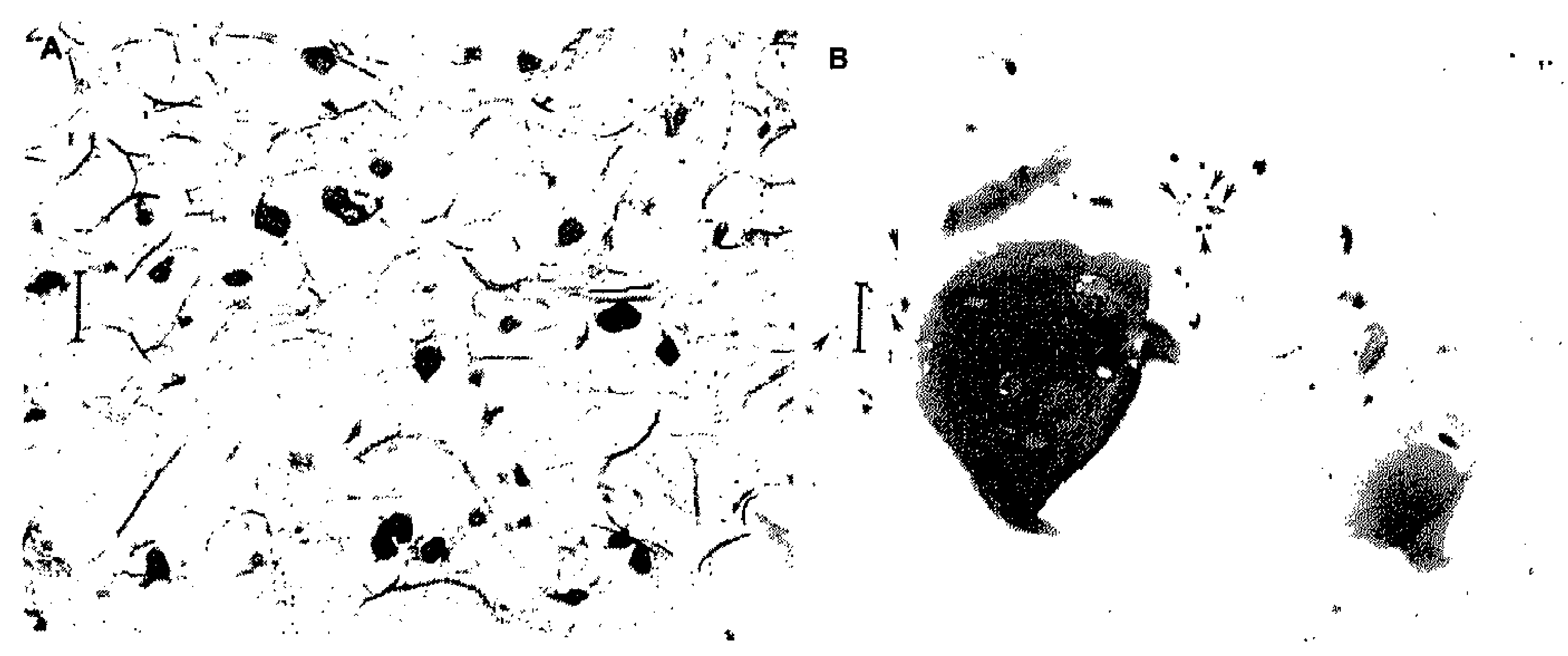

Figure 4. Photographs of a histological section of an explanted cell-scaffold constructs that contained chondrocytes, cultured for 2 weeks within the 3-D CM scaffold. Immediately after implantation, hyaluronan was injected in the knee joint. (A) Overview, showing cartilaginous 'islands' throughout the scaffold. Bar. $\sim 260 \mu \mathrm{m}$. (B) Detail showing apoptotic cells (arrows). Bar. $\sim 32 \mu \mathrm{m}$. See page 147 for colour figure.

Our data did not demonstrate any significant differences in chondrocyte viability between cells cultured in media with FBS and with AS. We conclude that FBS does not reduce cell viability via an immunological reaction (as assessed 5 days post-implantation).

In the present study, the amount of extracellular matrix formed by chondrocytes $^{40}$ prior to implantation did not significantly influence chondrocyte survival. Surprisingly, we did not find differences in chondrocyte viability after seeding in $\mathrm{CM}$ or $\mathrm{PR}$ scaffolds, except in the presence of extracellular matrix. Apparently, nutrient supply and diffusion towards cells within scaffolds does not dependent on scaffold interconnectivity, but on the effect of extracellular matrix in fully interconnected scaffolds. .

HYA increased the number of periosteal cells surviving the implantation. Periosteal cells are known to display MSC characteristics ${ }^{41,42}$ and to express the receptor CD44 for $\mathrm{HYA}^{43}$. HYA may protect periosteal cell from cell death through its CD44 receptor ${ }^{21,44}$. Therefore, the addition of HYA, in combination with the induction of chondrogenic differentiation of progenitor cells prior to implantation, may increase cell viability for bone and cartilage tissue-engineering purposes and requires further research. An increase of chondrocyte viability after administration of HYA was not observed. This was probably due to the high percentage of chondrocytes already surviving the implantation without the addition of HYA, thus masking a potential chondro-protective effect of HYA.

In conclusion, upon implantation in osteochondral defects autogenic chondrocytes survived transfer from culture medium into a osteochondral 
woundbed, whereas most periosteal cells did not. This study indicates the importance of considering initial cell viability upon implantation of a tissueengineered construct.

\section{Acknowledgements}

This study was supported by a grant from Senter (BTS 00021). The help of May Bost, Petra Dijkstra and Monique de Jong from the central animal facility of Maastricht University is gratefully acknowledged.

\section{REFERENCES}

1. Homminga GN, Bulstra SK, Bouwmeester PS, van der Linden AJ. Perichondral grafting for cartilage lesions of the knee.J Bone Joint Surg Br 1990; 72(6): $1003-7$.

2. Homminga GN, van der Linden TJ, Terwindt-Rouwenhorst EA, Drukker J. Repair of articular defects by perichondrial grafts. Experiments in the rabbit. Acta Orthop Scand 1989; $60(3): 326-9$.

3. O'Driscoll SW, Fitzsimmons JS. The role of periosteum in cartilage repair. Clin Orthop 2001(391 Suppl): S190-207.

4. Brittberg M, Lindahl A, Nilsson A, Ohlsson C, Isaksson O, Peterson L. Treatment of deep cartilage defects in the knee with autologous chondrocyte transplantation. $\mathrm{N}$ Engl J Med 1994; 331(14): 889-95.

5. Hangody L, Kish G, Karpati Z, Udvarhelyi I, Szigeti I, Bely M. Mosaicplasty for the treatment of articular cartilage defects: application in clinical practice. Orthopedics 1998; 21(7): 751-6.

6. Hangody L, Kish G, Karpati Z, Szerb I, Udvarhelyi I. Arthroscopic autogenous osteochondral mosaicplasty for the treatment of femoral condylar articular defects. A preliminary report. Knee Surg Sports Traumatol Arthrosc 1997; 5(4): 262-7.

7. Langer R, Vacanti JP. Tissue engineering. Science 1993; 260(5110):920-6.

8. Woodfield TB, Bezemer JM, Pieper JS, van Blitterswijk CA, Riesle J. Scaffolds for tissue engineering of cartilage. Crit Rev Eukaryot Gene Expr 2002; 12(3): 209-36.

9. Solchaga LA, Johnstone B, Yoo JU, Goldberg VM, Caplan AI. High variability in rabbit bone marrow-derived mesenchymal cell preparations. Cell Transplant 1999; 8(5):511-9.

10. Kuijer R, Emans PJ,Jansen EJP, Hulsbosch MM, Surtel DAM, Bulstra SK. Isolation and cultivation of chondrogenic precursors from aged human periosteum. Transactions of the Orthopaedic Research Society 2003; 28: 101.

11. Solchaga LA, Cassiede P, Caplan AI. Different response to osteo-inductive agents in bone marrow- and periosteum-derived cell preparations. Acta Orthop Scand 1998;69(4):426-32.

12. Street J, Winter D, Wang JH, Wakai A, McGuinness A, Redmond HP. Is human fracture hematoma inherently angiogenic? Clin Orthop 2000(378):224-37.

13. Hayes DW, Jr., Brower RL, John KJ. Articular cartilage. Anatomy, injury, and repair. Clin Podiatr Med Surg 2001; 18(1):35-53.

14. Kruyt MC, de Bruijn JD, Wilson CE, Oner FC, van Blitterswijk CA, Verbout AJ, et al. Viable osteogenic cells are obligatory for tissue-engineered ectopic bone formation in goats. Tissue Eng 2003; 9(2): 327-36.

15. Chen AC, Nagrampa JP, Schinagl RM, Lottman LM, Sah RL. Chondrocyte transplantation to articular cartilage explants in vitro. J Orthop Res 1997; 15(6): 791-802. 
16. Kruyt MC, De Bruijn J, Veenhof M, Oner FC, Van Blitterswijk CA, Verbout AJ, et al. Application and limitations of chloromethyl-benzamidodialkylcarbocyanine for tracing cells used in bone Tissue engineering. Tissue Eng 2003; 9(1): 105-15.

17. Gille J, Ehlers EM, Okroi M, Russlies M, Behrens P. Apoptotic chondrocyte death in cellmatrix biocomposites used in autologous chondrocyte transplantation. Ann Anat 2002; 184(4):325-32.

18. Proskuryakov SY, Konoplyannikov AG, Gabai VL. Necrosis: a specific form of programmed cell death? Exp Cell Res 2003;283(1): 1-16.

19. Xu H, Ito $\mathrm{T}$, Tawada $\mathrm{A}$, Maeda $\mathrm{H}$, Yamanokuchi $\mathrm{H}$, Isahara $\mathrm{K}$, et al. Effect of hyaluronan oligosaccharides on the expression of heat shock protein 72. J Biol Chem 2002; 277(19): 17308-14.

20. Wolf D, Schumann J, Koerber K, Kiemer AK, Vollmar AM, Sass G, et al. Low-molecularweight hyaluronic acid induces nuclear factor-kappaB-dependent resistance against tumor necrosis factor alpha-mediated liver injury in mice. Hepatology 2001;34(3):535-47.

21. Lisignoli G, Grassi F, Zini N, Toneguzzi S, Piacentini A, Guidolin D, et al. Anti-Fas-induced apoptosis in chondrocytes reduced by hyaluronan: evidence for CD44 and CD54 (intercellular adhesion molecule 1) invovement. Arthritis Rheum 2001; 44(8): 1800-7.

22. Kirkpatrick CJ, Krump-Konvalinkova V, Unger RE, Bittinger F, Otto M, Peters K. Tissue response and biomaterial integration: the efficacy of in vitro methods. Biomol Eng 2002; $19(2-6): 211-7$.

23. Ferrari A, Hannouche D, Oudina K, Bourguignon $M$, Meunier A, Sedel L, et al. In vivo tracking of bone marrow fibroblasts with fluorescent carbocyanine dye.J Biomed Mater Res 2001; 56(3): 361-7.

24. Andrade WN, Johnston MG, Hay JB. The relationship of blood lymphocytes to the recirculating lymphocyte pool. Blood 1998; 91(5): 1653-61.

25. Andrade W, Seabrook TJ, Johnston MG, Hay JB. The use of the lipophilic fluorochrome CM-Dil for tracking the migration of lymphocytes. J Immunol Methods 1996;194(2): 181 9.

26. Ledley FD, Soriano HE, O'Malley BW, Jr., Lewis D, Darlington GJ, Finegold M. DiI as a marker for cellular transplantation into solid organs. Biotechniques 1992; 13(4): 580, 582, 584-7.

27. Tajbakhsh S, Vivarelli E, Cusella-De Angelis G, Rocancourt D, Buckingham M, Cossu G. A population of myogenic cells derived from the mouse neural tube. Neuron 1994;13(4): 81321.

28. Millard P, Roth B, Kim C. Fluorescence-Based Methods for Microbiol Characterization and Viability Assessment. Biotechnol Int 1997; 1: 291.

29. Merrilees MJ, Beaumont BW, Scott LJ. Fluoroprobe quantification of viable and non-viable cells in human coronary and internal thoracic arteries sampled at autopsy. J Vasc Res 1995; 32(6): 371-7.

30. Poole CA, Brookes NH, Gilbert RT, Beaumont BW, Crowther A, Scott L, et al. Detection of viable and non-viable cells in connective tissue explants using the fixable fluoroprobes 5chloromethylfluorescein diacetate and ethidium homodimer-1. Connect Tissue Res 1996; 33(4): 233-41.

31. Beumer GJ, van Blitterswijk CA, Bakker D, Ponec M. Cell-seeding and in vitro biocompatibility evaluation of polymeric matrices of PEO/PBT copolymers and PLLA. Biomaterials 1993; 14(8): 598-604.

32. Radder AM, Leenders $H$, van Blitterswijk CA. Interface reactions to PEO/PBT copolymers (Polyactive) after implantation in cortical bone. J Biomed Mater Res 1994; 28(2): 141-51. 
Chapter 5

80

33. Malda J, Woodfield TBF, van der Vloodt F, Kooy FK, Martens DE, Tramper J, et al. The effect of PEGT/PBT scaffold architecture on oxygen gradients in tissue engineered cartilaginous constructs. Biomaterials 2004; 25(26): 5773-5780.

34. Gilbert SF, Migeon BR.D-valine as a selective agent for normal human and rodent epithelial cells in culture. Cell 1975; 5(1): 11-7.

35. Ball ST, Goomer RS, Ostrander RV, Tontz WL, Jr., Williams SK, Amiel D. Preincubation of tissue engineered constructs enhances donor cell retention. Clin Orthop 2004(420):276-85.

36. Quintavalla J, Uziel-Fusi S, Yin J, Boehnlein E, Pastor G, Blancuzzi V, et al. Fluorescently labeled mesenchymal stem cells (MSCs) maintain multilineage potential and can be detected following implantation into articular cartilage defects. Biomaterials 2002; 23(1): 109-19.

37. Dell'Accio F, Vanlauwe J, Bellemans J, Neys J, De Bari C, Luyten FP. Expanded phenotypically stable chondrocytes persist in the repair tissue and contribute to cartilage matrix formation and structural integration in a goat model of autologous chondrocyte implantation. J Orthop Res 2003; 21(1): 123-31.

38. Mierisch CM, Wilson HA, Turner MA, Milbrandt TA, Berthoux L, Hammarskjold ML, et al. Chondrocyte transplantation into articular cartilage defects with use of calcium alginate: the fate of the cells. J Bone Joint Surg Am 2003; 85-A(9): 1757-67.

39. Andrade WN, Johnston MG, Hay JB. A method for tracking the migration of blood lymphocytes. Immunol Invest 1996; 25(5-6): 455-67.

40. Malda J, Woodfield TBF, van der Vloodt F, Wilson C, Martens DE, Tramper J, et al. The effect of PEGT/PBT scaffold architecture on the composition of tissue engineered cartilage. Biomaterials 2005; 26(1): 63-72.

41. Ghilzon R, McCulloch CA, Zohar R. Stromal mesenchymal progenitor cells. Leuk Lymphoma 1999; 32(3-4): 211-21.

42. Zohar R, Sodek J, McCulloch CA. Characterization of stromal progenitor cells enriched by flow cytometry. Blood 1997; 90(9):3471-81.

43. Noonan KJ, Stevens JW, Tammi R, Tammi M, Hernandez JA, Midura RJ. Spatial distribution of CD44 and hyaluronan in the proximal tibia of the growing rat.J Orthop Res 1996;14(4):573-81.

44. Pohl M, Sakurai H, Stuart RO, Nigam SK. Role of hyaluronan and CD44 in in vitro branching morphogenesis of ureteric bud cells. Dev Biol 2000; 224(2):312-25. 


\section{In vivo generation of cartilage from periosteum.}

Emans, P.J.,Surtel, D.A.M., Frings, E.J.J., Reilly, K.M., Bulstra, S.K., Kuijer, R. Tissue Eng. 2005 Mar-Apr;11(3-4):369-77. 


\section{ABSTRACT}

Periosteum has chondrogenic and osteogenic potential and plays an important role in fracture healing. The purpose of this study was to evaluate the reactive tissue formed after damaging the periosteum. Dannaging the periosteum may be a way to generate ectopic cartilage or bone, which may be useful for the repair of articular cartilage and bone defects.

Periosteum was bilaterally dissected from the proximal medial tibia of New Zealand white rabbits. Reactive periosteal tissue was harvested at 10,20 and 40 days postsurgery and analyzed for expression of collagen types $1, \pi$ and $\mathrm{X}$, aggrecan, osteopontin and osteonectin (by reverse transcription-polymerase chain reaction) and collagen types I and II (by immunohistochemistry).

Reactive tissue was present in $93 \%$ of the cases. Histologically, this tissue consisted of hyaline cartilage at follow-up days 10 and 20. Expression of collagen type II and aggrecan was present at 10 and 20 days postsurgery. Highest expression was at 10 days. Expression of Collagen Type $\mathrm{X}$ increased up to 20 days. No significant changes in the mRNA expression of osteopontin or osteonectin were observed. Immunohistochemistry confirmed the presence of cartilage, which was positive for collagen types I and II at 10 days and only for collagen type II at 20 days. At 20 days postsurgery the onset of bone formation was also observed At 40 days postsurgery, the reactive tissue had almost completely turned into bone.

The quality and amount of cartilage formed 10 days postsurgery make this technique potentially useful to fill large cartilage and bone defects. Also, periosteal callus formation, providing possible useful information for tissueengineering techniques; can be studied using this model.

\section{INTRODUCTION}

Damaged articular cartilage has a limited ability for intrinsic repair. Chondrogenic lesions do not heal at all and osteochondral lesions heal by the formation of fibrocartilage, which originates from mesenchymal progenitor cells from the bone marrow. New techniques based on tissue engineering have been developed for cartilage repair. Adding of chondrocytes or chrondrogenic progenitors to the cartilage defect may enhance the repair of articular cartilage defects. In techniques such as mosaic plasty (osteochondral autograft transfer system, OATS) and Autologous Chondrocyte Transplantation (ACT) cartilage is harvested from the unloaded part of the joint and either transplanted into the 
defect (OATS) or cells are isolated, expanded in culture, and then transplanted into the defect $(A C T)^{1,2}$. However, using these methods one lesion is repaired by creating another and donor site morbidity has to be taken into account ${ }^{3}$.

It is well known that cells in the cambium layer of periosteum have chondrogenic potential in vitro and in vivo ${ }^{4-10}$. Therefore, these cells may be an alternative cell source for the repair of (osteo)chondral defects without further damaging the joint. The presence of the cambium layer containing the chrondrogenic progenitor cells is essential for this purpose and for in vitro study models, 11-14. However, harvesting periosteum including its cambium layer is difficult and culturing of the cambium layer cells involves expensive and timeconsuming techniques ${ }^{13}, 15,16$. These difficulties may be overcome by inducing the chondrogenesis in cambium layer cells in vivo. In earlier techniques, periosteum derived callus formation was induced by Transforming Growth Factor (TGF)- $\beta 1$ or $\beta 2$ or by Bone morphogenic protein-2 (BMP-2) ${ }^{17-19}$.

It was observed, that after dissection of periosteum from rabbit tibiae the reactive tissue at the donor site appeared, which consisted of a mixture of connective tissue and hyaline-like cartilage. The aim of this study was to investigate this in situ- generated 'cartilage' in more detail, to determine whether this tissue might be useful for repair of articular cartilage lesions. Furthermore, we examined wether this method of producing "reactive tissue" may serve as a model to study periosteal callus formation without the use of exogenous growth factors and without breaking the bone and accessing the bone marrow.

Extraarticular cartilage formation was examined by histology, immunohistochemistry, and semi-quantitative reverse transcription-polymerase chain reaction (RT-PCR) for collagen types I, II, X, aggrecan, osteopontin and osteonectin.

\section{MATERIAL AND METHODS}

\section{Surgical procedures}

Six-month-old female New Zealand White rabbits were used for this study. European and Dutch laws on animal experimentation were strictly followed throughout the study and the animal experimental protocol was approved by the Maastricht University Committee for animal experiments. Surgical procedures were performed under general anesthesia and with the use of sterile techniques. Anesthetic induction was obtained with ketamine hydrochloride (35 $\mathrm{mg} / \mathrm{kg}$ ) and xylazine hydrochloride $(5 \mathrm{mg} / \mathrm{kg}$ ) administered by intramuscular injection. Anesthesia was maintained by means of a mixture of $2 \%$ halothane and oxygen-nitrous oxide delivered by an automatic ventilator using a specially designed mask. Preoperatively, all rabbits received an intramuscular injection 
with antibiotics $(10 \mathrm{mg} / \mathrm{kg}$ ceftiofur sodium, Pharmacia \& Upjohn, Woerden, The Netherlands). Postoperative pain reduction was achieved by administering buphenomorfine $(0.05 \mathrm{mg} / \mathrm{kg})$ intramuscularly for 2 days.

Bilaterally, the skin and the overlying fascia were opened over the upper medial tibia. Periosteum was dissected and a defect of $7 \times 15 \mathrm{~mm}$ was created. This harvested tissue was used to assess expression levels of the genes of interest in undifferentiated periosteum ( $t=0$ days). The overlying fascia was closed with Polysorb 2.0 sutures (Tyco Healthcare, USA). Special care was taken that the tendon of semitendinosus muscle was sutured on top of the lower, short side of the rectangular periosteum defect. Hereafter the skin was closed with Polysorb 4.0 (Tyco Healthcare, USA).

On postoperative days 10,20 and 40 the reactive tissue was harvested. For this purpose the rabbits were anaesthetized as described above. Reactive tissue was dissected with a scalpel or osteotome (40 days). Again, the overlying fascia and skin were closed with Polysorb (Tyco Healthcare, USA). Specimens were weighed and cut in two halves; one part was used for RNA isolation, and the other was fixed in 4\% paraformaldehyde, and either embedded in Tissue Tek (Sakura Finetek USA, Torrance, CA) or dehydrated and embedded in paraffin.

\section{$R N A$ Isolation}

Immediately after harvest, the tissue was frozen in liquid nitrogen and stored at $80^{\circ} \mathrm{C}$. The tissue was pulverized using a Microdismembrator $\mathrm{S}$ (Bauer, Goettingen, Germany). The resulting powder was collected in TriZol reagent and RNA was extracted according to the protocol of the manufacturer (Invitrogen, Breda, The Netherlands). Quantity and purity were determined by reading the absorbance at 260 and $280 \mathrm{~nm}$. The RNA samples were subjected to RNase-free DNase digestion to remove any genomic DNA and to agarose gel electrophoresis to assess the intactness of RNA. Removal of DNA was checked by PCR.

\section{Reverse Transcription-Polymerase Chain Reaction}

Expression of the different genes was determined by RT-PCR. Two hundred nanograms of heat-denatured RNA were reverse transcribed with $100 \mathrm{U}$ mouse mammary leukemia virus (MMLV) reverse transcriptase (Promega, Madison, WI) in $50 \mathrm{mM}$ Tris- $\mathrm{HCl}$ ( $\mathrm{pH}$ 8.3), $75 \mathrm{mM} \mathrm{KCl,} 3 \mathrm{mM} \mathrm{MgCl}{ }_{2}$ and 10 U RNAsin (Promega). Two $\mu \mathrm{L}$ of $\mathrm{c}-\mathrm{DNA}$ from each sample was amplified in $10 \mu \mathrm{L}$ of PCR mixture. Specific primers and protocols were used as described in Table 1. Human primers were used for amplifying fragments of rabbit collagen type I and type X cDNA (Table 1). Sequences of the newly formed rabbit collagen type I and type X DNAs were compared with the human sequences of collagen type I and type X. Expression levels of the following genes were inves- 
Table 1: PCR primers

\begin{tabular}{|c|c|c|c|c|}
\hline cDNA & $\begin{array}{l}\text { Product } \\
\text { size }(b p)\end{array}$ & Primer sequence & & $\begin{array}{l}\text { Genbank number } \\
\text { or reference }\end{array}$ \\
\hline $\begin{array}{l}\text { Collagen Type I a } \\
\text { (human) }\end{array}$ & 551 & $\begin{array}{l}\text { 5'GGCCACGCTGTTCTTGCAGT3' } \\
\text { 5'CCAGCGCTGGTTTCGACTTC3' }\end{array}$ & $\begin{array}{l}S \\
\text { AS }\end{array}$ & AY633663 \\
\hline Collagen Type II b & 366 & $\begin{array}{l}\text { 5'GCACCCATGGACATTGGAGGG3' } \\
\text { 5'GACACGGAGTAGCACCATCG3' }\end{array}$ & $\begin{array}{l}\mathrm{S} \\
\mathrm{AS}\end{array}$ & $\begin{array}{l}\text { Hellio Le Graverand } \\
\text { et al. } 30,31\end{array}$ \\
\hline $\begin{array}{l}\text { Collagen Type X c } \\
\text { (human) }\end{array}$ & 329 & $\begin{array}{l}\text { 5'ACAGGAATGCCTGTGTCTGCTTTT3' } \\
\text { 5'TTGGGAAGCTGGAGCCACACCTGGTC3' }\end{array}$ & AS & AY598937 \\
\hline Aggrecan & 313 & $\begin{array}{l}\text { 5'GAGGAGATGGAGGGTGAGGTCTT'T3' } \\
\text { 5'CTTCGCCTGTGTAGCAGATG3' }\end{array}$ & $\begin{array}{l}S \\
\text { AS }\end{array}$ & L38480 \\
\hline Osteopontin & 247 & $\begin{array}{l}\text { 5'GCTCAGCACCTGAATGTACC3' } \\
\text { 5'CTTCGGCTCGATGGCTAGC3' }\end{array}$ & $\begin{array}{l}\mathrm{S} \\
\mathrm{AS}\end{array}$ & $\begin{array}{l}\text { D16544 } \\
\text { Morone et al.32 }\end{array}$ \\
\hline Osteonectin & 369 & $\begin{array}{l}\text { 5'CTCCAGCTGGACTACATCG3' } \\
\text { 5'CTCCATGGGGATGAGTGGT3' }\end{array}$ & $\begin{array}{l}\mathrm{S} \\
\mathrm{AS}\end{array}$ & $\begin{array}{l}\text { AF247647 } \\
\text { Morone et al.32 }\end{array}$ \\
\hline GAPDH & 293 & $\begin{array}{l}\text { 5'TCACCATCTTCCAGGAGCGA3' } \\
\text { 5'CACAATGCCGAAGTGGTCGT3' }\end{array}$ & $\begin{array}{l}S \\
\text { AS }\end{array}$ & L23961 \\
\hline $\begin{array}{l}\text { Beta-actin } \\
\text { (human) }\end{array}$ & 294 & $\begin{array}{l}\text { 5'CAGCGGAACCGCTCATTGCCAATGG3' } \\
\text { 5'TCACCCACACTGTGCCCATCTACGA3' }\end{array}$ & $\begin{array}{l}S \\
\text { AS } \\
\end{array}$ & AY598932 \\
\hline
\end{tabular}

Abbreviations: AS, antisense; S, sense. ${ }^{\mathrm{a}}$ Human-specific primers were used for collagen types I and X. The amplified products revealed $91 \%$ homology for human collagen type I and $96 \%$ homology for human collagen type X with. Most primers were developed in house, based on the gene sequence obtained from Genbank or the reference given, using the Primer 3 software (available on the internet); ${ }^{b}$ See Refs. 30 and $31 ;{ }^{c}$ See Ref. 32.

tigated: collagen type I, collagen type II, collagen type $\mathrm{X}$, aggrecan, osteonectin, glyceraldehyde-3-phosphate Dehydrogenase (GAPDH), and $\beta$-Actin.

Eight $\mu \mathrm{L}$ of each PCR sample was run on a $2 \%$ agarose gel containing ethidiumbromide $(0.5 \mathrm{mg} / \mathrm{mL})$. Positive bands were visualized and quantified with a Geldoc 1000 system using Molecular Analyst software (Bio-Rad, Hercules, CA). Values are expressed as a ratio to $\beta$-Actin.

\section{Staining protocols}

Paraffin sections were dewaxed, hydrated and stained with thionine for 10 minutes. After being washed and dried, coverslips were mounted with Entellan (Merck, Darmstad, Germany).

For immunostaining of collagen type I and for staining of endogenous alkaline phosphatase (ALP), cryosections were fixed in acetone at $4^{\circ} \mathrm{C}$ for 10 minutes. For staining with anti-collagen type II antibody, paraffin-embedded sections were dewaxed and hydrated. Culture supernatants containing primary antibodies were diluted in phosphate-buffered saline (PBS) as follows: mouse monoclonal anti-collagen type I (M38, diluted 1:50; Developmental Studies 


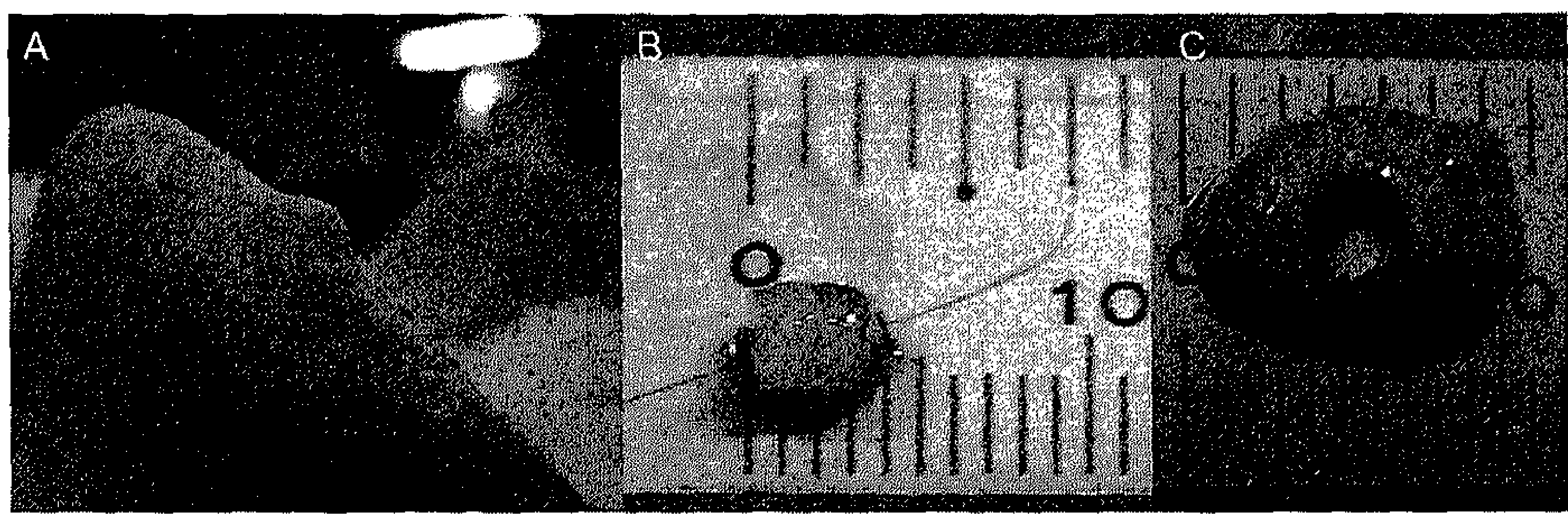

Figure 1. (A) In vivo generation of cartilage from periosteum (COP) at the upper medial part of the right tibia of a rabbit, 10 days post surgery. (B) A cartilage construct $(3 \mathrm{~mm}$ thick and $3 \mathrm{~mm}$ in diameter) cored out of $(\mathrm{C})$ a large sample, resected 10 days postsurgery.

Hybridoma Bank [DSHB], University of Iowa, Iowa City, IA) and mouse monoclonal anti-collagen type II (II-II6B3, diluted 1:50; DSHB).

After incubation with the primary antibody, sections were washed with PBS and incubated with the secondary antibody (horseradish peroxidase [HRP]conjugated rabbit anti-mouse; ITK Diagnostics, Uithoorn, The Netherlands). Diaminobenzidine $(\mathrm{DAB})$ was used as a substrate for peroxidase. To assess the presence of ALP, cryo sections were incubated for 10 minutes with Vectastain (Vector Laboratories, Burlingame, CA)

\section{STATISTICAL ANALYSIS}

Analysis of differences in mRNA levels between the time points was performed using the Mann-Whitney $U$ test. Statistical significance was tested for $p<0.05$.

\section{RESULTS}

\section{General observations}

After dissection of the periosteum, the rabbits recovered and were well; no adverse effects were observed. Reactive tissue, appearing first as a thickening, in time turned from soft to hard tissue and was observed in $93 \%$ of the rabbits (Fig. 1A). The size of the reactive tissue was variable (range, $4-10 \mathrm{~mm}$ in diameter and $1.5-2.5 \mathrm{~mm}$ in thickness). Within one animal the periosteal reaction could differ, being absent on one side and a large reaction (7 $\mathrm{mm}$ in diameter) on the other side. In general, the reactive tissue originated from periosteum damaged at the distal short side $(7 \mathrm{~mm})$ of the rectangle. At 10 days the tissue could easily be removed and a desired shape could easily be cored out of the whole piece of reactive tissue (Fig. $1 \mathrm{~B}$ and $\mathrm{C}$ ); at 20 days the tissue was harder, more 


\section{A}

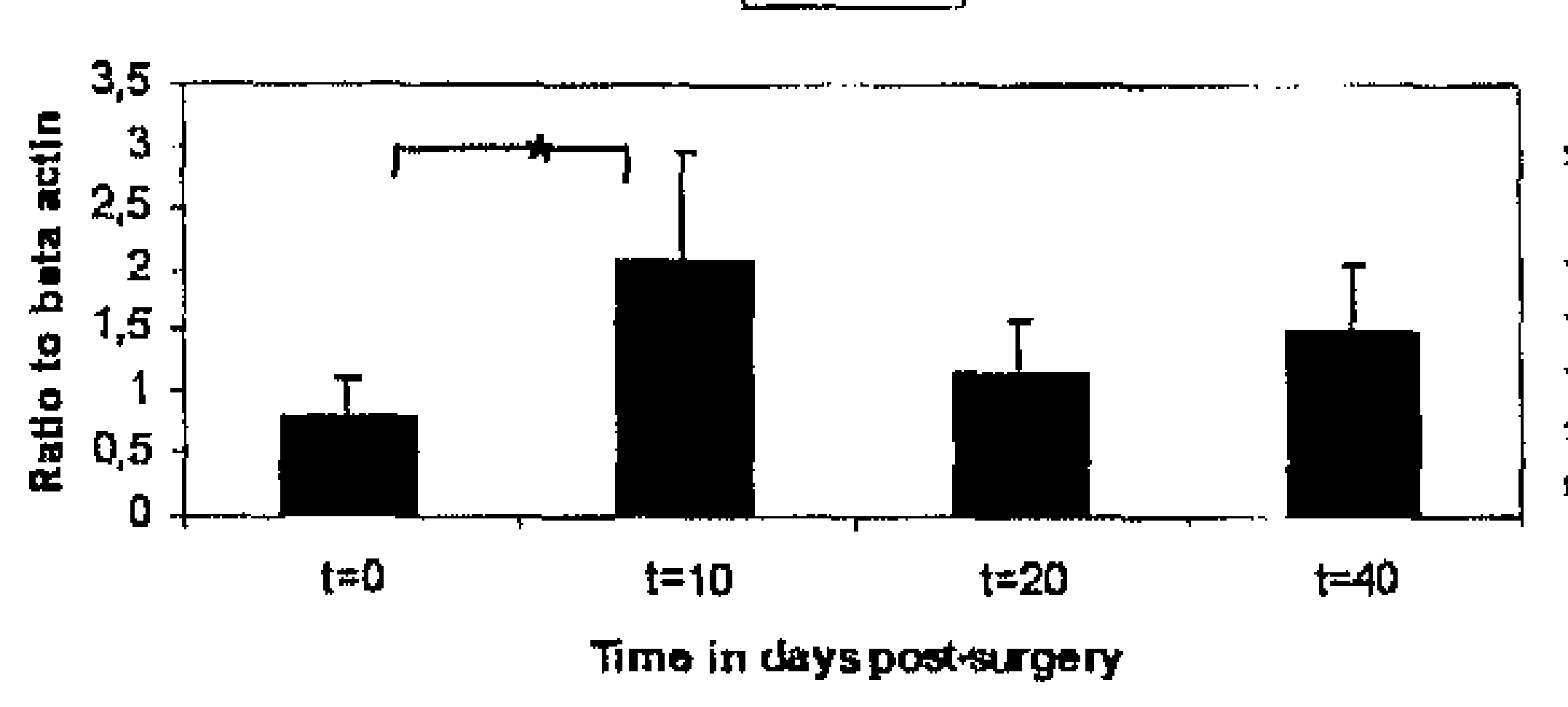

C

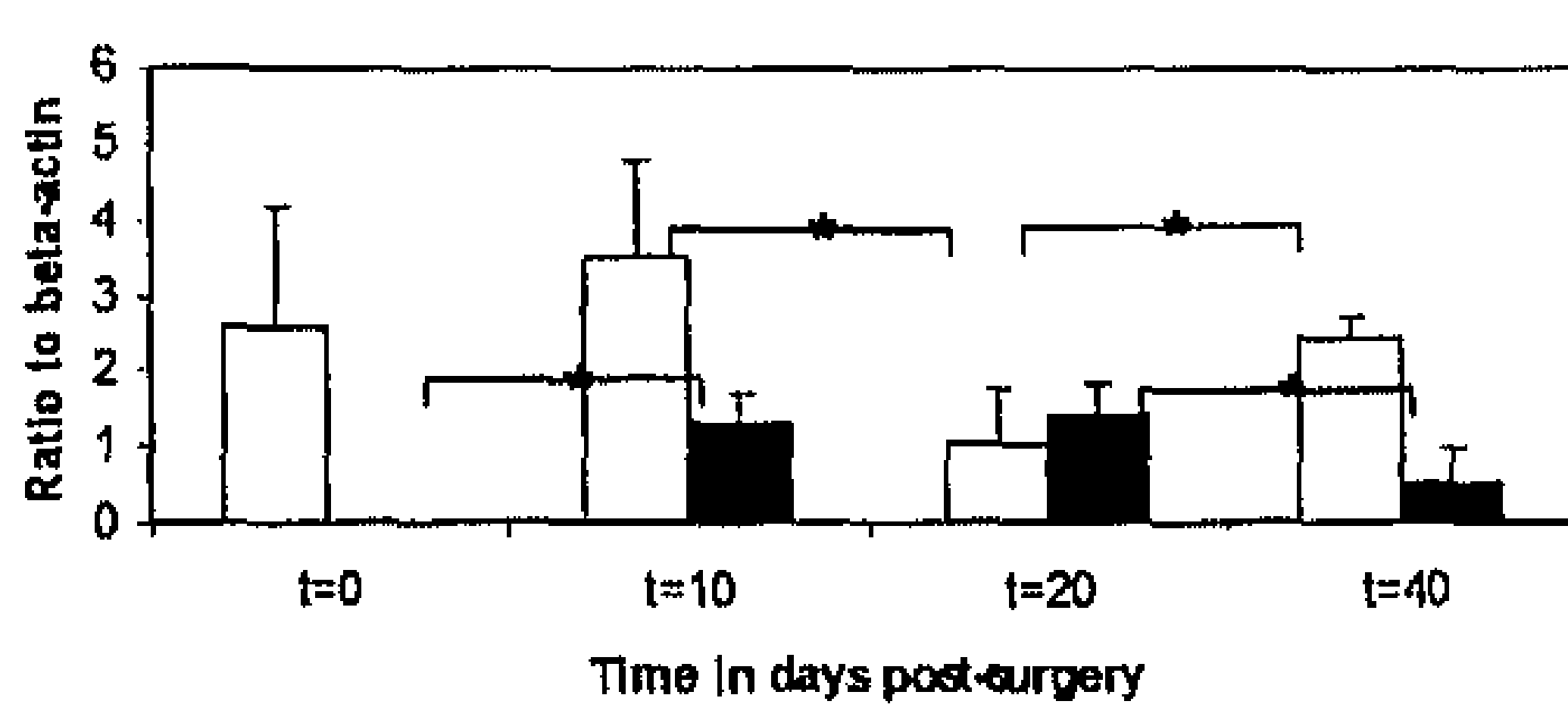

B OAgrecan I Codiagen Typell

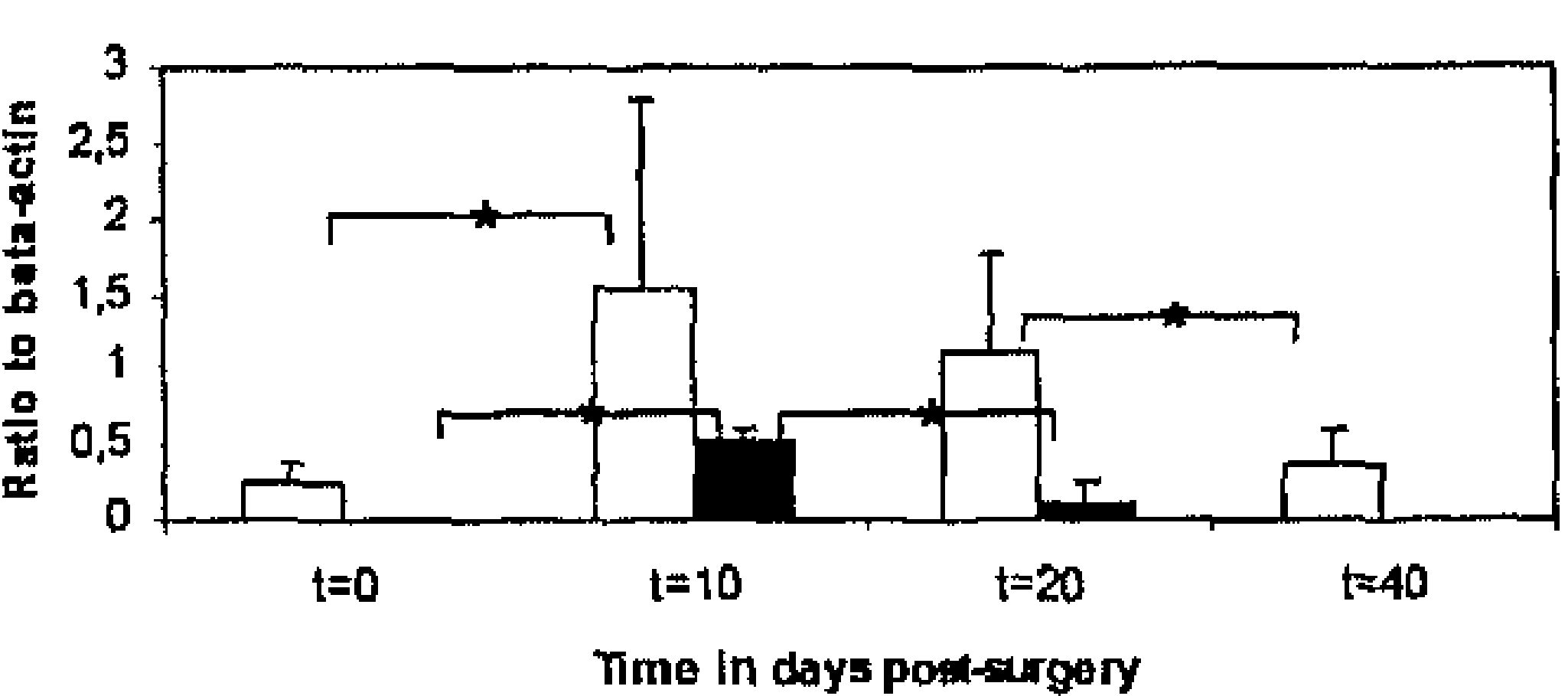

D [OSteonectin COsteopontin]

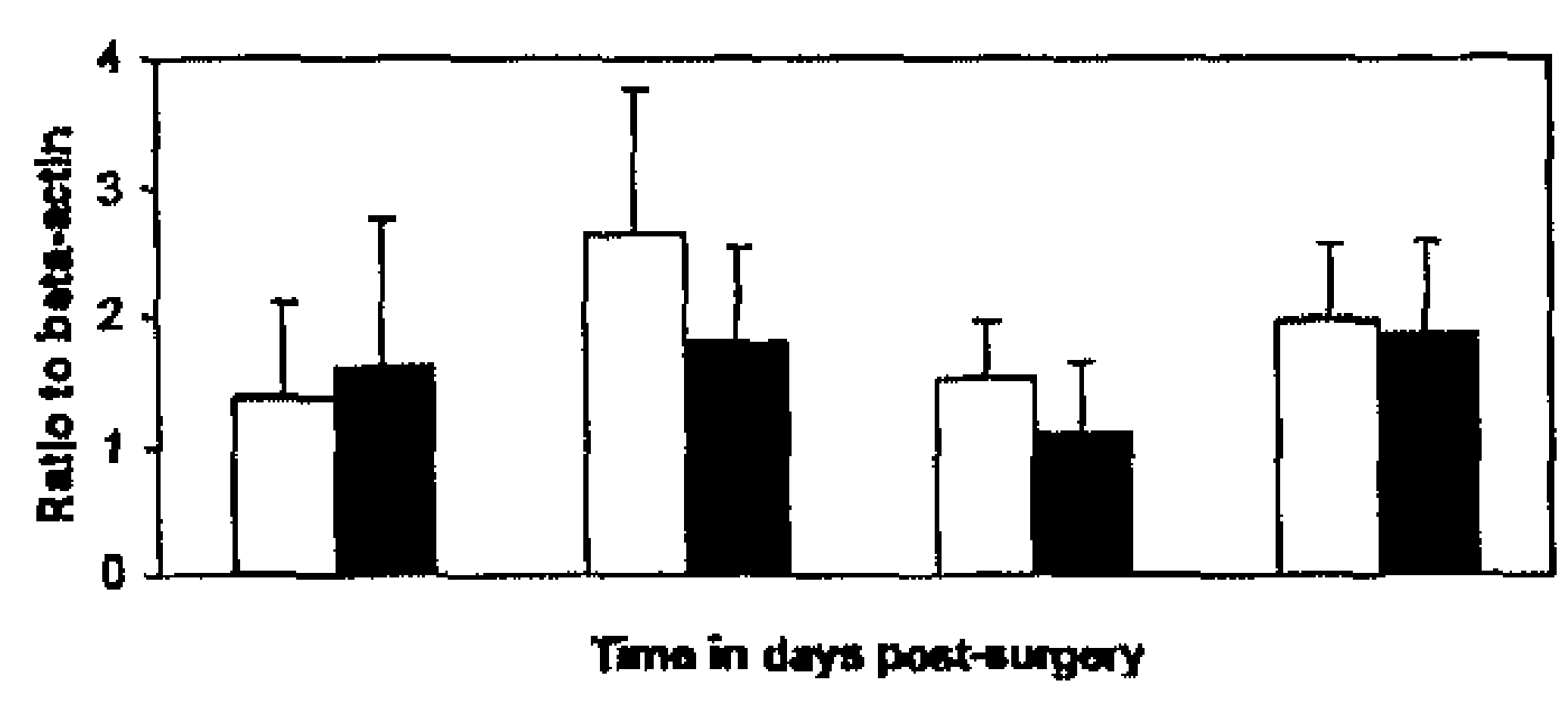

Figure 2. Histograms presenting relative mRNA levels compared to the level of $\beta$-actin mRNA during chondrogenic and osteogenic differentiation of reactive tissue produced by dissection of periosteum. (A) The expression of GAPDH; (B) expression of aggrecan and collagen type II, (C) expression of collagen type I and collagen type $X$; and (D) expression of osteopontin and osteonectin. * Statistically significant at $\mathrm{p}<0.05$.

vascularized and more difficult to remove, and finally after 40 days the tissue was very hard, highly vascularized, and had to be removed with an osteotome. Macroscopically, the tissue at 10 and 20 days consisted of a cartilage-like tissue covered by fibrous and inflammatory tissue still containing remnants of the suture. The size of the cartilaginous tissue was sufficient to fill an osteochondral defect with a size of $4 \mathrm{~mm}$ diameter and $2 \mathrm{~mm}$ deep (Fig. 1B and C).

\section{Semi-quantitative $m R N A$ expression}

The sequence of the PCR fragment of rabbit collagen type I CDNA was $91 \%$ identical to the human sequence. The PCR fragment of rabbit collagen type $\mathrm{X}$ cDNA revealed $96 \%$ homology with the corresponding human sequence.

Both $\beta$-actin and GAPDH were considered as internal control. RT-PCRs for both $\mathrm{mRNAs}$ were performed in 30-fold. After agarose gel electrophoresis in the presence of ethidium bromide band densities were assessed and averaged. The expression level of GAPDH increased in tissues from $t=0$ to $t=10$ days whereas the band density per ng cDNA for $\beta$-actin remained stable during follow-up The average expression of GAPDH (expressed as ratio to $\beta$-actin) increased 2.52 times (Fig. 2A). $\beta$-actin was used as internal control.

In periosteum the mRNAs for aggrecan, collagen type II and type $X$ were not expressed, or expressed at a low level. Up-regulation of mRNAs for 


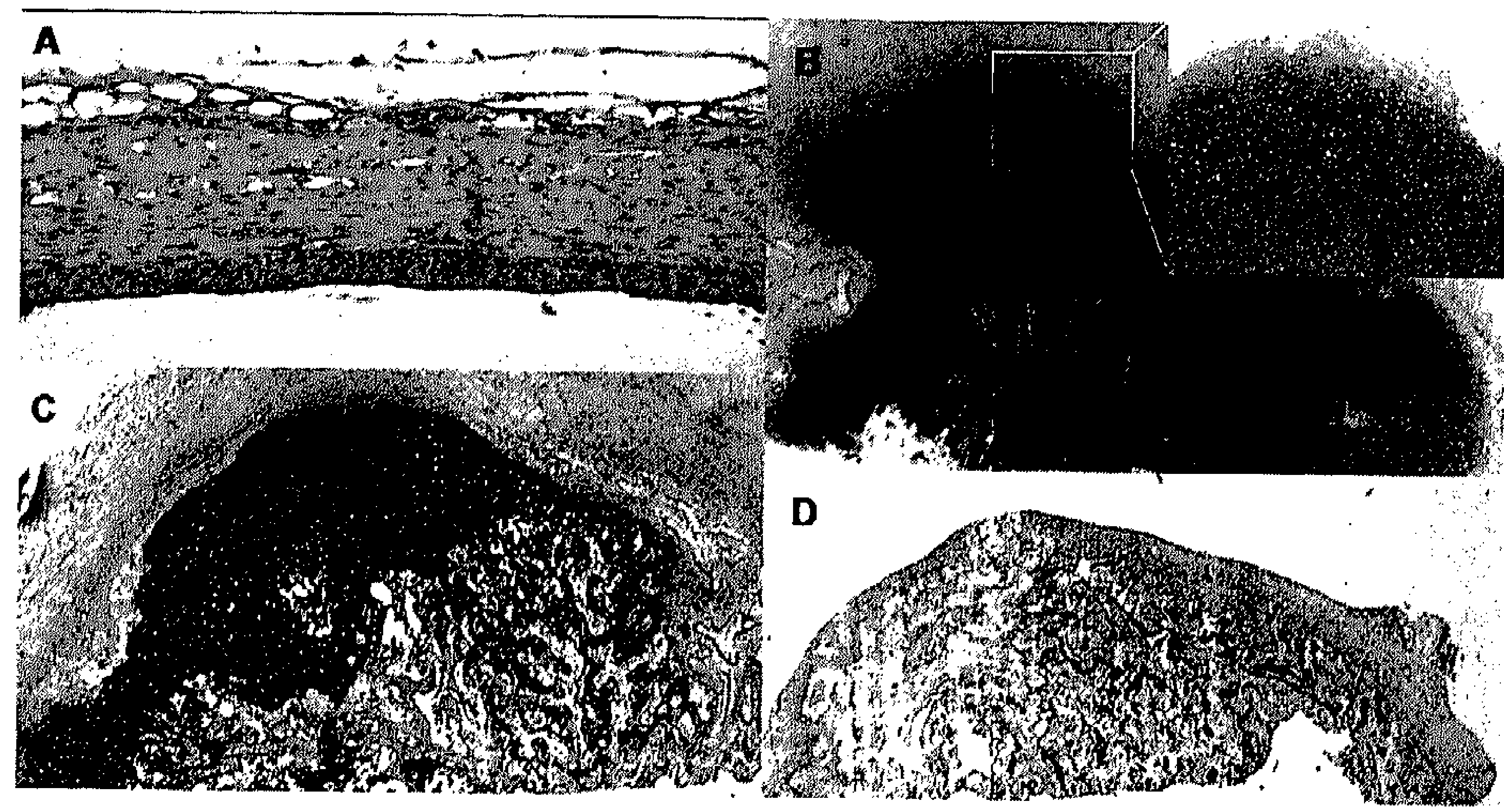

Figure 3. Histological sections stained with thionine. (A) Rabbit periosteum (day 0): note the (lower) cambium layer (B) Ten days postsurgery; a large piece of cartilage is differentiated from the cambium cells (see insert). (C) Twenty days postsurgery; numerous chondrocytes are hypertrophic Bone and newly formed bone marrow are seen. (D) Forty days post-surgery; the cartilage is almost completely differentiated into bone, remnants of the cartilage matrix still being visible. Original magnification (A) x 100: (B) X 16: (C) X16; insert in (B). X 100. See page 148 for colour figure.

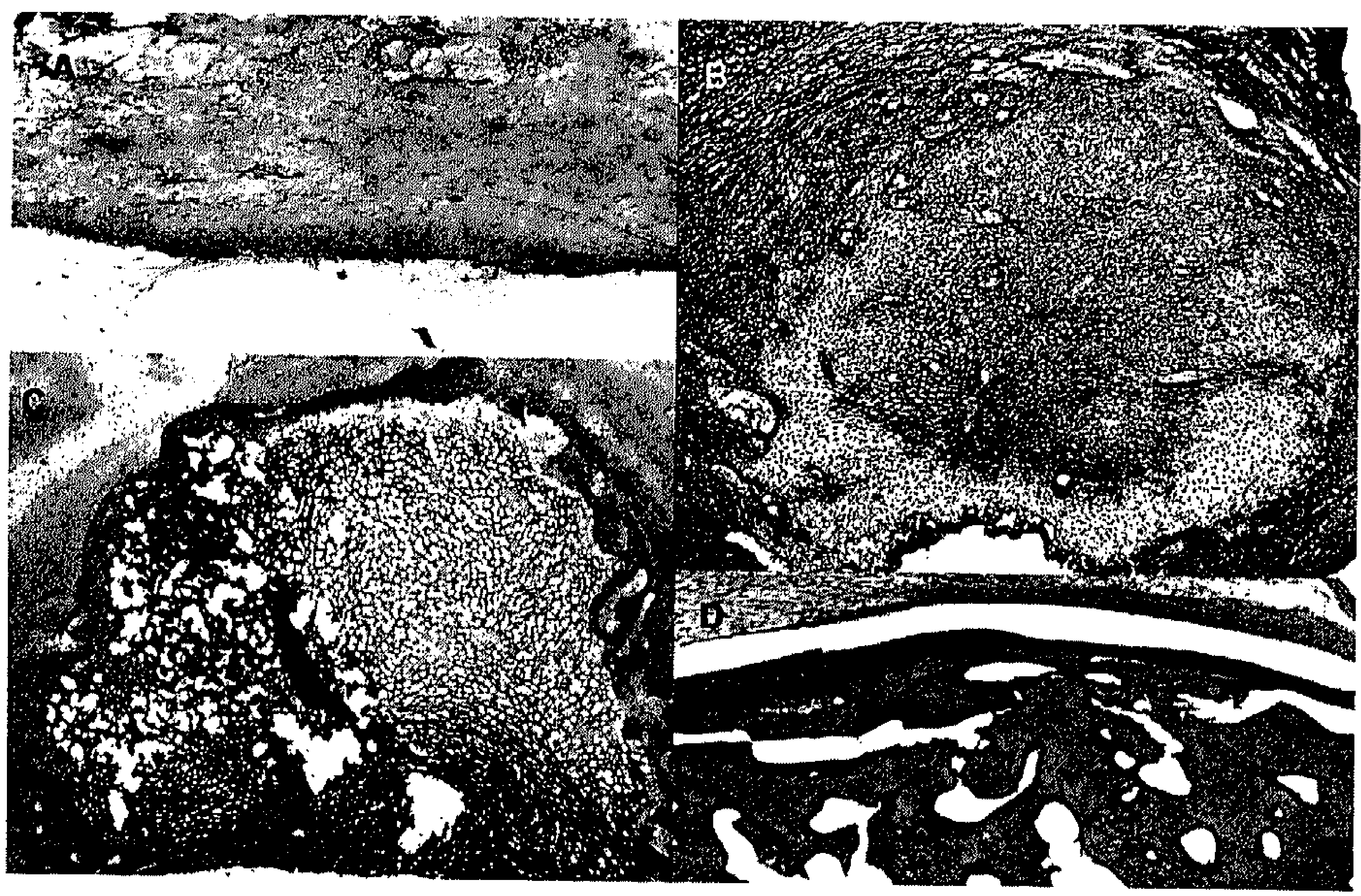

Figure 4. Histological sections stained with antibodies for collagen type I and counterstained with haematoxylin. (A) In periosteum (day 0) the cambium layer stains positive. (B) Collagen type $\mathrm{I}$ is detectable in the newly formed cartilaginous tissue 10 days postsurgery. (C) At 20 days postsurgery, negative staining for collagen type $I$ in the cartilaginous tissue. (D) Forty days postsurgery, collagen type I is slightly detectable. Orignal magnification: (A) X 100; (B) X 16; (C) $\mathrm{X} 16$; (D) $\mathrm{X} 16$. 
aggrecan, collagen types II and $\mathrm{X}$ was seen in all $\mathrm{t}=10$ day samples (Fig. $2 \mathrm{~B}$ and C).

Collagen type I, osteopontin and osteonectin mRNAs were expressed in periosteum. Collagen type I expression was downregulated at 20 days postsurgery. No significant changes in the expressions of osteopontin and osteonectin were observed in time (Fig. 2D). At 40 days postsurgery collagen type II expression was absent. mRNAs for collagen type I, collagen type X, and aggrecan continued to be expressed at a low level (Fig. $2 \mathrm{~B}$ and C).

\section{Thionine and Immunohistochemical staining}

Thionine staining confirmed the presence of a homologous piece of hyalinelike cartilage 10 days postoperation. At 20 days a gradual transformation towards bone was observed, originating from the deep layer of the reactive periosteal tissue. At 40 days the reactive tissue was almost completely transformed into bone (Fig. 3 A-D).

Immunohistochemistry reflected the observed gene expression of collagen types I and II. Collagen type I staining was seen in the cambium layer of periosteum $(t=0)$, this collagen was also present in the newly formed cartilage at $\mathrm{t}=10$ days. At $\mathrm{t}=20$ days collagen type I could not be detected in the cartilage anymore. In the newly formed bone ( $t=40$ days), collagen type I was seen (Fig. 4 A-D).

Collagen type II was absent in periosteum (day 0). At $t=10$ and $t=20$ days collagen type II was observed in the newly formed cartilage. Forty days postsurgery, remnants of collagen type II were still seen in the newly formed, trabecular bone (Fig. 5 A-D).

Endogenous ALP was specifically seen in the cambium layer of periosteum $(t=0)$. During the process of periosteal callus formation, the hypertrophic chondrocytes and newly formed bone stained positive for ALP. No ALP was detected in the young chondrocytes. (Fig. $6 \mathrm{~A}$ and B).

\section{DISCUSSION}

In this study it is demonstrated that damage of periosteum can result in the formation of ectopic cartilage, which subsequently is transformed into bone. During the formation of cartilaginous tissue the expression levels of aggrecan, collagen type II and collagen type $\mathrm{X}$ increase. During the osteogenic process the expression levels of collagen type I and collagen type II decrease, whereas the mRNAs of collagen type $X$ and aggrecan continue to be up-regulated. No significant up- or downregulation of osteonectin or osteopontin expression was 
90

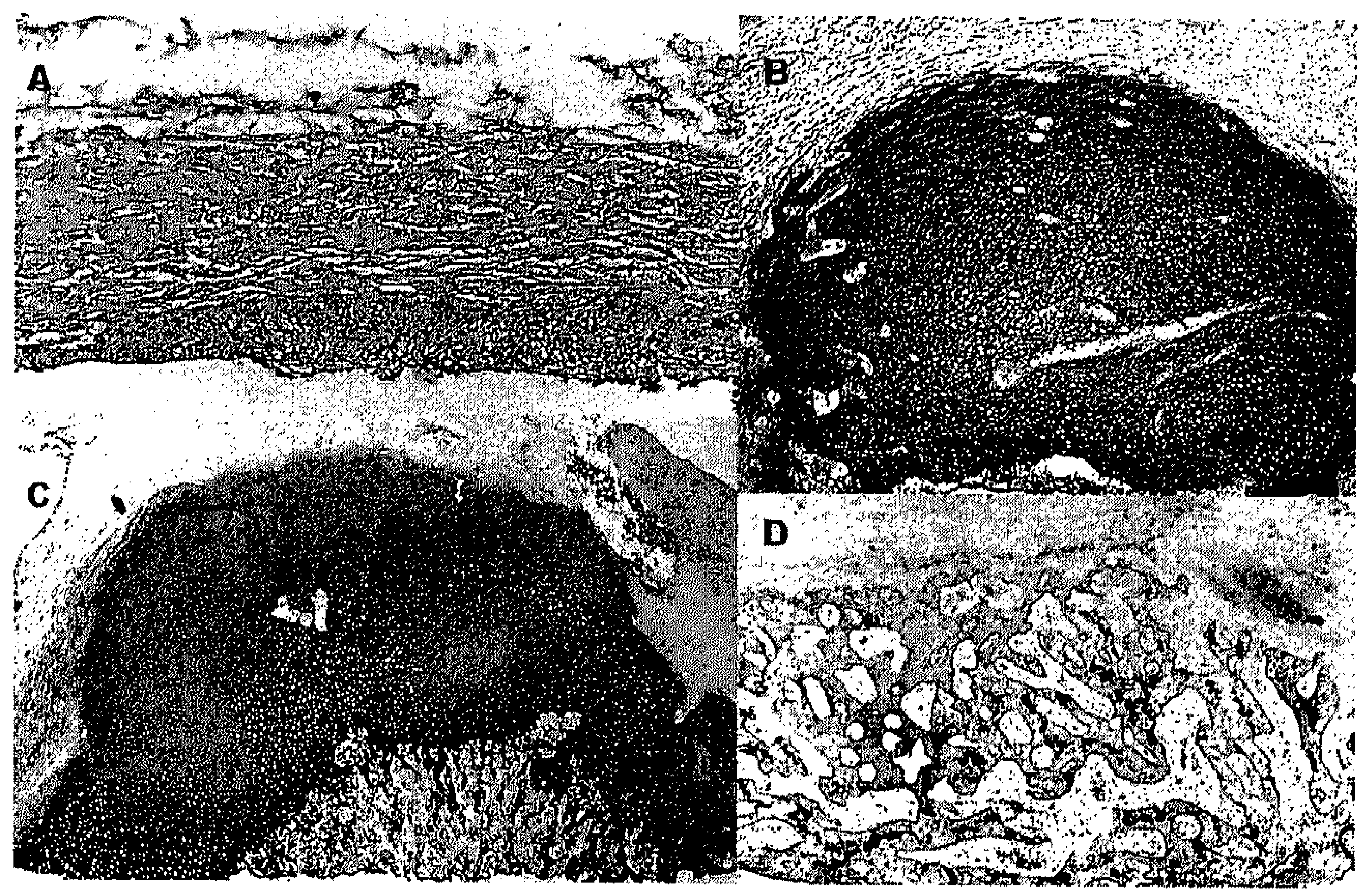

Figure 5. Histological sections stained with antibodies for collagen type II and counterstained with haematoxylin. (A) Negative staining in periosteum (day 0). (B) Ten days postsurgery the cartilaginous tissue stained positive. (C) During new bone formation the presence of collagen type II decreased. (D) Forty days postsurgery, remnants of collagen type II are still visible within the bone tissue. Original magnification: (A) X 100; (B) X 16; (C) X 16; (D) X16.

observed. The observed tissue differentiation resembles the process described for endochondral bone formation ${ }^{20,21}$.

We observed an increase in the expression level of GAPDH between $t=0$ and $\mathrm{t}=10$ and a decrease between $\mathrm{t}=20$ and $\mathrm{t}=40$ days. These changes are probably due to a more anaerobic metabolism in cartilage, where energy has to be generated by glycolysis. GAPDH is an essential enzyme in this pathway and the observed increase of the mRNA for this enzyme is supportive for a change towards anaerobic dissimilation (positive Pasteur Effect). Because periosteum $(t=0)$ and bone $(t=40)$ are vascularized tissues, in which more aerobic metabolism is present, the transient effect is also supportive for a change towards an anaerobic metabolism during periosteal chondrogenesis. Reports describing a Pasteur effect in articular cartilage $e^{22,23}$ are contradicted by an article describing a negative Pasteur effect ${ }^{24}$. The observed increase in GAPDH is supportive for a positive Pasteur Effect (increase in glycolysis); however, conclusive evidence is not presented in this study.

It is important to note that the choice of the housekeeping gene as an internal standard in RT-PCR studies on chondrogenic differentiation should be carefully considered. 


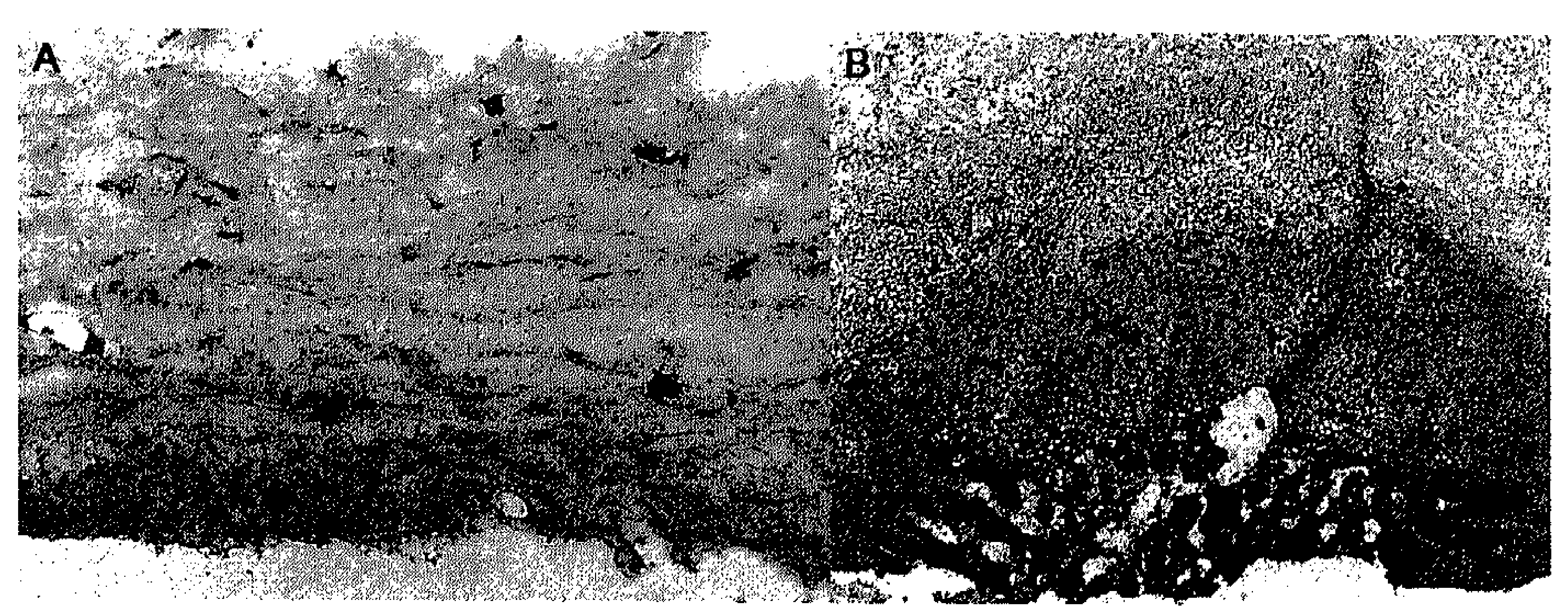

Figure 6. Histological sections stained for the presence of alkaline phosphatase activity. (A) endogenous Alkaline Phosphatase (ALP) in the cambium layer of periosteum. (B) Intense staining for endogenous ALP in bone, less staining intensity in hypertrophic chondrocytes, and absence of ALP activity in young chondrocytes. Original magnification: (A) X 400; (B) X 50. See page 148 for colour figure.

In $7 \%$ of the cases no cartilage from periosteum was observed and, because it was noticed that in one animal such formation was present on one side and absent on the other, the authors suggest that the technique of inducing reactive tissue was essential. The optimal technique of inducing periosteal chondrogenesis still has to be determined. The method of damaging the periosteum, the age of the animal or patient and the role of mechanical factors, growth factors, and hypoxia remain unknown and need further investigation. Moreover, harvesting periosteum may not be the best method to induce periosteal callus formation because differentiation derives from periosteal progenitor cells that remain in situ. If periosteum is harvested, precursors in the harvested piece are prevented from differentiating in vivo and therefore the number of precursors in vivo is probably not optimal.

In a pilot study, it was observed that in the majority of cases, cartilaginous differentiation was only observed at the lower short side of the rectangular defect. The overlying semitendinosus muscle and the mechanical forces induced by it and by the sutures distinguish this side from the other 3 sides of the defect. Therefore the authors suggest that this might be an important factor for inducing cartilaginous differentiation.

The age of the patient and site and size of periosteal resection influence the number of chondrogenic progenitors in the cambium layer of periosteum ${ }^{12,14}$. Awareness of these factors may be essential for successful generation of cartilage from periosteum. In particular, the age of the patient could be a limiting factor in successful generation of cartilage from periosteum. Because of the lower number of chondrogenic precursors in the periosteum of aged patients, 
Chapter 6

92

harvesting, isolating and culturing these cells are hampered in these patients ${ }^{7}$. However, periosteum of aged patients still contains chondrogenic precursors and, using the principle of the 'in situ incubator', the chondrogenic precursors may very well differentiate in vivo and difficulties with harvesting, isolating, and culturing of these cells are bypassed ${ }^{15}$.

The in situ incubator for periosteal cells has already been reported by others ${ }^{25-27}$. However, in these studies the tissue was not harvested in its cartilaginous stage and periosteal release in goats resulted in an almost immediate osteogenesis ${ }^{26,27}$.

In rabbits partial dissection of periosteum is a fast method to generate completely autologous extraarticular cartilage. If this method can be reproduced in humans it might prove useful for the repair of both (osteo)chondral and bone defects.

The amount of cartilage formed was sufficient to repair large defects in the rabbit (4 $\mathrm{mm}$ in diameter, i.e. the width of a femoral condyle) and the size and shape could easily be cored out of the whole piece of reactive tissue 10 days postsurgery. The ideal timing for harvesting COP for transplantation or tissueengineering purposes had to be determined; technical surgical factors, vascularization of the reactive tissue and stage of differentiation play important roles. Our data suggest that, in this rabbit model COP formed between 10 and 20 days post-surgery may be useful to repair bone and/or cartilage defects.

In fracture healing periosteal cells, endosteal cells and Bone Marrow Cells (BMC's) contribute to callus formation ${ }^{28}$. Although bone marrow is often considered to be the main source of osteochondrol progenitor cells, our study suggests, in accordance to earlier reports, that periosteum plays an important role in providing undifferentiated mesenchymal cells for callus formation ${ }^{19,29}$. Because in the presented model periosteum is damaged without breaking the bone and accessing the bone marrow, this model can be used to study the role of periosteum during cartilage and endochondral bone formation, providing information that may be useful for tissue engineering of cartilage and or bone and for fracture healing.

In conclusion, dissection of periosteum of the rabbit tibia resulted in the generation of a cartilaginous tissue within $10-20$ days of the dissection procedure. The tissue consisted of hyaline cartilage covered with connective tissue, which can easily be removed after dissection. Forty days after dissection the tissue has completely turned into bone. The amount of tissue at 10 or 20 days postsurgery is sufficient to resurface a complete femoral condyle of a rabbit.

Dissection of periosteum is an inexpensive and fast method to produce enough homologous cartilaginous tissue for the restoration of cartilage defects. The procedure is completely autogenic and does not require expensive and 
infection-prone culture techniques. Also, the use of artificial scaffolds is not necessary.

Whether dissection of periosteum is the optimal way to induce ectopic cartilage formation has to be determined. This procedure of inducing ectopic cartilage and bone can be used as a model to study periosteal callus formation.

\section{Acknowledgements}

This study was supported by a grant from Senter (BTS 00021). The help of May Bost, Petra Dijkstra and Monique de Jong (experimental animal facility of Maastricht University) is gratefully acknowledged. The monoclonal antibodies developed by T.F. Linsenmayer et al. (II-II6B3) and McDonald et al. (M38) were obtained from the Developmental Studies Hybridoma Bank developed under auspices of the NICHD and maintained by the Department of Biological Sciences of the University of Iowa IowaCity, IA).

\section{REFERENCES}

1. Brittberg M, Lindahl A, Nilsson A, Ohlsson C, Isaksson O, Peterson L. Treatment of deep cartilage defects in the knee with autologous chondrocyte transplantation. $N$ Engl J Med 1994; 331(14): 889-95.

2. Gillogly SD, Voight $M$, Blackburn $T$. Treatment of articular cartilage defects of the knee with autologous chondrocyte implantation. J Orthop Sports Phys Ther 1998; 28(4): 241-51.

3. Temenoff JS, Mikos AG. Review: tissue engineering for regeneration of articular cartilage. Biomaterials 2000;21(5): 431-40.

4. O'Driscoll SW, Recklies AD, Poole AR. Chondrogenesis in periosteal explants. An organ culture model for in vitro study. J Bone Joint Surg Am 1994; 76(7): 1042-51.

5. Nakahara H, Bruder SP, Haynesworth SE, Holecek JJ, Baber MA, Goldberg VM, et al. Bone and cartilage formation in diffusion chambers by subcultured cells derived from the periosteum. Bone 1990; 11(3): 181-8.

6. Nakahara H, Bruder SP, Goldberg VM, Caplan AI. In vivo osteochondrogenic potential of cultured cells derived from the periosteum. Clin Orthop 1990(259):223-32.

7. Nakahara H, Goldberg VM, Caplan AI. Culture-expanded human periosteal-derived cells exhibit osteochondral potential in vivo. J Orthop Res 1991; 9(4): 465-76.

8. Nakahara H, Dennis JE, Bruder SP, Haynesworth SE, Lennon DP, Caplan AI. In vitro differentiation of bone and hypertrophic cartilage from periosteal-derived cells. Exp Cell Res 1991; 195(2): 492-503.

9. Nakata K, Nakahara H, Kimura T, Kojima A, Iwasaki M, Caplan AI, et al. Collagen gene expression during chondrogenesis from chick periosteum-derived cells. FEBS Lett 1992; 299(3): 278-82.

10. O'Driscoll SW. Articular cartilage regeneration using periosteum. Clin Orthop 1999(367 Suppl): S186-203.

11. Ito Y, Fitzsimmons JS, Sanyal A, Mello MA, Mukherjee N, O'Driscoll SW. Localization of chondrocyte precursors in periosteum. Osteoarthritis Cartilage 2001; 9(3):215-23.

12. Gallay SH, Miura Y, Commisso CN, Fitzsimmons JS, O'Driscoll SW. Relationship of donor site to chondrogenic potential of periosteum in vitro. J Orthop Res 1994; 12(4):515-25. 
13. O'Driscoll SW, Fitzsimmons JS. The importance of procedure specific training in harvesting periosteum for chondrogenesis. Clin Orthop 2000(380): 269-78.

14. O'Driscoll SW, Saris DB, Ito Y, Fitzimmons JS. The chondrogenic potential of periosteum decreases with age.J Orthop Res 2001; 19(1): 95-103.

15. Kuijer R, Emans PJ, Jansen E, Hulsbosch M, Surtel D, Bulstra S. Isolation and Cultivation of Chondrogenic Precursors from Aged Human Periosteum. 49th Trans ORS 2003; 28: 101.

16. Brownlow HC, Reed A, Joyner C, Simpson AH. Anatomical effects of periosteal elevation.J Orthop Res $2000 ; 18(3): 500-2$.

17. Huang Q, Goh JC, Hutmacher DW, Lee EH. In vivo mesenchymal cell recruitment by a scaffold loaded with transforming growth factor beta 1 and the potential for in situ chondrogenesis. Tissue Eng 2002; 8(3): 469-82.

18. Joyce ME, Roberts $A B$, Sporn MB, Bolander ME. Transforming growth factor-beta and the initiation of chondrogenesis and osteogenesis in the rat femur.J Cell Biol 1990;110(6):2195207.

19. Uusitalo H, Hiltunen A, Ahonen M, Kahari VM, Aro H, Vuorio E. Induction of periosteal callus formation by bone morphogenetic protein-2 employing adenovirus-mediated gene delivery. Matrix Biol 2001;20(2): 123-7.

20. Ford JL, Robinson DE, Scammell BE. The fate of soft callus chondrocytes during long bone fracture repair. J Orthop Res 2003; 21(1): 54-61.

21. Zhao Q, Eberspaecher H, Lefebvre V, De Crombrugghe B. Parallel expression of Sox 9 and Col2a1 in cells undergoing chondrogenesis. Dev Dyn 1997; 209(4): 377-86.

22. Marcus RE. The effect of low oxygen concentration on growth, glycolysis, and sulfate incorporation by articular chondrocytes in monolayer culture. Arthritis Rheum 1973;16(5):646-56.

23. Lane JM, Brighton CT, Menkowitz BJ. Anaerobic and aerobic metabolism in articular cartilage. J R heumatol 1977; 4(4):334-42.

24. Lee RB, Urban JP. Evidence for a negative Pasteur effect in articular cartilage. Biochem J 1997; 321 (Pt 1): 95-102.

25. Stevens M, Langer R, Marini R, Shastri V. The in-vivo Bioreactor: A New Approach for Bone Regeneration. 49thTrans ORS 2003; 28:0938.

26. Simon TM, Van Sickle DC, Kunishima DH, Jackson DW. Cambium cell stimulation from surgical release of the periosteum. J Orthop Res 2003;21(3): 470-80.

27. Simon T, Jackson W, Sickle DV, Kunishima D, Jackson D. Cambium Cell Stimulation repsonse to Surgical release of overlying Periosteal Tissue. 47th Trans ORS 2001; 26:0503.

28. Frayssinet P, Guichet MJ, Virion MJ. The Role of Periosteum and Bone Marrow during Rabbit Bone Regeneration. 47th Trans ORS 2001; 26:0996.

29. Eerola I, Uusitalo H, Aro H, Vuorio E. Production of cartilage collagens during metaphyseal bone healing in the mouse. Matrix Biol 1998; 17(4): 317-20.

30. Hellio Le Graverand MP, Eggerer J, Vignon E, Otterness IG, Barclay L, Hart DA. Assessment of specific mRNA levels in cartilage regions in a lapine model of osteoarthritis.J Orthop Res 2002; 20(3): 535-44.

31. Hellio Le Graverand MP, Reno C, Hart DA. Gene expression in menisci from the knees of skeletally immature and mature female rabbits. J Orthop Res 1999; 17(5): 738-44.

32. Morone MA, Boden SD, Hair G, Martin GJ, Jr., Racine M, Titus L, et al. The Marshall R. Urist Young Investigator Award. Gene expression during autograft lumbar spine fusion and the effect of bone morphogenetic protein 2. Clin Orthop 1998(351):252-65. 


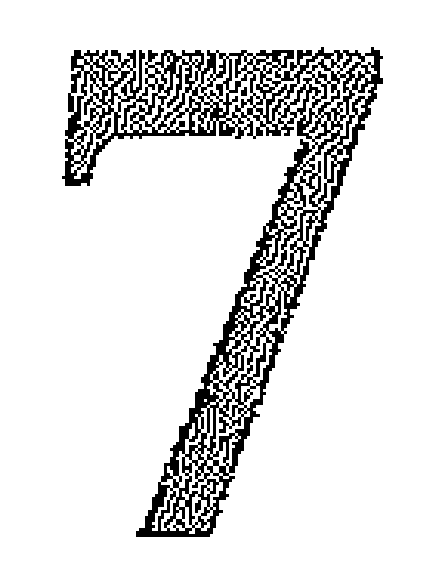
A Novel in vivo Model to study endochondral bone formation; HIF-1 $\alpha$ activation and BMP expression.

Pieter J. Emans, Frank Spaapen, Don AM. Surtel, Keryn M. Reilly, Andy Cremers, Lodewijk W. van Rhijn, Sjoerd K. Bulstra, Jan Willem Voncken ${ }^{*}$ and Roel Kuijer*. "Bone 2007 Feb; 40(2): 409-18" * Contributed equally 


\begin{abstract}
Numerous growth and transcription factors have been implicated in endochondral bone formation of the growth plate. Many of these factors are up-regulated during hypoxia and down stream of Hypoxia-Inducible Factor (HIF) $-1 \alpha$ activation. However, the specific function of these factors, in the context of oxygenation and metabolic adaptation during adult periosteal endochondral bone formation, is largely unknown. Here, we studied HIF $-1 \alpha$ and the possible roles of ( $\mathrm{HIF}-1 \alpha$ related) growth and transcription factors in a recently developed in vivo model for adult periosteal endochondral bone formation.

At different phases of periosteal endochondral bone formation, mRNA levels of Transforming Growth Factor (TGF)- $\beta_{1}$, Bone Morphogenetic Proteins (BMP)-2, -4, -7, Indian Hedgehog (Ihh), Parathyroid Hormonerelated Protein (PTHrP), Sox9, Runx2, HIF-1 $\alpha$, Vascular Endothelial Growth Factor (VEGF), periostin (POSTN), and Glyceraldehyde-3Phophate Dehydrogenase (GAPDH) were evaluated with RT-real timePCR. Also protein levels of TGF- $\beta_{1}, \mathrm{BMP}-2,-4$ and -7, HIF- $1 \alpha$ and POSTN were examined.

During the chondrogenic phase, the expression of Sox, Ihh, and HIF-1 $\alpha$ was significantly up-regulated. TGF- $\beta_{1}$ mRNA levels were rather constant, and the mRNA levels of BMPs were significantly lower. Immunohistochemical detection of corresponding gene products, however, revealed the presence of the proteins of TGF $\beta, B M P-2,-4$ and -7, HIF- $1 \alpha$ and POSTN within the chondrocytes during chondrogenesis.

This discrepancy in gene expression between mRNA and protein level for TGF $\beta 1$ and the different BMPs is indicative of post-transcriptional regulation of protein synthesis. HIF-1 $\alpha$ activation and up-regulation of GAPDH support a hypoxi-induced metabolic shift during periosteal chondrogenesis. Our model recapitulates essential steps in osteochondrogenesis and provides a new experimental system to study and ultimately control tissue regeneration in the adult organism.
\end{abstract}

\title{
INTRODUCTION
}

Endochondral bone formation is a multistage process; early commitment of mesenchymal stem cells (MSC) to a chondrogenic cell fate is accompanied by morphological changes and activation of a cartilage specific gene program. At progressive differentiation stages toward osteogenesis, chondrocytes resume proliferation, mature into hypertrophic chondrocytes, and then calcify their 
A novel in vivo model for endochondral bone formation

surrounding matrix and undergo programmed cell death ${ }^{1}$. Simultaneously, angiogenesis is stimulated and the calcified cartilage is replaced by bone.

Transforming Growth Factor (TGF)- $\beta_{1}$ and members of its superfamily, among which are the Bone Morphogenic Proteins (BMPs), play an important role in endochondral bone formation and fracture healing ${ }^{2}$. BMPs are known to interact with the Indian Hedgehog (Ihh)/Parathyroid Hormone-related Protein (PTHrP) pathway and exert their function, at least in part, via expressional regulation of Sox9, an essential transcription factor in chondrogenesis ${ }^{1-7}$.

In addition, hypoxia, as a micro-environmental determinant, is thought to promote differentiation of mesenchymal cells along a chondrocyte pathway, in part by activating Sox9 via a HIF-1alpha-dependent mechanism ${ }^{8}$. Although conditions are hypoxic within the endochondral growth plate ${ }^{9}$, not much information is available on oxygenation and metabolic adaptation during periosteal callus formation.

Several observations directly link oxygen tension to osteochondrogenic differentiation. The transcription factor Runx2 (Aml3, Osf2/Cbfa1) is required for differentiation of osteoblast progenitors during the final stages of endochondral bone formation and is also downstream of BMP signaling ${ }^{10,11}$. Runx2 mRNA is subject to IRES-dependent translational control, which is thought to permit continued translation under conditions suboptimal for capdependent translation (e.g. under low oxygen concentration) ${ }^{12}$.

The cell adhesion protein Periostin (POSTN, Osf2 - not to be confused with Osf $2 / \mathrm{Cbfa} 1$ ) is highly homologous with $\beta \mathrm{igH} 3 / \beta \mathrm{igH} 3$ and is induced by TGF$\beta_{1}$ and hypoxia ${ }^{13-16}$. POSTN may play a role in the recruitment and attachment of osteoblast precursors and is specifically found in periosteum and the periodontal ligament ${ }^{14}$. The mRNA expression for this protein is highly upregulated during fracture healing and also increases with mechanical stress in periodontal ligament tissues ${ }^{17-19}$. Most of these findings stem from in-vitro models. A possible connection between oxygenation and expression of these growth- and transcription factors during periosteal endochondral bone formation in vivo has so far not been studied.

Studies on endochondral bone formation in vivo often use whole embryos or growth plates as paradigms ${ }^{5,6,20}$. In addition, fracture healing models in adult rodents are used in which the bone marrow is penetrated ${ }^{21,22}$. To date, experimental models for endochondral bone formation in adult organisms have, to our knowledge, not been described, whereas such models are likely relevant in respect to clinical situations. We have recently established a novel in vivo model for osteochondrogenesis, in which periosteum is damaged without breaking the 
bone and accessing the bone marrow ${ }^{23}$. Periosteum contains pluripotent progenitor cells that harbor MSC characteristics ${ }^{24,25}$, and can differentiate to chondrocytes and osteoblasts during normal bone growth and fracture healing 26,27. We demonstrated the chondro-regenerative capacity of periosteal MSC ${ }^{23}$. This novel model can be used to study the function of periosteum during cartilage and endochondral bone formation. In addition, the model is expected to provide important mechanistic insight for tissue engineering of cartilage and or bone and for fracture healing ${ }^{23}$. The aim of this study was to evaluate expression of essential factors, among which the hypoxia-responsive factor HIF-1 $\alpha$, during the in vivo generation of adult periosteum derived cartilage and bone.

\section{MATERIAL AND METHODS}

\section{Surgical procedures}

Six-month-old female New Zealand White rabbits were used for this study. European and Dutch laws on animal experimentation were strictly followed throughout the study and the animal experimental protocol was approved by the Maastricht University committee for animal experiments. Surgical procedures were performed under general anesthesia and with the use of sterile techniques. Anesthetic induction was obtained with $35 \mathrm{mg} / \mathrm{kg}$ ketamine hydrochloride and $5 \mathrm{mg} / \mathrm{kg}$ xylazine hydrochloride administered by intramuscular injection. Anesthesia was maintained by means of a mixture of $2 \%$ halothane and oxygen/nitrous oxide delivered by an automatic ventilator using a specially designed mask. All rabbits received a preoperative intramuscular injection with antibiotics $(10 \mathrm{mg} / \mathrm{kg}$ ceftiofur sodium, Pharmacia \& Upjohn, Woerden, The Netherlands). Post-operative analgesia provided by administering $0,05 \mathrm{mg} / \mathrm{kg}$ buphenomorfine intramuscular once a day for 2 days.

Bilaterally, the skin and the overlying fascia were opened over the upper medial tibia. A piece of approximately $7 \times 15 \mathrm{~mm}$ of the Periosteum was dissected. The harvested tissue of five rabbits was used to assess expression levels of the genes of interest in undifferentiated periosteum $(t=0$ days). The overlying fascia was closed with Polysorb 2.0 sutures (Tyco Healthcare, USA). Special care was taken that the tendon of the semitendinosus muscle was sutured on top of the lower, short side of the rectangular periosteum defect. Hereafter the skin was closed with Polysorb 4.0 (Tyco Healthcare, USA). At day 10, 20 and 40 postoperative the reactive tissue of five rabbits per time point was harvested. For this purpose the rabbits were anaesthetized as described above. The reactive tissue was dissected with a scalpel or osteotome (40 days). Again the overlying fascia and skin were closed with Polysorb (Tyco Healthcare, USA). 
A novel in vivo model for endochondral bone formation

Specimens were cut in two halves, one part was used for RNA isolation, and the other was fixed in 4\% paraformaldehyde, dehydrated and embedded in paraffin.

\section{RNA Isolation}

Immediately after harvest, the tissue was frozen in liquid nitrogen and stored at $80^{\circ} \mathrm{C}$. The frozen tissue was cooled further in liquid nitrogen and pulverized using a microdismembrator $S$ (Bauer, Goettingen, Germany). The resulting powder was collected in TriZol reagent and RNA was extracted according to the protocol of the manufacturer (Invitrogen, Breda, The Netherlands). Quantity and purity of the RNA were determined $260 / 280 \mathrm{~nm}$ absorbance measurements. The RNA samples were subjected to RNase-free DNase digestion to remove any genomic DNA and to agarose gel electrophoresis to assess the intactness of RNA. Complete removal of genomic DNA was verified by PCR.

\section{Rabbit primer design}

Since sequence information on the rabbit genome is limited, conserved human and murine gene sequences were determined to design primer sets for Ihh, Runx2, Sox9, Collagen Type II and Type X, and POSTN by using Blast2 software (www.ncbi.nlm.nih.gov). PCR primer sets were designed for homologous gene sequences and tested on rabbit cDNA samples (Table 1). The identities of the PCR products was confirmed by direct sequencing and comparison with known human and mouse genes and then submitted to GenBank (AY633663, AY598932, AY598933, AY598934, AY598935, AY598936, AY598937).

\section{Semi quantitative Reverse Transcription-Polymerase Chain Reaction}

Although multiple real-time primer sets were tested, the expression of Collagen Type (COL) X, TGF- $\beta 1$, and thh could only determined with a semi quantitative RT-PCR. To this end, we performed PCR reactions on serially diluted cDNA's using primer sets for Ihh, TGF-B1, COLX, either alone or in combination with a primer set for 28S. $28 \mathrm{~S}$ cDNA amplification was also performed separately. Ethidiumbromide signals were quantified using a GEL-Doc 1000 system with Multi-Analyst innaging analysis (Bio-Rad, CA, USA). Marker mRNA levels are expressed relative to 28S rRNA.

Two hundred nanogram of heat denatured RNA was reverse transcribed with $100 \mathrm{U}$ MMLV reverse transcriptase (Promega, WI, USA) in $50 \mathrm{mM}$ Tris$\mathrm{HCl}\left(\mathrm{pH}\right.$ 8.3), $75 \mathrm{mM} \mathrm{KCl}$ and $3 \mathrm{mM} \mathrm{MgCl}_{2}$ and $10 \mathrm{U} \mathrm{RNAsin}$ (Promega, WI, USA). Two microliters c-DNA from each sample were amplified in $10 \mu \mathrm{L} \mathrm{PCR}$ reaction mixture. For semi-quantitative expression measurements, $200 \mathrm{ng}$ cDNA was diluted in five-fold increments (i.e. undiluted, $5 \mathrm{x}, 25 \mathrm{x}, 125,625 \mathrm{x}$ diluted). 
Chapter 7

100

Table 1: Semi quantitative RT-PCR primer sets

\begin{tabular}{|c|c|c|c|c|c|}
\hline cDNA & Size & Primer sequence & & $\begin{array}{l}\text { Genbank } \\
\text { accession }\end{array}$ & $\begin{array}{l}\text { Homology } \\
\text { with human }\end{array}$ \\
\hline COL1 & 511 & $\begin{array}{l}\text { 5'-GCACCCATGGACATTGGAGGG-3' } \\
\text { 5'-GACACGGAGTAGCACCATCG-3' }\end{array}$ & $\begin{array}{l}\mathrm{S} \\
\mathrm{AS}\end{array}$ & AY 633663 & $92 \%$ \\
\hline COLX & 329 & $\begin{array}{l}\text { 5'-ACAGGAATGCCTGTGTCTGCTTTT-3' } \\
\text { 5'-TTGGGAAGCTGGAGCCACACCTGGT-3' }\end{array}$ & $\begin{array}{l}S \\
\text { AS }\end{array}$ & AY598937 & $91 \%$ \\
\hline $\mathrm{TGF}-\beta_{1}$ & 271 & $\begin{array}{l}\text { 5'-CGGCAGCTGTACATTGACTT-3' } \\
\text { 5'-AGCGCACGATCATGTTGGAC-3' }\end{array}$ & $\begin{array}{l}\text { S } \\
\text { AS }\end{array}$ & AF000133 & $n c$ \\
\hline Sox 9 & 553 & $\begin{array}{l}\text { 5'-TGAATCTCCTGGACCCCTTC-3' } \\
\text { 5'-CCGTTCTTCACCGACTTCCT-3' }\end{array}$ & $\begin{array}{l}S \\
\text { AS }\end{array}$ & AY598935 & $96 \%$ \\
\hline Runx2 & 280 & $\begin{array}{l}\text { 5'-TGATGACACTGCCACCTGTG-3' } \\
\text { 5'-ACTCTGGCTTTGGGAAGAGC-3' }\end{array}$ & $\begin{array}{l}S \\
\text { AS }\end{array}$ & AY598934 & $99 \%$ \\
\hline POSTN & 293 & $\begin{array}{l}\text { 5'-CCACGAGGTGTCCTAGAAAGG-3' } \\
\text { 5'-TGTTTTCCAGCCAGCTCAAT-3' }\end{array}$ & $\begin{array}{l}\mathrm{S} \\
\text { AS }\end{array}$ & AY598936 & $91 \%$ \\
\hline Ihh & 318 & $\begin{array}{l}\text { 5'-TTCCAGGTCATCGAGACTCA-3' } \\
\text { 5'-CCAGAAGGCCAACTGAGC-3' }\end{array}$ & $\begin{array}{l}\mathrm{S} \\
\text { AS }\end{array}$ & AY598933 & $90 \%$ \\
\hline $\begin{array}{l}28 \mathrm{~S} \\
\mathrm{rRNA}\end{array}$ & 188 & $\begin{array}{l}\text { 5'-GGGTTTAGACCGTCGTGAGA-3' } \\
\text { 5'-GCGGGATTCTGACTTAGAGG-3' }\end{array}$ & $\begin{array}{l}\mathrm{S} \\
\mathrm{AS}\end{array}$ & AF460236 & $\mathrm{nc}$ \\
\hline
\end{tabular}

Nucleotide sequences of SQ-RT-PCR primers used for specific amplification of segments of different mRNAs. Rabbit gene sequences were submitted to the GenBank and compared to human sequences for the same gene. The rabbit sequence for TGF- $\beta_{1}$ and $28 \mathrm{~S}$ rRNA was not compared (nc) to human sequence. Abbreviations: AS, antisense; $S$, sense.

Eight microliters of each PCR sample was run on a $2 \%$ agarose gel containing $0.5 \mathrm{mg} / \mathrm{mL}$ ethidiumbromide (Invitrogen, Breda, The Netherlands). Positive bands were visualized and quantified with a Geldoc 1000 system using MultiAnalyst software (Bio-Rad, CA, USA). Values were normalized to $28 \mathrm{~S}$ rRNA expression.

Real time PCR assays

Real time PCR assays were performed in triplicates with qPCR mastermix for SYBR ${ }^{\circledR}$ Green I (Eurogentec, Seraing, Belgium) in 96-well optical plates with primer concentrations of $300 \mathrm{nM}$. Oligonucleotide sequences for Collagen Type I and II, aggrecan, BMP-2, -4 and 7, periostin, PTHrP, VEGF, 28S rRNA, GAPDH, Sox9, and HIF-1 $\alpha$ (Table 2) were based on the gene sequences which were submitted to or obtained from GenBank (Table 1) using Primer Express 2.0 software (Applied Biosystems, Foster City, CA, USA). cDNA was used for the real time quantitative PCR reactions using an ABI PRISM ${ }^{\circledR} 7700$ Sequence Detection System (Applied Biosystems, Foster City, CA, USA, user bulletin \#2). Serially diluted standard curves were included to quantify the samples. PCR conditions were: $2 \mathrm{~min}$ at $50^{\circ} \mathrm{C}, 10 \mathrm{~min}$ at $95^{\circ} \mathrm{C}, 40$ cycles for $15 \mathrm{~s}$ at $95^{\circ} \mathrm{C}$, and 1 
A novel in vivo model for endochondral bone formation

Table 2: Real time RT PCR primer sets.

\begin{tabular}{|c|c|c|c|c|}
\hline cDNA & Size & Primer sequence & & $\begin{array}{l}\text { Genbank } \\
\text { accession } \\
\end{array}$ \\
\hline COL I & 81 & $\begin{array}{l}\text { 5'-CTGACTGGAAGAGCGGAGAGTAC-3' } \\
\text { 5'-CCATGTCGCAGAAGACCTTGA-3' }\end{array}$ & $\begin{array}{l}S \\
\text { AS }\end{array}$ & AY633663 \\
\hline COL II & 84 & $\begin{array}{l}\text { 5'-TGGGTGTTCTATTTATTTATTGTCTTCCT-3' } \\
\text { 5'-GCGTTGGACTCACACCAGTTAGT-3' }\end{array}$ & $\begin{array}{l}\mathrm{S} \\
\mathrm{AS}\end{array}$ & S83370 \\
\hline BMP-2 & 76 & $\begin{array}{l}\text { 5'-AGAAAAGCGTCAAGCGAAACA-3' } \\
\text { 5'-GTCCACGTACAAAGGGTGTCTCT-3' }\end{array}$ & $\begin{array}{l}\mathrm{S} \\
\mathrm{AS}\end{array}$ & AF041421 \\
\hline BMP-4 & 66 & $\begin{array}{l}\text { 5'-ACCCGCAGCCTAGCAAGA-3' } \\
\text { 5'-CTGACTGGAGCCGGTAAAGATC-3' }\end{array}$ & $\begin{array}{l}\mathrm{S} \\
\mathrm{AS}\end{array}$ & AF042497 \\
\hline BMP-7 & 79 & $\begin{array}{l}\text { 5'-GCAACCACTGGGTGGTCAAC-3' } \\
\text { 5'-TGATGCTCTGCCCATCCA-3' }\end{array}$ & $\begin{array}{l}\mathrm{S} \\
\mathrm{AS}\end{array}$ & AF413111 \\
\hline Sox9 & 79 & $\begin{array}{l}5^{\prime} \text {-AGTACCCGCACCTGCACAAC-3' } \\
5^{\prime}-\text { CGCTTCTCGCTCTCGTTCAG }-3 \text { ' }\end{array}$ & $\begin{array}{l}\mathrm{S} \\
\mathrm{AS}\end{array}$ & AY598935 \\
\hline Runx2 & 70 & $\begin{array}{l}\text { 5'-TGATGACACTGCCACCTCTGA-3' } \\
\text { 5'-GCACCTGCCTGGCTCTTCT-3' }\end{array}$ & $\begin{array}{l}\mathrm{S} \\
\mathrm{AS}\end{array}$ & AY598934 \\
\hline POSTN & 87 & $\begin{array}{l}\text { 5'-AATACTCTCCAGTGTTCTGAGGCTATT-3' } \\
\text { 5'-CAGCTTATCTCAATTGTGTTTCCTT-3' }\end{array}$ & $\begin{array}{l}S \\
\text { AS }\end{array}$ & AY598936 \\
\hline HIF-1 $\alpha$ & 79 & $\begin{array}{l}\text { 5'-GGATATAAATTTGGCAATGCTTCCAT-3' } \\
\text { 5'-GAGTGCAGGGTCAGCACTACTTC-3' }\end{array}$ & $\begin{array}{l}\mathrm{S} \\
\mathrm{AS}\end{array}$ & AY 273790 \\
\hline VEGF & 73 & $\begin{array}{l}\text { 5'-ACGAAGTGGTGAAGTTCATGGAA-3' } \\
\text { 5'-AAGATGTCCACCAAGGTCTCGAT-3' }\end{array}$ & $\begin{array}{l}S \\
\text { AS }\end{array}$ & AY196796 \\
\hline GAPDH & 107 & $\begin{array}{l}\text { 5'-ACTTTGTGAAGCTCATTTCCTGGTA-3' } \\
\text { 5'-GTGGTTTGAGGGCTCTTACTCCTT-3' }\end{array}$ & $\begin{array}{l}\mathrm{S} \\
\mathrm{AS}\end{array}$ & L 23961 \\
\hline 28S rRNA & 73 & $\begin{array}{l}\text { 5'-GCCATGGTAATCCTGCTCAGTAC-3' } \\
\text { 5'-GCTCCTCAGCCAAGCACATAC-3' }\end{array}$ & $\begin{array}{l}\mathrm{S} \\
\mathrm{AS} \\
\end{array}$ & AF 460236 \\
\hline
\end{tabular}

Abbreviations: AS, antisense; $\mathrm{S}$, sense.

min at $60^{\circ} \mathrm{C}$ followed by a melt curve $15 \mathrm{~s}$ at $95^{\circ} \mathrm{C}$ ramp to $60^{\circ} \mathrm{C}$ for $1 \mathrm{~min}$, followed by $20 \mathrm{~s}$ at $95^{\circ} \mathrm{C}$. Data were analyzed using Sequence Detection Software version 1.7 (Applied Biosystems, Foster City, CA, USA). Values were normalized to $28 \mathrm{~S}$ rRNA.

\section{Staining protocols}

Paraffin sections were deparaffinated, hydrated and stained with thionine for 10 minutes. After washing and drying coverslips were mounted using Entellan (Merck-Europe, Darmstad, Germany).

For immuno-staining, (paraffin-embedded) sections were deparaffinated and hydrated. Primary antibodies were diluted in PBS as follows: goat-polyclonal anti-BMP-2 (Santa Cruz, CA, USA, sc-6895) 1:25; goat-polyclonal anti-BMP- 
4 (Santa Cruz, CA, USA, sc-6896) 1:12.5; goat-polyclonal anti BMP-7 1:800 (Santa Cruz, CA, USA, sc-9305); goat-polyclonal anti-TGF- $\beta_{1} 1: 30$ (R\&D Systems Inc, MN, USA); mouse-monoclonal anti-periostin 1: $600(5 \mathrm{H} 8)^{28,29}$; mouse monoclonal anti-HIF-1 $\alpha$ 1: 50 (Abcam Limited, Cambridge, UK, ab463); and mouse monoclonal anti-collagen type II (II-II6B3, diluted 1:50; Developmental Studies Hybridoma Bank, University of Iowa, Iowa City, IA).

Prior to the incubation with the goat-polyclonal anti-TGF- $\beta_{1}$, sections were placed in $250 \mathrm{~mL}$ Antigen Retrieval buffer (Dako Cytomation BV, Glostrup, Denmark) supplemented with $4.5 \mathrm{~mL} 0.1 \mathrm{M}$ citric acid + $0.5 \mathrm{~mL} 0.1 \mathrm{M} \mathrm{Na}$ citrate and incubated for 5 minutes in a microwave at $750 \mathrm{~W}$. After incubation with the primary antibody, sections where washed with PBS and incubated with an appropriate biotin-labeled secondary antibody. Subsequently, sections were washed with PBS and incubated with the avidin-biotin binding complex with Horse Radish Peroxidase (HRP) or Alkaline Phosphatase (ALP) (Dako Cytomation BV, Glostrup, Denmark). Di-aminobenzidine (DAB) (MerckEurope, Darmstad, Germany) was used as a substrate for HRP and Vectastain (Vector Laboratories, Burlingame, USA) for ALP. The sections were counterstained with hematoxylin dried and coverslipped.

\section{STATISTICAL ANALYSIS}

Differences in mRNA levels were analyzed using the Mann-Whitney $U$ test with a Hochberg post hoc correction test. Statistical significance was assigned for $\mathrm{p}<0.05$.

\section{RESULTS}

Dissection of Periosteum induced reactive tissue (periosteal callus - PC) which demonstrated cartilaginous characteristics at 10 and 20 days post-operative (PO) and osteogenic at 40 days (PO) as previously published ${ }^{23}$. To validate the new osteo/chondrogenic model, we mapped gene expression profiles during PC formation and differentiation, and compared these to published data.

Matrix and Adhesion Molecules in PC

As expected, in undamaged periosteum $(t=0)$ Collagen type II (COL2) expression was not detected. At 10 days $\mathrm{PO}$, a significant up-regulation of this marker for chondrogenesis was clearly detectable (Fig. 1A). Forty days post-surgery COL2 expression had almost returned to basal level (Fig. 1.A). A comparable 

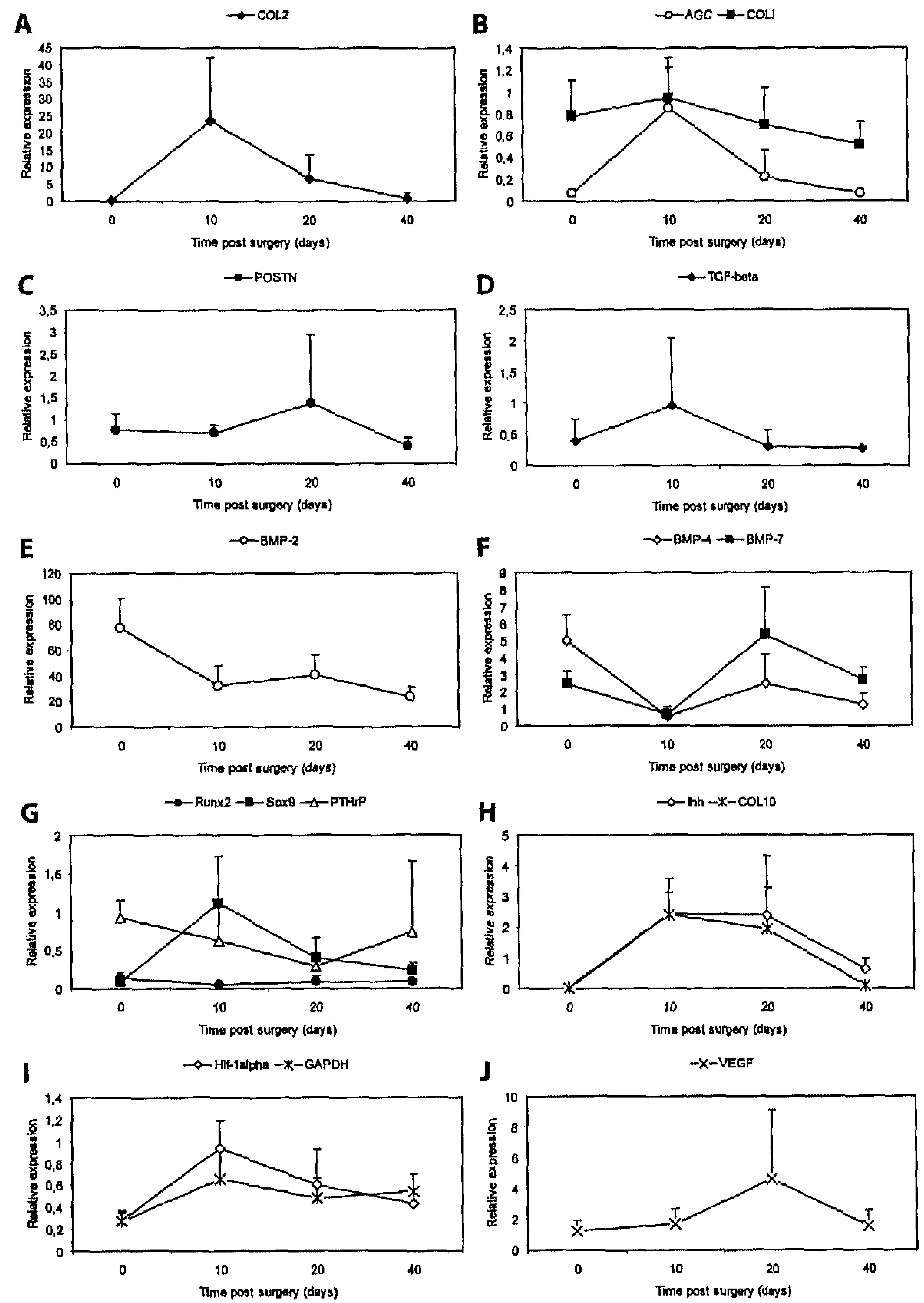

Figure 1. Gene expression profiles throughout periosteal callus formation and differentiation ( $n=5$ per time point). mRNA expression level of Collagen Type II (COL2; A), aggrecan/AGC (B), Sox9 (F), COL10 and Ihh (G), and HIF-1 $\alpha$ (I) are significantly up-regulated during periosteal chondrogenesis $(t=10)$. No significant mRNA up-or down regulation is observed for COL1 $(B)$, TGF-B 1 (C), Runx2 (F) and Periostin/POSTN (H) during follow-up. BMP-2, $-4,-7$ are significantly down regulated during chondrogenesis (D, E). VEGF expression is up-regulated 20 days post-surgery (J). Quantitative RT-PCR expression measurements are normalized to $28 \mathrm{~S}$ ribosomal RNA. Relative COL10, Ihh and TGF- $\beta_{1}$ mRNA levels were measured by semi-quantitative RT-PCR (see Materials and Methods for details). Briefly, relevant marker gene cDNAs were either separately amplified or in combination with $28 \mathrm{~S}$ rRNA. SD is indicated by error bars. 


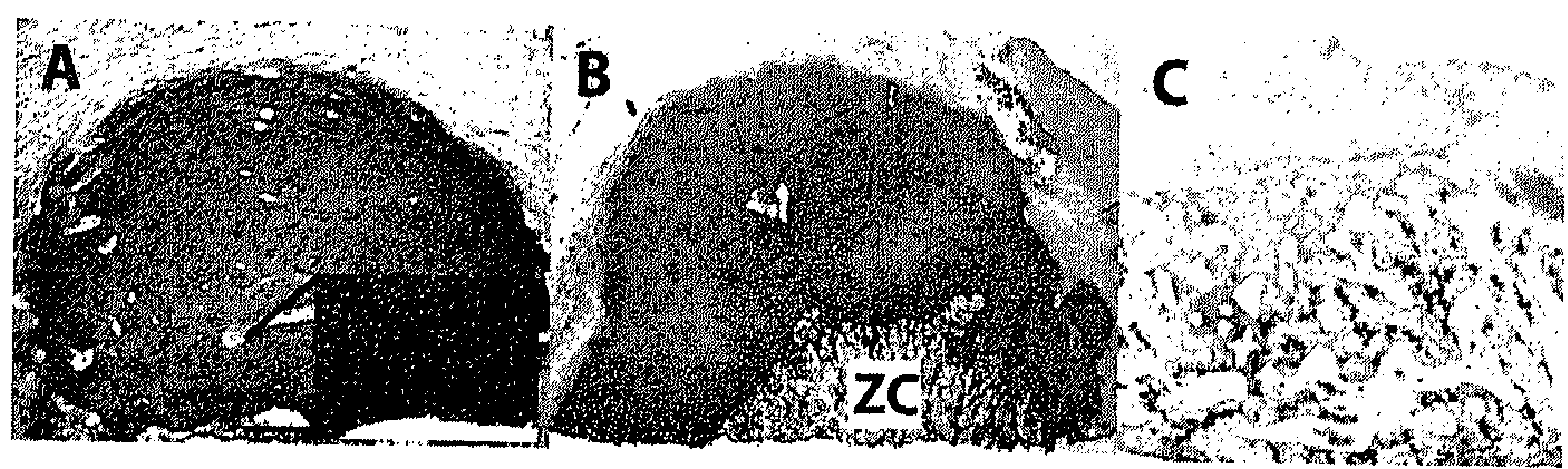

Figure 2. Immunohistochemical detection of Collagen Type II in periosteal reactive tissue (callus); (A) 10 days post-surgery this, collagen is present in the newly formed cartilage (a thionine stained section is enlarged). (B) At twenty days post-surgery the presence of Collagen Type II decreases at the zone of calcification (ZC) and bone formation. (C) 40 days post-surgery, remnants of Collagen Type II are still visible (brown). Sections counterstained with hematoxylin. Original magnification (A) X16; (B) X16; (C) X16; insert in (A) X100. See page 149 for colour figure.

expression profile was seen for aggrecan (AGC). Collagen Type I (COL1) was not significantly up-or down regulated (Fig. 1B).

Thionine staining and immunohistochemical detection of COL2 correlated nicely with mRNA expression levels: no AGC and COL2 expression was detectable in control periosteum ( $t=0$; not shown). Ten and twenty days PO, thionine staining indicated the presence of Glycosaminoglycans (GAG, i.a. AGC) and immunohistochemical detectable COL2 confirmed the expression of these proteins (Fig. 2A). Twenty days PO, ossification of the PC was first observed at the site attached to the tibial cortex (Fig. 2B). Forty days PO full ossification was observed and only remnants of cartilaginous matrix molecules were detected (Fig. 2C). mRNA levels of the adhesion molecule Periostin (POSTN) were not significantly up-or down regulated during follow-up (Fig. $1 C)$. In good agreement with this, a positive immunohistochemical staining for POSTN was observed in periosteum. This adhesion molecule was found intraand peri-cellular in both the cambium layer and the fibrous layer of periosteum $(t=0)$ (Fig. 3A). The matrix of the overlying fibrous layer remained positive during follow-up. At 10 days PO, POSTN was predominantly found in both hypertrophic and immature chondrocytes. The intensity of staining and number of POSTN positive cells was higher in chondrocytes located at the outside of the newly formed cartilage (Fig. 3C). Twenty days PO only a few of the chondrocytes stained positive for POSTN. At 40 days PO, the adhesion molecule could only be detected in some of the bone marrow cells (Fig. 3D).

\section{Growth Factors in PC}

Throughout PC formation and differentiation, relative expression of TGF- $\beta_{1}$ did not significantly change (Fig. 1D). BMP-2, -4 and -7 mRNA were down regulated $(2.4 ; 8.9 ; 3.7$ decrease respectively) during the chondrogenic phase 


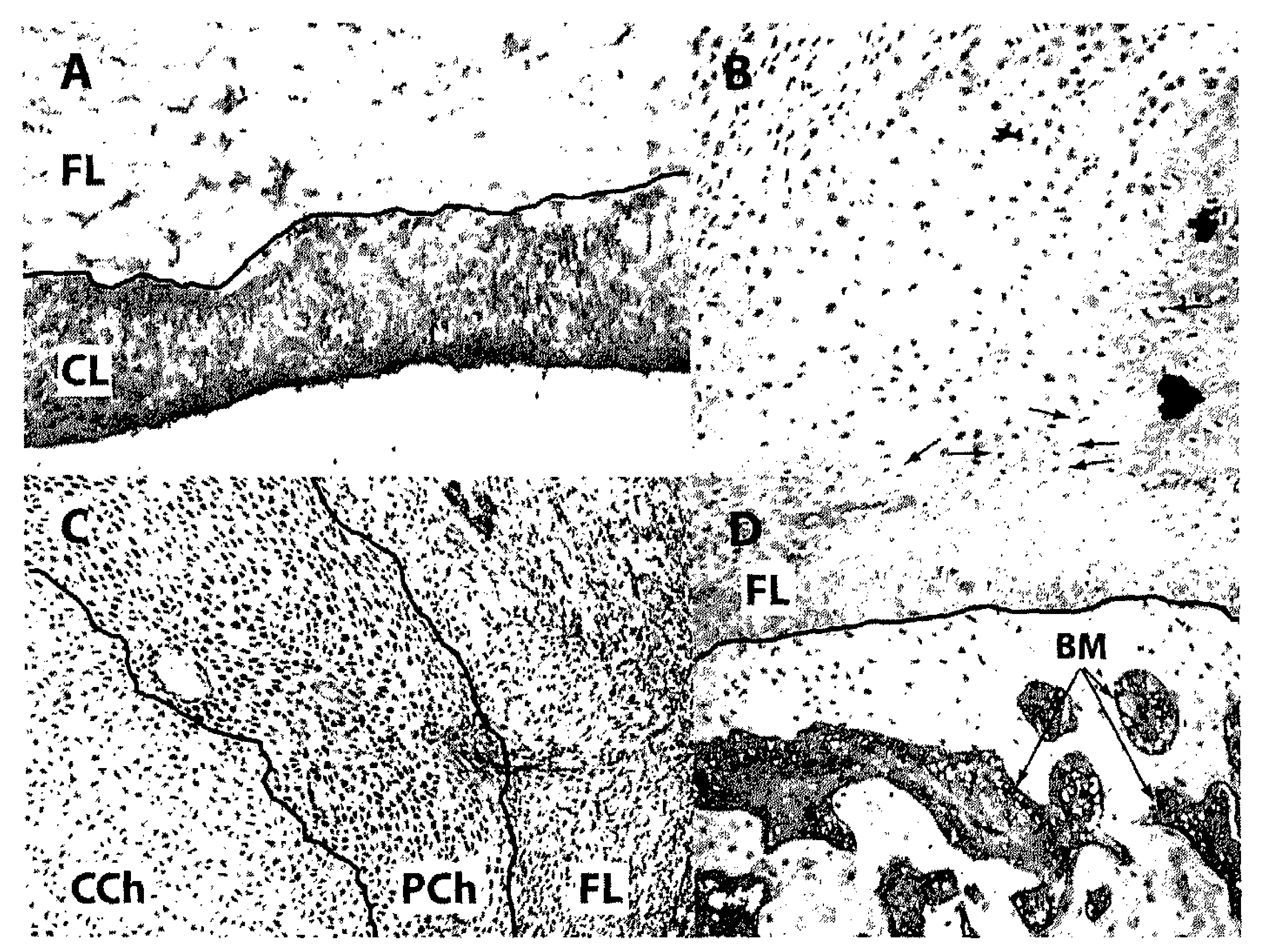

Figure 3. Immunohistochemical detection of Periostin/POSTN in periosteum. (A) POSTN is detected (brown colour) especially in the cambium layer (CL) but is also found in the fibrous layer (FL) of periosteum. (C) 10 days post-surgery the number of POSTN-positive cells is higher in the peripheral chondrocytes (PCh) compared to the chondrocytes localized centrally (CCh). (D) 40 days post-surgery, POSTN is present in the newly formed bone marrow (BM). (B) Inmunohistochemical staining of HIF $-1 \alpha$ shows its presence (red) in chondrocytes 10 days postsurgery, no HIF- $1 \alpha$ staining is found in hypertrophic chondrocytes (arrows). Original magnification (A) X200; (B) X200; (C) X200; (D) X200. See page 149 for colour figure.

(Figs. 1E, F). Immunohistochemical staining of TGF- $\beta_{1}$ confirmed protein presence in periosteum. TGF- $\beta_{1}$ was found predominantly peri-cellular in both the cambium layer and the fibrous layer of periosteum (not shown). BMP-2, -4 and -7 proteins were not detected in normal periosteum. Ten days PO, BMP-2, -4 and -7 were clearly detectable in the chondrocytes in the newly formed cartilaginous tissue; intense staining for all BMPs was specifically seen in the prehypertrophic chondrocytes. Figure 4D only shows BMP-2 staining, a similar staining was observed for BMP-2, -4 , and -7 ; however BMP-4 positive cells were detected less frequent and appeared to be more restricted to the hypertrophic zone (Figs. 4 A,B). Ten days PO, TGF- $\beta_{1}$ was also found in both hypertro- 
106

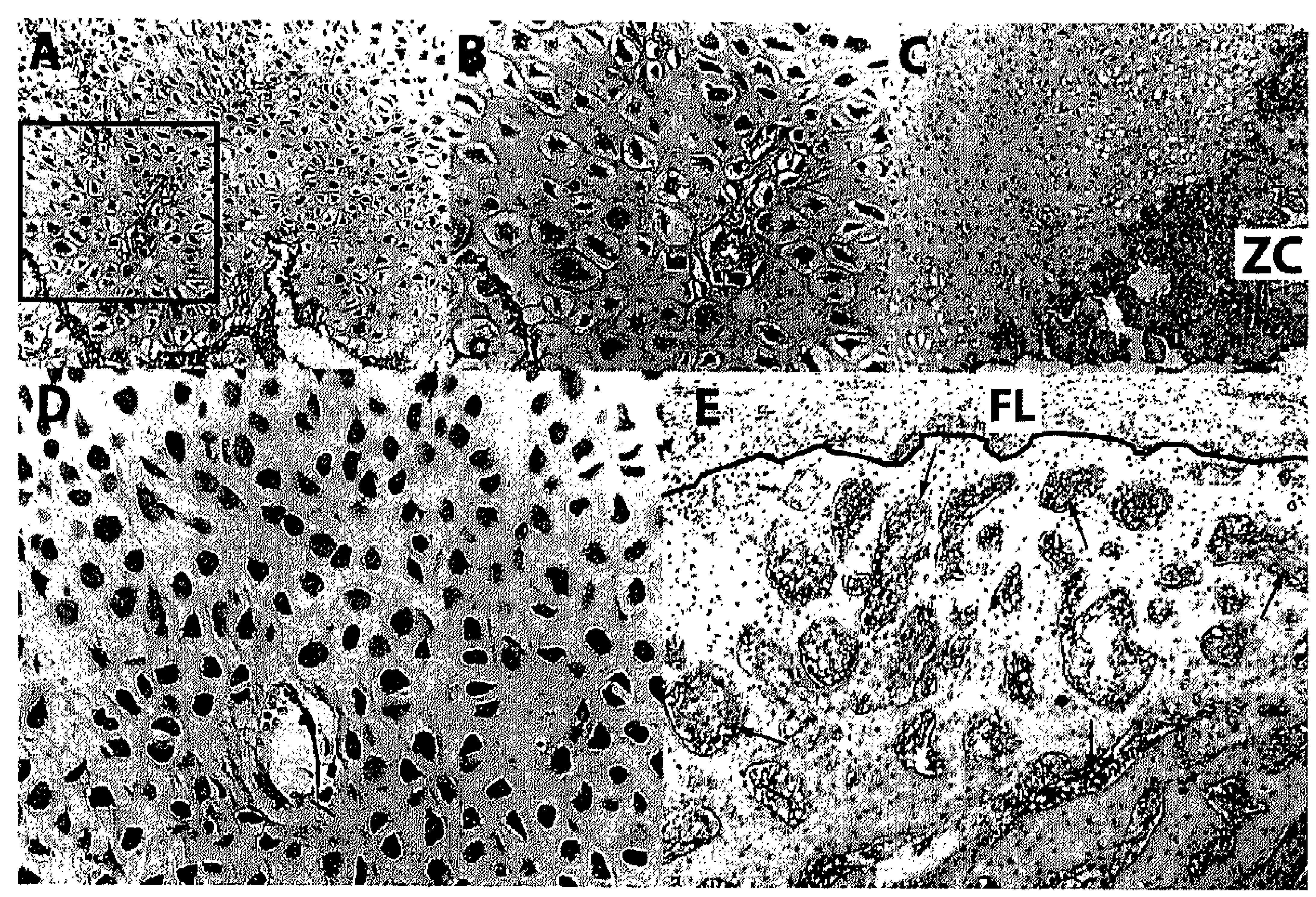

Figure 4. Immunohistochemical detection of BMP-4 in periosteal callus; (A) 10 days postsurgery, chondrocytes stain positive (red) for BMP-4. (B) is an enlargement of the box in (A). (C) 20 days post-surgery, BMP-4 is neither detected in chondrocytes nor in the zone of calcification (ZC). Sections counterstained with hematoxylin. Immunohistochemical detection of BMP-2 in periosteal callus; (D) 10 days post-surgery, chondrocytes stain positive (red) for BMP-2. (E) 40 days post-surgery, BMP-2 is detected in the newly formed bone marrow (arrows), the overlying fibrous layer is indicated with FL. Original magnification (A) X200; (B) X400; (C) X200; (D) $\mathrm{X} 400$; (E) X100. See page 150 for colour figure.

phic and mature chondrocytes and the overlying fibrous layer (not shown). Twenty days PO, BMP-2 and -4 could no longer be detected by immunohistochemical staining (Figs. 4C). The intensity of BMP-7 staining was lower; a positive staining was only found in some hypertrophic chondrocytes and some osteoblasts in the newly formed trabecular bone (not shown). At this follow-up, the staining intensity for TGF- $\beta_{1}$ also decreased and was only found in the newly formed trabecular bone.

Forty days post-surgery, the newly formed bone marrow was positive for TGF- $\beta_{1}$ and BMP-2, -4 and -7 (Fig. 4E, only BMP-2 is shown as example). Newly formed trabecular bone and bone marrow stained intensely for BMP-7; only a few cells were positive for BMP-2.

Key Lineage Specific Signaling and Programming Molecules in PC The expression of the transcription factor Sox 9 was significantly up-regulated (14 increase) at 10 days PO compared to $t=0$ (Fig. 1G). At 20 and 40 days PO 
the expression level of Sox9 gradually decreased. No significant up-or down regulation was observed for Runx2 (Fig. 1G). At 40 days post-surgery the mRNA expression level this transcription factor returned to the same level as detected in periosteum ( $t=0$; Fig. $1 G)$.

In contrast to Parathyroid Hormone-Related Protein (PTHrP) (Fig. 1G), Indian Hedgehog (Ihh) was not expressed in periosteum (Fig. 1H). During the chondrogenic phase $(t=10)$ a significant up-regulation was seen for Ihh. At all later stages during osteogenesis, mRNA levels decreased for both these genes (Figs. 1G, H).

\section{Oxygenation and Angiogenic Marker Genes}

A simultaneous increase in the mRNA expression level of GAPDH (2.6 fold increase) and a significant increase in expression level of HIF-1 $\alpha$ (3.4 fold increase) were detected at 10 days PO (Fig. 1I).

Immunohistochemical detection of HIF-1 $\alpha$ protein was reflected in the mRNA expression profile; Hif- $1 \alpha$ was only detectable in the chondrocytes present at 10 days post-surgery. Mature chondrocytes and early hypertrophic chondrocytes stained positive for HIF-1 $\alpha$. (Fig. 3B). The protein was not detected in late hypertrophic chondrocytes (Fig. 3B). At 20 days PO, a few chondrocytes in the outer layer stained positive for HIF-1 $\alpha$. In periosteum and at 40 days PO, Hif $-1 \alpha$ protein could not be detected by immunohistochemical staining. VEGF mRNA levels expression increased 20 days post-surgery (2.7 fold increase) (Fig. 1J).

\section{DISCUSSION}

We here report on a first analysis of lineage specific marker gene expression in a novel in vivo model for osteo/chondrogenesis in full-grown animals. The model makes use of experimentally induced local danage to the periosteum. The damaged periosteum responds by callus formation; within this periosteal callus (PC) MSC-like activity is mobilized, which subsequently supports and recapitulates several well-described stages of chondrogenesis and osteogenesis. During the chondrogenic phase of PC formation, we find that cells of the cambium layer first commit to a chondrogenic cell fate; mRNA of the transcription factors Sox9, Ihh, is up-regulated and cartilage matrix molecules like Aggrecan and Collagen Types II and $X$ are produced. This stage is followed by chondrocyte hypertrophy and osteogenesis as indicated by extensive calcification of surrounding matrix (to independently verify these results, we partially repeated expression analysis of matrix molecules throughout differentiation, as 
reported in one of our earlier studies ${ }^{23}$ ). Thus far, whole embryos or the growth plate are the models of choice for study of endochondral bone formation in vivo $5,6,20$. This novel concept represents a relevant pre-clinical animal model, which thus enables us to study periosteum derived endochondral bone formation in vivo in the context of physiologically relevant signaling.

Cartilage is known to lack vascularization and oxygenation probably decreases during this first step of PC formation ${ }^{9}$. In addition, because of metabolic activity and concomitant oxygen consumption, oxygen tension is expected to be low in the direct vicinity of cells ${ }^{30}$. These factors combined most likely contribute to reduced oxygen tension in our model system. The increase in mRNA expression levels of GAPDH and HIF-1 $\alpha$ and the presence of HIF- $1 \alpha$ protein are indicative of a response to a change in oxygenation, and a metabolic shift indicative of adaptation to hypoxia. Under normoxia, the HIF$1 \alpha$ subunit is rapidly degraded via a concerted action of prolyl hydroxylases, which hydroxylate Hif- $1 \alpha$, and the von Hippel-Lindau tumour suppressor gene product VHL, which ubiquitylates Hif- $1 \alpha$ and thereby targets it for proteasomal degradation. Oxygen deprivation blocks hydroxylation and thereby stabilizes Hif- $1 \alpha$. These processes play an important role in chondrocyte growth arrest and survival under hypoxia ${ }^{31,32}$. During the chondrogenic phase many essential factors are activated by HIF-1 $\alpha$ dependent mechanisms ${ }^{8,14,33-35}$. HIF- $1 \alpha$ plays an important role in the "Pasteur effect" which includes decreased oxidative phosphorylation and an increase in glycolysis ${ }^{36}$. Since glycolytic ATP-production is significantly less efficient per molecule of glucose compared to that by oxidative phosphorylation, glycolytic metabolism is up-regulated to sustain free ATP levels in the hypoxic cell. In good agreement with published data in other model systems, our PC formation model shows a concomitant increase of Hif$1 \alpha$ and GAPDH mRNA levels, one of the key-enzymes in glycolysis and a known Hif-1 $\alpha$ target ${ }^{35}$.

Interestingly, while the mRNA expression levels of BMP-2, -4 and -7 were significantly decreased during chondrogenesis, these growth factors were readily detectable by immunohistochemical staining at 10 and 40 days PO. Reports on BMP expression levels during chondrogenesis are inconsistent: Yaoita et al. report an unaffected expression of BMPs after inducing a fracture, while Kloen et al. report a positive staining of BMPs in human callus ${ }^{37,38}$. Others report a rapid up-regulation of BMP-2, only 24 hours after surgical release of the periosteum ${ }^{39}$. Uusitalo et al. reported an inducing effect on periosteal endochondral callus formation in mice upon adenovirus-mediated gene delivery of BMP-2 ${ }^{7}$. The down-regulation of BMP-2 at the RNA level we observe, is part of a genetic reprogramming controlled by autologous regulatory sequences, which may be absent in adenoviral vectors. Factors like these most 
A novel in vivo model for endochondral bone formation

likely contribute to fine-tuning of the in vivo response and further substantiate the complexity of BMP-2 regulation during chondrogenesis.

The results of the study presented herein indicate that, throughout periosteal callus formation and osteochondrogenic differentiation, BMP expression is regulated both by transcriptional and post-transcriptional mechanisms. Increased association with polysomes during conditions of cell stress (e.g. hypoxia) has recently been shown to result in preferential translation of select mRNAs ${ }^{40}$. It is tempting to speculate such mechanisms act on BMP and other mRNAs. The exact mechanism of translational regulation of cartilage matrix molecules, BMP's, Sox9, Ihh, PTHrP and periostin during chondrogenesis under conditions of lowered oxygen availability, remains unknown and are subject of further study in our laboratories.

PTHrP expression was found in periosteum. In the growth plate, this molecule diffuses to sites of hypertrophic differentiation of chondrocytes to inhibit this process ${ }^{2,41}$. Ihh was not expressed in periosteum but its expression was markedly increased during chondrogenesis at 10 days, which is an indicator of hypertrophic chondrocyte differentiation ${ }^{41}$. Combined, the presence of both Ihh and PTHrP, the sites at which they are co-expressed and the timing of their expression, are highly indicative of a function for the Ihh/PTHrP interplay in periosteal callus formation equivalent to their proposed role in growth plate models ${ }^{41}$.

In contrast to other reports ${ }^{14,19}$, in which POSTN mRNA was not detected in chondrocytes, the present study shows that POSTN protein was detectable in mature chondrocytes. POSTN is an extra cellular matrix/adhesion molecule ${ }^{16}$, however its exact function during osteo- and chondrogenesis is unclear. Our immunolocalization studies confirmed this notion, in that POSTN is also detected in the cartilaginous matrix around POSTN-positive chondrocytes. POSTN expression, both at the mRNA and protein level, is increased during fracture healing possibly to enhance the recruitment and adhesion of chondroand osteoprogenitors from essential sources such as bone marrow and blood ${ }^{19}$. The higher number of peripherally located POSTN-positive cells in the newly formed cartilage is consistent with this idea. In line with our observation that both TGF- $B$ and POSTN have similar mRNA expression profile, several studies report a TGF- $B$ dependency of POSTN regulation ${ }^{42}$. POSTN expression is regulated down-stream of cellular stress responses, including hypoxia, i.e. during vascular remodeling in different systems ${ }^{13}, 42,43$. Ectopic POSTN expression in several models increases adhesion, migration and invasiveness ${ }^{44,45}$. These properties may relate to its proposed role in epithelial-mesenchymal transition ${ }^{44}$. As a ligand for alpha- $\mathrm{V} /$ beta- 3 and alpha- $\mathrm{V} /$ beta- 5 , POSTN mediates that growth 
promoting and angiogenic signaling in experimental cancers ${ }^{46,47}$. We do not find significant upregulation of POSTN at the mRNA level, yet protein detection suggests that POSTN may be regulated in a cell type specific manner during chondrogenesis in our model. The combined above data suggest that POSTN may mediate comparable processes during chondrogenesis and endochondral bone formation. Whether regulation of POSTN includes a selective translational component, for instance in PC, awaits further analysis.

In conclusion, in our periosteal callus formation model, the sequential steps of endochondral bone development are recapitulated and we were able to describe these processes in some cellular and molecular detail: presumptive chondrocytes undergo well-ordered and controlled phases of proliferation, hypertrophic differentiation, mineralization of the surrounding matrix, and finally the cartilaginous tissue is replaced by bone. We have provided evidence that HIF- $1 \alpha$ is activated during the chondrogenic phase of periosteal callus formation, which suggests that conditions during callus formation and differentiation are, at least transiently, hypoxic. Interestingly, expression of BMP's appears to be regulated at a post-transcriptional level during these processes.

\section{Acknowledgements}

This study was supported by grant BTS00021 from Senter a ZonMw VIDI grant 016.046 .362 and by grant LLP14 of the Dutch Reumafonds. The periostin antibodies were kindly provided by Lan Bo Chen, Sasaki Hidefumi and Meiru Dai (Harvard medical school and University of Pittsburg). The mono-clonal antibodies developed by T.F. Linsenmayer et al. (II-II6B3) were obtained from the Developmental Studies Hybridoma Bank under auspices of the NICHD and maintained by the Department of Biological Sciences of the University of Iowa (Iowa City, IA). The help of May Bost, Monique de Jong, Joyce Suyk and Petra Dijkstra from the Central animal facility the animal experiments is gratefully acknowledged.

\section{REFERENCES}

1. Zhao Q, Eberspaecher H, Lefebvre V, De Crombrugghe B. Parallel expression of Sox 9 and Col2a1 in cells undergoing chondrogenesis. Dev Dyn 1997; 209(4): 377-86.

2. Yoon BS, Lyons KM. Multiple functions of BMPs in chondrogenesis. J Cell Biochem 2004 93(1): 93-103.

3. Akiyama H, Chaboissier MC, Martin JF, Schedl A, de Crombrugghe B. The transcription factor Sox9 has essential roles in successive steps of the chondrocyte differentiation pathway and is required for expression of Sox 5 and Sox6. Genes Dev 2002; 16(21):2813-28. 
A novel in viwo model for endochondral bone formation

4. Bridgewater LC, Walker MD, Miller GC, Ellison TA, Holsinger LD, Potter JL, et al. Adjacent DNA sequences modulate Sox9 transcriptional activation at paired Sox sites in three chondrocyte-specific enhancer elements. Nucleic Acids Res 2003; 31(5): 1541-53.

5. Lefebvre V, Li P, de Crombrugghe B. A new long form of Sox5 (L-Sox5), Sox6 and Sox9 are coexpressed in chondrogenesis and cooperatively activate the type II collagen gene. Embo J 1998; 17(19): 5718-33.

6. Lefebvre V, Behringer RR, de Crombrugghe B. L-Sox5, Sox6 and Sox9 control essential steps of the chondrocyte differentiation pathway. Osteoarthritis Cartilage 2001; 9 Suppl A: S69-75.

7. Uusitalo $\mathrm{H}$, Hiltunen A, Ahonen M, Kahari VM, Aro H, Vuorio E. Induction of periosteal callus formation by bone morphogenetic protein-2 employing adenovirus-mediated gene delivery. Matrix Biol 2001;20(2): 123-7.

8. Robins JC, Akeno N, Mukherjee A, Dalal RR, Aronow BJ, Koopman P, et al. Hypoxia induces chondrocyte-specific gene expression in mesenchymal cells in association with transcriptional activation of Sox9. Bone 2005; 37(3):313-22.

9. Schipani E. Hypoxia and HIF-1alpha in chondrogenesis. Semin Cell Dev Biol 2005; 16(4-5): 539 46.

10. Gersbach CA, Byers BA, Pavlath GK, Garcia AJ.Runx2/Cbfa1 stimulates transdifferentiation of primary skeletal myoblasts into a mineralizing osteoblastic phenotype. Exp Cell Res 2004; 300(2): 406-17.

11. Otto F, Thornell AP, Crompton T, Denzel A, Gilmour KC, Rosewell IR, et al. Cbfa1, a candidate gene for cleidocranial dysplasia syndrome, is essential for osteoblast differentiation and bone development. Cell 1997; 89(5): 765-71.

12. Xiao ZS, Simpson LG, Quarles LD. IRES-dependent translational control of Cbfa1/Runx2 expression.J Cell Biochem 2003; 88(3): 493-505.

13. Li P, Oparil S, Feng W, Chen YF. Hypoxia-responsive growth factors upregulate periostin and osteopontin expression via distinct signaling pathways in rat pulmonary arterial smooth muscle cells.J Appl Physiol 2004; 97(4): 1550-8; discussion 1549.

14. Horiuchi $\mathrm{K}$, Amizuka $N$, Takeshita $S$, Takamatsu $\mathrm{H}$, Katsuura $\mathrm{M}, \mathrm{Ozawa} H$, et al. Identification and characterization of a novel protein, periostin, with restricted expression to periosteum and periodontal ligament and increased expression by transforming growth factor beta.J Bone Miner Res 1999; 14(7): 1239-49.

15. LeBaron RG, Bezverkov KI, Zimber MP, Pavelec R, Skonier J, Purchio AF. Beta IG-H3, a novel secretory protein inducible by transforming growth factor-beta, is present in normal skin and promotes the adhesion and spreading of dermal fibroblasts in vitro. J Invest Dermatol 1995; 104(5): 844-9.

16. Takeshita S, Kikuno R, Tezuka K, Amann E. Osteoblast-specific factor 2: cloning of a putative bone adhesion protein with homology with the insect protein fasciclin I. Biochem J 1993; 294 (Pt 1):271-8.

17. Wilde J, Terai K, Yokozeki M, Hiura K, Horjuchi K, Kudo A, et al. Compressive mechanical stress increases periostin mRNA expression in the periochondrium.J Bone Miner Res 2000; 15:S348.

18. Wilde J, Yokozeki M, Terai K, Kudo A, Moriyama K. The divergent expression of periostin mRNA in the periodontal ligament during experimental tooth movement. Cell Tissue Res $2003 ; 312(3): 345-51$.

19. Nakazawa T, Nakajima A, Seki N, Okawa A, Kato M, Moriya $H$, et al. Gene expression of periostin in the early stage of fracture healing detected by cDNA microarray analysis. J Orthop Res 2004; 22(3): 520-5. 
20. Lefebvre V, Huang W, Harley VR, Goodfellow PN, de Crombrugghe B. SOX9 is a potent activator of the chondrocyte-specific enhancer of the pro alpha1 (II) collagen gene. Mol Cell Biol 1997; 17(4): 2336-46.

21. Einhorn TA. The science of fracture healing.J Orthop Trauma 2005; 19 (10 Suppl): S4-6.

22. Bostrom MP, Lane JM, Berberian WS, Missri AA, Tomin E, Weiland A, et al. Inmunolocalization and expression of bone morphogenetic proteins 2 and 4 in fracture healing. J Orthop Res 1995; 13(3): 357-67.

23. Emans PJ, Surtel DA, Frings EJ, Bulstra SK, Kuijer R. In vivo generation of cartilage from periosteum. Tissue Eng 2005; 11(3-4): 369-77.

24. Zohar R, Sodek J, McCulloch CA. Characterization of stromal progenitor cells enriched by flow cytometry. Blood 1997; 90(9):3471-81.

25. Ghilzon R, McCulloch CA, Zohar R. Stromal mesenchymal progenitor cells. Leuk Lymphoma 1999; 32(3-4):211-21.

26. O'Driscoll SW, Recklies AD, Poole AR. Chondrogenesis in periosteal explants. An organ culture model for in vitro study.J Bone Joint Surg Am 1994; 76(7): 1042-51.

27. Sanyal A, Sarkar G, Saris DB, Fitzsimmons JS, Bolander ME, O'Driscoll SW. Initial evidence for the involvement of bone morphogenetic protein-2 early during periosteal chondrogenesis. J Orthop Res 1999; 17(6): 926-34.

28. Sasaki H, Roberts J, Lykins D, Fujii Y, Auclair D, Chen LB. Novel chemiluminescence assay for serum periostin levels in women with preeclampsia and in normotensive pregnant women. Am J Obstet Gynecol 2002; 186(1): 103-8.

29. Sasaki H, Yu CY, Dai M, Tam C, Loda M, Auclair D, et al. Elevated serum periostin levels in patients with bone metastases from breast but not lung cancer. Breast Cancer Res Treat 2003; 77(3): 245-52.

30. Metzen E, Wolff M, Fandrey J, Jelkmann W. Pericellular PO2 and $\mathrm{O} 2$ consumption in monolayer cell cultures. Respir Physiol 1995; 100(2): 101-6.

31. Schipani E, Ryan HE, Didrickson S, Kobayashi T, Knight M, Johnson RS. Hypoxia in cartilage: HIF-1alpha is essential for chondrocyte growth arrest and survival. Genes Dev 2001; 15(21): 2865-76.

32. Lee JW, Bae SH, Jeong JW, Kim SH, Kim KW. Hypoxia-inducible factor (HIF-1)alpha: its protein stability and biological functions. Exp Mol Med 2004; 36(1): 1-12.

33. Minchenko A, Bauer T, Salceda S, Caro J. Hypoxic stimulation of vascular endothelial growth factor expression in vitro and in vivo. Lab Invest 1994; 71(3):374-9.

34. Levy NS, Chung S, Furneaux $H$, Levy AP. Hypoxic stabilization of vascular endothelial growth factor mRNA by the RNA-binding protein HuR. J Biol Chem 1998; 273(11): 6417-23.

35. Lu S, Gu X, Hoestje S, Epner DE. Identification of an additional hypoxia responsive element in the glyceraldehyde-3-phosphate dehydrogenase gene promoter. Biochim Biophys Acta $2002 ; 1574(2): 152-6$.

36. Seagroves TN, Ryan HE, Lu H, Wouters BG, Knapp M, Thibault P, ct al. Transcription factor HIF-1 is a necessary mediator of the pasteur effect in mammalian cells. Mol Cell Biol 2001; $21(10): 3436-44$.

37. Yaoita $\mathrm{H}$, Orimo $\mathrm{H}$, Shirai $\mathrm{Y}$, Shimada T. Expression of bone morphogenetic proteins and rat distal-less homolog genes following rat femoral fracture. J Bone Miner Metab 2000; 18(2): 63-70.

38. Kloen P, Di Paola M, Borens O, Richmond J, Perino G, Helfet DL, et al. BMP signaling components are expressed in human fracture callus. Bone $2003 ; 33(3): 362-71$.

39. Simon TM, Van Sickle DC, Kunishima DH, Jackson DW. Cambium cell stimulation from surgical release of the periosteum. J Orthop Res 2003;21(3): 470-80. 
A novel in vivo model for endochondral bone formation

40. Koritzinsky M, Magagnin MG, van den Beucken T, Seigneuric R, Savelkouls K, Dostie J, et al. Gene expression during acute and prolonged hypoxia is regulated by distinct mechanisms of translational control. Embo J 2006; 25(5): 1114-25.

41. Kronenberg HM, Chung U. The parathyroid hormone-related protein and Indian hedgehog feedback loop in the growth plate. Novartis Found Symp 2001;232:144-52; discussion 152-

42. Chen YF, Feng JA, Li P, Xing D, Ambalavanan N, Oparil S. Atrial natriuretic peptidedependent modulation of hypoxia-induced pulmonary vascular remodeling. Life Sci 2006.

43. Li G, Oparil S, Sanders JM, Zhang L, Dai M, Chen LB, et al. Phosphatidylinositol-3-kinase signaling mediates vascular smooth muscle cell expression of periostin in vivo and in vitro.
Atherosclerosis 2005 .

44. Yan W, Shao R. Transduction of a mesenchyme-specific gene periostin into $293 \mathrm{~T}$ cells induces cell invasive activity through epithelial-mesenchymal transformation. J Biol Chem
2006.

45. Kii I, Amizuka N, Minqi L, Kitajima S, Saga Y, Kudo A. Periostin is an extracellular matrix protein required for eruption of incisors in mice. Biochem Biophys Res Commun 2006;
$342(3)$ : 766-72.

46. Shao R, Bao S, Bai X, Blanchette C, Anderson RM, Dang T, et al. Acquired expression of periostin by human breast cancers promotes tumor angiogenesis through up-regulation of vascular endothelial growth factor receptor 2 expression. Mol Cell Biol 2004; 24(9):3992-
4003 .

47. Gillan L, Matei D, Fishman DA, Gerbin CS, Karlan BY, Chang DD. Periostin secreted by epithelial ovarian carcinoma is a ligand for alpha(V)beta(3) and alpha(V)beta(5) integrins and promotes cell motility. Cancer Res 2002; 62(18): 5358-64. 


\section{Repair of osteochondral defects in rabbits with ectopically produced cartilage}

Emans P.J., Hulsbosch M, Wetzels G.M.R., Bulstra S.K., Kuijer R.

Tissue Engineering. 2005 Nov-Dec;11(11-12):1789-96. 


\section{ABSTRACT}

Cartilage has a poor regenerative capacity. Donor site morbidity and interference with joint homeostasis should be considered when applying the autologous chondrocyte transplantation technique. The use of ectopically produced cartilage, derived from periosteum might be a novel method to heal cartilage defects.

Ectopic cartilage was produced by dissecting a piece of periosteum from the tibia of rabbits. After 14 days the reactive tissue at the dissection site was harvested and a graft was cored out and press-fit implanted in an osteochondral defect in the medial condyle of the femur with or without addition of hyaluronan. After 3 weeks and 3 months the repair reaction was evaluated by histology. Thionine- and collagen type II-stained sections were evaluated for graft viability, ingrowth of the graft, and joint surface repair.

Empty defects remained empty 3 weeks after implantation, ectopic cartilage filled the defect to the level of the surrounding cartilage. Histologically, the grafts were viable, consisting mainly of cartilage, and showed a variable pattern of ingrowth. Three months after implantation empty defects with or without hyaluronan were primarily filled with fibrocartilaginous tissue. Defects treated with ectopic cartilage contained mixtures of fibrocartilaginous and hyaline cartilage. Sometimes a tidemark was observed in the new articular cartilage and the orientation of the cells resembled that of healthy articular cartilage. Subchondral bone repair was excellent. The modified O'Driscoll scores for empty defects without and with hyaluronan were 12.7 \pm 6.4 and $15.3 \pm 3.2$; for treated defects scores were better $(15.4 \pm 3.9$ and18.2 \pm 2.9 ).

In this conceptual study ectopic cartilage derived from periosteum appeared to be a promising novel method for joint surface repair in rabbits.

\section{INTRODUCTION}

Articular cartilage has a limited capacity for repair. Injured articular surfaces are generally thought to progress toward premature osteoarthritis $(\mathrm{OA})^{1}$. Osteoarthritis is an invalidating disease that hampers daily life activities and is a substantial burden for health care burden.

Research has been focused on repair of articular surfaces by Tissue-Engineering methods. Various treatment modalities are currently available, such as autologous perichondrium transplantation ${ }^{2-5}$, debridement combined with microfracture or subchondral drilling ${ }^{6-8}$, Mosaic Plasty, ${ }^{9},{ }^{10}$ and Autologous Chondrocyte Transplantation (ACT) ${ }^{11}$. All these methods have their drawbacks: 
fixation of the graft was a major problem in perichondrium transplantations ${ }^{12}$; this has been resolved by changes in the operation technique (S.K. Bulstra, unpublished data). Microfracture or subchondral drilling procedures have been shown to produce repair tissue that is fibrocartilaginous, although significant symptomatic relief has been obtained. Mosaicplasty requires harvesting of osteochondral plugs from less weight-bearing sites of the affected joint, and the fate of the donor sites is unclear. There are experimental indications that damaged cartilage, also in less weight-bearing sites, will result in $\mathrm{OA}^{13}$. ACT also requires harvesting of cartilage from a less weight-bearing site of the affected joint. Other drawbacks of the latter procedure are the costs and safety requirements of the cell culture procedure that is part of this method. In a randomized trial comparing ACT with the microfracture technique, no clinical differences were found at 2 years of follow-up ${ }^{14}$.

Hyaluronan (HYA) is known to be chondroprotective, to prevent apoptosis via the CD44 receptor, and has even been reported to enhance cartilage repair ${ }^{15}$. Therefore HYA may contribute to cartilage repair techniques as mentioned above ${ }^{15}$.

We discovered that under certain conditions, dissecting a piece of periosteum from the proximal tibia resulted in the formation of ectopic cartilage, which in time gradually transformed into bone ${ }^{16}$. The ectopic cartilage contained collagen type II fibers and the expressions of collagen type II and aggrecan genes were up-regulated at 10 and 20 days postinduction. Collagen type I was present at 10 days, but could no longer be detected at 20 days postinduction in the cartilaginous tissue ${ }^{16}$. A similar form of periosteum-derived cartilage tissue engineering has previously been described by Stevens $e t a^{17}$.

In the present study we induced ectopic cartilage in rabbits and transplanted the tissue 14 days after induction in osteochondral defects in the same animals (autologous procedure) with or without additional hyaluronan ${ }^{15,18-21}$. Graft ingrowth and viability were examined at 3 weeks. Repair of the joint surface was evaluated at 3 months postimplantation.

\section{MATERIAL AND METHODS}

\section{Surgical procedures}

Six-month-old female New Zealand White rabbits were used for this study. European and Dutch laws on animal experimentation were strictly followed throughout the study and the experimental animal protocol was approved by the Maastricht University committee for animal experiments. Surgical procedures were performed under general anesthesia and using strictly aseptic techniques. Anesthetic induction was obtained with ketanine hydrochloride (35 
$\mathrm{mg} / \mathrm{kg}$ ) and xylazine hydrochloride $(5 \mathrm{mg} / \mathrm{kg}$ ) administered by intramuscular injection. Anesthesia was maintained by means of a mixture of $2 \%$ isoflurane and oxygen delivered by an automatic ventilator using a specially designed mask. Preoperatively all rabbits received an intramuscular injection with antibiotics (ceftiofur sodium, $10 \mathrm{mg} / \mathrm{kg}$ : Pharmacia \& Upjohn, Woerden, The Netherlands). Postoperative painkilling was done by administering buphenomorfine $(0.05 \mathrm{mg} / \mathrm{kg})$ intramuscularly per day for 2 days. Both legs of the rabbits were operated.

The skin was opened at the medial side of the knee and upper medial side of the tibia. The knee joint was opened medially; an incision of the patellar tendon was made its length. A cartilage-only defect, $3 \mathrm{~mm}$ diameter, was made on the medial condyle, using a sharp dermal biopsy punch. The rationale for this is that the animal model more resembles the clinical situation, in which patients with isolated articular cartilage defects are operated weeks to months after the trauma causing the defect has occurred ${ }^{12}$. The model will be described elsewhere ${ }^{22}$. The knee was closed with Polysorb 2.0 (Tyco Healthcare/U.S. Surgical, Norwalk, CT).

Hereafter an incision perpendicular on the fascia of the pes anserinus was made in order to access the underlying periosteum. A periosteal defect of approximately $6 \times 12 \mathrm{~mm}$ was created. The fascia and the pes ancerinus were sutured with Polysorb 2.0. With special care, the tendon of the semitendinosus muscle was sutured on top of the distal, short side of the periosteal defect. Hereafter the skin was closed with Polysorb 4.0 (Tyco Healthcare, USA). Fourteen days after the first operation, the rabbits were anesthetized and the knee was accessed as described above. The reactive tissue, Cartilage-Out-of Periosteum (COP), was dissected with a scalpel. A construct with a diameter of $3 \mathrm{~mm}$ was cored out with a sharp dermal biopsy punch (Figure 1A). The overlying fibrous tissue was dissected from the construct and the thickness of the construct was measured. The cartilage defect on the medial condyle was extended to an osteochondral defect of the same depth as the thickness of the construct, using a bore with a diameter of $3 \mathrm{~mm}$. The constructs were press-fit implanted (Figure 1B) Osteochondral defects were treated as follows: (1) left empty (empty group), (2) the defect received a drop of Hyaluronan (HYA) (Ostenil, Chemedica, Munich, Germany) and after closure the knee was injected with $1 \mathrm{~mL}$ HYA (empty plus HYA group), (3) press-fit filled with ectopic cartilage (EC group), or (4) treated with a drop of HYA in which the ectopic cartilage was press-fit implanted and after closure the joint was injected with $1 \mathrm{~mL}$ of HYA in the (EC plus HYA group). Again the overlying fascias, joint and skin were closed with Polysorb sutures (Tyco Healthcare/U.S. Surgical). After 3 weeks and 3 months the rabbits were killed by cervical dislocation or with an overdose of 


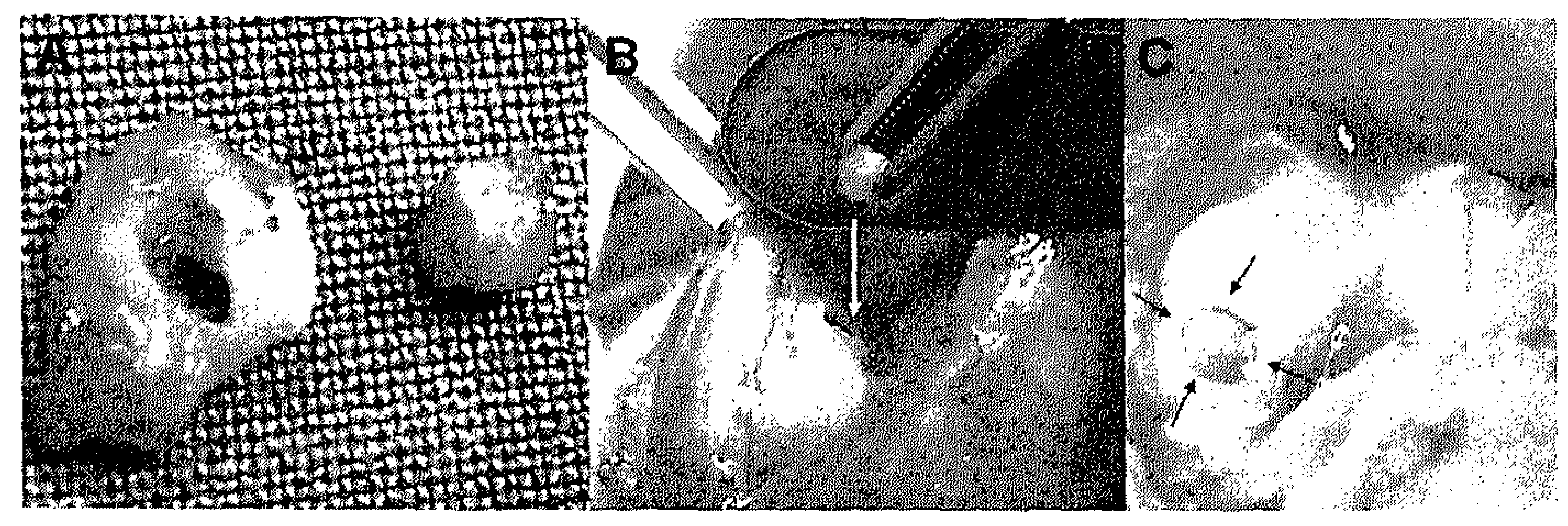

Figure 1: (A) Graft (diameter, $3 \mathrm{~mm}$ ) cored out of periosteum-derived ectopic cartilage. (B) The graft is pres- fit implanted in an osteochondral defect in the medial condyle of a rabbit. The defect diameter was $3 \mathrm{~mm}$ and the same depth as the thickness of the graft. (C) View of a graft implanted in the osteochondral defect (arrows).

pentobarbital. The femoral condyles were harvested and fixed in $4 \%$ paraformaldehyde.

\section{Staining protocols}

After decalcification in EDTA the condyles were dissected in two pieces and dehydrated in a series of increasing concentrations of ethanol. Half were embedded in glycidyl methacrylate (GMA) (Technovit 7100; Heraeus Kulzer, Wehrheim, Germany), and the other half were embedded in paraffin. Fivemicrometer sections were cut, and the GMA sections were stained with thionine or Haematoxilin \& Eosin (H\&E). Cell and nucleus morphology were judged by an experienced pathobiologist in order to determine cell and tissue viability (subjective and qualitative). The modified O'Driscoll score (naximum score, 27$)^{23}$ for cartilage repair was used to evaluate the quality of cartilage repair ${ }^{24-26}$. Two observers blinded for the sample codes scored the sections independently. Since the differences between empty defects and treated defects were obvious, the observers were only blinded for the addition of HYA. Also, the extent of subchondral bone repair was scored as level, incomplete, or protruding.

For immunohistochemical staining of collagen type II, sections were dewaxed and hydrated to standard protocols. Then the sections were pretreated with $1 \%$ hyaluronidase $\left(30 \mathrm{~min} 37^{\circ} \mathrm{C}\right.$ ) and $0,2 \%$ pronase $\left(30 \mathrm{~min} 37^{\circ} \mathrm{C}\right)$ and a 1:50 dilution of the primary antibody solution (mouse monoclonal anticollagen type II, II-II6B3; Developmental Studies Hybridoma Bank [DSHB], Iowa City, IA) was applied. After overnight incubation with the primary antibody at room temperature, sections were washed with phosphate-buffered saline (PBS) and incubated with the secondary antibody, horseradisch peroxidase (HRP)-conjugated rabbit anti-mouse IgG (ITK Diagnostics, Uithoorn, The 
Chapter is

120

Netherlands). Subsequently, sections were washed with PBS and incubated with the avidin-biotin complex conjugated with HRP. Diaminobenzidine (DAB) was used as a substrate for peroxidase.

The sections were counterstained with hematoxylin and dried, and coverslips were applied.

\section{STATISTICAL ANALYSES}

The Mann-Whitney $U$ test with a Hochberg post hoc correction test was used for statistical analysis of the modified O'Driscoll scores. The significance level was set at $\mathrm{P}<0.05$. The Chi-square test at $\mathrm{p}<0.05$ was used to analyse the level of subchondral bone repair.

\section{RESULTS}

Observations and Macroscopic impression

At the second operation ectopic cartilage production was found in $93 \%$ of the cases by macroscopical and histological examination (see also Emans et a $1^{16}$ ). The average thickness of the generated constructs was $2.05 \pm 0.39 \mathrm{~mm}(\mathrm{n}=38)$.

During the first week after the second operation, it was observed that the rabbits limped, favoring the leg in which the defect was left empty. This was not observed if the defect was treated with COP.

Macroscopic examination revealed that after 3 weeks the empty defects, both with $(n=4)$ and without $(n=5)$ HYA, were far from completely filled (Figure $2 \mathrm{~A})$. In contrast, at this time all defects treated with an ectopic cartilage graft both with $(n=7)$ and without $(n=8)$ HYA were filled to the level of the surrounding cartilage (Figure $2 \mathrm{~B}$ ).

After 3 months two of the empty osteochondral defects were still not filled completely. At this time none of the osteochondral defects treated with ectopic cartilage grafts (with HYA $(n=10)$ or without HYA $(n=8)$ ) showed gross defects.

\section{Histology and Cartilage repair score}

After 3 weeks, some fibrin formation, fibroblasts and macrophages were observed in the empty defects both with and without HYA (Figures 3A and C). The first signs of a primary osteogenic repair reaction were visible. The implanted grafts had a viable appearance, consisted mainly of cartilage, and showed a good ingrowth in the majority of the cases (Figures 3B and D).

After 3 months follow-up the empty defects were partially filled with a fibrous or fibro-cartilaginous tissue (Figure 4A). The modified O'Driscoll 


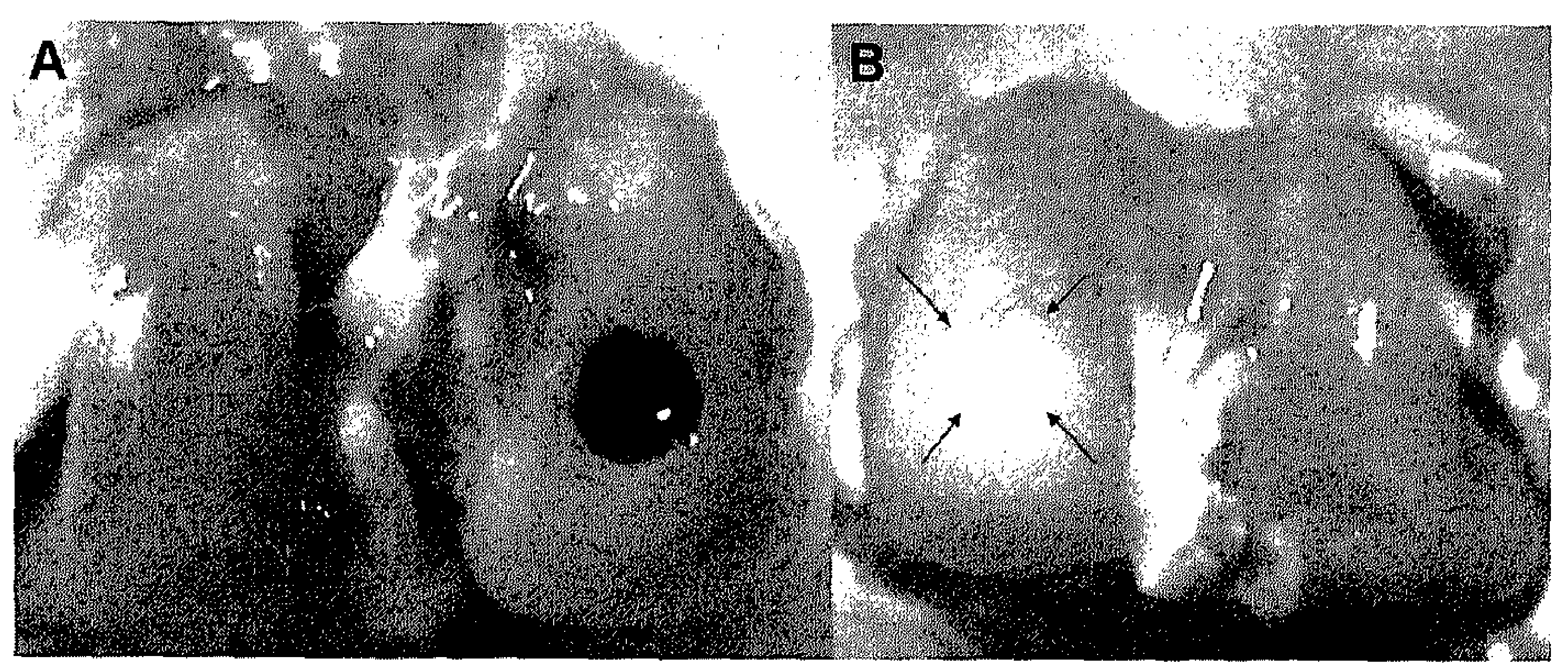

Figure 2: (A) Macroscopical view at follow-up wcek 3 of an empty osteochondral defect. (B) Macroscopical view at follow-up week 3 of an osteochondral defect treated with an ectopic cartilage graft (arrows). The defect is filled up to the level of the surrounding tissue.

scores for the groups of empty defects without and with HYA were $12.7 \pm 6.4$ and $15.3 \pm 3.2$, respectively. Defects treated with ectopic cartilage grafts revealed restoration with fibro-cartilaginous tissue up to repair with hyaline cartilage and good integration with the existing cartilage (Figure 4B). Pathologically, the repair tissues in all treated defects were completely viable. In some cases the new articular cartilage appeared to have a tidemark and the orientation of the cells was similar as in healthy articular cartilage (Fig 4C and D). The cells were rounded in the radial and deep zones of the cartilage and flattened at the superficial layer. The number of cells was higher than in the adjacent recipient cartilage. The modified O'Driscoll scores for the groups treated with ectopic cartilage grafts without and with HYA were $15.4 \pm 3.9$ and $18.2 \pm 2.9$, respectively. The differences between the two groups with empty defects, with or without HYA, and the group with treated defects plus HYA were significant, $p<0.02$ (Figure $5)$. HYA alone did not significantly enhance cartilage repair compared to the empty control.

Remarkable was the good subchondral bone repair in almost all cases. In four cases bone growth was protruding into areas where normally articular cartilage would be present: two empty defects, one empty plus HYA defect, and one treated plus HYA defect (Figure 6). There was no significant difference in subchondral bone repair between the empty defects and the ectopic cartilagetreated defects. However, there was a significant difference between defects treated with HYA and not treated with HYA: with HYA in $61.1 \%(11 / 18)$ of the defects the subchondral bone was scored as level, without HYA this was $45.5 \%(5 / 11)(\mathrm{p}<0,01)$. 

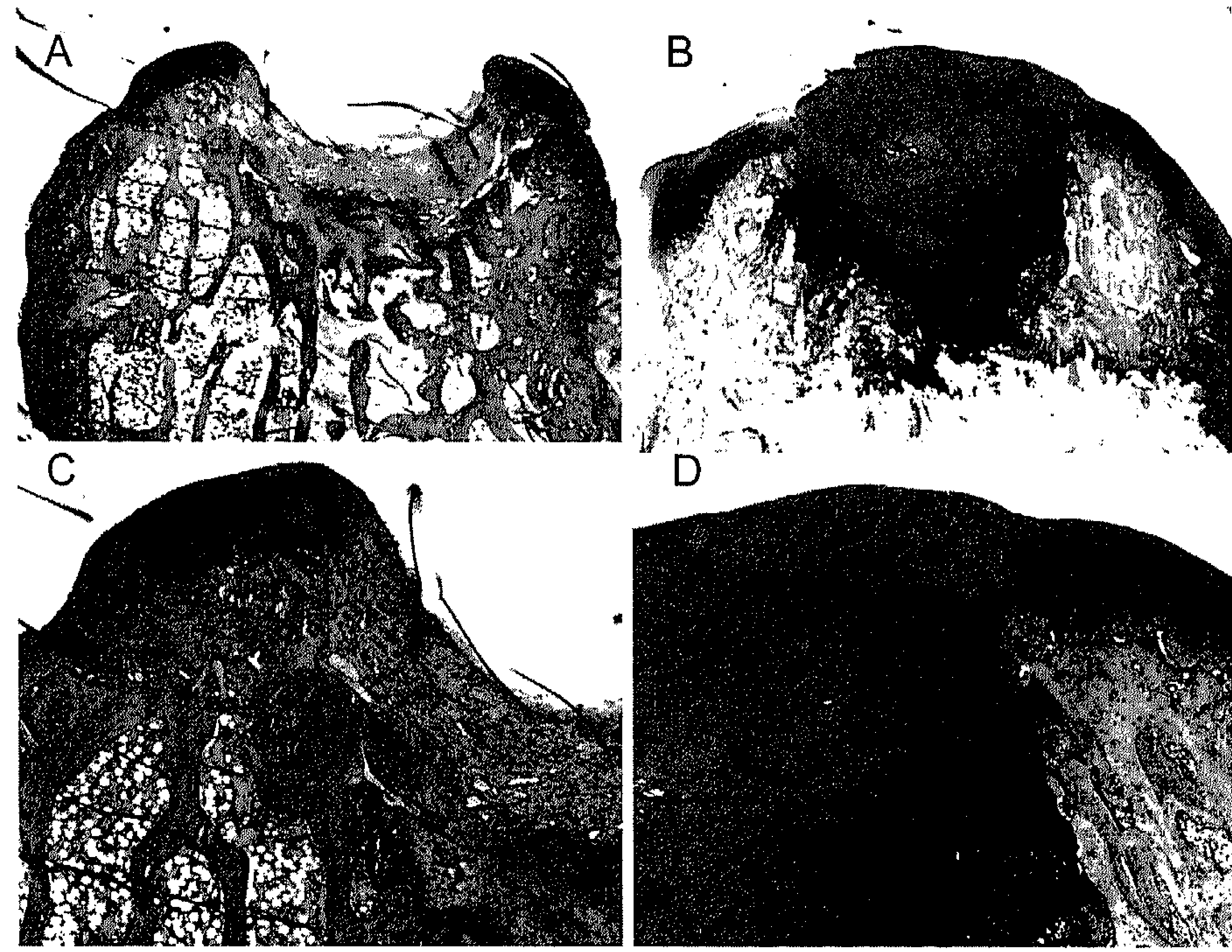

\section{D}

$\mathrm{E}$
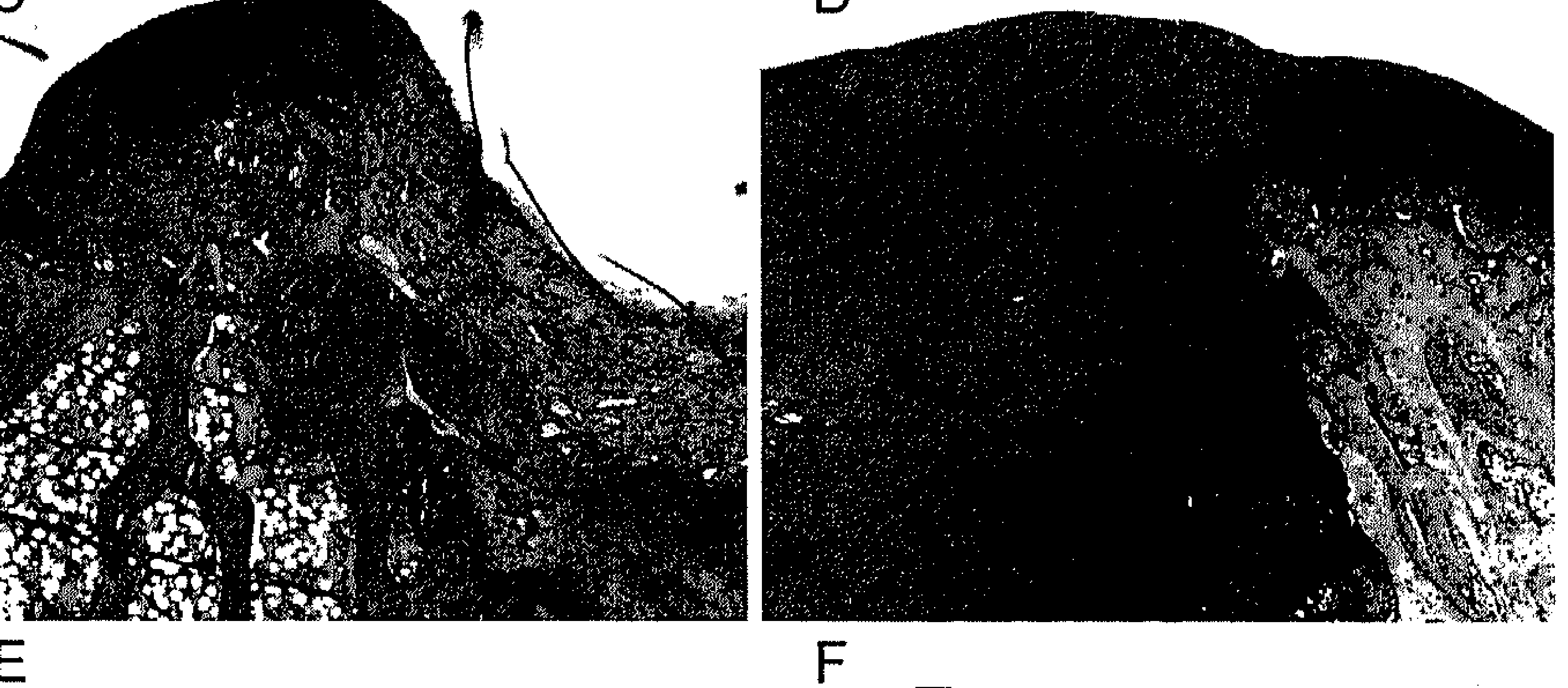

\section{$\mathrm{F}$}

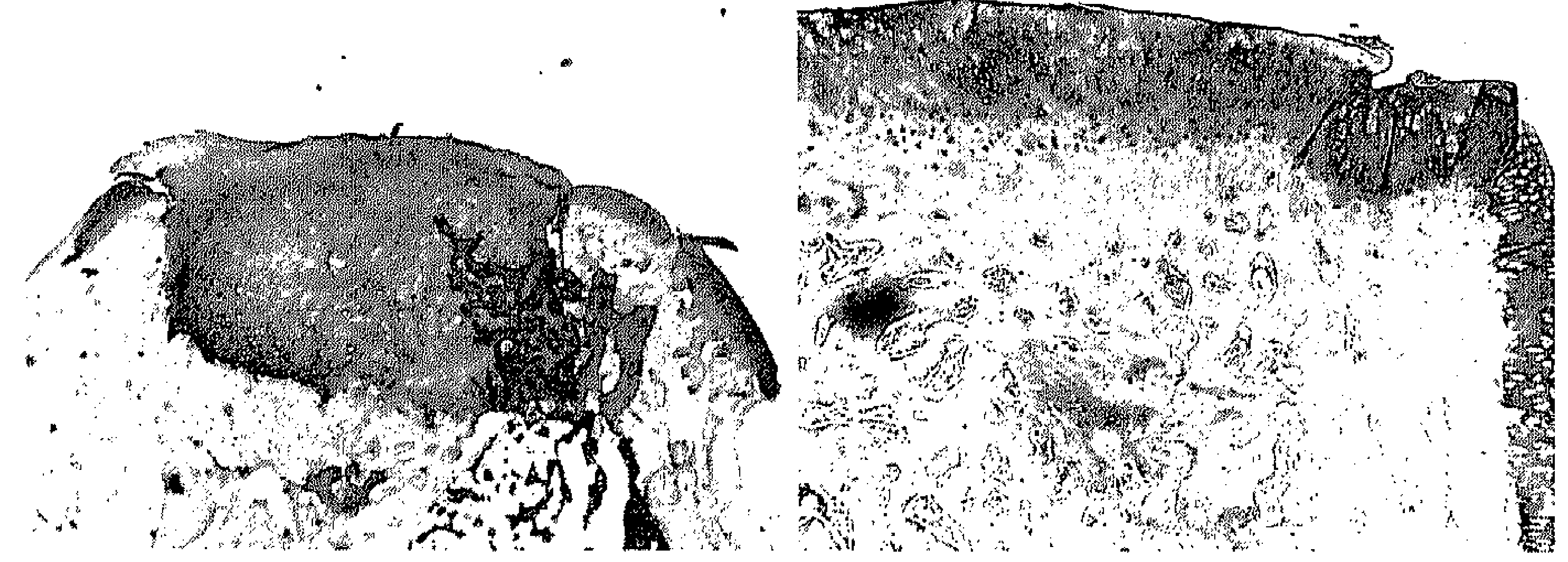

Figure 3: (A) Thionine staining of an empty osteochondral defect at 3 weeks, treated with HYA. (B) Thionine staining of an osteochondral defect in which ectopic cartilage (no HYA) has been implanted. The joint surface level was restored, the graft appeared viable, and good tissue ingrowth was obscrved. (C) Enlargement of (A) showing the initial repair with fibrous tissue with some macrophages. (D) Enlargement of (B) showing a proper integration of the graft and the original tissue. (E) Section of a grafted defect with HYA at 3 weeks, stained with a Collagen Type II antibody. (F) Section of a grafted defect at 3 months, stained with a Collagen Type II antibody. Original magnification: (A, B, and E) X 16; (C and D) X 50; (F) X 40. See page 151 for colour figure. 

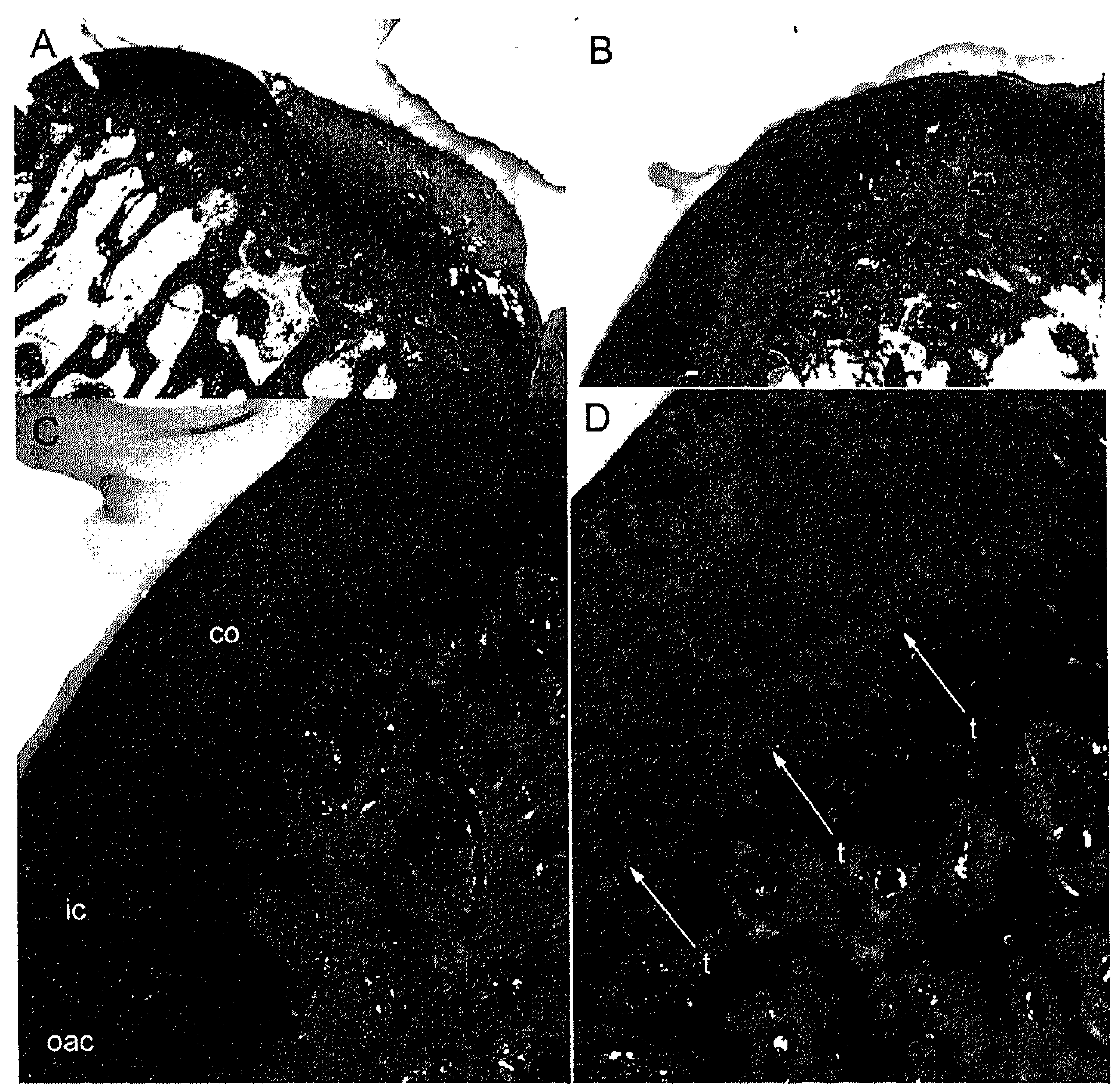

Figure 4: (A) Section of an empty defect plus HYA at 3 months, stained with thionine. The defect was partially filled with fibrous tissue. (B) Section of a grafted defect plus HYA at 3 months, stained with thionine. Good ingrowth in the adjacent cartilage was observed. The newly formed subchondral bone protrudes slightly. (C) Higher magnification of (B), illustrating a "hyalin cartilage-like' orientation of the chondrocytes ( $\mathrm{Co}$ ). The implanted cartilage (ic) shows a good ingrowth in the original articular cartilage (oac); (D) Higher magnification of (B), illustrating the presence of a tidemark ( $t$ ), indicated with arrows. Original magnification: (A and B) X 16; (C) X 100; (D) X 200. See page 152 for colour figure.

\section{Immunohistochemical staining}

Three weeks after implantation the graft remained positive for collagen type II (Fig. 3E). Some collagen type II was visible at the bottom of the empty defect. Three months after transplantation collagen type II staining was seen in all osteochondral defects treated with ectopic cartilage (Fig. 3F). The repair tissue formed if the defect was left empty also showed a positive collagen type II staining in most cases. Overall, no large differences in collagen type II staining could be detected between the empty and treated groups. 


\section{Chapter is}

124

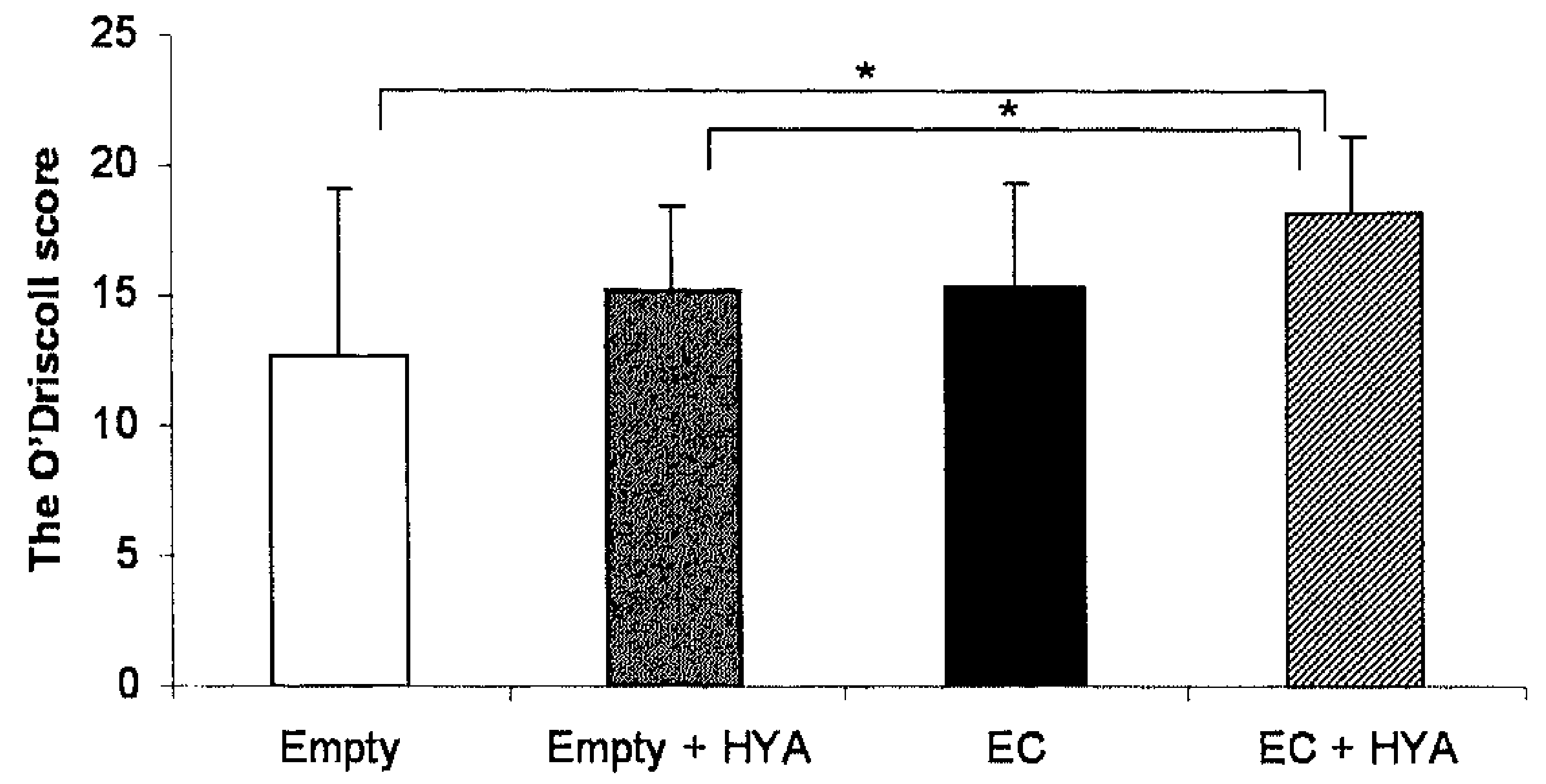

Figure 5: Modified O'Driscoll scores, after 3 months follow-up, for of empty defects groups treated without or with HYA were $12.7 \pm 6.4$ and $15.3 \pm 3.2$ respectively. The scores were $15.4 \pm$ 3.9 and $18.2 \pm 2.9$, respectively, for groups treated with ectopic cartilage $(\mathrm{ec})$ grafts without and with HYA. Differences between the two empty defects groups, with or without HYA, and the treated defects group plus HYA, were significant $\left({ }^{\star} \mathrm{p}<0.02\right)$.

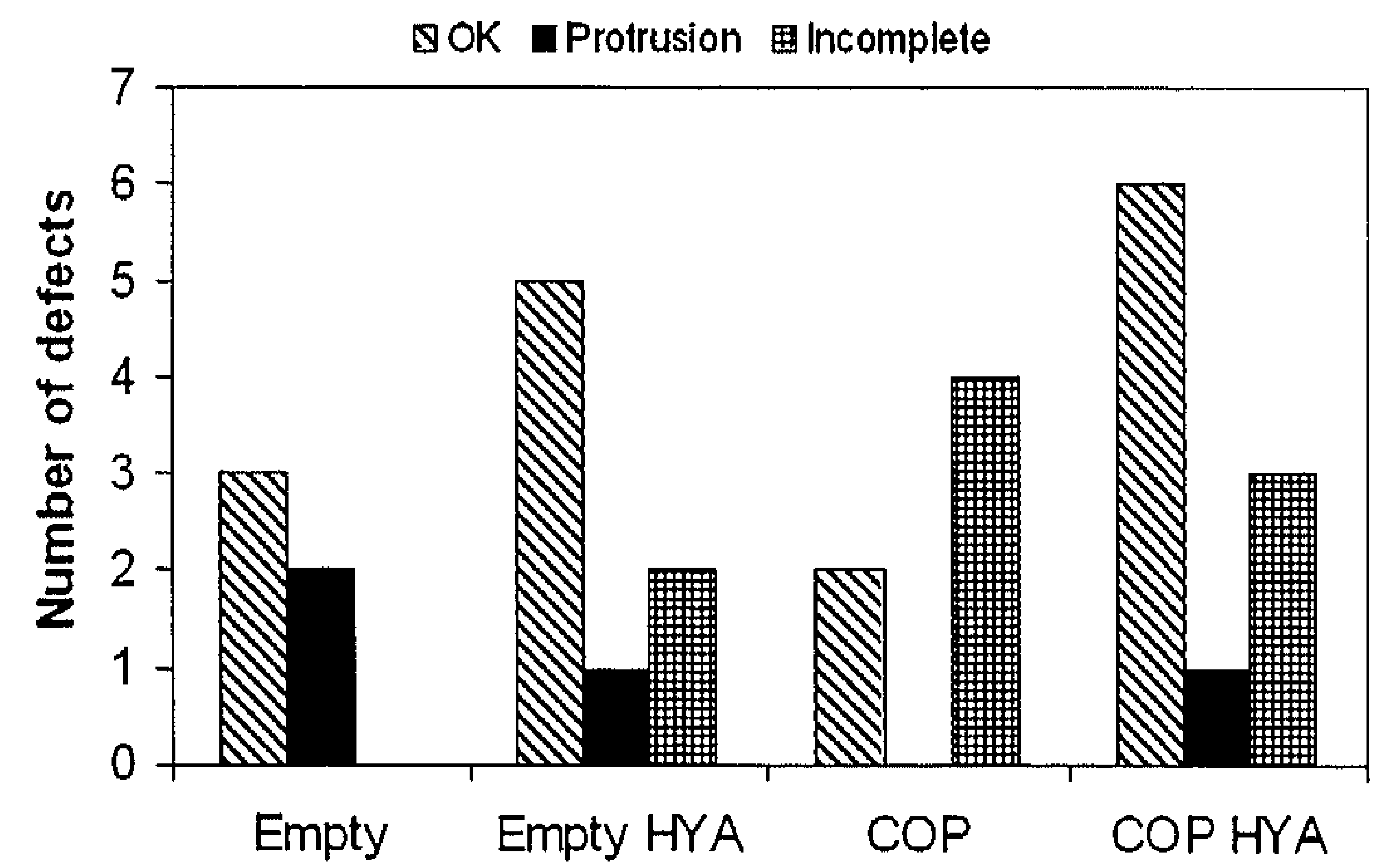

Figure 6: Subchondral bone repair after 3 months of follow-up. Subchondral bone repair was scored as level (OK), as protruding into the articular cartilage, and as incomplete. Empty and treated defects, taken together, were repaired significantly better in the presence of hyaluronan (HYA) than in the absence of HYA. COP, cartilage out of periosteum. 
Repair of osteochondral defects with ectopical cartilage

\section{DISCUSSION}

This study is a conceptual study in which we illustrate that it is possible to produce cartilaginous tissue at an ectopic location in a rabbit and to use this tissue to fill and repair an osteochondral defect in the knee joint of the same animal. This is a novel mode of tissue engineering, in which cell isolation and cultures in a laboratory are no longer necessary.

This study was performed in 6-months old rabbits which are still young and skeletally hardly mature. The age of the animal or patient may be important in determining the success rate of the cartilage induction procedure, because the number of cambium layer cells in periosteum, which are suggested to form the cartilagenous tissue, rapidly decreases with age ${ }^{27,28}$. However, two recent studies showed that it is possible to stimulate periosteal cells from patients of 70 years and older to differentiate into the chondrogenic lineage ${ }^{29,30}$.

Induction of ectopic cartilage by dissecting a piece of periosteum was successful in $93 \%$ of the cases. Although this already is a high number, in order to use this procedure in the clinic a success rate close to $100 \%$ may be necessary. This may be achieved by optimizing the induction method of ectopic cartilage. Other ways to stimulate periosteal cells to proliferate and differentiate have been explored ${ }^{17,31}$ and may result in higher success rates and more reproducible, highquality tissue. Also, during the operation to induce cartilage formation an arthrotomy was performed to produce a cartilage-only defect and factors from the synovial fluid may affect the induction of ectopic cartilage. Positive effects of HYA and synovial fluid on the differentiation of mesenchymal 'stem' cells from bone marrow have been described ${ }^{32}$.

The thickness of the ectopic cartilage at 14 days postinduction was $2,05 \mathrm{~mm}$, which is quite sufficient to repair articular cartilage in a rabbit, which is $120-$ $200 \mu \mathrm{m}$ thick. The thickness of human articular cartilage is $2-6 \mathrm{~mm}$, so in order to repair human articular cartilage defects thicker ectopic cartilage needs to be induced.

Treatment of osteochondral defects with ectopic cartilage reduced the frequency at which animals limped. This indicates a significant reduction in experienced pain. Whether the filling of the defect also reduces degeneration of the edges of the original cartilage will depend on the quality of the grafted tissue: in order to do so, the mechanical properties of the grafted tissue should be comparable to those of the original cartilage. However, the chance that degeneration will be less is much higher than with methods in which tissue has to grow in situ, such as $\mathrm{ACI}$, perichondrium transplantation and periosteum transplantation.

Histologically, the grafted tissue remained its viability both at 3 weeks and at 3 months postimplantation. This is in contrast to tissue-engineered cartilage in which cell viability gradually decreased ${ }^{33}$. 
The repair tissue in the osteochondral defect had many aspects of hyaline cartilage. All the grafted tissues stained positive with antibodies for collagen type II at 3 weeks and 3 months follow-up. Next, at 3 months of follow-up, in most cases proper orientation of chondrocytes was also observed, and sometimes even a tidemark.

The addition of HYA in general improved the repair reaction. The results of empty defects treated with HYA were as good as those of ectopic cartilagetreated defects without HYA at 3months follow-up. The quality of the repair as assessed by modified O'Driscoll score was again better when HYA was added to ectopic cartilage treated defects. The differences are small and can be attributed to the observed effect of HYA on the subchondral bone repair, because subchondral bone repair is an intrinsic part of the score. The positive effect of HYA on the subchondral bone repair reaction was unforeseen. Protective effects of HYA on chondrocytes have been described and that was why HYA was tested in these repair reactions ${ }^{15}$. It is possible that HYA also functions in the control of the hypertrophic differentiation of chondrocytes and the subsequent subchondral bone growth. Further research will be needed to elucidate this effect of HYA and to determine whether addition of HYA may be an alternative for administration of Indomethacin, which has been shown to inhibit (prevent) bone protrusion in clinical articular cartilage repair procedures ${ }^{12,34}$.

An important issue which should also be mentioned here is the change of chondrocytes from transient cells (ectopic cartilage, which transforms into bone in 40 days) to permanent cells (hyaline cartilage at the repair site at 3-months of follow-up). This process, which occurs in embryos, is not well understood. Whether Tenascin-C, which is a marker for permanent cells, and the transcription factors Runx-2 and C-1-1 play a role in this process needs to be elucidate ${ }^{35-38}$. In considering this phenomenon, it was interesting to note that 35 days (14 days at transplantation plus 21 days at [ 3 week evaluation]) after induction the implant remained largely in its chondrogenic phase as seen at thionine staining and collagen type II staining. In contrast, reactive periosteal tissue is completely transformed into bone after 40 days if left at site of induction ${ }^{16}$.

The described procedure of repair of an osteochondral defect with ectopically produced cartilage has several advantages over the tissue-engineering methods currently used in the clinic. First, there is no need to harvest cartilage from the affected joint, so in this joint there will be no donor site morbidity. Second, the time span between induction and transplantation of ectopic cartilage was 14 days (in rabbits). This is relatively short compared to the time needed to isolate, expand and seed chondrocytes from harvested cartilage. These procedures are prone to mistakes and infections and require a number of 
safety requirements, which make them expensive. Using the patient's own body as a cartilage-generating reactor eliminates all these issues and may evolve in a cheap and versatile way to produce cartilage for articular surface repair.

\section{Acknowledgements}

The monoclonal antibody developed by T.F. Linsenmayer et al. (II-II6B3) was obtained from the Developmental Studies Hybridoma Bank developed under auspices of the NICHD, and maintained by the Department of Biological Sciences of the University of Iowa (Iowa City, IA). The help provided by May Bost, Petra Dijkstra, Joyce Suyk and Monique de Jong (Central Experimental Animal Facility, University Maastricht) with the animal experiments is great fully acknowledged.

\section{REFERENCES}

1. Ficat P, Ficat C, Gédéon P. Arthrose post-traumatique et chondrose post-contusive. Revue de Chirurgie et Orthopaedie 1978; 64:19-34.

2. Engkvist $\mathrm{O}$, Ohlsen L, Johansson S, Skoog T. Reconstruction of articular cartilage using autologous perichondrial grafts. A preliminary report. Scandinavian Journal of Plastic and Reconstructive Surgery 1975; 9: 203.

3. Engkvist $O$, Wilander E. Formation of cartilage from rib perichondrium grafted to an articular cartilage defect in the femoral condyle of the rabbit. Scandinavian Journal of Plastic and Reconstructive Surgery 1979; 13:371-376.

4. Homminga GN, van der Linden AJ, Terwindt-Rouwenhorst EAW, Drukker J. Repair of Articular Defects by Perichondrial Grafts. Experiments in the Rabbit. Acta Orthopaedica Scandinavica 1989;60(3): 326-329.

5. Homminga GN, Bulstra SK, Bouwmeester PSM, van der Linden AJ. Perichondral grafting for cartilage lesions of the knee. Journal of Bone and Joint Surgery. British 1990; 72-B(6): 1003-1007.

6. Pridie KH. A method of resurfacing osteoarthritic knee joints. Journal of Bone and Joint Surgery. British 1959; 41-B: 618-619.

7. Steadman JR, Rodkey WG, Rodrigo JJ. Microfracture: surgical technique and rehabilitation to treat chondral defects. Clin Orthop 2001; 391S: S362-9.

8. Blevins FT, Steadman JR, Rodrigo JJ, Silliman J. Treatment of articular cartilage defects in athletes: an analysis of functional outcome and lesion appearance. Orthopedics 1998;21(7): 761-768.

9. Hangody L, Kish G, Kárpáti Z, Szerb I, Udvarhelyi I. Arthroscopic autogenous osteochondral mosaicplasty for the treatment of femoral condylar articular defects. Knee Surg Sports Traumatology Arthroscopy 1997; 5: 262-267.

10. Hangody L, Kish G, Kárpáti Z, Udvarhelyi I, Szigeti I, Bély M. Mosaicplasty for the treatment of articular cartilage defects: Application in clinical practice. Orthopedics 1998; 21(7): 751756.

11. Brittberg M, Lindahl A, Nilsson A, Ohlsson C, Isaksson O, Peterson L. Treatment of deep cartilage defects in the knee with autologous chondrocyte transplantation. New England Journal of Medicine 1994; 331: 889-895. 
12. Bouwmeester SJM, Beckers JMH, Kuijer R, van der Linden AJ, Bulstra SK. Long-term results of rib perichondrial grafts for the repair of cartilage defects in the human knee. International Orthopaedics 1997; 21:313-317.

13. McDevitt CA, Muir $\mathrm{H}$. Biochemical changes in the cartilage of the knee in experimental and natural osteoarthritis in the dog.J Bone Joint Surg Br 1976;58(1): 94-101.

14. Knutsen G, Engebretsen L, Ludvigsen TC, Drogset JO, Grontvedt T, Solhein E, et al. Autologous chondrocyte implantation compared with microfracture in the knee. A randomized trial. J Bone Joint Surg Am 2004; 86-A(3): 455-64.

15. Fujita Y, Kitagawa M, Nakamura S, Azuma K, Ishii G, Higashi M, et al. CD44 signaling through focal adhesion kinase and its anti-apoptotic effect. FEBS Lett 2002; 528(1-3):101-8.

16. Emans PJ, Surtel DAM, Frings EJJ, Bulstra SK, Kuijer R. In vivo generation of cartilage out of periosteum. Tissue Engineering 2005; accepted.

17. Stevens MM, Qanadilo HF, Langer R, Prasad Shastri V. A rapid-curing alginate gel system: utility in periosteum-derived cartilage tissue engineering. Biomaterials 2004;25(5):887-894.

18. Maneiro E, de Andres MC, Fernandez-Sueiro JL, Galdo F, Blanco FJ. The biological action of hyaluronan on human osteoartritic articular chondrocytes: the importance of molecular weight. Clin Exp Rheumatol 2004; 22(3): 307-12.

19. Almarza AJ, Athanasiou KA. Design characteristics for the tissue engineering of cartilaginous tissues. Ann Biomed Eng 2004; 32(1): 2-17.

20. Kawano T, Miura H, Mawatari T, Moro-Oka T, Nakanishi Y, Higaki H, et al. Mechanical effects of the intraarticular administration of high molecular weight hyaluronic acid plus phospholipid on synovial joint lubrication and prevention of articular cartilage degeneration in experimental osteoarthritis. Arthritis Rheum 2003; 48(7): 1923-9.

21. Petrella RJ, DiSilvestro MD, Hildebrand C. Effects of Hyaluronate Sodium on Pain and Physical Functioning in Osteoarthrtitis of the Knee. Archives of Internal Medicin 2002;162:292298.

22. EJPJansen, MM Hulsbosch., Terwindt-Rouwenhorst E, al. e. Animal model for degenerative articular cartilage using previously created full-thickness cartilage defects. (submitted).

23. van Susante JL, Buma P, Schuman L, Homminga GN, van den Berg WB, Veth RP. Resurfacing potential of heterologous chondrocytes suspended in fibrin glue in large full-thickness defects of femoral articular cartilage: an experimental study in the goat. Biomaterials 1999 20(13): 1167-75.

24. Moojen DJ, Saris DB, Auw Yang KG, Dhert WJ, Verbout AJ. The correlation and reproducibility of histological scoring systems in cartilage repair. Tissue Eng 2002;8(4):62734.

25. O'Driscoll SW, Keeley FW, Salter RB. Durability of regenerated articular cartilage produced by free autogenous periosteal grafts in major full-thickness defects in joint surfaces under the influence of continuous passive motion. A follow-up report at one year. Journal of Bone and Joint Surgery. American 1988; 70-A(4): 595-606.

26. O'Driscoll SW, Keeley FW, Salter RB. The chondrogenic potential of free autogenous periosteal grafts for biological resurfacing of major full-thickness defects in joint surfaces under the influence of continuous passive motion. Journal of Bone and Joint Surgery. American 1986; 68-A(7): 1017-1035.

27. Nakahara H, Goldberg VM, Caplan AI. Culture-expanded periosteal-derived cells exhibit osteochondrogenic potential in porous calcium phosphate ceramics in vivo. Clinical Orthopaedics and Related Research 1992; 276: 291-298.

28. Nakahara H, Goldberg VM, Caplan AI. Culture-Expanded Human Periosteal-Derived Cells Exhibit Osteochondral Potential In Vivo. Journal of Orthopaedic Research 1991; 9: 465476. 
Repair of osteochondral defects with ectopical cartilage

29. De Bari C, Dell'Accio F, Luyten FP. Human periosteum-derived cells maintain phenotypic stability and chondrogenic potential throughout expansion regardless of donor age. Arthritis Rheum 2001; 44(1): 85-95.

30. Kuijer R, Emans PJ, Jansen EJP, Hulsbosch MM, Surtel DAM, Bulstra SK. Isolation and cultivation of chondrogenic precursors from aged human periosteum. Transactions of the Orthopaedic research society 2003;28: 101 .

31. Simon T, Van Sickle D, Kunishima D, Jackson D. Cambium cell stimulation response to surgival release of overlying periosteal tissue. 47th Annual Meeting, ORS 2001; Poster 0503.

32. Hegewald AA, Ringe J, Bartel J, Kruger I, Notter M, Barnewitz D, et al. Hyaluronic acid and autologous synovial fluid induce chondrogenic differentiation of equine mesenchymal stem cells: a preliminary study. Tissue and Cell $2004 ; 36(6): 431-438$.

33. Mierisch CM, Wilson HA, Turner MA, Milbrandt TA, Berthoux L, Hammarskjold ML, et al. Chondrocyte transplantation into articular cartilage defects with use of calcium alginate: the fate of the cells. J Bone Joint Surg Am 2003; 85-A(9): 1757-67.

34. Nehrer S, Spector M, Minas T. Histologic Analysis of Tissue After Failed Cartilage Repair Procedures. Clinical Orthopaedics and Related Research 1999; 365: 149-162.

35. Koyama E, Leatherman JL, Shimazu A, Nah HD, Pacifici M. Syndecan-3, tenascin-C, and the development of cartilaginous skeletal elements and joints in chick limbs. Dev Dyn 1995; 203(2): 152-62.

36. Koyama E, Shimazu A, Leatherman JL, Golden EB, Nah HD, Pacifici M. Expression of syndecan-3 and tenascin-C: possible involvement in periosteum development.J Orthop Res 1996; 14(3): 403-12.

37. Pacifici M, Iwamoto M, Golden EB, Leatherman JL, Lee YS, Chuong CM. Tenascin is associated with articular cartilage development. Dev Dyn 1993; 198(2): 123-34.

38. Iwamoto M, Koyama E, Enomoto-Iwamoto M, Pacifici $M$. The balancing act of transcription factors C-1-1 and Runx2 in articular cartilage development. Biochem Biophys Res Commun 2005; 328(3): 777-82. 


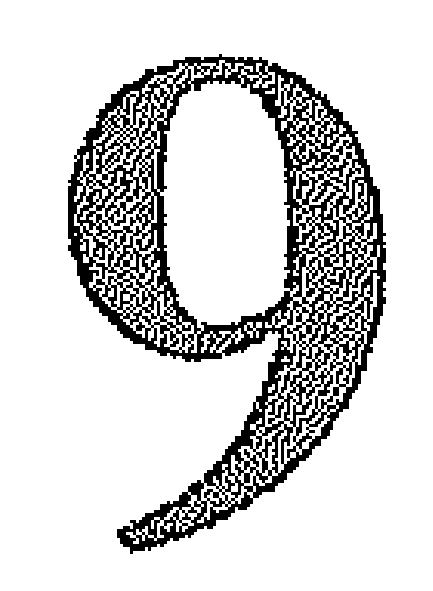

Summary, Discussion and

Future Prospects 
Cartilage lesions have a limited ability for self repair and may even evolve in premature osteoarthritis (OA). Microfracturing or drilling of the subchondral bone are among the first attempts to heal cartilage lesions. These techniques enable mesenchymal progenitor cells, originating from the bone marrow, to penetrate into the cartilage lesion. Although clinical results may improve, the healing process thus far seems inadequate since no functional hyaline cartilage but fibrocartilage is formed. Due to the progress in the field of 'Tissue Engineering (TE), possibilities for the treatment of cartilage defects have improved considerably. Periosteal and perichondrial Arthroplasty, Autogenic Chondrocyte Transplantation (ACT), matrix-assisted ACT and mosaicplasty are the latest clinically applied techniques.

However culturing of cells, (e.g. in ACT) implies detailed and time consuming protocols, making these techniques expensive. Other drawbacks of these latest techniques are that the autogenic chondrocytes are isolated from a biopsy of articular cartilage taken from the affected joint. This way the joint is further damaged and donor site morbidity has to be taken into account.

The overall aim of this thesis was to examine periosteum as an alternative cell source for the repair of cartilage lesions. Currently periosteum as a complete tissue is used as a graft, for instance in ACT and periosteum transplantation. Exploring the possibilities of this tissue with its osteochondrogenic progenitor cells may lead to enhanced cartilage repair techniques, avoiding further joint damage as in techniques such as ACT and mosaicplasty.

In order to study cartilage repair, histological judgment of the tidemark and calcified cartilage layer is of critical importance. We have examined the effect of different decalcification protocols on general cartilage staining and the ability to use the terminal deoxy(d)-UTP nick end labeling (TUNEL) technique for studying apoptosis.(Chapter 3 ).

This study demonstrated that decalcification with $10 \%$ EDTA is the best way to preserve the cartilage matrix integrity as well as the chondrocytes. Avoiding nuclear damage is of the utmost importance when studying cell apoptosis with the TUNEL technique. Reading different reports it seems that the amount of apoptosis in OA cartilage is highly controversial; this may be caused by digestion of the matrix using proteinase $\mathrm{K}$. In chapter 3 an alternative for proteinase $\mathrm{K}$ digestion is described: fixation with methacarn proved to be far less harmful to the cells and resulted in more consistent results.

Periosteum is a potential source for osteochondral progenitor cells originating from the periosteal cambium layer, which is adjacent to the bone. It is known that the chondrogenic capacity of periosteum decreases with age in a rabbit model. 
Others have reported that human periosteum-derived cells maintain their chondrogenic potential throughout expansion regardless of donor age. We have examined the proliferation rate and the chondrogenic capacity of aged human periosteal cells exploring different culture conditions and growth factors (Chapter 4). For this purpose periosteum of the upper medial tibia was harvested from patients having a total knee replacement. Cells were isolated and the effect of addition of different nutrients and growth factors on cell proliferation and differentiation was examined. The use of Fetal Bovine Serum (FBS) proved to be essential for proliferation of aged human periosteal cells. Proliferation was enhanced by addition of FGF-2. Replacement of L-valine with Dvaline in the culture medium, as in MEM (D)-valine, seemed to prevent fibroblast overgrowth. Using this medium, periosteal cells of aged patients had, although variable, chondrogenic potential. TGF- $\beta$ isomers were essential for inducing chondrogenic differentiation of periosteal cells. The cambium layer of aged human periosteum is much thinner than in the young patient making a good control of harvesting this layer virtually impossible. Overall, the heterogeneity of periosteal cell cultures and the lack to control the amount of progenitor cells may imply a variation in chondrogenesis when these cells, isolated from aged patients, are used as chondrogenic cell source.

In cell-based therapies isolated cells are after expansion in cell cultures, transplanted in the hostile conditions of a wound bed and experience cytokines, polymorphonuclear cells, mechanical forces etc. which may affect cell viability. This was studied by transplanting CMDil fluorochrome-labeled, autogenic chondrocytes and periosteal cells seeded in PEGT/PBT scaffolds into osteochondral defects in rabbits (Chapter 5). After confirmation that transfer of label to endogenous cells did not take place within 5 days and the fluorochrome itself did not have any adverse effects on cell viability, cell survival was examined 5 days post-implantation. Different conditions which may affect cell viability were tested: (i) the type of cells: chondrocytes versus periosteal cells, (ii) the type of serum to supplement the culture medium: Fetal Bovine Serum (FBS) or Autogenic Serum (AS), (iii) the structure of the scaffold: Compression Moulded (CM) scaffolds versus Rapid Prototyped (RP) scaffolds. The latter have increased pore interconnectivity. In addition hyaluronan (HYA) was tested as a cell-protective agent.

The effectiveness of any cellular approach will depend on the retention of cell viability early after implantation. Chondrocytes survived the implantation into an osteochondral defect much better than periosteal cells. The tested factors did not seem to influence cell survival substantially. Addition of HYA increased the amount of viable periosteal cells. Chondrocytes originate from a non-vascular tissue dominated by mechanical forces and low oxygen levels. 
Apparently, chondrocytes seem to be preconditioned for the hostile environment of the damaged joint. This preconditioning appeared to be maintained during expansion of the cells in monolayer cultures. Differentiating progenitor cells into chondrogenic lineage before implantation into an osteo-chondral lesion may enhance viability.

It would be ideal to stimulate periosteum in vivo to persuade the cambium layer to proliferate and differentiate into an ectopic cartilage as can be seen during fracture healing (Chapter 6). For this purpose we damaged the periosteum of skeletally mature New Zealand White rabbits by dissecting a piece of periosteum from the upper medial tibia. Cell proliferation and differentiation were examined at the wound edges of the periosteal defect. Initially (after 10 days), this led to the formation of an ectopic cartilage. In time this cartilage calcified (20 days) and was replaced by bone (completed within 40 days). These findings were confirmed by thionine staining, immunohistochemical staining of collagen types I and II and gene expression of chondrogenic and osteogenic markers. During fracture healing periosteal cells, endosteal cells and bone marrow cells (BMC's) contribute to the callus formation. BMC's are considered to be the main cell source for fracture repair. Our findings confirm that periosteum also plays an important role in callus formation. This model can be used to study endochondral bone formation, providing useful information for tissue engineering of cartilage and bone and a better understanding of fracture healing.

Endochondral bone formation is a multistep pathway in which chondrogenesis is followed by osteogenesis. The role and expression of important growth factors (Transforming Growth Factor B, Bone Morphogenic Proteins (BMP's) 2,-4,-7), Indian Hedgehog (Ihh) and Parathyroid Hormone related Protein (PTHrP), transcription factors Sox9 and Runx2, and adhesion molecules (periostin) have been studied in in-vitro models. Also cell metabolism in the first, presumably hypoxic, chondrogenic phase is largely unknown (expression of GAPDH, Hypoxia Inducible Factor (HIF) $-1 \alpha$ and Vascular Endothelial Growth Factor (VEGF)). Our new in-vivo model enabled us to study the expression of these factors in time (Chapter 7). Interestingly, TGF- $\beta_{1}$ and members of its superfamily such as BMP-2, -4 and -7 were detected by immunohistochemistry during chondrogenesis $(\mathrm{t}=10)$ but no up-regulation was detected by the real time PCR. This may indicate that the production of these factors was regulated at a post-transcriptional level. Sox9, was up-regulated during chondrogenesis, which suggests that the function and kinetics of this transcription factor in ectopic cartilage formation is comparable to the cartilage formation during endochondral bone formation in an embryo and during callus formation. No exclusive evidence was found that this was regulated by the 
Ihh/PTHrP interplay as is occurring in the growth plate. Periostin mRNA upregulation and immunolocalization were present during chondrogenesis. Periostin is an adhesion molecule with presently unknown function. It has been suggested to enhance the recruitment and attachment of osteo-chondro progenitor cells during fracture healing. This molecule is known to be up-regulated during hypoxia. The presence of HIF-1 $\alpha$ and the up-regulation of GAPDH and HIF-1 $\alpha$ indicate a hypoxic environment, and an anaerobic metabolism. Cell survival after implantation into an osteochondral defect might be influenced by hypoxia. HIF-1 $\alpha$ has been shown to play an important role for chondrocyte survival under hypoxic conditions.

In order to study graft ingrowth, graft survival, and cartilage repair, 14 days after induction, ectopic cartilage grafts were implanted into $3 \mathrm{~mm}$ diameter osteochondral defects (Chapter 8). Three weeks and three months after implantation specimens were evaluated histologically. At 3 weeks follow up grafts were viable and had an excellent ingrowth in the surrounding bone. After three months the joint surface at the site of the defect stained positive for Collagen Type II. In several samples a newly formed tidemark and tissue architecture like in healthy mature articular cartilage were found. This was reflected in the O'Driscoll scores for articular cartilage repair, which were significantly higher if ectopic cartilage grafts were implanted (compared with empty controls). Addition of hyluronan enhanced the repair process and improved subchondral bone healing. After implantation the graft was exposed into an environment with mechanical forces and synovial fluid. This change of environment is likely the main factor of maintaining the surface of the transplanted graft in a chondrogenic phase even at a follow-up of 3 months. Although ossification was not observed after a follow-up period of 3 months, calcification and factors, which may influence this process, have to be studied in the long term. Also the method of generating cartilage from periosteum needs to be optimized, since many progenitor cells are lost by dissecting periosteum. Injection of a gel between bone and periosteum is an interesting and elegant method to induce and control subperiosteal cartilage formation.

In summary, decalcification with 10\% EDTA is the decalcification method of choice if cartilage has to be evaluated histologically. We showed that the chondrogenic potential of isolated periosteal cells was maintained in aged patients. However, harvesting, isolating and culturing these cells is difficult and time consuming. Moreover, after expansion in monolayer, only a small percentage of periosteal cells survive the transplantation in a damaged joint. Generating cartilage from periosteum is possible; this provides homologous ectopically produced cartilage grafts that are large enough to fill large osteochondral defects (in rabbits). This novel method can also be used as a 
Chipter $)$

136

model to study periosteal endochondral bone formation. Finally, implantation of periosteum derived cartilage improved the repair of osteochondral defects. The repair was further enhanced by the addition of hyaluronan. This novel way of tissue regeneration bypasses expensive and time consuming laboratory techniques without further damage to the joint, thus holds promise as a procedure for articular cartilage repair.

\section{FUTURE PROSPECTS}

Currently a project called; "Tissue engineering of cartilage using the "in situ incubator": a novel therapeutic approach" was started to further exploit the full potential of periosteal, in vivo derived cartilage. Three main goals have been formulated (i) Improving the success rate, the ability to control the process of ectopic cartilage formation from periosteum. This is thought to be essential to optimize the "in situ incubator" concept for human application. (ii) Improved insight into the "multipotency" and proliferative capacity of periosteal progenitor cells and a better understanding of the key factors and conditions that promote chondrogenesis (c.q. block osteogenesis) are essential to successful development of this and other potential clinical application (e.g. restoration of bone defects). (iii) Thorough understanding of factors and conditions influencing cell fate post implantation and prevention of subchondral bone protrusion (e.g growth factors, hypoxia, indomethacin, hyaluronic acid etc.). 
Samenvatting, Discussie en Toekomstverwachtingen 
Kraakbeendefecten hebben een beperkte capaciteit om zelf te genezen en kunnen leiden tot vroegtijdige arthrose. Microfracturing en het opboren van het subchondrale bot behoren tot de eerste pogingen om krakbeendefecten te herstellen. Door deze technieken kunnen mesenchymale stamcellen, die afkomstig zijn uit het beenmerg, het kraakbeendefect bereiken. Hoewel klinisch het resultaat kan leiden tot verbetering, is het genezingsproces niet in staat om kwalitatief goed hyalien kraakbeen aan te maken. Juist het slechtere fibreuze kraakbeen wordt gemaakt. De mogelijkheden om kraakbeendefecten te behandelen zijn aanzienlijk toegenomen door ontwikkelingen op het gebied van Tissue Engineering (TE). Periosteum en perichondium artroplastiek, Autologe Chondrocyt Transplantatie (ACT), matrix-geassisteerde ACT (MACT) en mosaicplastiek zijn nu klinisch toepasbare technieken.

Ingewikkelde, tijdrovende en dure technieken zijn echter nodig voor het opkweken van de cellen (bijvoorbeeld in ACT). Een ander nadeel van deze technieken is het feit dat er een stuk gewrichtskraakbeen geoogst moet worden van de reeds beschadigde knie. Hierdoor wordt de knie verder beschadigd en moet er rekening gehouden worden met donorzijde morbiditeit.

Het doel van dit proefschrift was om te onderzoeken of periost (botvlies) een alternatieve bron kan zijn voor cellen die gebruikt kunnen worden om kraakbeendefecten te behandelen. Op dit moment wordt periost als weefsel gebruikt in technieken zoals ACT en periost transplantatie. Onderzoek van dit weefsel met zijn voorlopercellen die zowel richting bot als kraakbeen kunnen differentiëren, kan leiden tot verbeterde methoden om kraakbeendefecten te genezen. Indien dit mogelijk is, kan extra beschadiging van het gewricht door het nemen van een kraakbeen biopt, zoals in technieken als ACT en mosaicplastiek, vermeden worden.

Om herstel van kraakbeen te bestuderen is het belangrijk om de tidemark (overgang verkalkt kraakbeen en niet verkalkt kraakbeen) en de verkalkte krakbeenlaag op histologisch niveau goed te kunnen beoordelen. We hebben het effect bestudeerd van verschillende ontkalkingprotocollen op kraakbeenkleuring en op de terminal deoxy(d)-UTP nick end labeling (TUNEL) techniek. De latste techniek wordt gebruikt om de mate van apoptose (geprogrammeerde celdood) te bestuderen (Hoofdstuk 3). Deze studie liet zien dat de ontkalking met 10\% EDTA de beste methode is om schade aan de celkernen van de chondrocyten te voorkomen. Ook de kleuring van de kraakbeenmatrix blijft optimaal na ontkalking met 10\% EDTA. Schade aan de celkern moet voorkomen worden om apoptose te bestuderen met behulp van de TUNEL techniek. In de literatuur worden verschillende waarden genoemd voor de mate van apoptose in arthrotisch kraakbeen. Dit kan veroorzaakt zijn door verschillen in de protocollen van digestie van de matrix (wel/niet gebruik 
van enzymen zoals proteinase K) in de TUNEL gebaseerde studies. In hoofdstuk 3 is een alternatief voor het gebruik van proteinase $\mathrm{K}$ beschreven; fixatie met methacarn gaf minder verlies van celkernen en meer consistente resultaten.

Periost is een potentiële bron voor osteochondrale voorlopercellen. Deze cellen zitten in de cambiumlaag van het periost. Deze cambiumlaag ligt tegen de botzijde aan. Bij het konijn neemt de chondrogene capaciteit van periost af met de leeftijd. Sommige onderzoekers hebben beschreven dat cellen van humaan botvlies deze capaciteit behouden ongeacht de leeftijd van de donor. Wij hebben uitgezocht welke kweekcondities en groeifactoren van belang zijn voor een optimale proliferatie. Hierna hebben we de chondrogene capaciteit van humane periostcellen van oude donoren bepaald en ook hierbij de invloed van het gebruik van verschillende kweekcondities en groeifactoren onderzocht (Hoofdstuk 4). Hiervoor werd het periost geoogst van patiënten die een totale knieprothese kregen. Cellen werden geïsoleerd en het effect van toevoeging van verschillende nutriënten en groeifactoren op celproliferatie en differentiatie werden bestudeerd. Het gebruik van Fetal Bovine Serum (FBS) was essentieel voor de proliferatie van humane periostcellen van oude donoren. Door toevoeging van FGF-2 nam de proliferatie snelheid toe. Vervanging van Lvaline met $D$-valine in het kweekmedium zoals in MEM (D)-valine leek fibroblastovergroei te voorkomen. Met behulp van dit medium werd, hoewel variabel, chondrogene differentiatie van periostcellen aangetoond. TGF- $\beta$ isomeren waren essentieel voor de chondrogene differentiatie van periost cellen. De cambiumlaag van oude donoren is veel dunner dan de cambiumlaag in jonge donoren. Hierdoor is een goede controle van de kwaliteit van het periost na het oogsten vrijwel onmogelijk. De heterogeniteit van de celpopulatie (fibroblasten en voorlopercellen) en het niet kunnen controleren van de hoeveelheid voorlopercellen tijdens het oogsten en opkweken leidt tot variabele bevindingen m.b.t. de chondrogene capaciteit.

In therapieën waarbij cellen worden geïsoleerd, opgekweekt en daarna geimplanteerd, wordt het implantaat blootgesteld aan een vijandige omgeving nl. een wondbed waarin zich cytokines, polynucleaire leucocyten, mechanische krachten etc. bevinden. Dit kan de levensvatbaarheid van de getransplanteerde cellen beïnvloeden. Wij hebben de levensvatbaarheid van cellen bestudeerd. Hiervoor zijn de autologe chondrocyten en periostcellen gelabeld met het CMDil fluochrome. Deze cellen zijn uitgezaaid in een PEGT/PBT scaffold. Daarna is de scaffold met de cellen erin geimplanteerd in een osteochondraal defect (Hoofdstuk 5). Overleving van getransplanteerde cellen werd bestudeerd na 5 dagen. Vantevoren hebben we vastgesteld dat er geen transfer plaatsvond van label op endogene cellen binnen 5 dagen en dat het label zelf geen nadelige effecten had op levensvatbaarheid van de cellen. Verschillende 
Chapter

condities die overleving van cellen zouden kunnen beïnvloeden werden bestudeerd; (i) type cel: chondrocyten versus periost cellen, (ii) type serum dat toegevoegd werd an het kweekmedium: Fetal Bovine Serum (FBS) of Auloloog Serum (AS), (iii) structuur van de scaffold: Compression Moulded (CM) scaffolds versus Rapid Prototyped (RP) scaffolds. De laatste heeft een betere "pore interconnectivity". Verder werd toevoeging van hyaluronan (HYA), dat mogelijk een celbeschermende werking heeft, getest. De effectiviteit van elke methode warin cellen gebruikt worden hangt af van de levensvatbaarheid van de getransplanteerde cellen. Chondrocyten overleefden de transplantatie veel beter dan periostcellen. De geteste factoren leken de levensvatbaarheid van de getransplanteerde cellen niet wezenlijk te beïnvloeden. Door toevoeging van HYA nam het percentage levende periostcellen toe. Chondrocyten komen uit een omgeving zonder bloedvaten, gedomineerd door mechanische krachten en met een lage zuurstofspanning. Het lijkt erop dat chondocyten meer dan periostcellen voorbereid zijn op de vijandige omgeving van een beschadigd gewricht. Deze preconditionering van chondrocyten lijkt gehandhaafd te worden tijdens de expansie van deze cellen gedurende de kweek in monolayer. Het differentiëren van voorlopercellen richting kraakbeencel voor transplantatie in een osteochondraal defect zou het percentage dat de transplantatie overleefd kunnen verhogen.

Het zou ideaal zijn om het periost in situ te stimuleren zodat de cambiumlaag prolifereert en differentieert tot ectopisch kraakbeen zoals dit proces gezien wordt bij fractuurgenezing. In dit geval is het niet nodig om chondrocyten te oogsten in het gewricht, dat immers tot nog meer gewrichtsbeschadiging zal leiden. Eveneens wordt het gebruik van de ingewikkelde en tijdrovende kweekmethoden voorkomen (Hoofdstuk 6). We hebben de celproliferatie en differentiatie onderzocht aan de randen van een botvliesdefect. Dit defect is gemaakt aan de proximale mediale zijde van de tibia bij volwassen New Zealand White konijnen. Aanvankelijk (na 10 dagen), leidde dit tot de vorming van ectopisch kraakbeen. Na enige tijd verkalkte dit kraakbeen (na 20 dagen) en werd vervangen door bot (binnen 40 dagen). Deze bevindingen werden bevestigd met thionine kleuring, immunohistochemische kleuring van Collageen Types I en II en mRNA expressie van chondrogene en osteogene markers. Cellen afkomstig uit het periosteum, endosteum en de beenmergcellen (BMC) dragen bij aan callusvorming. BMC's worden beschouwd als de belangrijkste celbron bij de fractuurgenezing. Onze bevindingen tonen aan dat ook het periost een belangrijke rol in de callusvorming speelt. Dit model kan gebruikt worden om endochondrale botvorming te bestuderen.

Endochondrale botvorming bestaat uit een aantal stappen waarin chondrogenese gevolgd wordt door osteogenese. De rol en de expressie van de belang- 
rijke groeifactoren (Transforming Growth Factor $\beta$, Bone Morphogenic Proteins (BMP'S) 2, -4, -7), Indian Hedgehog (Ihh) en Parathyroid Hormone related Protein (PTHrP), transcriptiefactoren Sox9 en Runx2, en adhesiemoleculen (periostin) zijn voornamelijk in vitro bestudeerd. Ook het celmetabolisme is in de eerste, vermoedelijk hypoxische, chondrogene fase, grotendeels onbekend (expressie van GAPDH, Hypoxia Inducible Factor (HIF) $-1 \alpha$ en de Vasculaire Endothelial Growth Factor (VEGF)). Met behulp van ons nieuwe model kunnen we deze factoren in vivo bestuderen (Hoofdstuk 7). Immunohistochemische kleuringen op TGF- $\beta$ en BMP-2, -4 en -7 waren positief tijdens de chondrogenese $(t=10)$, maar er was geen up-regulatie op mRNA niveau. Dit kan erop wijzen dat de productie van deze factoren op posttranscriptioneel niveau wordt geregeld. Sox9, een belangrijke transcriptiefactor tijdens de chondrogenese, werd ge-upreguleerd. Dit indiceert dat deze transcriptiefactor bij ectopische kraakbeenvorming tot expressie komt op een vergelijkbaar moment als tijdens de endochondrale botvorming en tijdens de callusvorming. Het is niet bewezen dat de Ihh/PTHrP interactie, zoals beschreven bij de groeischijf, op dezelfde manier gereguleerd is als bij de vorming van ectopisch kraakbeen. Periostin mRNA was ge-upreguleerd. Met inmunohistochemie kon dit adhesiemolecuul worden aangetoond. Hoewel de functie van dit molecuul onbekend is, lijkt Periostin een rol te spelen bij rekrutering en adhesie van osteochondroprogenitor cellen tijdens de fractuurgenezing. Het is bekend dat dit molecuul ge-upreguleerd wordt onder hypoxische omstandigheden. $\mathrm{De}$ aanwezigheid van HIF-1 $\alpha$ en upregulatie van GAPDH en HIF-1 $\alpha$ wijst op een hypoxisch milieu en een anaëroob metabolisme.

De overleving van cellen na implantatie in een osteochondral defect zou door hypoxie beïnvloedt kunnen worden. Van HIF-1 $\alpha$ is angetoond dat het een belangrijke rol speelt in de overleving van chondrocyten onder hypoxische omstandigheden.

Om overleving, ingroei en kraakbeenreparatie te bestuderen, werd ectopisch periostaal kraakbeen 14 dagen na inductie geïmplanteerd in osteochondrale defecten (3 mm in diameter) (Hoofdstuk 8). Drie weken en drie maanden na implantatie werd ingroei en kraakbeenherstel histologisch geëvalueerd. De implantaten hadden een periode van 3 weken overleefd en er was een prima ingroei van implantaat in het omliggend bot. Na drie maanden kleurde het oppervlak van het implantaat positief voor Collageen Type II. In verscheidene samples werd een tidemark gezien en toonde de weefselarchitectuur gelijkenis met gezond gewrichtskraakbeen. De O'Driscoll scores voor gewrichtskraakbeenreparatie waren beduidend hoger in de groep waarin osteochondrale defecten werden gevuld met periostaal ectopisch kraakbeen dan in de groep met "lege" defecten. De toevoeging van hyaluronan verbeterde het reparatie- 
proces. $\mathrm{Na}$ implantatie wordt het transplantaat blootgesteld aan mechanische krachten en synoviale vloeistof. Dit zijn waarschijnlijk de belangrijkste factoren waardoor zelfs na een periode van 3 maanden het oppervlak van implantaten kraakbeen bleef. Hoewel verbening van het oppervlak na een vervolgperiode van 3 maanden niet werd waargenomen, moet de mate van verkalking van het implantaat en de factoren die dit proces kunnen beïnvloeden op de lange termijn nog worden bestudeerd. Ook moet de methode om kraakbeen uit periost te maken worden geoptimaliseerd. Veel voorlopercellen gaan nu nog verloren tijdens het verwijderen van het periost van het bot. De injectie van een gel tussen bot en periost is een interessante en elegante methode om subperiostaal kraakbeenvorming te veroorzaken en te controleren.

Samenvattend kan worden gesteld dat ontkalking met 10\% EDTA de beste ontkalkingsmethode is als de kwaliteit van chondrocyten en kraakbeenmatrix histologisch geëvalueerd moeten worden. Wij toonden aan dat het chondrogene potentieel van geïsoleerde periostcellen in oude patiënten nog aanwezig is. Nochtans, het oogsten, isoleren en cultiveren van deze cellen is moeilijk en tijdrovend. $\mathrm{Na}$ expansie in een monolayer overleeft slechts een klein percentage periostcellen de transplantatie in een osteochondraal defect. Het maken van kraakbeen uit periost is mogelijk. Dit leidt tot een homoloog ectopisch geproduceerd kraakbeenimplantaat dat groot genoeg is om grote osteochondrale defecten (bij konijnen) op te vullen. Deze nieuwe methode kan ook als model dienen om periostale endochondrale botformatie te bestuderen. Tenslotte, de implantatie van ectopisch periostaal kraakbeen leidt tot een verbeterde reparatie van osteochondrale defecten. Deze reparatie werd nog meer verbeterd door de toevoeging van hyaluronan. Deze nieuwe manier van weefselregeneratie voorkomt het gebruik van dure en tijdrovende laboratoriumtechnieken en veroorzaakt ook geen verdere schade aan het gewricht.

\section{TOEKOMST}

Momenteel is een project genaamd; " Tissue engineering of cartilage using the "in situ incubator": a novel therapeutic approach" gestart. In dit project zijn drie belangrijke doelstellingen geformuleerd; (i) Verbeteren van het succespercentage om periostaalkraakbeen te genereren onder gestandaardiseerde condities. Dit is essentieel om het "in situ incubator" concept voor menselijke toepassing mogelijk te maken. (ii) Een beter inzicht krijgen in de "multipotency" en de proliferative capaciteit van de periosteale voorlopercellen. (iii) Tevens moet onderzocht worden op welke wijze verbening van het implantaat kan worden voorkomen (b.v. de invloed van groeifactoren, hypoxie, indomethacine, hyaluronan enz.) 
Colour figures chapters 3 to 8 


\section{CHAPTER 3}

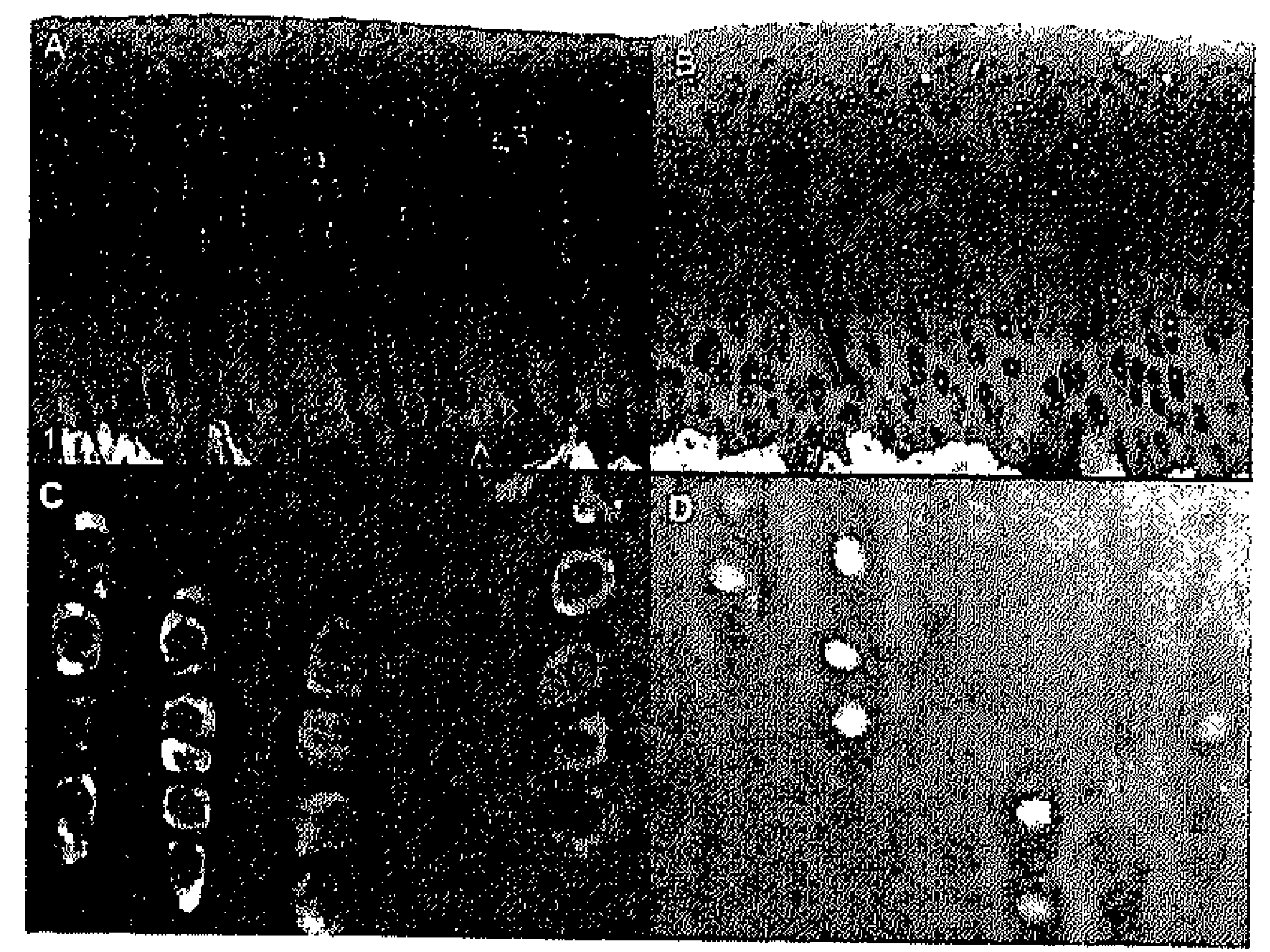

Figure 1: (A) Rabbit cartilage decalcified with $10 \%$ EDTA and stained with thionine. Note the intense matrix staining and the presence of nuclei. (B) Rabbit articular cartilage after decalcification with of the diluted TBD-1 solution and thionin staining. Note the weaker matrix staining and the absence of nuclei.. (C and D) Enlargements of $(A)$ and $(B)$, respectively. A and B, X 50; C and D, X 400 .

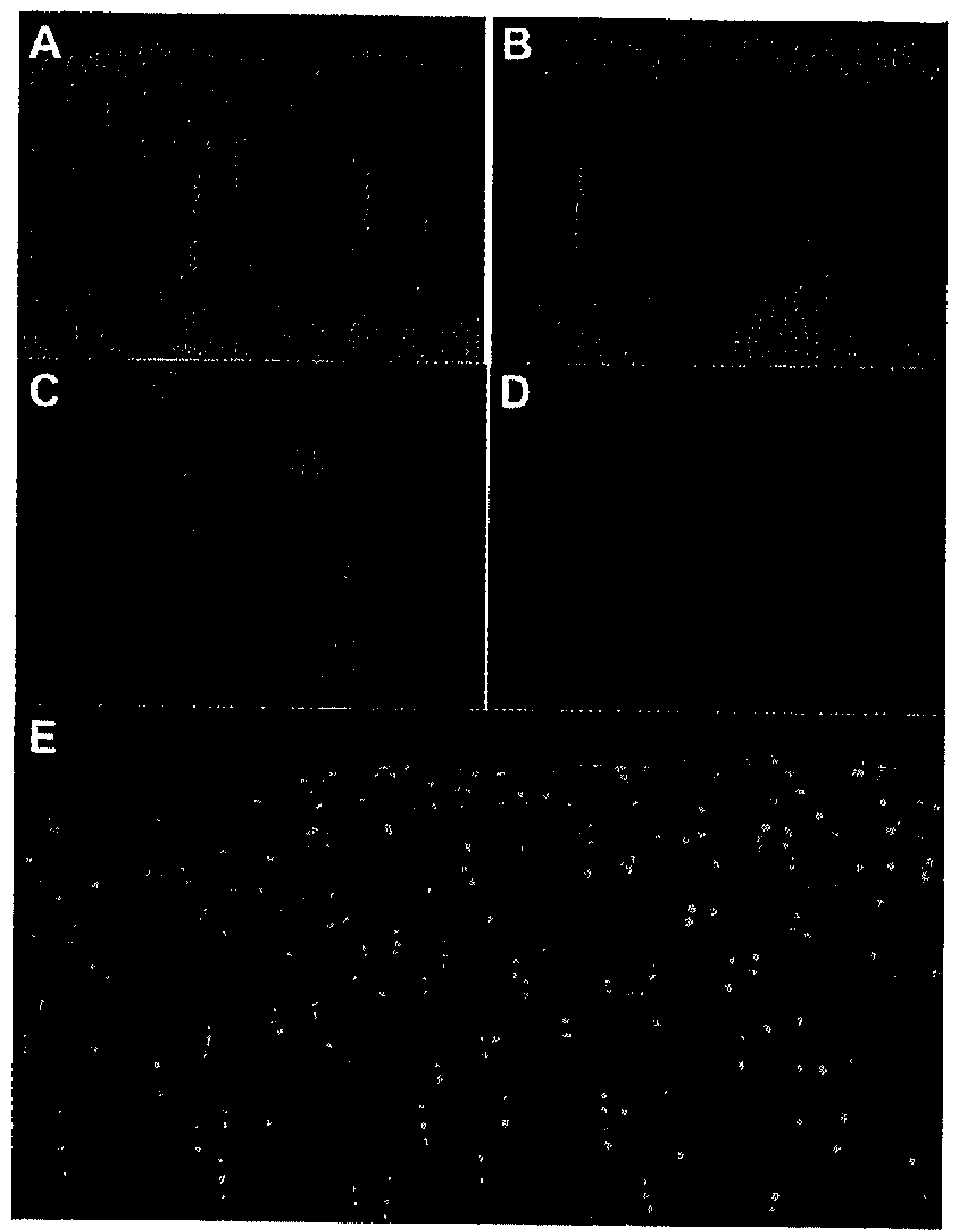

Figure 2: (A) Rabbit cartilage decalcified with $10 \%$ EDTA and stained with DAPI. Note the retention of DNA. (B) Rabbit cartilage after decalcification with of the diluted TBD-1 solution and DAPI staining. Note the loss of DNA.(C and D) Enlargements of (A) and (B), respectively. (E) Rabbit articular cartilage after decalcification with $10 \%$ EDTA and incubation with DNAse and TUNEL assay (positive control). $A$ and B X 50; C and D, X 400; E, X 100. 


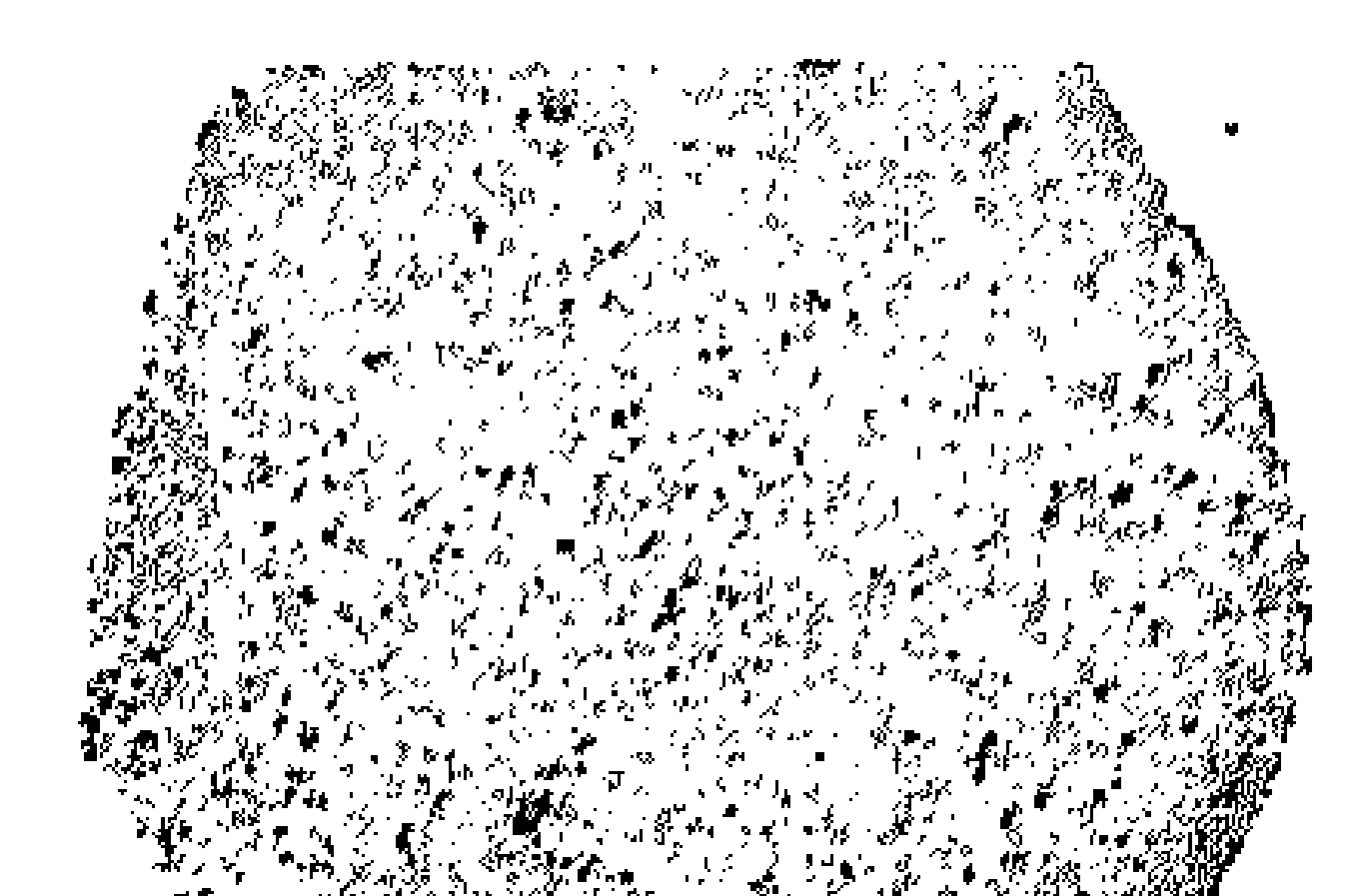

A

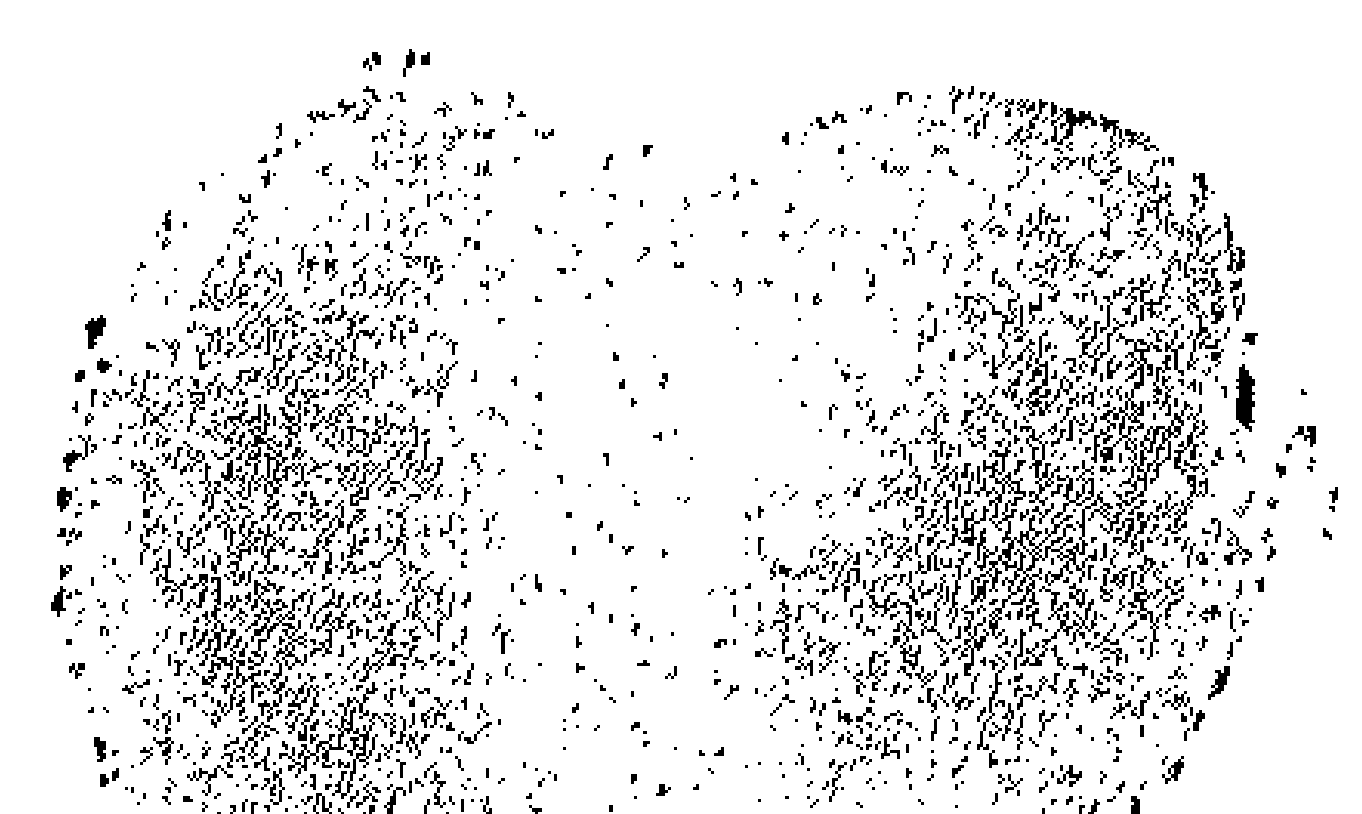

B

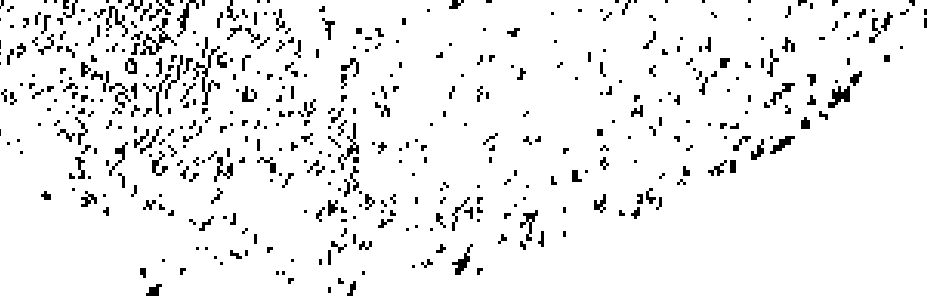

C

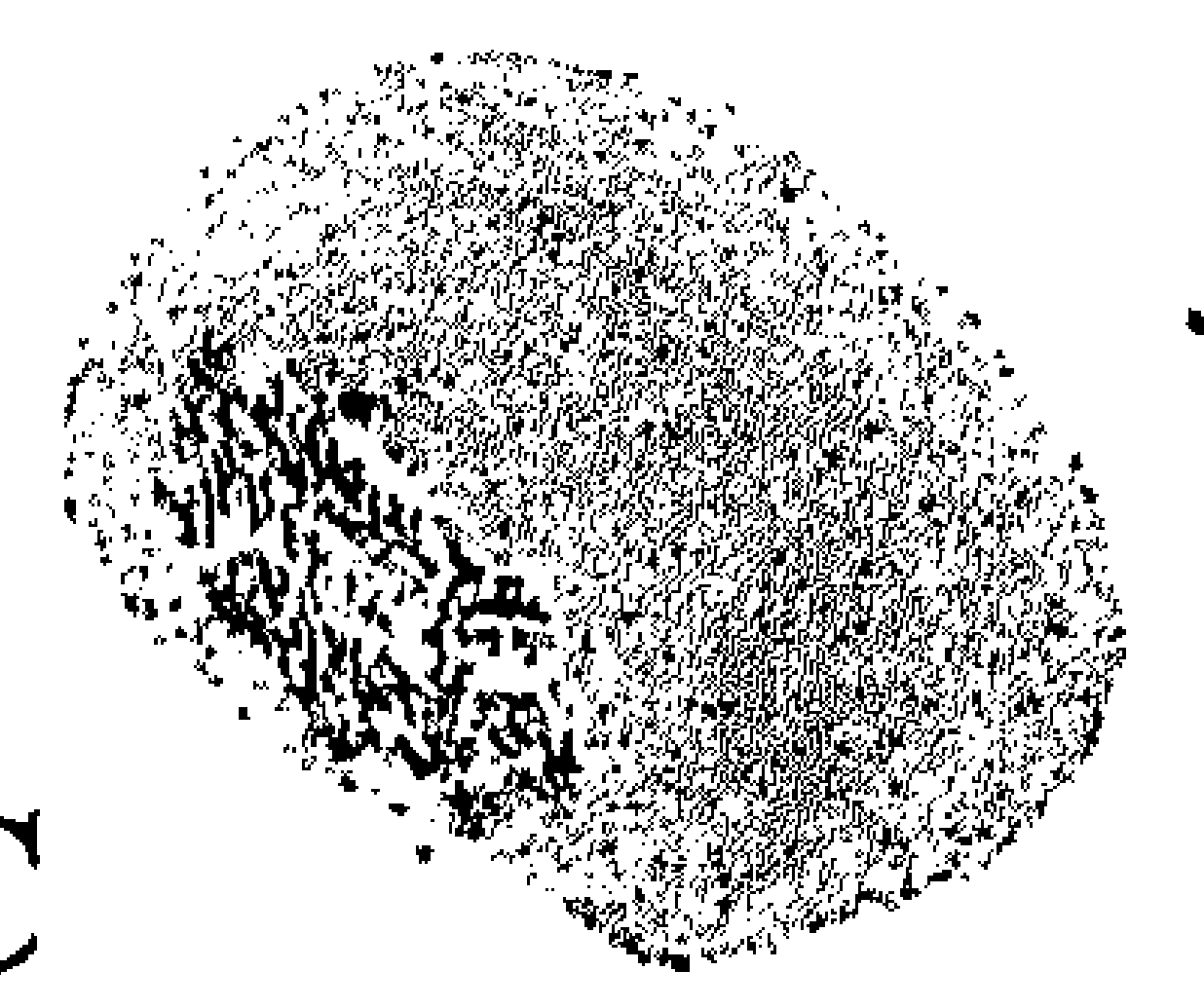

Figure 2. Micrographs of cryosections of micromasses after staining with Alcian blue (donor age was 62 years). Periosteal-derived cells were differentiated in medium $\mathbf{A}$ ) without growth factors or medium supplemented with B) TGF- $\beta_{1}(10 \mathrm{ng} / \mathrm{mL})$ or C) TGF- $\beta_{3}(10 \mathrm{ng} / \mathrm{mL})$. Notice the zone of calcification in the micromass that was differentiated with TGF- $\beta_{3}$. Magnification: $50 \mathrm{x}$.

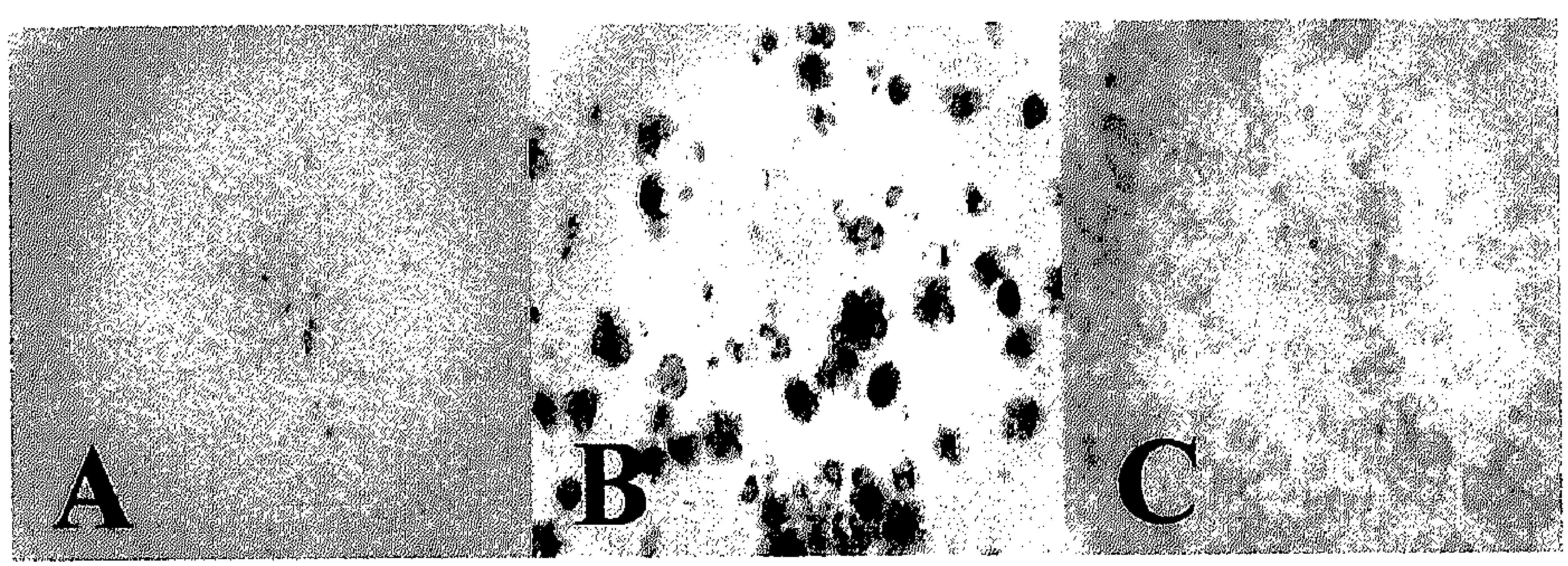

Figure 3. Micrographs of cytospins after immunocytochemical staining with antibodies A) M38; B) II-II6B3 and C) Thy-1 of periosteum-derived cells (donor age was 62 years). Differentiation medium was supplemented with TGF- $\beta_{3}$. Magnification 100x.

\section{CHAPTER 5}

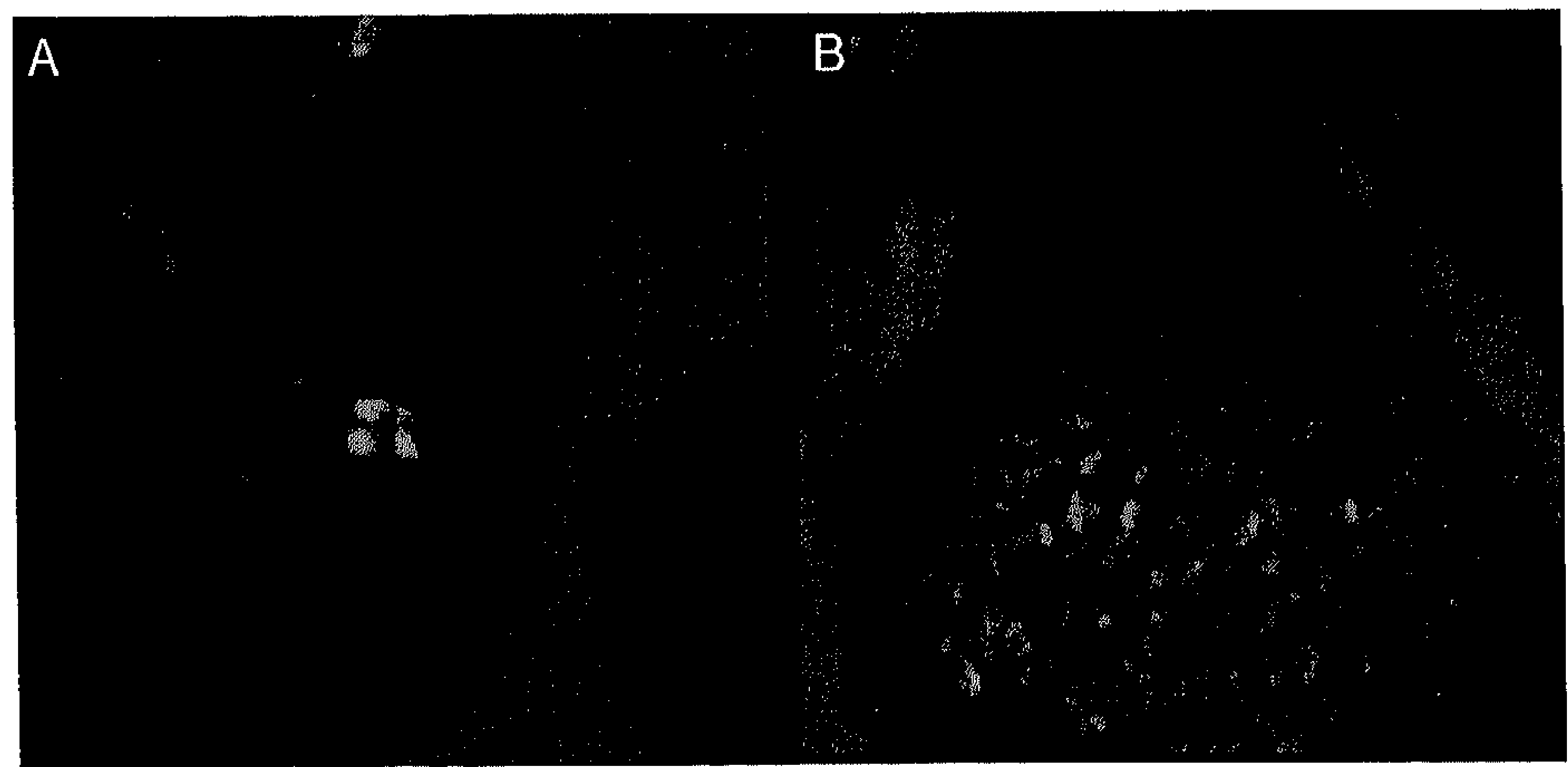

Figure 1. Fluorescence micrographs of CM-DiI (red) stained chondrocytes with a blue (DAPI) nucleus are considered viable. (A) The green nuclei are of nonviable CM-Dil labeled (red cell, right upper corner) and non-CM-DiI labeled cells. CM-Dil labeled cells without blue nuclei are also regarded non-viable. (B) A CM-DiI labeled chondrocyte cluster. Notice chondrocytes with and without blue nucleus. 


\section{CHAPTER 5}
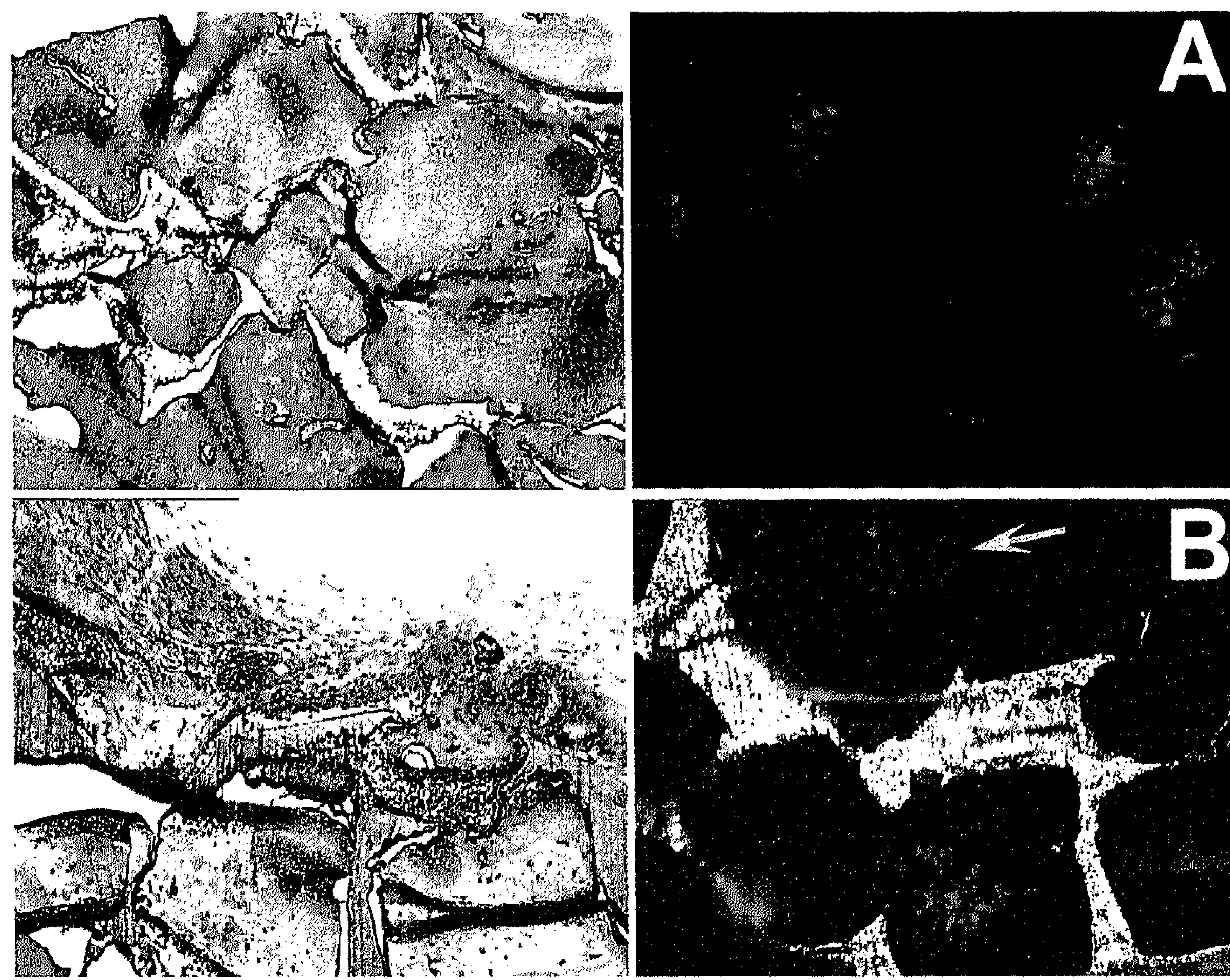

Figure 2. Consecutive GMA sections of compression molded PEGT/PBT polymer scaffolds seeded with CM-Dil labeled rabbit chondrocytes and implanted subcutaneously in a nude mouse. Notice correspondence between the fluorescent CM-DiI labeled chondrocytes clusters (left) and with the thionine stained chondrocytes (right) . (A) Five days post-implantation of viable rabbit chondrocytes, no label transfer was detected. (B) Implantation of devitalized rabbit chondrocytes; after seven days some evidence for label transfer was detected.

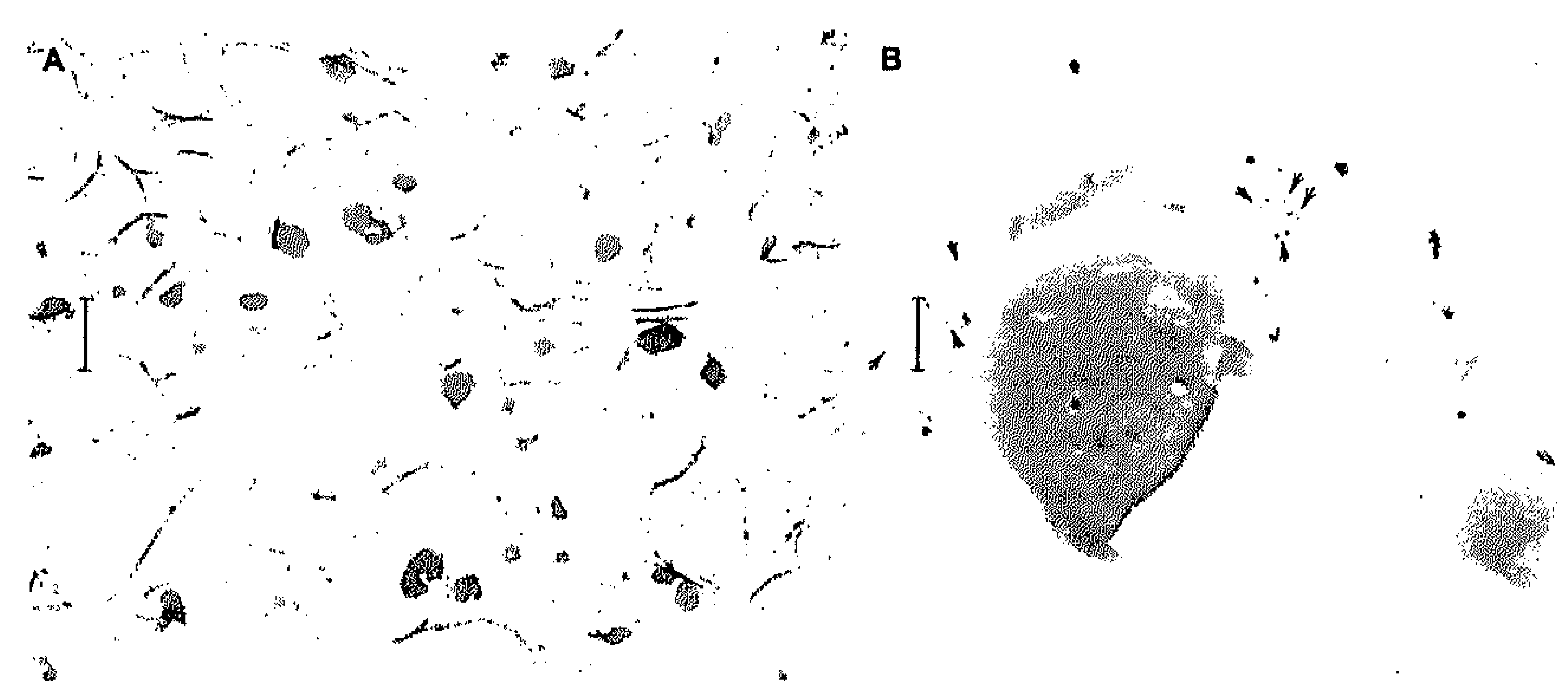

Figure 4. Photographs of a histological section of an explanted cell-scaffold constructs that contained chondrocytes, cultured for 2 weeks within the 3-D CM scaffold. Immediately after implantation, hyaluronan was injected in the knee joint. (A) Overview, showing cartilaginous 'islands' throughout the scaffold. Bar. $\sim 260 \mu \mathrm{m}$. (B) Detail showing apoptotic cells (arrows). Bar. $\sim 32 \mu \mathrm{m}$. 


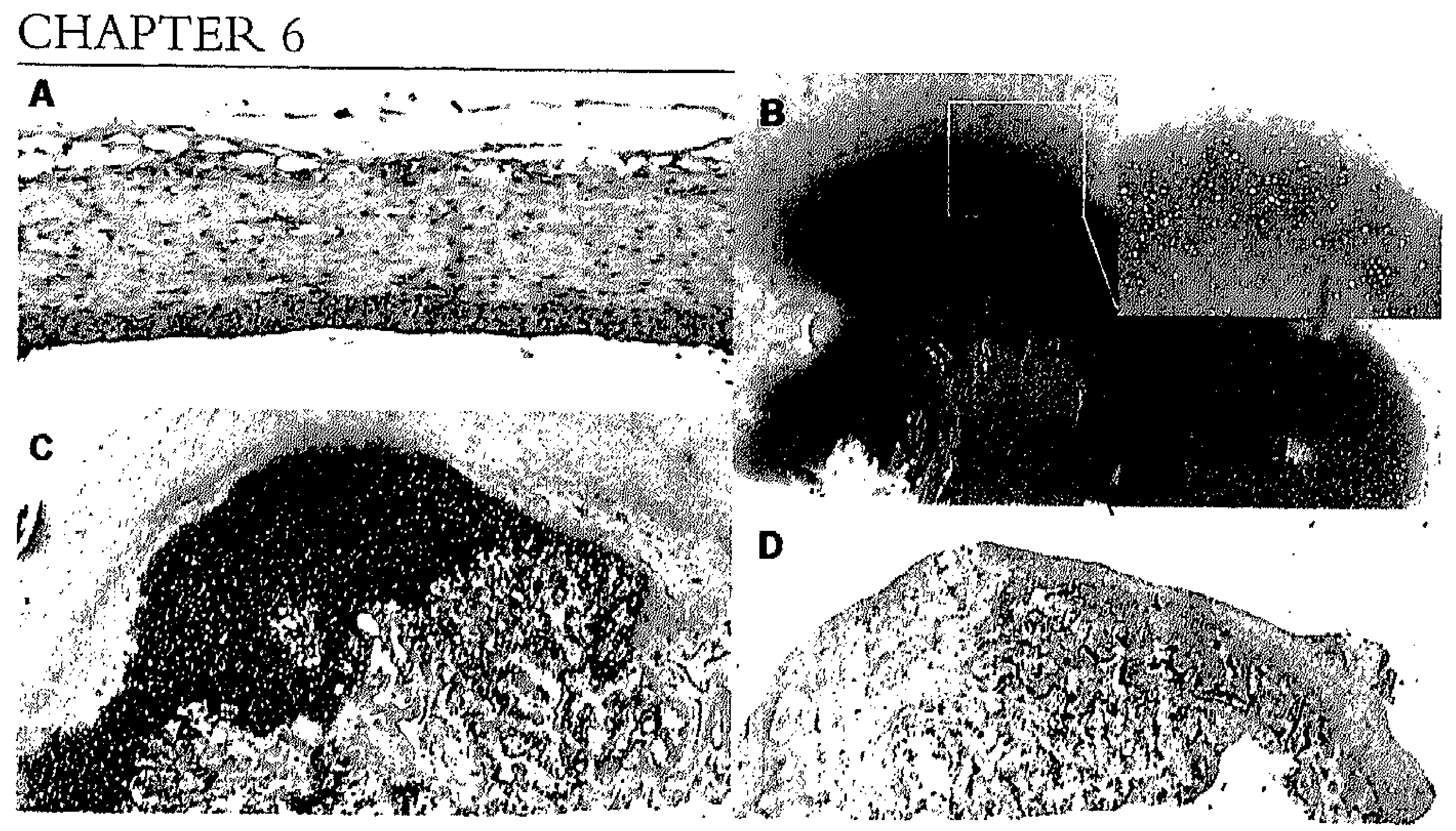

Figure 3. Histological sections stained with thionine. (A) Rabbit periosteum (day ()): note the (lower) cambium layer (B) Ten days postsurgery; a large piece of cartilage is differentiated from the cambium cells (see insert). (C) Twenty days postsurgery; numerous chondrocytes are hypertrophic. Bone and newly formed bone marrow are seen. (D) Forty days post-surgery; the cartilage is almost completely differentiated into bone, remnants of the cartilage matrix still being visible. Original magnification (A) $\times 100:(B) \times 16:$ (C) X16; insert in (B). X 100

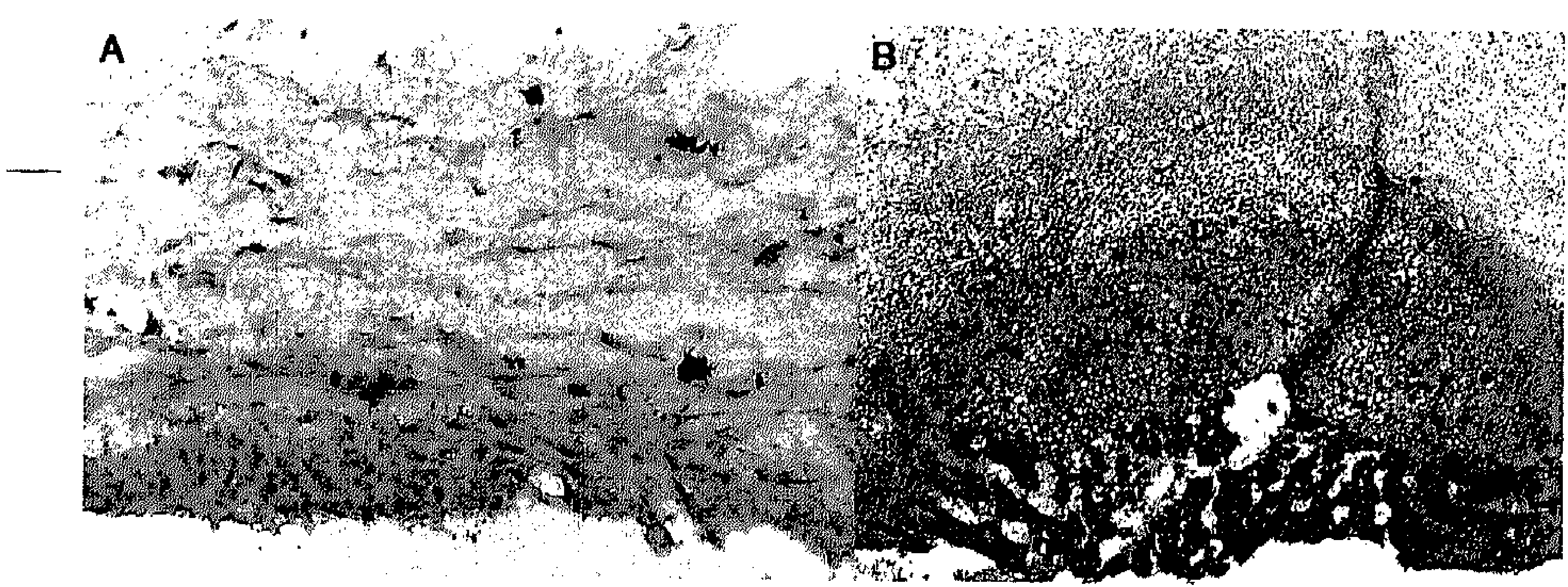

Figure 6. Histological sections stained for the presence of alkaline phosphatase activity. (A) endogenous Alkaline Phosphatase (ALP) in the cambium layer of periosteum. (B) Intense staining for endogenous ALP in bone, less staining intensity in hypertrophic chondrocytes, and absence of ALP activity in young chondrocytes. Original magnification: (A) X 400; (B) X 50. 


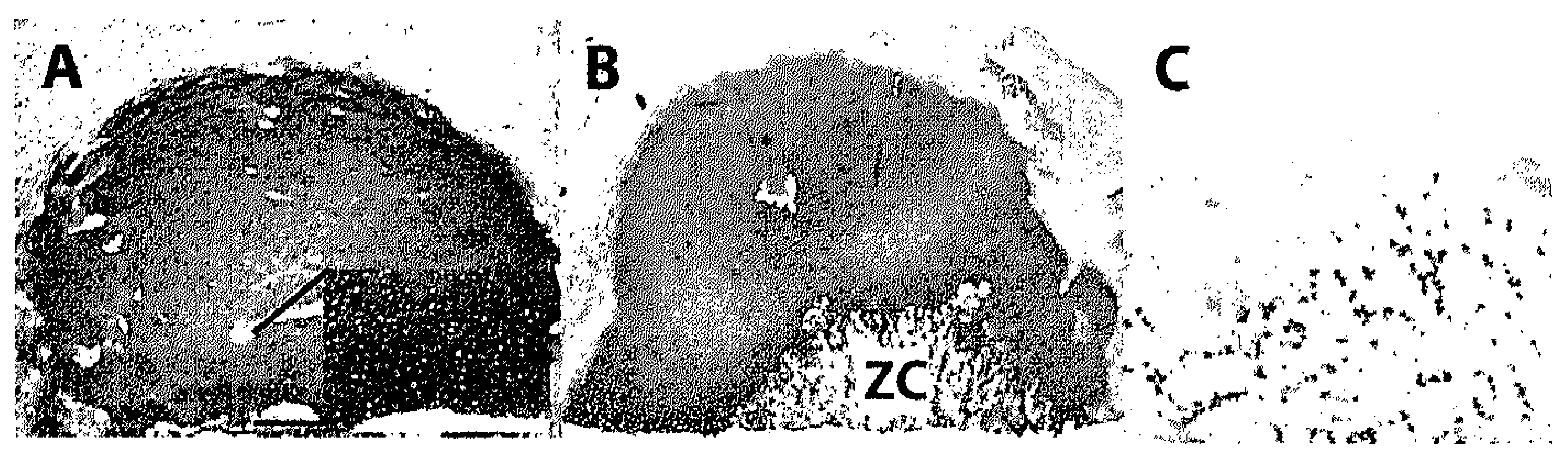

Figure 2. Immunohistochemical detection of Collagen Type II in periosteal reactive tissue (callus); (A) 10 days post-surgery this, collagen is present in the newly formed cartilage (a thionine stained section is enlarged). (B) At twenty days post-surgery the presence of Collagen Type II decreases at the zone of calcification (ZC) and bone formation. (C) 40 days post-surgery, remnants of Collagen Type II are still visible (brown). Sections counterstained with hematoxylin. Original magnification (A) X16; (B) X16; (C) X16; insert in (A) X100.

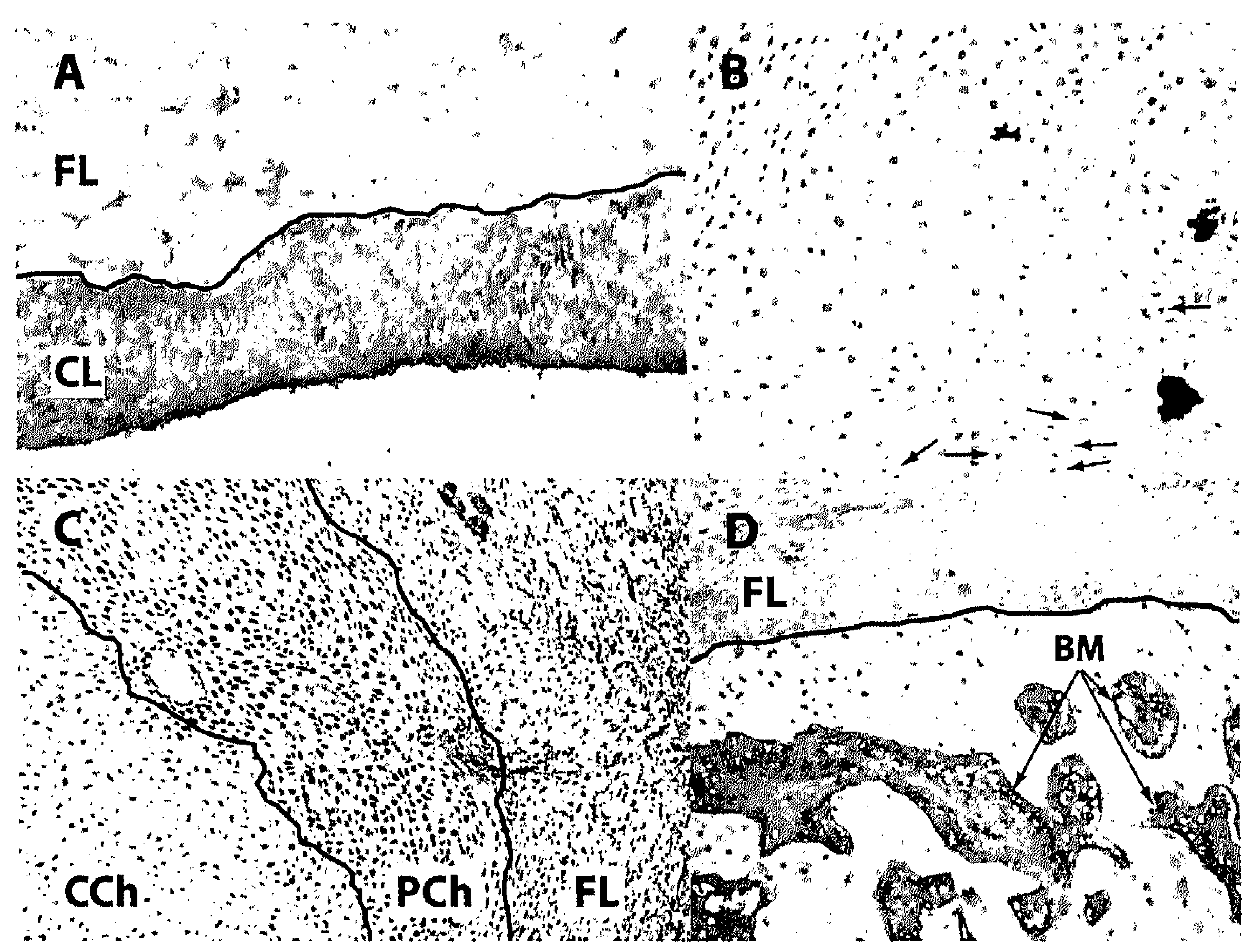

Figure 3. Immunohistochemical detection of Periostin/POSTN in periosteum. (A) POSTN is detected (brown colour) especially in the cambium layer (CL) but is also found in the fibrous layer (FL) of periosteum. (C) 10 days post-surgery the number of POSTN-positive cells is higher in the peripheral chondrocytes $(\mathrm{PCh})$ compared to the chondrocytes localized centrally (CCh). (D) 40 days post-surgery, POSTN is present in the newly formed bone marrow (BM). (B) Immunohistochemical staining of HIF-1 $\alpha$ shows its presence (red) in chondrocytes 10 days postsurgery, no HIF-1 $\alpha$ staining is found in hypertrophic chondrocytes (arrows). Original magnification (A) X200; (B) X200; (C) X200; (D) X200. 
150 CHAPTER 7

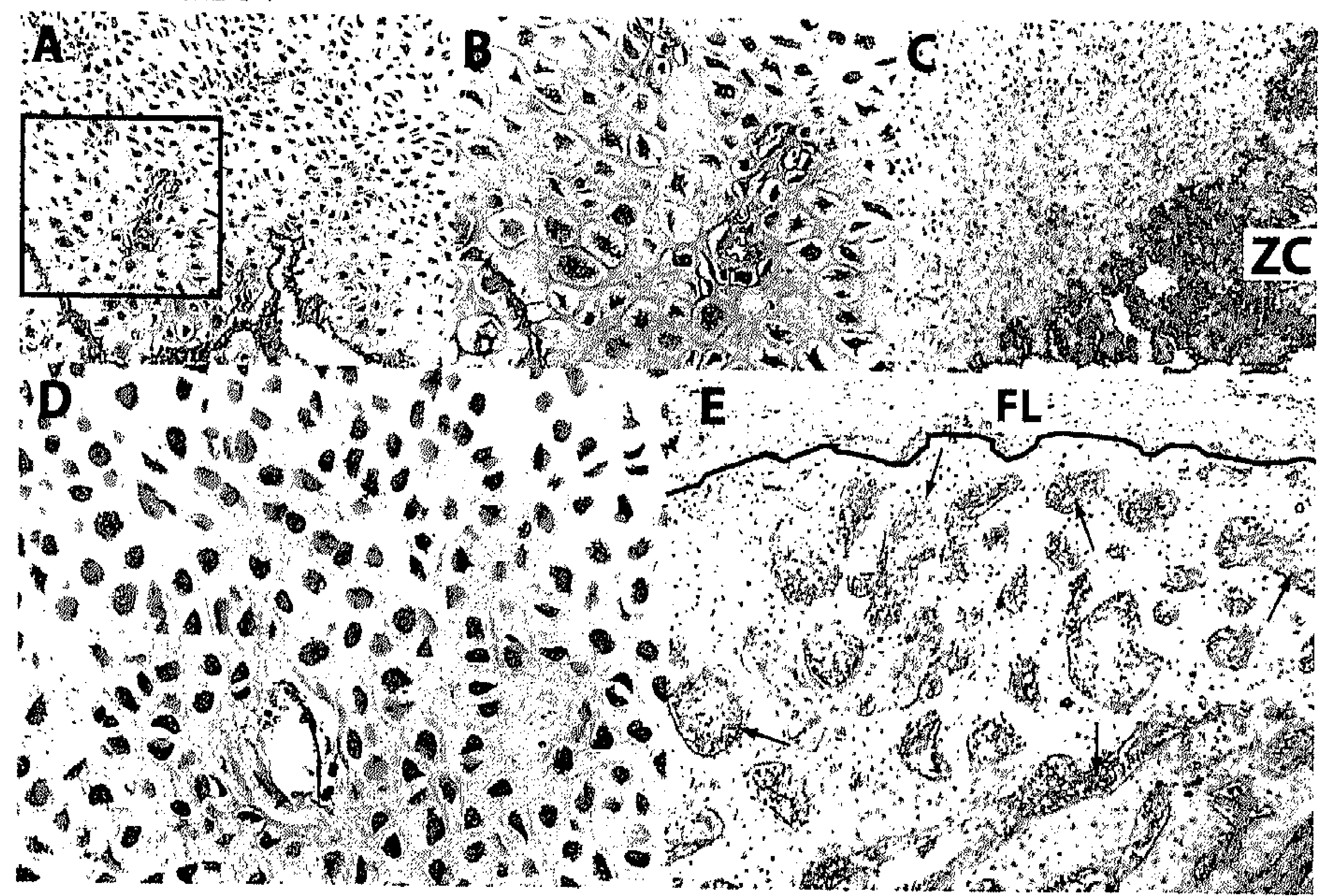

Figure 4. Immunohistochemical detection of BMP-4 in periosteal callus; (A) 10 days postsurgery, chondrocytes stain positive (red) for BMP-4. (B) is an enlargement of the box in (A). (C) 20 days post-surgery, BMP-4 is neither detccted in chondrocytes nor in the zone of calcification (ZC). Sections counterstained with hematoxylin. Immunohistochemical detection of BMP-2 in periosteal callus; (D) 10 days post-surgery, chondrocytes stain positive (red) for BMP-2. (E) 40 days post-surgery, BMP-2 is detected in the newly formed bone marrow (arrows), the overlying fibrous layer is indicated with FL. Original magnification (A) X200; (B) X400; (C) X200; (D) $\mathrm{X} 400$; (E) X100. 
CHAPTER 8
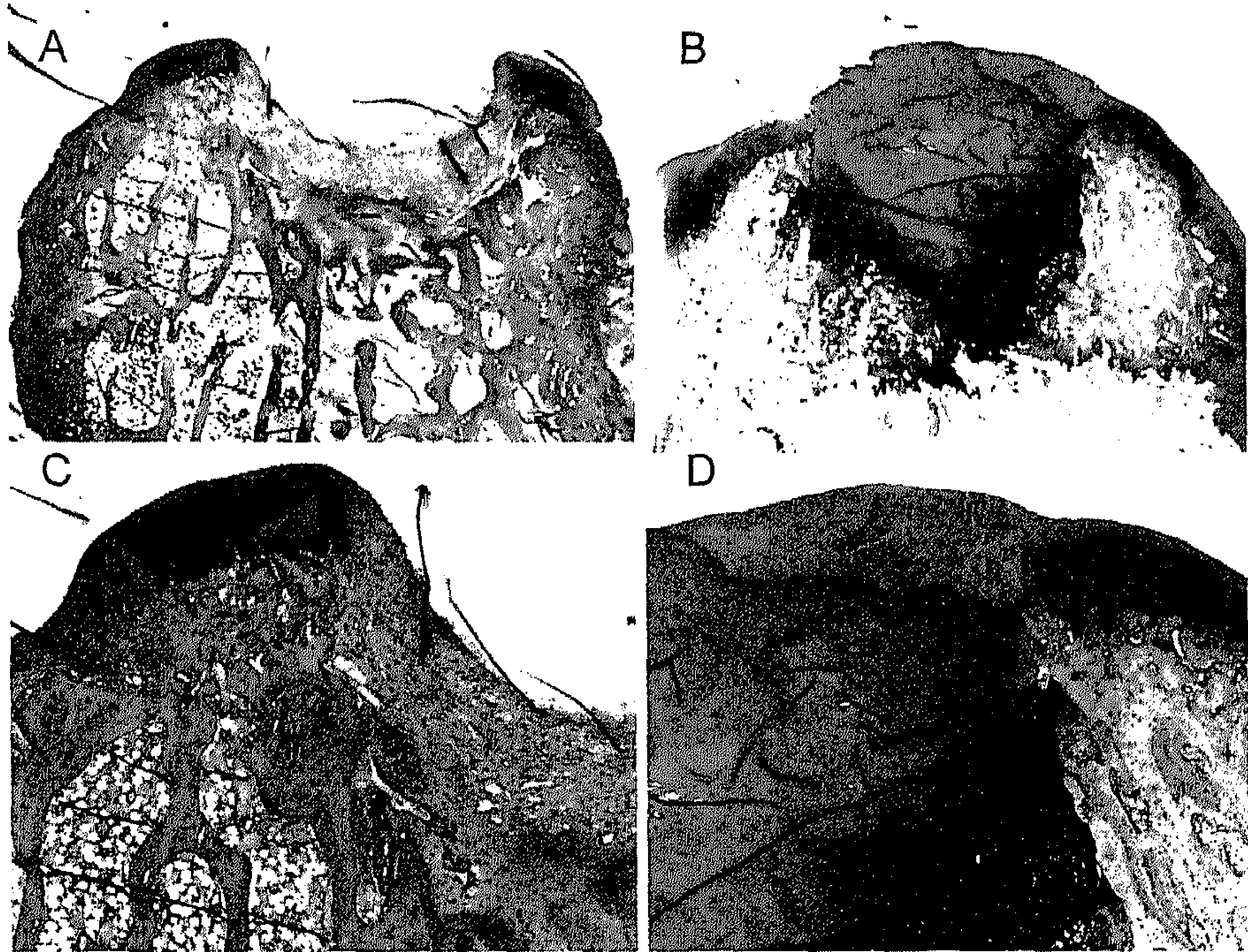

E
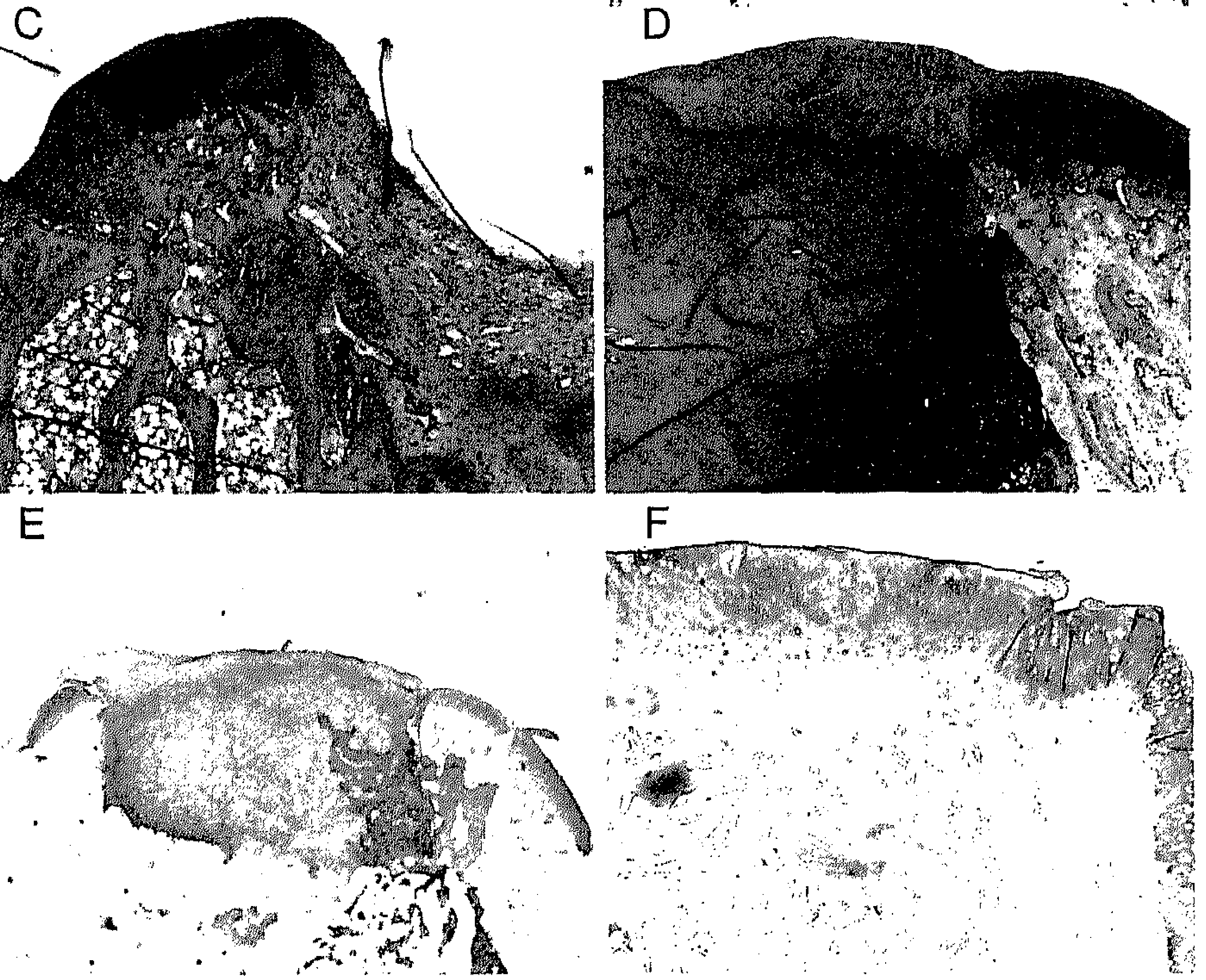

Figure 3: (A) Thionine staining of an empty osteochondral defect at 3 weeks, treated with HYA. (B) Thionine staining of an osteochondral defect in which ectopic cartilage (no HYA) has been implanted. The joint surface level was restored, the graft appeared viable, and good tissue ingrowth was observed. (C) Enlargement of (A) showing the initial repair with fibrous tissue with some macrophages. (D) Enlargement of (B) showing a proper integration of the graft and the original tissue. (E) Section of a grafted defect with HYA at 3 weeks, stained with a Collagen Type II antibody. (F) Section of a grafted defect at 3 months, stained with a Collagen Type II antibody. Original magnification: (A, B, and E) X 16; (C and D) X 50; (F) X 40 . 
152 | CHAPTER 8

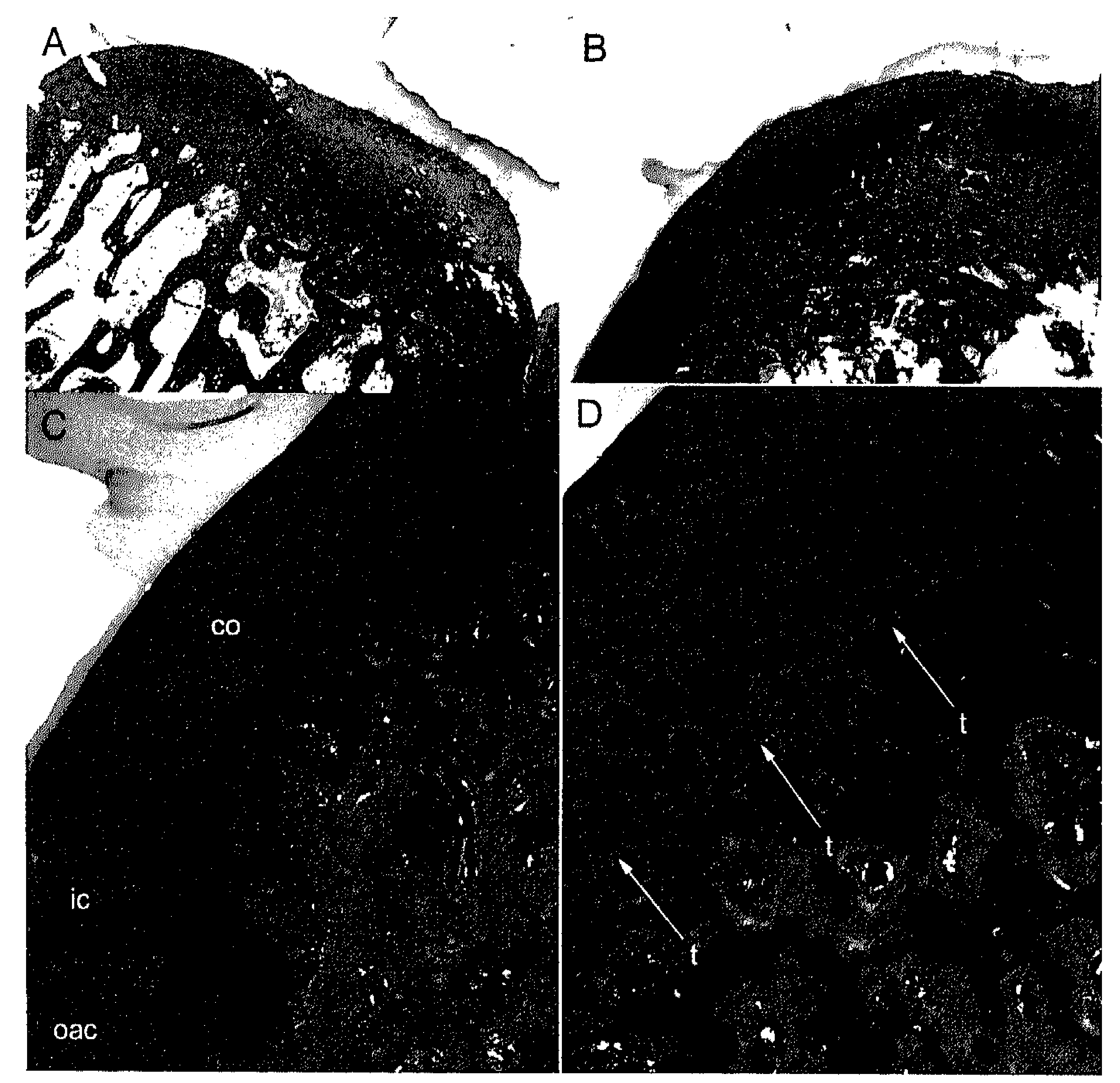

Figure 4: (A) Section of an empty defect plus HYA at 3 months, stained with thionine. The defect was partially filled with fibrous tissue. (B) Section of a grafted defect plus HYA at 3 months, stained with thionine. Good ingrowth in the adjacent cartilage was observed. The newly formed subchondral bone protrudes slightly. (C) Higher magnification of (B), illustrating a 'hyalin cartilage-like' orientation of the chondrocytes (co). The implanted cartilage (ic) shows a good ingrowth in the original articular cartilage (oac); (D) Higher magnification of (B), illustrating the presence of a tidenark $(t)$, indicated with arrows. Original magnification: (A and $B$ ) X 16; (C) X 100 ; (D) X 200. 


\section{Dankwoord}

Zonder de hulp van velen zou dit proefschrift nooit tot stand zijn gekomen. Bij deze wil ik iedereen bedanken die mij gesteund heeft en met warmte de ontwikkelingen rond dit proefschrift heeft gevolgd.

Allereerst mijn ouders en zussen; pap, mam, Mireille en Annelies jullie vertrouwen en steun is essentieel, niet alleen voor dit proefschrift maar voor veel dingen in mijn leven.

De promotoren, Prof. dr. RG.T Geesink en Prof. dr. S.K. Bulstra dank ik voor de mogelijkheid die ze mij gegeven hebben voor het doen van onderzoek. Ruud, als student-assistent ben ik bij jou begonnen met onderzoek. Zowel opereren als overleg met je lijkt op de schilderlessen van Bob Ross; rustig opbouwend commentaar, alles lijkt verraderlijk makkelijk en het resultaat is prachtig. Sjoerd, je ideeën en enthousiasme lijken wel oneindig. Met name jouw inzet en geregel achter de coulissen waren essentieel voor dit proefschrift, hartstikke bedankt hiervoor!!! Helaas zijn of gaan jullie weg uit Maastricht, toch hoop ik dat we elkaar nog vaak tegen komen.

De co-promotores, dr. R. Kuijer en dr. L.W.van Rhijn. Roel, je kennis en kunde op basaal en klinisch onderzoeksgebied is enorm groot. Zonder jouw steun en begeleiding zou dit proefschrift niet tot stand zijn gekomen. Jij hebt me geïntroduceerd in de wereld van basaal orthopaedisch onderzoek en vaak kwamen we samen enthousiast terug van enerverende meetings, bedankt hiervoor!!! Lodewijk, jouw betrokkenheid bij het lab en overredingskracht bij het schrijven van een subsidieaanvraag is fenomenaal. Ik zie er naar uit om nog veel van je te leren.

De leden van de beoordelingscommissie, met Prof. dr. ir. L.H. Koole als voorzitter, bedank ik voor het doornemen van dit proefschrift en de daarbij getoonde belangstelling.

De staf, assistenten en trialbureau orthopaedie, bedankt. André, als opleider en die me de tip gaf om bij Ruud onderzoek te doen, Geert, Henk, René, Mike, Patrick, Carlinde, Ruud, Lodewijk en assistenten bedankt voor de gezellige en leerzame tijd. Ook iedereen van het secretariaat, de poli, afdeling, OK en SEH bedankt. 
Don en Edwin, paranimfen. Ik ben vereerd dat jullie naast me zullen staan. Don, jouw inzet en kennis is van groot belang voor het lab en dit proefschrift. Ik bewonder de rust, de kunde (gouden handen) en het optimisme waarmee je mij en velen begeleidt hebt in de wereld van allerhande laboratoriumtechnieken. Edwin, niet alleen als AGIKO maar in meerdere opzichten ben je voor mij een voorbeeld, bedankt voor je bijdrage aan dit proefschrift!!!

Uiteraard ben ik door velen van het Orthopaedisch laboratorium geholpen. Tim, je bent net gestart als post-doc en nu al ben je vol enthousiasme op de hoogte van "periostéum" en kraakbeen, ik ben erg blij dat je er bent. Andy, als student begonnen en nu als vaste kracht steun en toeverlaat voor andere studenten. Wendy, Martine, Eric, Keryn en Nina, bedankt voor jullie inzet en gezelligheid natuurlijk!!!

En dan de mensen met de chemie in letterlijke en figuurlijke zin, Willem en Frank. Willem zonder jou zou het orthopaedie lab niet dit niveau bereikt hebben en wellicht zelfs niet hebben kunnen voortbestaan. Ik ken maar weinig mensen met jouw snelheid van denken.

Frank, zowel op praktisch als theoretisch niveau heb je ons erg gesteund. Ik hoop dat de chemie tussen onze vakgroepen blijft bestaan.

De vakgroep biomaterialen; Leo, Tosca, Erik, Rachel, Ketie, Menno en Yvette, we hebben in het verleden op allerlei gebieden samengewerkt en ook de nodige ontspannen momenten gehad. Ik zie er naar uit om in de toekomst nog veel samen te doen.

De vakgroep anatomie wil ik bedanken voor alle ondersteuning en de mogelijkheden die ze mij geboden hebben op technisch gebied. Henk, Hennie, Els, Johan en Paul enorm bedankt!!

De staf en assistenten van de heelkunde in het AZM (Prof. dr. M.J.H.M. Jacobs als hoofd en Prof. dr. J.W.M. Greve en Dr. C.H.C Dejong als opleiders), iedereen van harte bedankt voor het bijbrengen van een solide chirurgische basis, ik heb een enorme leerzame en plezierige tijd gehad bij jullie!!!

De partners van het BTS programma; "Finding novell cell sources for cartilage tissue engineering", IsoTis N.V. en de afdeling Orthopaedie van het Erasmus Medisch Centrum in Rotterdam. Jens, Jeroen, Mireille, Ellen, Gerjo, Erik, Jarno en Justus (hustler bar) bedankt voor de brainstormsessies en de gezellige bijeenkomsten. 
Prasad Shastri, independent of each other we believed in the concept of using periosteum in vivo for generation of cartilage or bone. In the short time we know each other we have already achieved a lot of things and I am enthousiastic and looking forward to all the things to be planned.

Alle mensen van de proefdierenvoorziening, met name de mensen van "groot"; Joyce, Petra, Noortje, May, Frans, Monique en Marion wil ik bedanken voor hun inzet en ondersteuning. Ook de onderzoekers van de onderzoeksgroep fysiologie wil ik bedanken voor het beschikbaar stellen van het konijnenperiost.

Met de "de Source", amigos de la boda, PHC'ers en het roeiteam heb ik ongelooflijke momenten meegemaakt. Bedankt voor alle inspiratie en ontspanning!!!

Allerliefste Lonneke, nooit gedacht dat iemand zoals jou zou bestaan. We hebben het samen ongeloollijk goed en ik ben nog hartstikke verliefd op je!!! Tegen de tijd dat ik dit proefschrift moet verdedigen is ons kleintje geboren en ik verheug me op onze toekomst samen.

Pieter J. Emans

"goed leren jongen"

opa Emans 


\section{Curriculum Vitae}

Pieter Emans was born in Weert, the Netherlands on September the 20th 1974. After he finished from Bisschoppelijk College Weert (high school) he attended Medical School at the University Maastricht in 1994 and graduated in September 2000. As a medical student he performed an internship Orthopaedic Surgery at the university hospital "Haddassah", Jerusalem, Israel, an internship liver transplantation surgery at hospital "La Paz" in Madrid Spain and an internship Primary Health Care (PHC) at the UAM, Mexico City, Mexico.

Before starting in 2002 as a $\mathrm{PhD}-$ student at the department of Orthopaedic Surgery in Maastricht, he worked at the University Hospital Maastricht and Maasland Ziekenhuis Sittard as a resident Orthopaedic Surgery. He was nominated for the Pelerin Prize in 2004 and won the Goran Bauer Grant in 2006. In January 2004 he started his training as a surgical resident at the Department of Surgery, University Hospital Maastricht (Prof. dr. M.J.H.M. Jacobs, Prof. dr. J.W.M. Greve and Dr. C.H.C Dejong). In January 2006 he continued his residency at the department of Orthopaedic Surgery, University Hospital Maastricht (Prof.dr. R.G.T. Geesink and Dr. A. van Ooy). 


\section{Publications}

A Novel in vivo Model to study endochondral bone formation; HIF$1 \alpha$ activation and BMP expression. Pieter J. Enans, Frank Spaapen, Don AM. Surtel, Andy Cremers, Keryn M. Reilly, Martine M. Hulsbosch, Sjoerd K. Bulstra, Willem J. Voncken, Roel Kuijer. Bone. 2007 Feb;40(2):409-18

Differential cell viability of chondrocytes and progenitor cells in tissue engineered constructs following implantation into osteochondral defects. Emans, P.J., Pieper, J., Hulsbosch, M., Koenders, M., Kreijveld, E., Surtel, D.A.M., van Blitterswijk C.A., Bulstra, S.K., Kuijer, R, Riesle J. Tissue Eng. 2006 Jun; 12(6):1699-709.

Comparison of two hydroxyapatite-coated femoral stems clinical, functional, and bone densitometry evaluation of patients randomized to a regular or modified hydroxyapatite-coated stem aimed at proximal fixation. Sluimer J.C., Hoefnagels N.H.M., Emans P.J., Geesink R.G.T.J Arthroplasty. 2006 Apr;21(3):344-52

The Currarino triad; neurosurgical considerations. Emans P.J., van Aalst J., van Heurn L.W.E., Marcelis C., Kootstra G., Vles J., Beuls E.J. Neurosurgery. 2006 May;58(5):924-9.

De posterieure toegang bij de posteromediale tibiaplateau luxatie fractuur. Pieter J. Emans, Stefan van Zutphen, Peter R.G. Brink. Nederlands Tijdschrift voor Traumatologie feb. 2006.

Repair of osteochondral defects in rabbits with ectopically produced cartilage. Emans P.J. Hulsbosch M, Wetzels G.M.R. Bulstra S.K., Kuijer R. Tissue Eng. 2005 Nov-Dec;11(11-12):1789-96

The Currarino triad: the variable expression. Enans, P.J., Kootstra, G., Marcelis, C., Beuls, E.A.M., van Heurn, L.W.E. J Pediatr Surg. 2005 Aug; 40(8):1238-42.

The effects of different decalcification protocols on TUNEL and general cartilage staining. Emans P.J., Bulstra S.K., Kuijer R. Biotech Histochem. 2005 May-Aug;80(3):111-5. 
Biocompatibility of novel iodine containing microspheres. Emans, P. J. Saralidze, K., Knetsch, M.L., Aldenhoff, Y.B., Kuijer, R., Koole, L.H.J Biomed Mater Res A. 2005 Jun 15;73(4):430-6.

In Vivo Generation of Cartilage out of Periosteum. Emans, P.J.,Surtel, D.A.M., Frings, E.J.J., Reilly, K.M., Bulstra, S.K., Kuijer, R. Tissue Eng. 2005 Mar-Apr;11(3-4):369-77.

Variable chondrogenesis of aged human periosteal cells; effects of growth factors on proliferation and differentiation. Edwin JP Jansen, Pieter J Emans, Martine M Hulsbosch, Mireille Schrooten-van Helden, Don AM Surtel, Sjoerd K Bulstra, Roel Kuijer. 2007; Submitted.

Effect of one injection hyaluronan on injured articular cartilage in rabbit knees. Edwin J.P. Jansen, Pieter J. Emans, Conny M. Douw, Nick A. Guldemond, Lodewijk W. Van Rhijn, Sjoerd K. Bulstra, Roel Kuijer. 2007; Submitted.

Long - term results of HA - Coated THA in patients younger than 50 years of age; PE wear correlates with acetabular osteolysis. Pieter $J$. Emans, Jeroen M.J. van Mulken, Roel Kuijer, Rudolph G.T. Geesink. 2007; Submitted. 